Prepared in cooperation with the U.S. Army Corps of Engineers

\title{
A Markov-Chain Analysis of the Movements of Juvenile Salmonids, Including Sockeye Salmon, in the Forebay of McNary Dam, 2006-09
}

Open-File Report 2012-1120 



\section{A Markov Chain Analysis of the Movements of Juvenile Salmonids, Including Sockeye Salmon, in the Forebay of McNary Dam, Washington and Oregon, 2006-09}

By Noah S. Adams and Tyson W. Hatton

Prepared in cooperation with the U.S. Army Corps of Engineers

Open-File Report 2012-1120 


\section{U.S. Department of the Interior \\ KEN SALAZAR, Secretary}

\section{U.S. Geological Survey \\ Marcia K. McNutt, Director}

U.S. Geological Survey, Reston, Virginia: 2012

For more information on the USGS-the Federal source for science about the Earth, its natural and living resources, natural hazards, and the environment, visit http://www.usgs.gov or call 1-888-ASK-USGS.

For an overview of USGS information products, including maps, imagery, and publications, visit http://www.usgs.gov/pubprod

To order this and other USGS information products, visit http://store.usgs.gov

Suggested citation:

Adams, N.S., and Hatton, T.W., 2012, A Markov chain analysis of the movements of juvenile salmonids, including sockeye salmon, in the forebay of McNary Dam, Washington and Oregon, 2006-09: U.S. Geological Survey Open-File Report 2012-1120, 104 p.

Any use of trade, product, or firm names is for descriptive purposes only and does not imply endorsement by the U.S. Government.

Although this report is in the public domain, permission must be secured from the individual copyright owners to reproduce any copyrighted material contained within this report. 


\section{Contents}

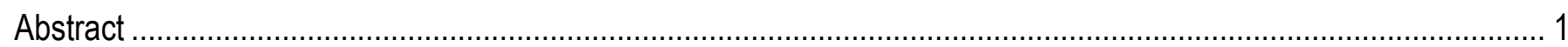

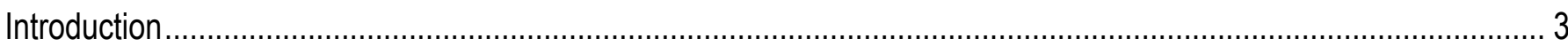

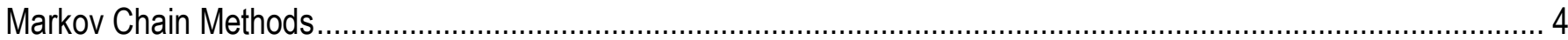

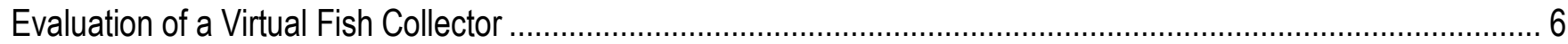

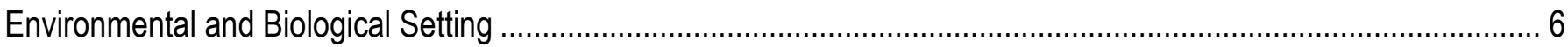

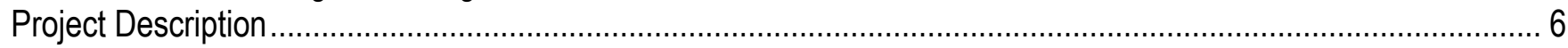

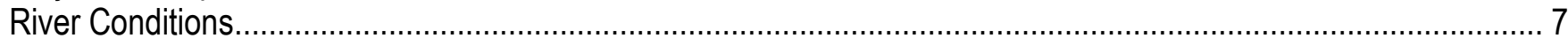

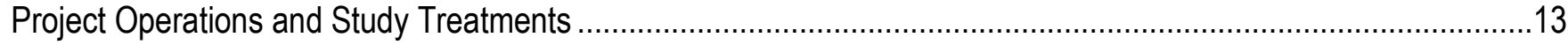

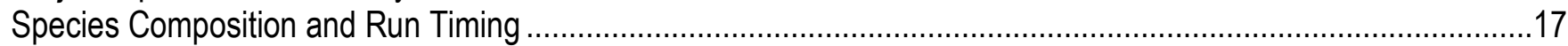

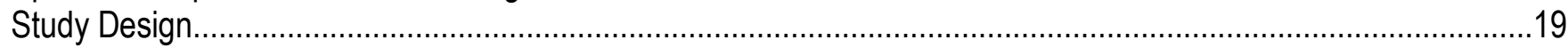

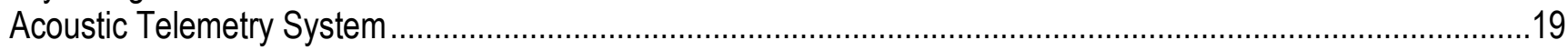

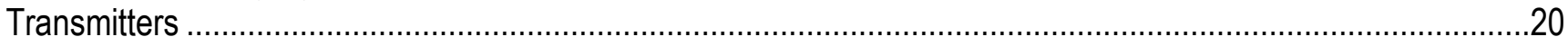

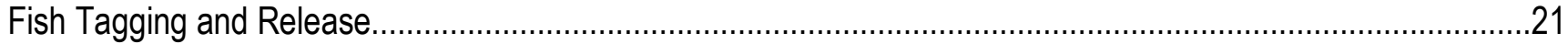

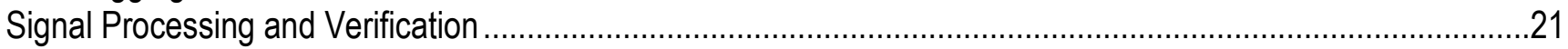

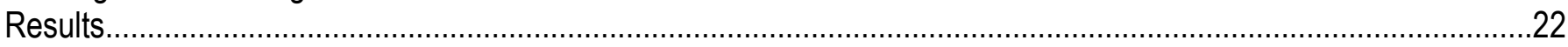

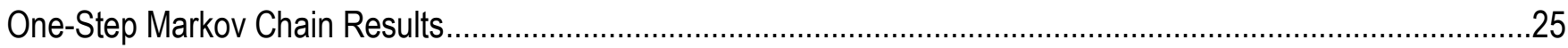

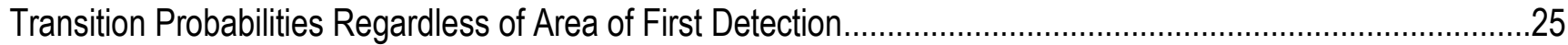

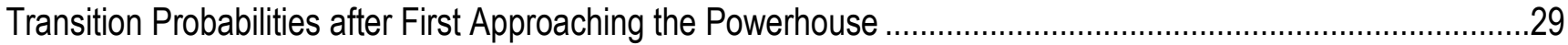

Transition Probabilities after First Approaching the Spillway …………………………………………......33

Transition Probabilities during Day and Night for Fish that First Approached the Powerhouse ............................36

Transition Probabilities during Day and Night for Fish that First Approached the Spillway..................................39

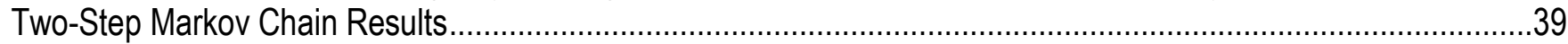

Transition Probabilities Regardless of where Fish First Approached the Dam ...............................................47

Transition Probabilities after First Approaching the Powerhouse ……………..............................................51

Transition Probabilities after First Approaching the Spillway …….............................................................54

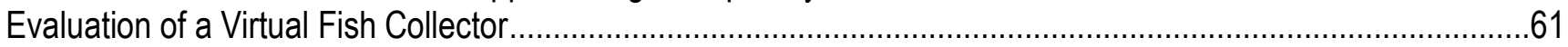

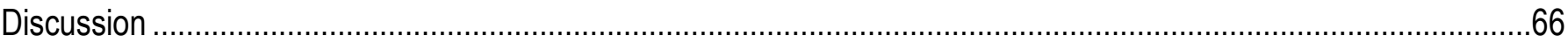

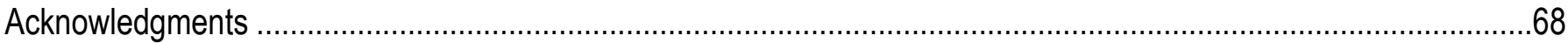

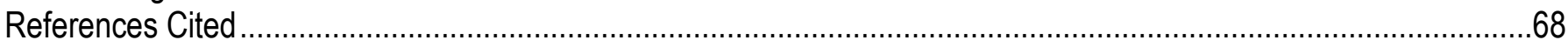

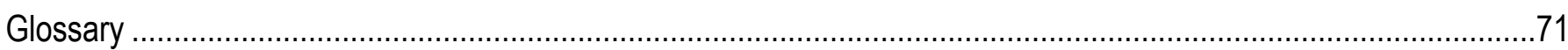

Appendix A. Locations of Hydrophones in the McNary Dam Forebay, 2006-09. ….............................................72

Appendix B: Results from the 2006 to 2009 one-step Markov chain analysis for all fish regardless of where they first approached the dam during the day and night periods.................................................................................77

Appendix C: Results from the 2006 to 2009 two-step Markov chain analysis for all fish regardless of where they first approached the dam during the day and night periods.

Appendix D: Results from the 2006 to 2009 two-step Markov chain analysis for all fish that first approached the powerhouse during the day and night periods.

Appendix E: Results from the 2006 to 2009 two-step Markov chain analysis for all fish that first approached the spillway during the day and night periods. 


\section{Figures}

Figure 1. Graphical representation of the upstream face of McNary Dam showing the powerhouse (left) and spillway (right).

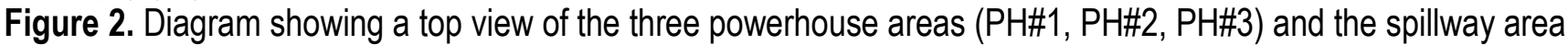
upstream of McNary Dam used in the Markov chain analysis

Figure 3. Map showing Columbia and Snake Rivers and the location of McNary Dam relative to other major hydroelectric projects in the region.

Figure 4. Cross-sectional view of the spillway at McNary Dam showing temporary spillway weir (TSW)

(gray shaded area) design 1 (left diagram) and design 2 (right diagram). 9

Figure 5. Plan view of McNary Dam showing locations of temporary spillway weirs in 2007, 2008, and 2009 10

Figure 6. Hydrograph of mean daily project outflow (in kcfs, thousand cubic feet per second) during acoustic telemetry study dates at McNary Dam, 2006-09, and the 10-year average, 2000-09.....

Figure 7. Hydrograph of mean daily project spill (in kcfs, thousand cubic feet per second) during acoustic telemetry study dates at McNary Dam, 2006-09, and the 10-year average, 2000-09.

Figure 8. Hydrograph of mean daily water temperature (in C, degrees Celsius) of the Columbia River at McNary Dam during acoustic telemetry study dates, 2006-09, and the 10-year average, 2000-09.

Figure 9. Hydrographs showing mean discharge (in kcfs, thousand cubic feet per second) of spill bays and turbine units by treatments or conditions during spring acoustic telemetry studies at McNary Dam, 2006-09.

Figure 10. Hydrographs showing mean discharge (in kcfs, thousand cubic feet per second) of spill bays and turbine units by treatments or conditions during summer acoustic telemetry studies at McNary Dam, 2006-09. 16

Figure 11. Run timing of yearling Chinook salmon, coho salmon, juvenile steelhead, sockeye salmon, and subyearling Chinook salmon through McNary Dam for the 10-year average (black line) and 2006-09 (gray lines)... 18 


\section{Tables}

Table 1. Summary of study dates, seasonal treatment types, and seasonal mean daily project discharge for acoustic telemetry studies at McNary Dam, 2006-09.

Table 2. Mean numbers of juvenile fish passing McNary Dam between April 1 and December 1 by year and species

Table 3. Specifications of transmitters surgically implanted in juvenile salmonids, 2006-09.

Table 4. Summary statistics of fork length and weight for acoustic-tagged juvenile salmonids released in the Columbia River by release site, 2006-09

Table 5. Number of acoustic-tagged juvenile salmonids released in the Columbia River, number (and percent of those released) that passed McNary Dam, range of passage dates, and corresponding percent spill of total project discharge over dates of passage at McNary Dam, by species, 2006-09

Table 6. Percentage of fish passing McNary Dam during day and night periods in 2006 based on a one-step Markov Chain analysis.

Table 7. Percentage of fish passing McNary Dam during day and night periods in 2006 based on a two-step Markov Chain analysis.

Table 8. Percentage of fish passing McNary Dam during day and night periods in 2007 based on a one-step Markov Chain analysis.

Table 9. Percentage of fish passing McNary Dam during day and night periods in 2008 based on a one-step Markov Chain analysis.

Table 10. Percentage of fish passing McNary Dam during day and night periods in 2009 based on a one-step Markov Chain analysis.

Table 11. Percentage of fish passing McNary Dam during day and night periods in 2006 based on a one-step Markov Chain analysis.

Table 12. Percentage of fish passing McNary Dam during 2007 based on a one-step Markov Chain analysis

Table 13. Percentage of fish passing McNary Dam during day and night periods in 2008

based on a one-step Markov Chain analysis

Table 14. Percentage of fish passing McNary Dam during day and night periods in 2009 based on a one-step Markov Chain analysis

Table 15. Percentage of fish passing McNary Dam through all routes combined (TSW and standard bays)

within the spillway area by species and study year during day and night periods based on a one-step

Markov Chain analysis

Table 16. Percentage of fish passing McNary Dam during day and night periods in 2006 based on a one-step Markov Chain analysis

Table 17. Percentage of fish passing McNary Dam during day and night periods in 2007 based on a one-step Markov Chain analysis.

Table 18. Percentage of fish passing McNary Dam during day and night periods in 2008 based on a one-step Markov Chain analysis

Table 19. Percentage of fish passing McNary Dam during day and night periods in 2009 based on a one-step Markov Chain analysis

Table 20. Percentage of fish passing McNary Dam through the TSWs in the southern portion of the spillway area by species and study year during day and night periods from 2006 to 2009 based on a one-step Markov Chain analysis.....

Table 21. Percentage of fish passing McNary Dam during day period in 2006 based on a one-step Markov Chain analysis

Table 22. Percentage of fish passing McNary Dam during night period in 2006 based on a one-step Markov Chain analysis. 
Table 23. Percentage of fish passing McNary Dam during day period in 2007 based on a one-step Markov Chain analysis.

Table 24. Percentage of fish passing McNary Dam during night period in 2007 based on a

one-step Markov Chain analysis.

Table 25. Percentage of fish passing McNary Dam during day period in 2008 based on a

one-step Markov Chain analysis.

Table 26. Percentage of fish passing McNary Dam during night period in 2008 based on a

one-step Markov Chain analysis.

Table 27. Percentage of fish passing McNary Dam during day period in 2009 based on a

one-step Markov Chain analysis.

Table 28. Percentage of fish passing McNary Dam during night period in 2009 based on a

one-step Markov Chain analysis.

Table 29. Percentage of fish passing McNary Dam during day period in 2006 based on a

one-step Markov Chain analysis.

Table 30. Percentage of fish passing McNary Dam during night period in 2006 based on a

one-step Markov Chain analysis.

Table 31. Percentage of fish passing McNary Dam during day period in 2007 based on a

one-step Markov Chain analysis.

Table 32. Percentage of fish passing McNary Dam during night period in 2007 based on a

one-step Markov Chain analysis.

Table 33. Percentage of fish passing McNary Dam during day period in 2008 based on a

one-step Markov Chain analysis.

Table 34. Percentage of fish passing McNary Dam during night period in 2008 based on a

one-step Markov Chain analysis.

Table 35. Percentage of fish passing McNary Dam during day period in 2009 based on a

one-step Markov Chain analysis.

Table 36. Percentage of fish passing McNary Dam during night period in 2009 based on a

one-step Markov Chain analysis.

Table 37. Percentage of fish passing McNary Dam during day and night periods in

2006 based on a two-step Markov Chain analysis.

Table 38. Percentage of fish passing McNary Dam during day and night periods in

2007 based on a two-step Markov Chain analysis.

Table 39. Percentage of fish passing McNary Dam during day and night periods in

2008 based on a two-step Markov Chain analysis.

Table 40. Percentage of fish passing McNary Dam during day and night periods in

2009 based on a two-step Markov Chain analysis.

Table 41. Percentage of fish passing McNary Dam during day and night periods in

2006 based on a two-step Markov Chain analysis.

Table 42. Percentage of fish passing McNary Dam during day and night periods in

2007 based on a two-step Markov Chain analysis.

Table 43. Percentage of fish passing McNary Dam during day and night periods in

2008 based on a two-step Markov Chain analysis

Table 44. Percentage of fish passing McNary Dam during day and night periods in

2009 based on a two-step Markov Chain analysis.

Table 45. Percentage of fish passing McNary Dam during day and night periods in

2006 based on a two-step Markov Chain analysis.

Table 46. Percentage of fish passing McNary Dam during day and night periods in

2007 based on a two-step Markov Chain analysis 
Table 47. Percentage of fish passing McNary Dam during day and night periods in

2008 based on a two-step Markov Chain analysis.

Table 48. Percentage of fish passing McNary Dam during day and night periods in

2009 based on a two-step Markov Chain analysis.

Table 49. Simulated passage percentage of 1,000 fish at McNary Dam during day and night periods in

2006 based on a one-step Markov Chain analysis.

Table 50. Simulated passage percentage of 1,000 fish at McNary Dam during day and night periods in

2007 based on a one-step Markov Chain analysis.

Table 51. Simulated passage percentage of 1000 fish at McNary Dam during day and night periods in

2008 based on a one-step Markov Chain analysis.

Table 52. Simulated passage percentage of 1,000 fish at McNary Dam during day and night periods in

2009 based on a one-step Markov Chain analysis.

\section{Conversion Factors, Datums, Abbreviations, and Acronyms}

\section{Conversion Factors}

Inch/Pound to SI

\begin{tabular}{ccc}
\hline Multiply & By & To obtain \\
\hline & Flow rate & \\
\hline cubic foot per second $\left(\mathrm{ft}^{3} / \mathrm{s}\right)$ & 0.02832 & cubic meter per second $\left(\mathrm{m}^{3} / \mathrm{s}\right)$ \\
\hline
\end{tabular}

SI to Inch/Pound

\begin{tabular}{|c|c|c|}
\hline Multiply & By & To obtain \\
\hline \multicolumn{3}{|c|}{ Length } \\
\hline millimeter (mm) & 0.03937 & inch (in.) \\
\hline meter (m) & 3.281 & foot (ft.) \\
\hline kilometer $(\mathrm{km})$ & 0.6214 & mile (mi) \\
\hline \multicolumn{3}{|c|}{ Mass } \\
\hline $\operatorname{gram}(\mathrm{g})$ & 0.03527 & ounce, avoirdupois (oz.) \\
\hline
\end{tabular}

Temperature in degrees Celsius $\left({ }^{\circ} \mathrm{C}\right)$ may be converted to degrees Fahrenheit $\left({ }^{\circ} \mathrm{F}\right)$ as follows:

${ }^{\circ} \mathrm{F}=\left(1.8 \mathrm{x}^{\circ} \mathrm{C}\right)+32$. 


\section{Datums}

Horizontal coordinate information is referenced to the World Geodetic System of 1984 (WGS84).

Vertical coordinate information is referenced to the National Geodetic Vertical Datum of 1929 (NGVD 29).

\section{Abbreviations and Acronyms}

ATDL

ATR

CPUD

GPUD

KCFS

PIT

PUD

rkm

SI

TSW

USGS acoustic tag data loggers

acoustic tag receiver

Chelan County public utility district

Grant County public utility district

thousand cubic feet per second

passive integrated transponder

public utility district

river kilometer

modern metric system

temporary spillway weir

U.S. Geological Survey 


\title{
A Markov Chain Analysis of the Movement of Juvenile Salmonids, Including Sockeye Salmon, in the Forebay of McNary Dam, Washington and Oregon, 2006-09
}

\author{
By Noah S. Adams and Tyson W. Hatton
}

\begin{abstract}
Passage and survival data were collected at McNary Dam between 2006 and 2009. These data have provided critical information for resource managers to implement structural and operational changes designed to improve the survival of juvenile salmonids as they migrate past the dam. Much of the valuable information collected at McNary Dam was in the form of three-dimensional (hereafter referred to as 3-D) tracks of fish movements in the forebay. These data depicted the behavior of multiple species (in three dimensions) during different diel periods, spill conditions, powerhouse operations, and testing of the surface bypass structures (temporary spillway weirs; TSWs). One of the challenges in reporting 3-D results is presenting the information in a manner that allows interested parties to summarize the behavior of many fish over many different conditions across multiple years. To accomplish this, we used a Markov chain analysis to characterize fish movement patterns in the forebay of McNary Dam. The Markov chain analysis allowed us to numerically summarize the behavior of fish in the forebay.

This report is the second report published in 2012 that uses this analytical method. The first report included only fish released as part of the annual studies conducted at McNary Dam. This second report includes sockeye salmon that were released as part of studies conducted by the Chelan and Grant County Public Utility Districts at mid-Columbia River dams. The studies conducted in the midColumbia used the same transmitters as were used for McNary Dam studies, but transmitter pulse width was different between studies. Additionally, no passive integrated transponder tags were implanted in sockeye salmon. Differences in transmitter pulse width resulted in lower detection probabilities for sockeye salmon at McNary Dam. The absence of passive integrated transponder tags prevented us from determining if fish passed the powerhouse through the juvenile bypass system (JBS) or turbines. To facilitate comparison among species in this report, we combined JBS and turbine passage for yearling Chinook salmon, steelhead, and subyearling Chinook salmon even though we were able to differentiate between passage through the JBS or turbines for these three species. Information on passage proportions through the JBS and turbines can be found in the first report.

Numerically summarizing the behavior of juvenile salmonids in the forebay of McNary Dam using the Markov chain analysis allowed us to confirm what had been previously summarized using visualization software. For example, within the powerhouse region, passage proportions among the three powerhouse areas were often greater in the southern and middle areas of the powerhouse compared to the northern area of the powerhouse for yearling and subyearling Chinook salmon. The opposite generally was observed for steelhead. The results of this analysis also allowed us to confirm and quantify the extent of milling behavior that was observed for steelhead. For fish that were first detected in the powerhouse region, less than 0.10 of the steelhead, on average, passed within each of the
\end{abstract}


powerhouse areas. Instead, steelhead transitioned to adjoining areas in the spillway before passing the dam. In comparison, greater than 0.20 of the Chinook salmon passed within each of the powerhouse areas. Less milling behavior was observed for all species for fish that first approached the spillway. Compared to the powerhouse areas, a higher proportion of fish, regardless of species, passed the spillway areas and fewer transitioned to adjoining areas in the powerhouse.

In addition to quantifying what had been previously speculated about the behavior of fish in the forebay of McNary Dam, the Markov chain analysis refined our understanding of how fish behavior and passage can be influenced by changes to the operations and structure of McNary Dam. For example, the addition of TSWs to the spillway area clearly influenced the passage of fish. Previous results have been reported showing that TSWs increased passage through non-turbine routes and the fish-track videos indicated, in general, how fish behaved before passing the TSWs. However, the analysis presented in this report allowed us to better understand how fish transitioned across the face of the dam before passing the TSWs and resulted in a quantitative way to measure the effect of moving the location of the TSWs from year to year. Installation of the TSWs in bays 22 and 20 clearly increased passage proportions through the southern one-third of the spillway area for all species, most significantly for steelhead. When the TSWs were moved to bays 19 and 20 in 2008, overall passage through the southern one-third of the spillway remained higher than 2006, but decreased from what was observed in 2007. Shifting the TSWs to the north decreased the proportion of fish passing through the TSWs and increased the number of fish that transitioned to adjoining areas before passing the dam.

Perhaps the most interesting new information to come out of the two-step Markov chain analysis relates to how the performance of the TSWs was influenced by their proximity to the powerhouse. During 2007, the highest proportion of fish passing through TSW 22 was for fish that transitioned from the powerhouse area. In contrast, a relatively low proportion of fish passed through TSW 20 after coming from the powerhouse area. Instead, the proportion of fish that passed TSW 20 after coming from the northern part of the spillway was twice as high as the proportion of fish that passed through TSW 20 after coming from the powerhouse. During 2008, the TSW in bay 22 was moved to bay 19, leaving the TSW in bay 20 as the one closest to the powerhouse. As was the case when a TSW was located in bay 22 , the proportion of fish passing through TSW 20 after coming from the powerhouse was higher than the proportion of fish passing TSW 20 after coming from the northern part of the spillway. Passage proportions for fish passing through TSW 19, the farthest north of the two TSWs during 2008, was higher for fish that came from the northern part of the spillway compared to the proportion of fish that passed through TSW 19 after coming from the powerhouse.

The Markov chain analysis provided a mathematical way to characterize fish behavior in the forebay of McNary Dam and helped refine our understanding of how fish movements were influenced by operational and structural changes at the dam. The numerical information used to quantify the behavior of fish also can be used to construct simulations to examine how proposed fish passage structures might influence passage of juvenile salmonids. To demonstrate this, we used the results of the Markov chain analysis to examine how a virtual fish collector located in the center of the powerhouse might influence passage of juvenile salmonids at McNary Dam. 


\section{Introduction}

As juvenile salmon (Oncorhynchus spp.) and steelhead (O. mykiss) migrate from their natal streams to the ocean, they are subject to both natural and human-caused mortality. Avian and piscivorous predators contribute to natural mortality, but hydroelectric projects on the Snake and Columbia Rivers also are sources of mortality for migrating juvenile fish. Studies conducted at McNary Dam between 2002 and 2005 provided baseline passage and survival information under typical dam operations (Axel and others, 2004a, 2004b; Perry and others, 2006, 2007a). These studies found that non-turbine passage routes, such as the spillway and juvenile bypass system, provided higher survival compared to the turbines. Additional studies at Lower Granite Dam showed that surface passage structures appear to be a safe alternative to passage through the turbines (Plumb and others, 2004; Beeman and others, 2007; Perry and others, 2007b; Puls and others, 2008). As a result of these studies, surface bypass structures (temporary spillway weirs; TSW) were installed at McNary Dam and performance tests were conducted in 2007, 2008, and 2009.

The 8 years of study at McNary Dam (2002-09) provided information that aided in developing management strategies designed to maximize passage and survival of juvenile salmonids passing the dam while meeting regional hydroelectric power generation needs. The research from the annual studies conducted at McNary Dam between 2006 and 2009 have been synthesized and presented in a single report (Adams and Evans, 2011). Summarizing the annual information in a single document is expected to provide a useful reference for managers during the development of long-term management strategies for McNary Dam.

Although these annual studies provided valuable information, important questions remain unanswered. Managers are often interested in understanding how rates of survival and passage vary with environmental conditions, such as total river discharge or distribution of discharge across possible passage routes. Understanding how survival or passage varies in response to dam operations requires data for a wide range of conditions. Studies conducted in a single year only consider a narrow range of environmental conditions, due to natural year-to-year variation in the environment. Multiyear analyses are better suited to developing quantitative relationships than are single-year analyses, because operational and environmental variation typically will be higher over a period of 5-10 years than within any given year. Furthermore, multiyear analyses benefit from the large sample sizes over multiple years, which can reduce statistical uncertainty and help to identify relations that might otherwise be statistically undetectable. We analyzed 6 years (2004-09) of passage and survival data collected at McNary Dam to determine how dam operations and environmental conditions affect passage and survival of juvenile salmonids. The results of that analysis are presented in a separate report (Adams and others, 2011).

Much of what was learned from the information collected at McNary Dam was acquired from analyses of three-dimensional (hereafter referred to as 3-D) tracks of fish movements in the forebay. These tracks depicted the movement behavior of multiple species (in three dimensions) during different diel periods, spill conditions, powerhouse operations, and test configurations of the TSWs. One of the challenges in reporting 3-D results is presenting the information in a manner that allows interested parties to summarize the behavior of many fish over many different conditions across multiple years. 
To help facilitate this, the U.S. Geological Survey (USGS) worked with a software development company (Myriax Software Pty Ltd., Hobart, Tasmania, Australia) in 2010 to produce a software interface (Eonfusion ${ }^{\mathrm{TM}}$ ) to allow users to query the data, summarize it across multiple species and conditions, and visualize the fish movement tracks in a 3-D format. The USGS continued to refine the software interface in 2011. Although the initial software provides an excellent way to summarize and visualize 3-D data, it is still a relatively complex task and needs to be simplified so interested parties are more likely to take advantage of this powerful tool.

Even with the refinement of the software interface, it will only summarize, not analyze, the 3-D movement information. For example, the software interface will allow the user to visually examine all of the fish movement tracks for all fish that approached the spillway during the night, but does not have the capacity to numerically analyze the data. The software lacks the ability to quantify the inherently qualitative nature of the fish movement tracks. This was the main objective of the study and to accomplish this we used a Markov chain analysis to numerically characterize fish movement patterns in the forebay of McNary Dam (Steel and others, 2001; Johnson and others, 2004).

\section{Markov Chain Methods}

A Markov chain is a stochastic process that specifies the probability of transitioning (moving) from one state to another. States, in this case, were four discrete areas across the face of the dam, which consisted of three-dimensional volumes of water bounded by the water surface and the river bottom, and extended from the face of the dam upstream $60 \mathrm{~m}$ (fig. 1). Within each state, fish can either pass the dam or swim to an adjoining state (fig. 2). A fish is said to have been absorbed within the state if they pass the dam, and the term "transition" is used to describe movement from one state to another. The transition history of individual fish movements between states is used to construct a transition matrix, and includes all fish movement information within $60 \mathrm{~m}$ of the upstream face of McNary Dam. Because fish swam back and forth upstream of the dam, individual fish were counted multiple times within each state. For instance, a single fish may have entered and exited the same state multiple times before it was absorbed in any particular state. As a result, it was possible to have, for example, 100 transitions from state $\mathrm{Y}$ to state $\mathrm{Z}$ that were based on the movements of 10 individual fish that traveled from state $\mathrm{Y}$ to state $\mathrm{Z}$ on 10 separate occasions. Equally plausible is that 100 individual fish each moved only once between state $\mathrm{Y}$ and $\mathrm{Z}$. The transition matrix was then used to calculate the probability of fish movement from one state to the next for all four states upstream of McNary Dam.

The probability of moving from one state to another is assumed to be independent of the state the fish was in previously. Therefore, transitioning out of state $\mathrm{Y}$ is not dependent on the state the fish was in previously. This is the primary assumption of a one-step Markov chain analysis. To investigate how fish movement from one state depended on the state the fish was in previously, we also constructed a two-step analysis. The two-step analysis examined the movement of fish in state $\mathrm{Y}$ as a function of which state they were in previously. For example, if states $\mathrm{X}, \mathrm{Y}$, and $\mathrm{Z}$ represented adjoining states located across the upstream face of the dam, we examined the movements of fish out of state $Y$ that had moved into $\mathrm{Y}$ from $\mathrm{X}$, as well as the movements of fish out of state $\mathrm{Y}$ that had moved into $\mathrm{Y}$ from state $Z$. Both the one-step and two-step analyses allowed us to investigate and quantify the movement behavior of fish upstream of McNary Dam. 


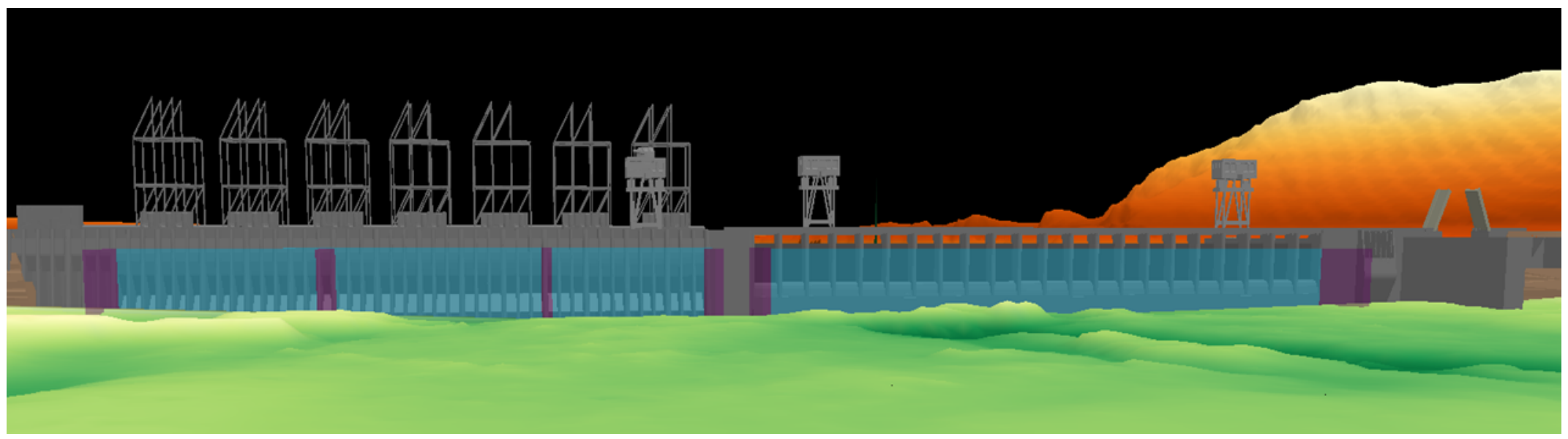

Figure 1. Graphical representation of the upstream face of McNary Dam showing the powerhouse (left) and spillway (right). The vertical purple lines indicate how the area upstream (within $60 \mathrm{~m}$ ) of the dam was partitioned into four areas for the Markov chain analysis.

\section{Powerhouse Turbine Units (Area)}

$1-5 \quad 6-10 \quad 11-14$

(PH\#1) $\quad(\mathrm{PH} 2) \quad(\mathrm{PH})$

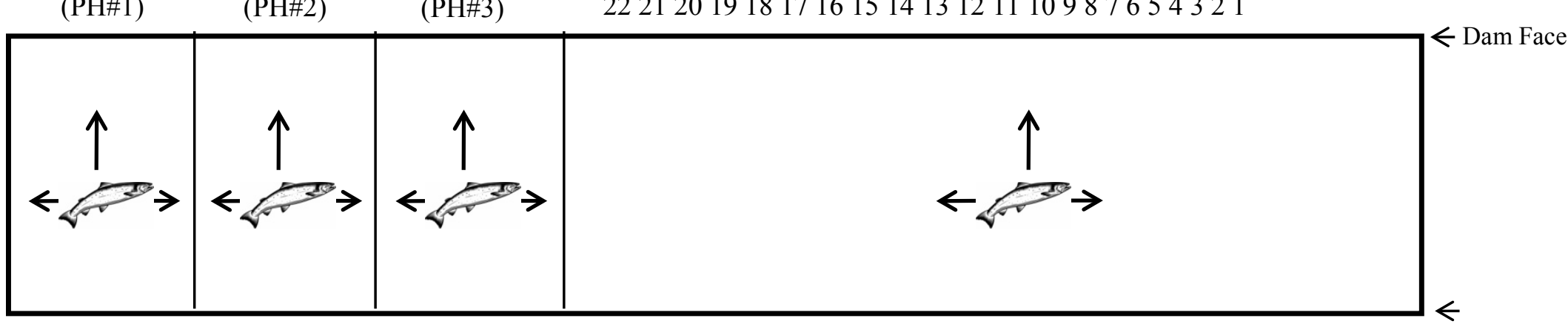

Figure 2. Diagram showing a top view of the three powerhouse areas (PH\#1, PH\#2, PH\#3) and the spillway area upstream of McNary Dam used in the Markov chain analysis. Within each area, the one-step analysis examined the probability of fish passing the dam or transitioning to an adjoining area. The two-step analysis examined the probability of a fish passing the dam or transitioning to an adjoining area as a function of the area it was in previously.

\section{Spillway Bay Numbers}

22212019181716151413121110987654321 


\section{Evaluation of a Virtual Fish Collector}

The Markov chain analysis provided a mathematical way to characterize fish behavior in the forebay of McNary Dam and helped refine our understanding of how fish movements were influenced by operational and structural changes at the dam. The numerical information used to quantify the behavior of fish also can be used to construct simulations to examine how proposed fish passage structures might influence passage of juvenile salmonids. To demonstrate this, we used the results of the Markov chain analysis to examine how a virtual fish collector (VFC) in the center of the powerhouse might influence passage of juvenile salmonids at McNary Dam. For this simulation, the VFC was located in the powerhouse \#2 (PH\#2) area of the powerhouse (fig. 2). The effect of the VFC on passage proportions was evaluated using the 2006 data (a year when no TSWs were installed at McNary Dam) as well as the data from 2007, 2008, and 2009 (years when TSWs were tested at various locations in the spillway). It is important to note that the simulation cannot be used to design the actual structure of a VFC. The VFC was a dimensionless structure and therefore did not have a unique structure or defined number of openings, nor were the openings restricted to any particular shape (for example, wide and shallow or narrow and deep). The simulation is based on the anticipated efficiency of the VFC, not how the VFC looks, and we chose to use efficiencies of 30 and 50 percent in the simulation. To provide a reference to gauge the relative effect of a VFC on fish passage at McNary Dam, we also simulated a VFC that was 0 percent efficient at passing fish. Additionally, we chose to only include yearling and subyearling Chinook salmon in the simulation. Steelhead were not included because it has been previously demonstrated at many locations in the Columbia River Basin that steelhead pass through surface bypass structures at relatively high proportions compared to the other two species. Relatively high numbers of steelhead passed the TSWs in the spillway of McNary Dam in 2007, 2008, and 2009. With the majority of the steelhead passing the TSWs, few would remain to simulate the influence of a VFC in the powerhouse.

To simulate the effect of a VFC on passage proportions, we assumed that a fish had a 30 or 50 percent chance of entering the VFC if it traveled into the PH\#2 area. Passage proportions were reduced through the other passage routes (PH\#1, $\mathrm{PH} 3$, and spillway) by 30 or 50 percent for fish that traveled through the $\mathrm{PH} \# 2$ area. The passage proportions remained unaltered for fish that did not travel through the PH\#2 area. This is important to remember because, for example, if no fish entered the PH\#2 area, the passage proportions remained unchanged through the other passage routes even if we assumed the VFC was 100 percent efficient. The fact that the VFC affected only fish that traveled into the PH\#2 area could have resulted in fewer than 30 or 50 percent of the total fish in the simulation passing through the VFC.

\section{Environmental and Biological Setting}

\section{Project Description}

McNary Dam is the fourth dam upstream of the mouth of the Columbia River, located 470 river kilometers (rkm) upstream of the Pacific Ocean and $52 \mathrm{rkm}$ downstream of the confluence of the Columbia and Snake Rivers. The reservoir formed by McNary Dam (Lake Wallula) extends $98 \mathrm{rkm}$ upstream to the Hanford Reach on the Columbia River, and impounds 16 rkm of the Snake River upstream to Ice Harbor Dam. The river downstream of McNary Dam (Lake Umatilla) is impounded by John Day Dam located 123 rkm downstream of McNary Dam. The study area encompassed $482 \mathrm{~km}$, extending from the tailrace of Wells Dam (rkm 830), the upper most release point for tagged fish, to our most downstream detection array located at John Day Dam (rkm 348) (fig. 3). 
McNary Dam is oriented perpendicular to the river channel with a navigation lock, spillway, powerhouse, and earthen dam. The spillway is $399 \mathrm{~m}$ long with 22 vertical lift-type spill gates that regulate discharge through the dam. The spillway discharges water at the ogee crest approximately $14 \mathrm{~m}$ below the water surface. The powerhouse at McNary Dam is $433 \mathrm{~m}$ long with 14 turbine units. Each turbine unit has a generating capacity of 70 megawatts and a hydraulic capacity of $16.6 \mathrm{kcfs}$ (thousand cubic feet per second, or $\left.\left[1,000 \mathrm{ft}^{3} / \mathrm{s}\right]\right)$. The turbine intakes are about $19 \mathrm{~m}$ deep, and are divided into three smaller, fully isolated slots. Each slot has a vertical barrier screen, trash rack (designed to prevent large debris from entering the turbines), and an extended-length submersible barrier screen that guides downstream migrating fish away from the turbine intakes and into the fish collection channel (orifice gallery). The guided fish are then routed through a series of pipes and channels to the juvenile fish bypass facility and held in concrete raceways where they await downstream transportation by barge or truck, or are routed back into the river to continue their migration. No study fish with passive integrated transponder (PIT) tags were barged during the four study years.

Two TSW designs were tested during 2007, 2008, and 2009 (fig. 4). Different locations were tested for TSW design 1 during the study years to determine if TSW location affected fish passage or survival. TSW design 1 was installed in spill bay 22 during 2007, spill bay 19 during 2008, spill bay 4 during spring 2009, and spill bay 19 during summer 2009 (fig. 5). TSW design 2 was installed in spill bay 20 during all three study years. Each TSW was comprised of a weir crest, set atop the spill leaf gate within the spill bay. The weir crest extended from the top of the ogee crest to about $2.4 \mathrm{~m}$ below the surface, thereby causing water to spill from the surface of the forebay rather than from $14 \mathrm{~m}$ below the surface like conventional spill bays. Discharge over the TSWs was a function of forebay elevation, and because TSW design 1 was about $0.2 \mathrm{~m}$ deeper than TSW design 2 , discharge through TSW design 1 was, on average, slightly greater (about $600 \mathrm{ft}^{3} / \mathrm{s}$ ) than discharge through TSW design 2 . The difference in the elevation of the TSWs was the result of structural differences (fig. 4) to test the efficacy of varying entrance conditions for passing juvenile salmonids.

\section{River Conditions}

Mean daily discharge at McNary Dam throughout the season was variable, depending on year (fig. 6). The 10-year average (2000-09) discharge in mid-April was about $210 \mathrm{kcfs}$, increasing to more than $250 \mathrm{kcfs}$ by late May, decreasing through June and July, and ending at less than $150 \mathrm{kcfs}$ by August. Our study years followed a similar trend but were more pronounced, depending on the year. Of the years 2000-09, the median daily project outflow for the spring study dates of 2006, 2009, and 2008 ranked as the highest 3 years with 2007 ranking fifth of the 10 years. During the summer study dates, 2008 and 2006 were ranked second and third highest and 2007 and 2009 ranked fifth and sixth for median daily project outflow.

Mean daily spill at McNary Dam from 2000 to 2009 followed a similar trend to mean daily discharge (fig. 7). Mean daily spill in mid-April, at the start of the season, averaged $80 \mathrm{kcfs}$ and peaked in late May or early June at $125 \mathrm{kcfs}$ for the 10-year average. In 2008, the average daily maximum spill was $250 \mathrm{kcfs}$. Daily spill typically was lowest in July, near the end of the study period, at an average of 50 kcfs.

Water temperature steadily increased during the study period, rising from $9^{\circ} \mathrm{C}$ in April to a peak of about $21^{\circ} \mathrm{C}$ in late July or early August (fig. 8). Water temperatures were slightly lower $\left(1-2^{\circ} \mathrm{C}\right)$ in 2008 than in the other three study years. 


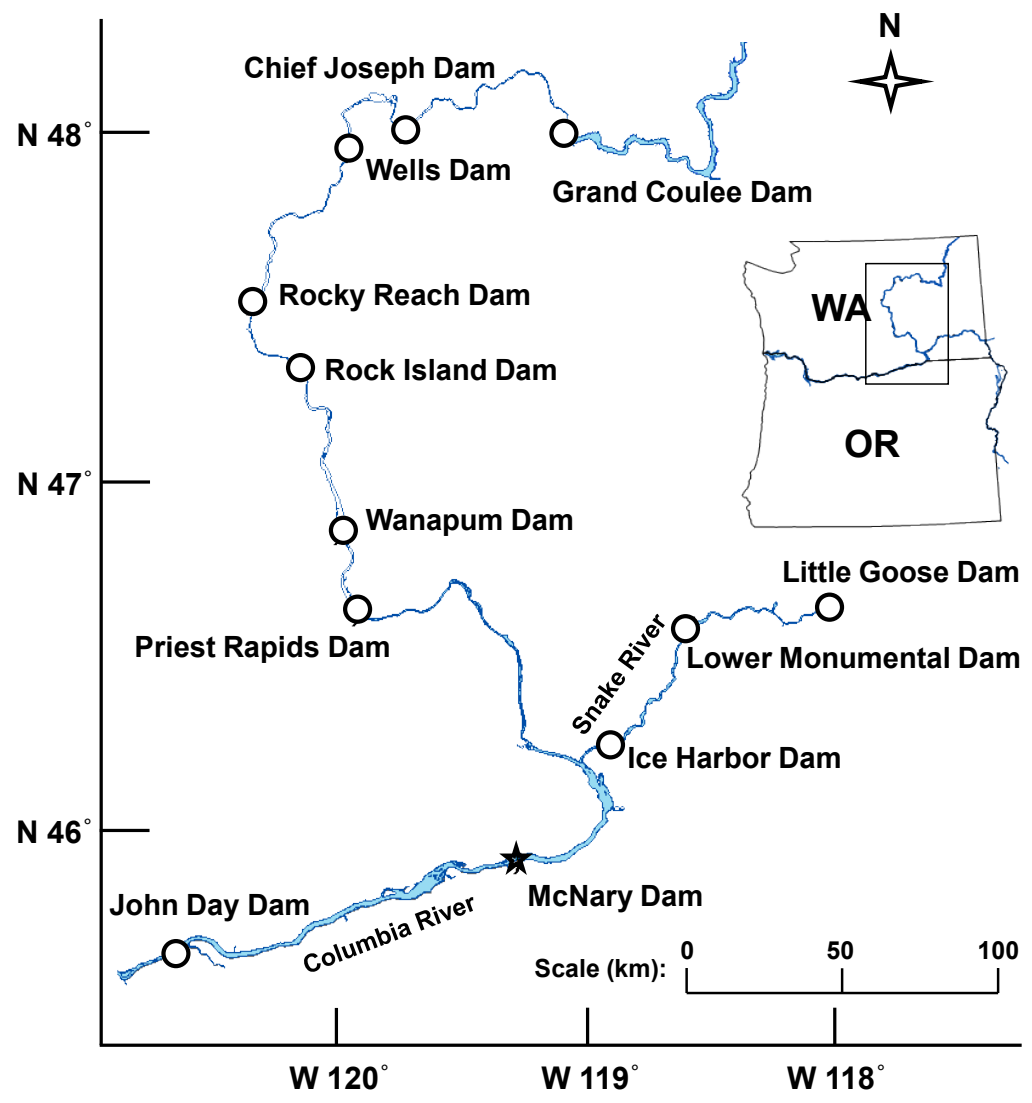

Figure 3. Map showing Columbia and Snake Rivers and the location of McNary Dam relative to other major hydroelectric projects in the region. 

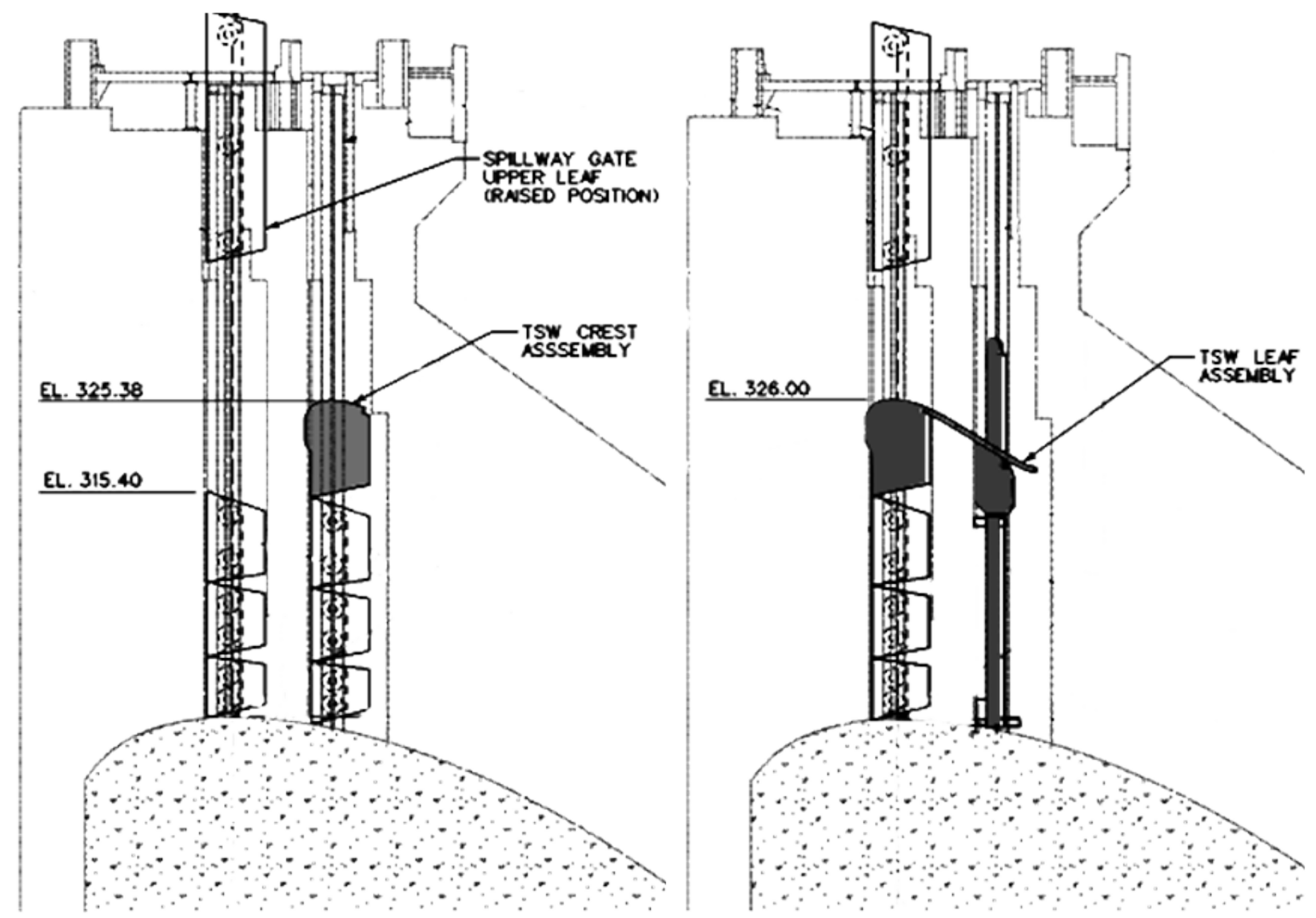

Figure 4. Cross-sectional view of the spillway at McNary Dam showing temporary spillway weir (TSW) (gray shaded area) design 1 (left diagram) and design 2 (right diagram). Water spilled over the TSW crest from the forebay (left side of page) to the tailrace (right side of page). 
TSW Design 1

TSW Design 2
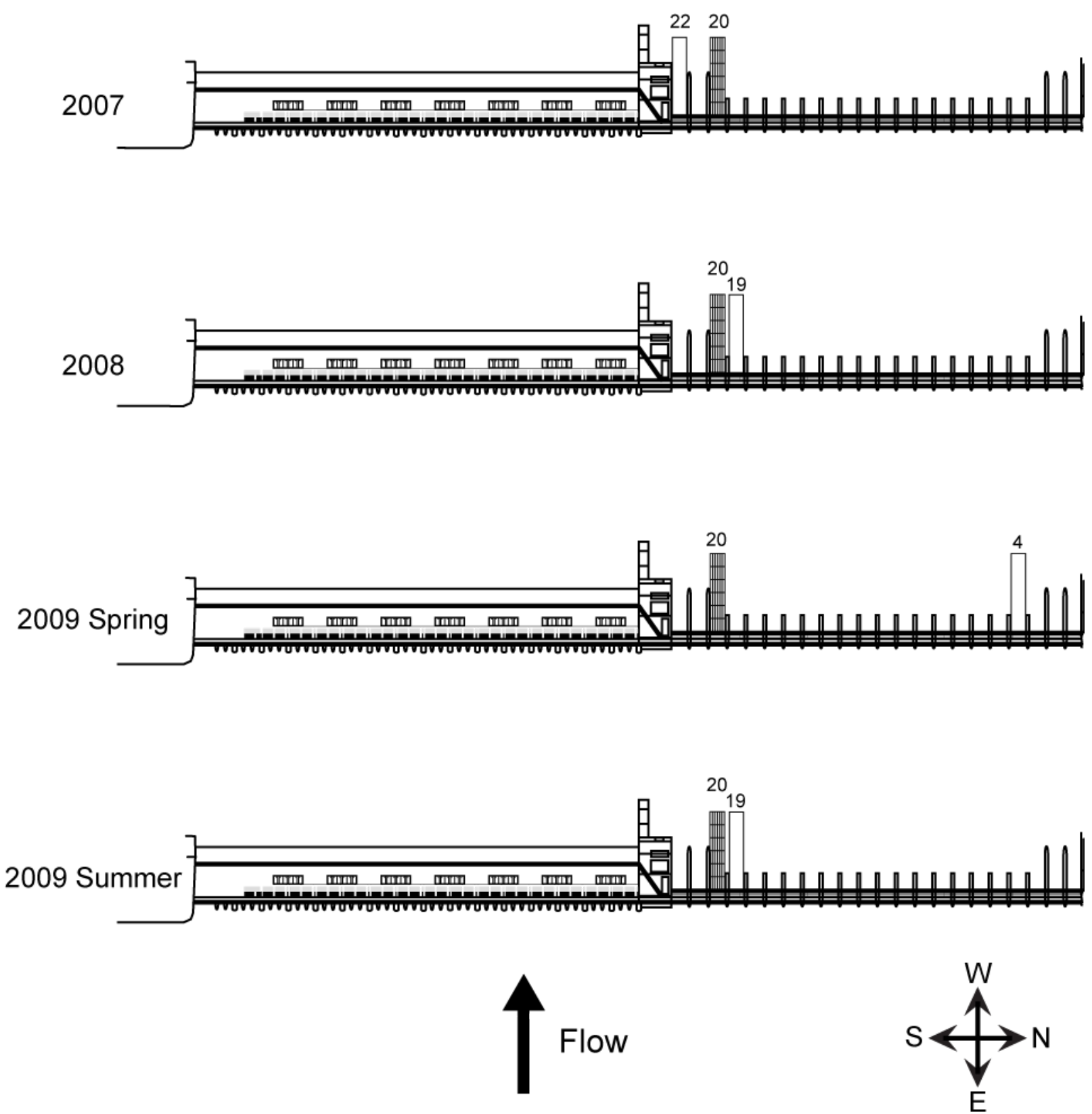

Figure 5. Plan view of McNary Dam showing locations of temporary spillway weirs (TSWs) in 2007, 2008, and 2009. Numbers above the TSW icon indicate spill bay number. There were no TSWs in 2006. 


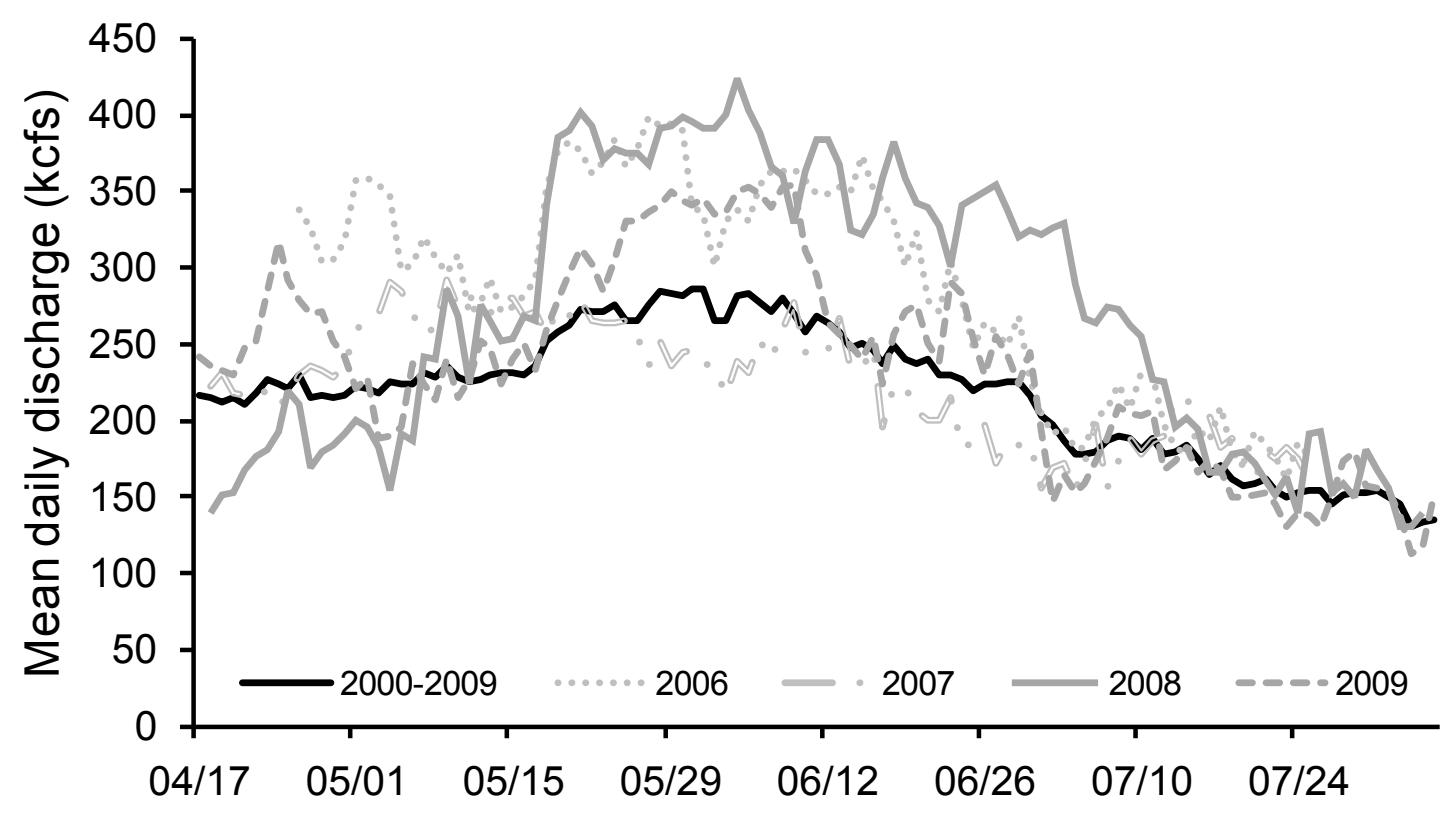

Figure 6. Hydrograph of mean daily project outflow (in kcfs, thousand cubic feet per second) during acoustic telemetry study dates at McNary Dam, 2006-09, and the 10-year average, 2000-09. Data obtained from Columbia River DART website: http://www.cbr.washington.edu/dart/river.html. 


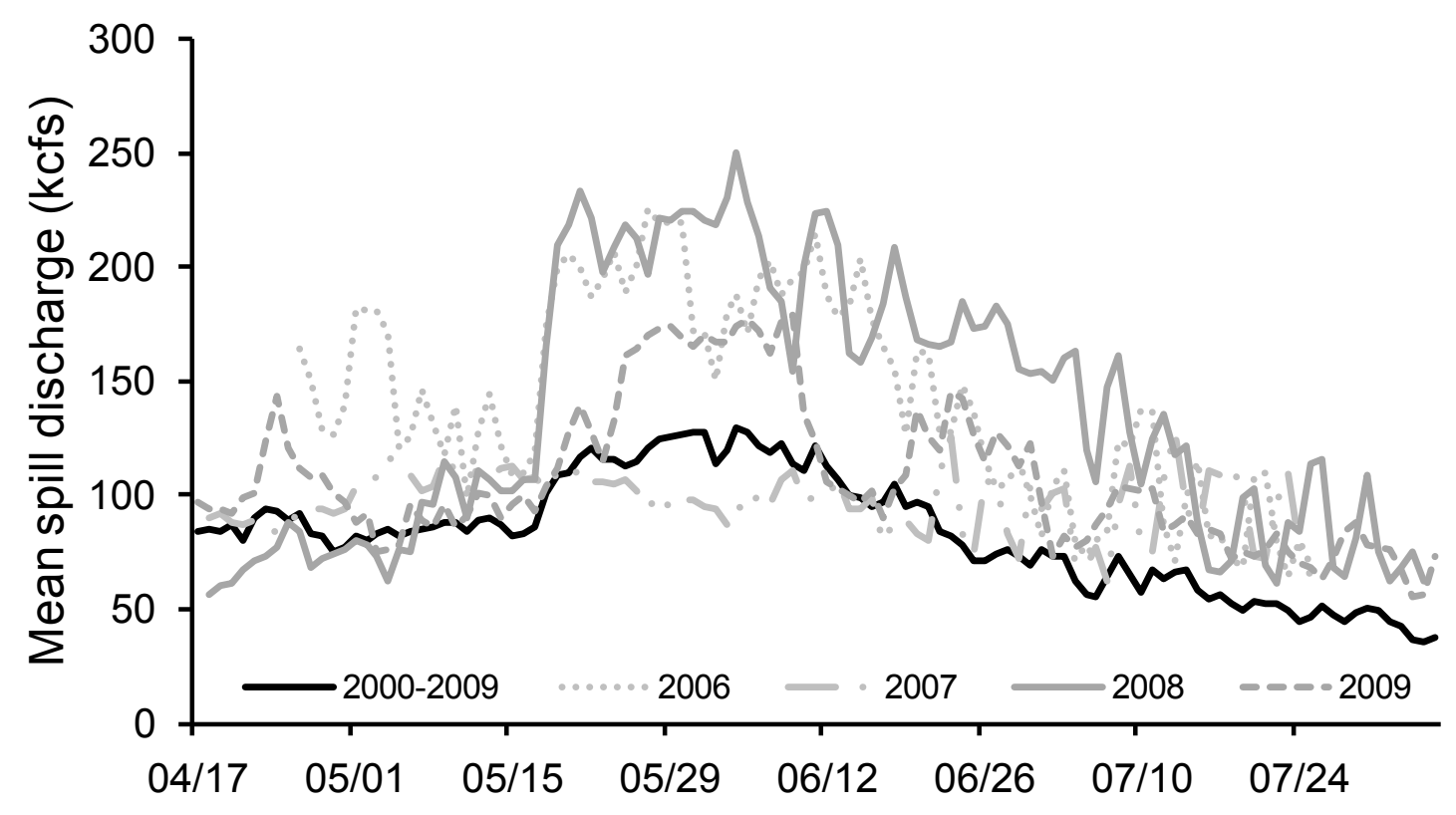

Figure 7. Hydrograph of mean daily project spill (in kcfs, thousand cubic feet per second) during acoustic telemetry study dates at McNary Dam, 2006-09, and the 10-year average, 2000-09. Data obtained from Columbia River

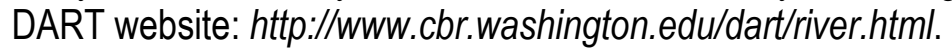

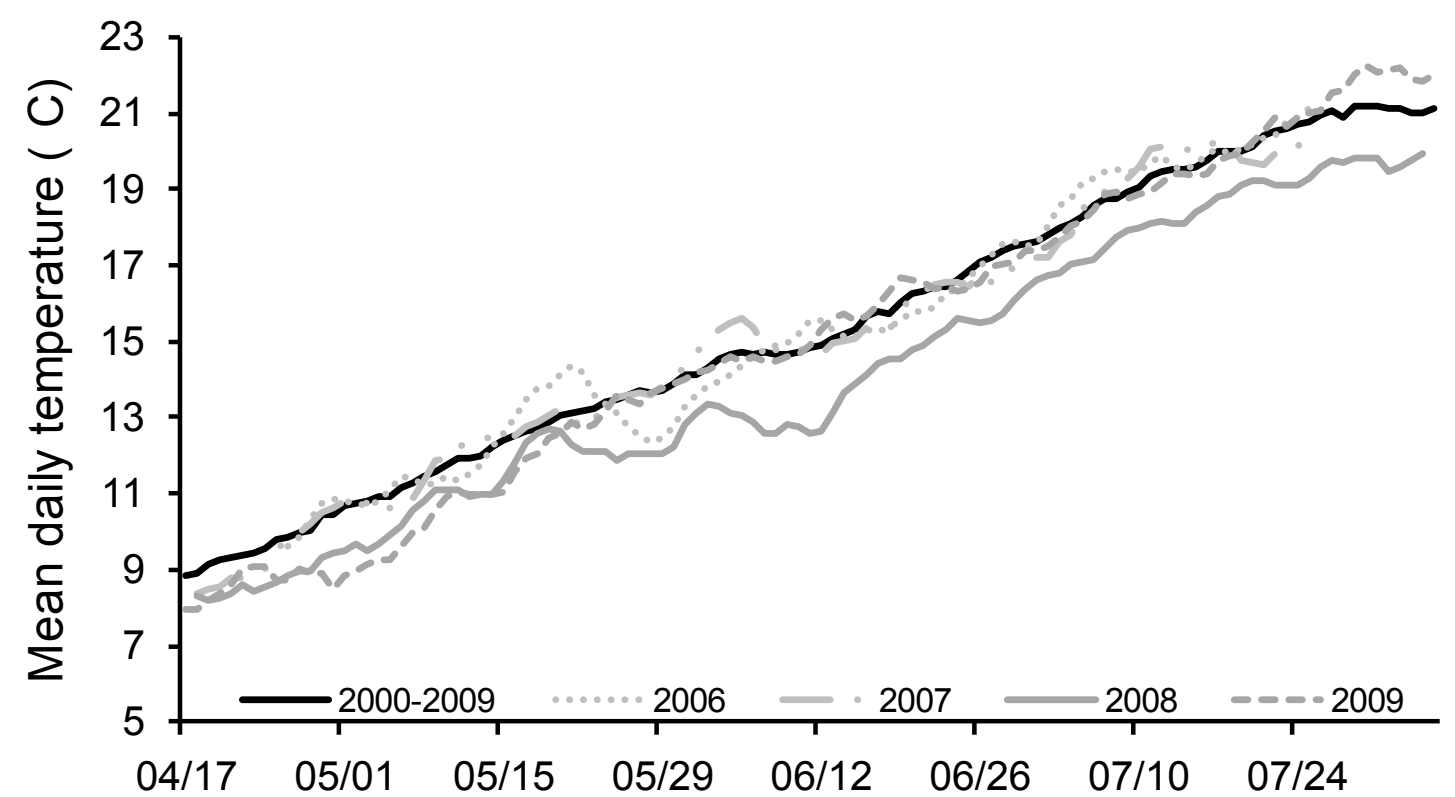

Figure 8. Hydrograph of mean daily water temperature (in C, degrees Celsius) of the Columbia River at McNary Dam during acoustic telemetry study dates, 2006-09, and the 10-year average, 2000-09. Data obtained from Columbia River DART website: $h$ ttp://www.cbr.washington.edu/dart/river.html. 


\section{Project Operations and Study Treatments}

Several treatments and operation schemes were implemented at McNary Dam between 2006 and 2009 (table 1; figs. 9 and 10). Two treatments (Fish Passage Plan and 2006 Test Spill) were conducted during spring 2006. The Fish Passage Plan treatment consisted of high discharge at the northern end of the spillway. Conversely, the 2006 Test Spill pattern consisted of high discharge at the southern end of the spillway. During spring 2007, the two treatments were a modification of the 2006 Test Spill (hereafter called Modified 2006 Test Spill) and a 2007 Test Spill pattern. Investigations into dam operations based on this schedule, however, revealed few differences between the spill treatments. Differences in spill bay- and turbine-specific discharge primarily were associated with spill bays 15, 16, and 17 (fig. 9). No treatments were planned in spring 2008 or 2009; however, we characterized two treatments in 2008. During the first one-half of the spring season (April 18-May 17), discharge through the spillway was 40 percent, hereafter called Early Season. During the second one-half of the season (May 17-June 9), spillway discharge was 50-60 percent, hereafter called Late Season. We were unable to characterize any spill patterns in 2009.

Only two planned treatment types occurred during the summer seasons between 2006 and 2009 (fig. 10). For the 2006 and 2007 treatments, two dam operations were evaluated: 24-hour (h) spill at 40 percent of total river discharge and 24-h spill at 60 percent of total river discharge. Sixty percent spill and 40 percent spill also were planned and implemented in 2008 in randomized 4-day (d) blocks; however, the treatments began after July 3. Prior to July 3, high dissolved gas levels and involuntary spill prevented operation at the treatment level. The period of time before July 3 is hereafter called Early Season, which consisted of approximately 50 percent spill of total project discharge. No treatments were planned or characterized in summer 2009. For both spring and summer, diel periods were assigned as day (0600-1759 hours) and night (1800-0559 hours). 
Table 1. Summary of study dates, seasonal treatment types, and seasonal mean daily project discharge for acoustic telemetry studies at McNary Dam, 2006-09.

[Discharge is measured in thousand cubic feet per second. \%, percent; NA, not applicable]

\begin{tabular}{|c|c|c|c|c|}
\hline & 2006 & 2007 & 2008 & 2009 \\
\hline Spring study dates & Apr 26-June 07 & Apr 18-June 06 & Apr 18-June 09 & Apr 17-June 10 \\
\hline \multirow[t]{2}{*}{ Spring Treatments $^{1}$} & Fish Passage Plan & Modified 2006 test spill & Early season (40\% spill) & NA \\
\hline & 2006 test spill & 2007 test spill & Late season $(50-60 \%$ spill $)$ & NA \\
\hline TSW Design 1 location & NA & Spill bay 22 & Spill bay 19 & Spill bay 4 \\
\hline TSW Design 2 location & NA & Spill bay 20 & Spill bay 20 & Spill bay 20 \\
\hline \multirow{2}{*}{ Summer Treatments $^{1}$} & $40 \%$ spill & $40 \%$ spill & $60 \%$ spill & NA \\
\hline & NA & NA & $40 \%$ spill & NA \\
\hline Mean project discharge & 219.2 & 184.0 & 241.0 & 184.9 \\
\hline TSW Design 1 location & NA & Spill bay 22 & Spill bay 19 & Spill bay $19^{2}$ \\
\hline TSW Design 2 location & NA & Spill bay 20 & Spill bay 20 & Spill bay 20 \\
\hline
\end{tabular}

${ }^{1}$ Treatments represent proposed spill patterns or percentage of total project discharge. Although 2008 had no proposed treatments, treatments were characterized based on distinct flow patterns. 2009 had no proposed treatments and none were characterized.

${ }^{2}$ TSW Design 1 was moved to spill bay 19 for the 2009 summer study, but passage could only be calculated for spill bays 16-19 as a group. 


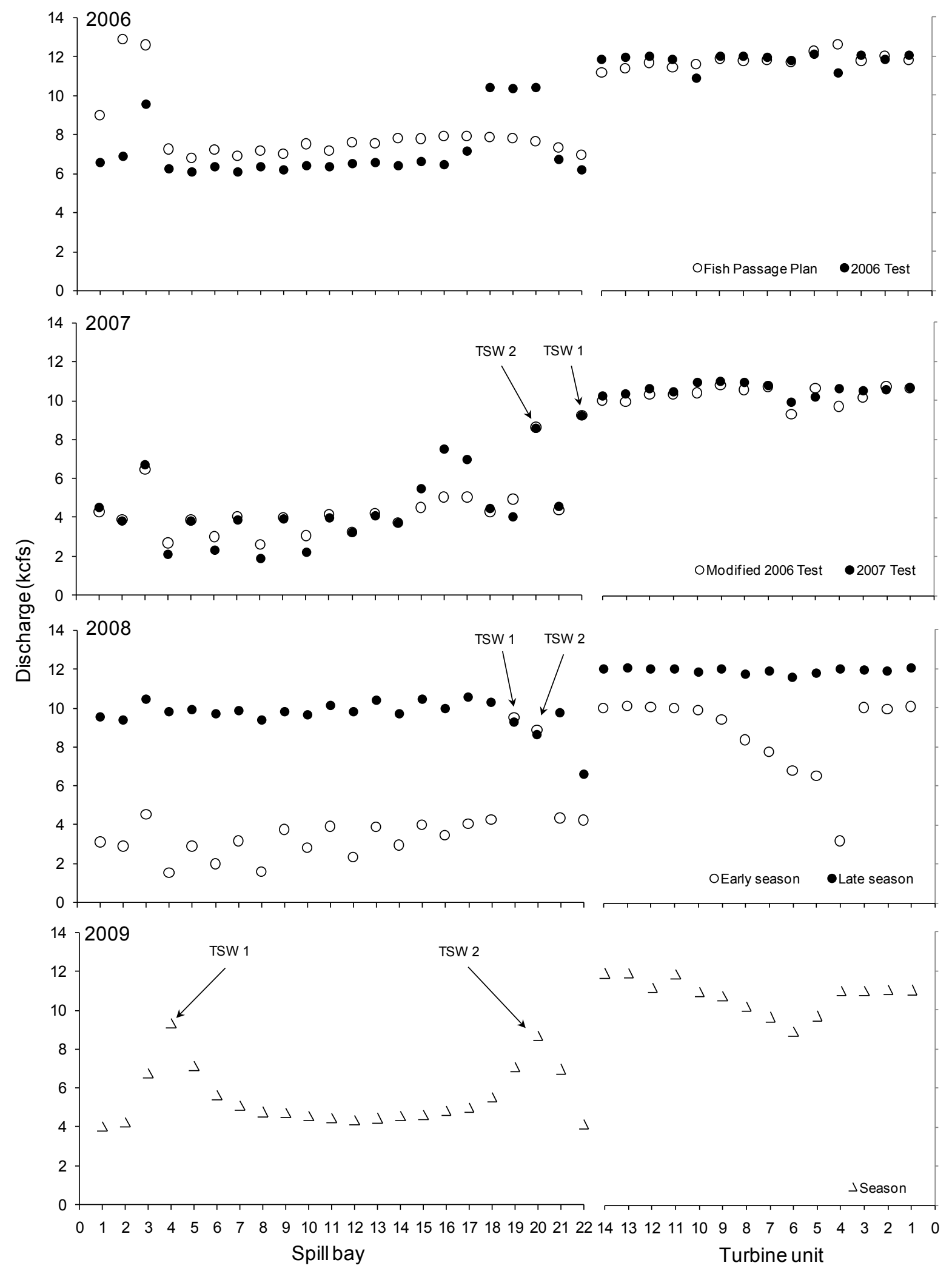

Figure 9. Hydrographs showing mean discharge (in kcfs, thousand cubic feet per second) of spill bays and turbine units by treatments or conditions during spring acoustic telemetry studies at McNary Dam, 2006-09. 


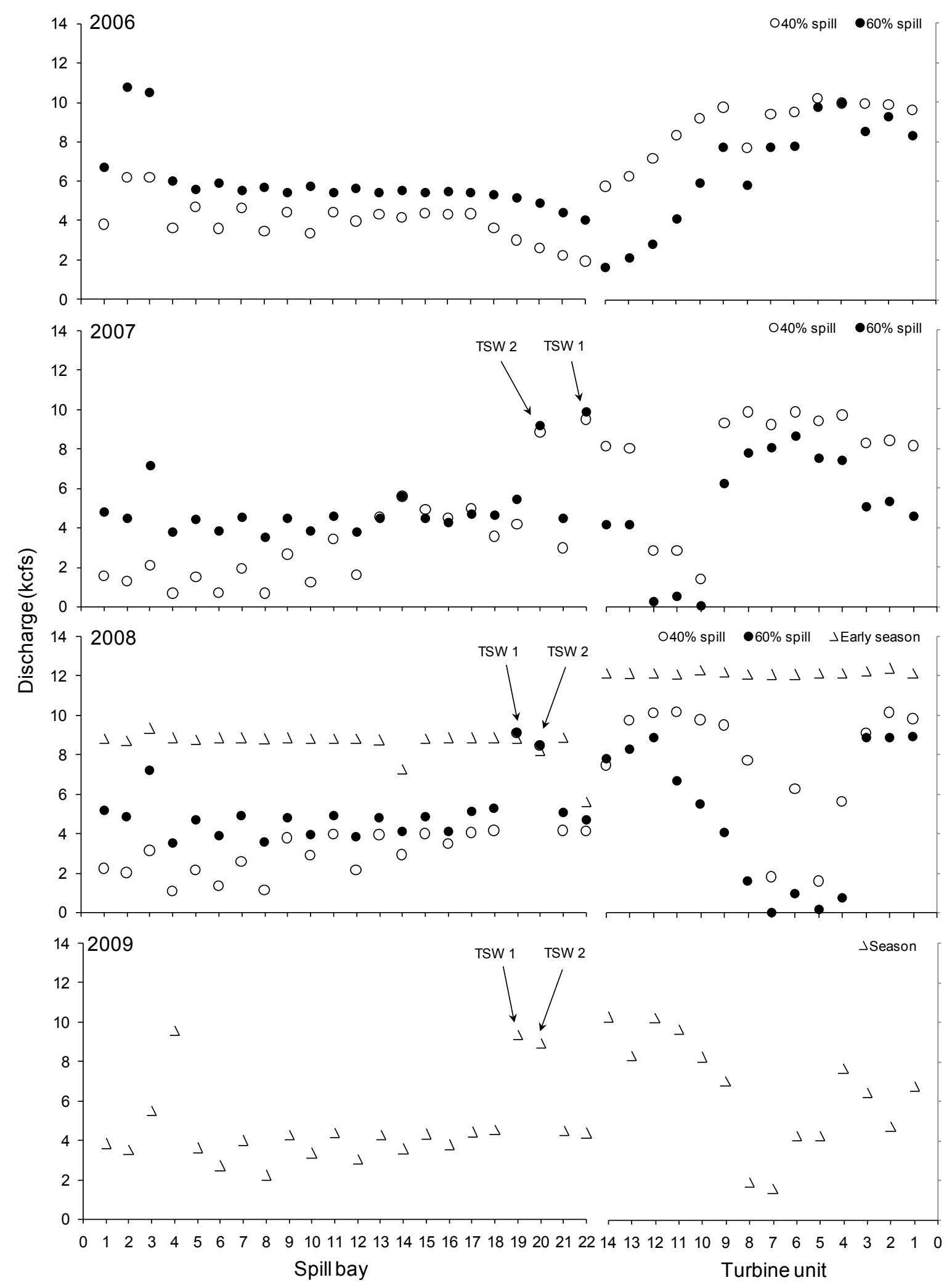

Figure 10. Hydrographs showing mean discharge (in kcfs, thousand cubic feet per second) of spill bays and turbine units by treatments or conditions during summer acoustic telemetry studies at McNary Dam, 2006-09. 


\section{Species Composition and Run Timing}

Run timing from 2006 to 2009 at McNary Dam varied by species and year, and generally followed the 10-year average in pattern but not in scale. During the spring, juvenile yearling Chinook salmon (Oncorhynchus tshawytscha), coho salmon (O. kisutch), sockeye salmon (O. nerka), and steelhead (O. mykiss) made up the majority of the fish run, but yearling Chinook salmon and juvenile steelhead were the most prevalent (fig. 11). Subyearling Chinook salmon made up the greatest proportion of the fish run during the summer study periods as well as over the entire 4-year study period (0.566; table 2). On a yearly basis, the number of sockeye and subyearling Chinook salmon passing McNary Dam was greatest in 2007, the number of yearling Chinook salmon and juvenile steelhead passing McNary Dam was greatest in 2009, and the largest number of coho salmon passed McNary Dam in 2008. Most fish runs that passed McNary Dam in the spring from 2006 to 2009 had higher daily counts than the 10-year average. Only the subyearling Chinook salmon run in 2006-09 matched the 10year average daily frequency, but the peak of the run during 2006-09 peaked several weeks later than the 10-year average.

Table 2. Mean numbers of juvenile fish passing McNary Dam between April 1 and December 1 by year and species.

[Proportion is the total number of each species divided by all fish passing McNary Dam. Data obtained from the Fish Passage Center (http://www.fpc.org)]

\begin{tabular}{lrrrrrc}
\hline \multicolumn{1}{c}{ Species } & \multicolumn{1}{c}{$\mathbf{2 0 0 6}$} & \multicolumn{1}{c}{$\mathbf{2 0 0 7}$} & \multicolumn{1}{c}{$\mathbf{2 0 0 8}$} & $\mathbf{2 0 0 9}$ & \multicolumn{1}{c}{ Total } & Proportion \\
\hline Yearling Chinook salmon & $1,559,649$ & $2,223,432$ & $1,299,990$ & $2,249,069$ & $7,332,140$ & 0.280 \\
Coho & 102,125 & 99,101 & 168,497 & 127,002 & 496,725 & 0.019 \\
Sockeye & 496,470 & 512,994 & 221,747 & 190,747 & $1,421,958$ & 0.054 \\
Steelhead & 442,984 & 376,449 & 506,527 & 803,445 & $2,129,405$ & 0.081 \\
Subyearling Chinook salmon & $4,064,681$ & $4,721,057$ & $2,408,207$ & $3,652,430$ & $14,846,375$ & 0.566 \\
Total & $6,665,909$ & $7,933,033$ & $4,604,968$ & $7,022,693$ & $26,226,603$ & \\
\hline
\end{tabular}



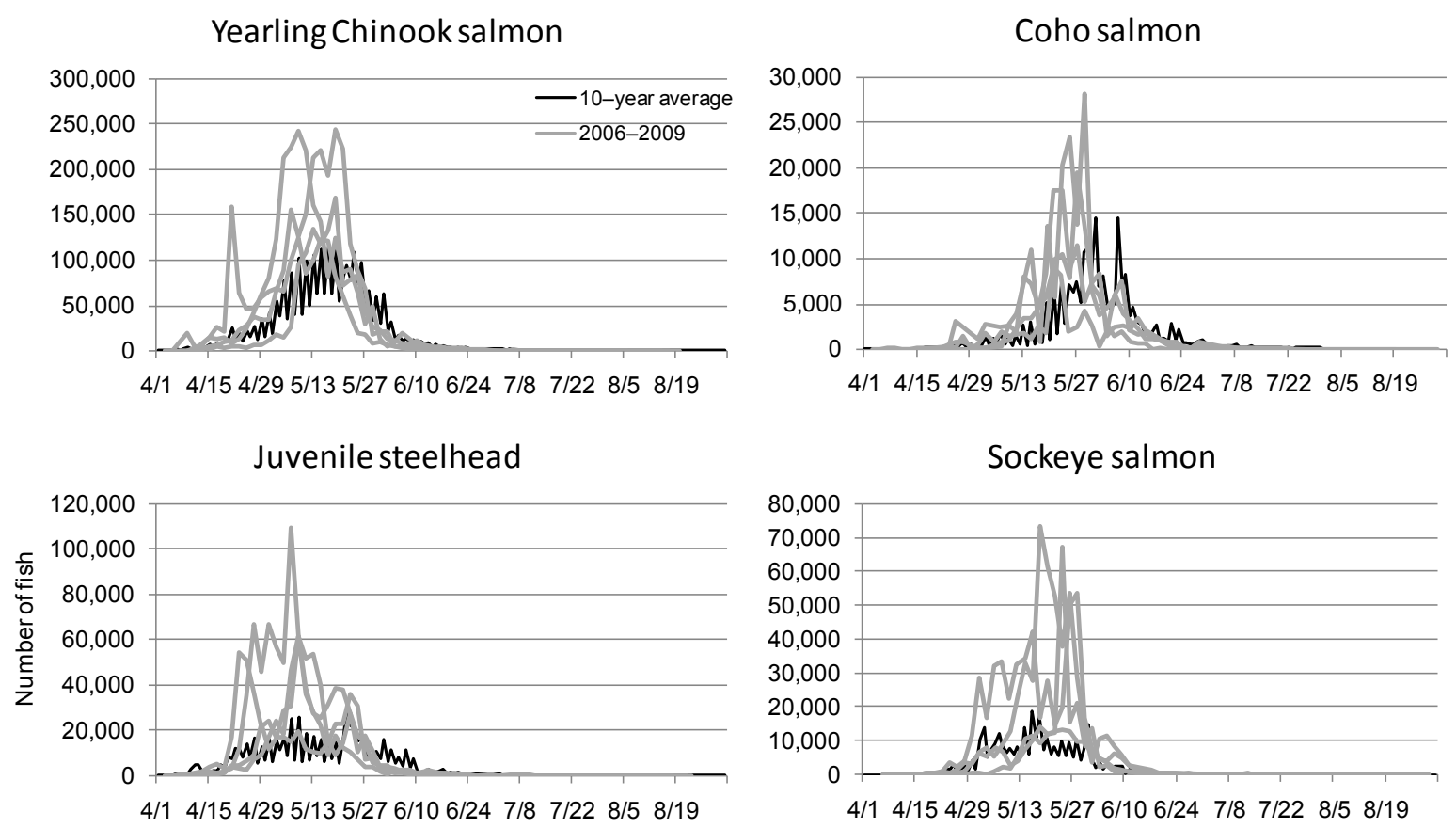

Subyearling Chinook salmon

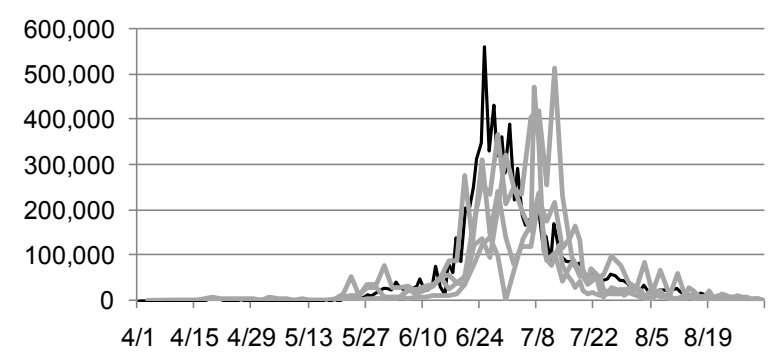

Figure 11. Run timing of yearling Chinook salmon, coho salmon, juvenile steelhead, sockeye salmon, and subyearling Chinook salmon through McNary Dam for the 10-year average (black line) and 2006-09 (gray lines). Data obtained from the Fish Passage Center (http://www.fpc.org.html). 


\section{Study Design}

\section{Acoustic Telemetry System}

The acoustic telemetry system consisted of acoustic receivers, hydrophones, and transmitters. All hydrophones (model 590; Hydroacoustic Technology, Inc. ${ }^{\circ}, \mathrm{HTI}^{\circ}$; Seattle, Wash.) had a $290^{\circ}$ beam width and were monitored continuously by either an acoustic telemetry receiver (ATR; model 290; $\mathrm{HTI}^{\odot}$ ) or an acoustic tag data logger (ATDL; model 295-X; $\mathrm{HTI}^{\odot}$ ). Depending on the year of study, 86113 hydrophones were linked to 5-7 ATRs and 17-20 ATDLs. In the forebay, hydrophones were mounted about $2 \mathrm{~m}$ below the water surface and near the bottom (greater than $18.3 \mathrm{~m}$ below the surface) of the river. Double hydrophone arrays were installed at all dam passage routes to permit the estimation of route-specific detection probabilities and use of the route-specific survival model (Skalski and others, 2002). At remote detection arrays located upstream and downstream of the dam, hydrophones were deployed on floating barges or pre-existing structures (for example, bridge pilings, navigation markers, and navigation walls) at depths of $1.5 \mathrm{~m}$ to $2.1 \mathrm{~m}$, depending on the location. At locations where surface-mounting was not feasible, hydrophones were deployed about $1 \mathrm{~m}$ above the river bottom using steel towers. Satellite or cellular modems were deployed at each hydrophone array to establish a wireless network between each ATDL or ATR, and our data processing servers at the Columbia River Research Laboratory. This network allowed automated transfer of data, as well as the ability to access and control each ATDL and ATR remotely. A detailed description of hydrophone arrays can be found in Adams and others (2008), Adams and Counihan (2009), and Adams and Liedtke (2009, 2010).

Although the same manufacturer and models of acoustic telemetry receiving equipment were used during all study years, and hydrophones were mounted to detect fish passing through any route, there were some differences in system deployment among years. Some of these differences were caused by changing locations of the TSWs, changing objectives or improving the detection performance of the hydrophones by locating them away from sources of noise. Appendix A portrays our acoustic telemetry system layout in each study year. However, some changes in deployment are not distinguishable on the plan views. One example includes the mounting of hydrophones $3 \mathrm{~m}$ lower on the spillway pier noses in 2007, 2008, and 2009 (compared to 2006) to decrease noise induced by flow at the spillway ogee. Another example, one that is distinguishable in appendix A, includes the different location of deep hydrophones at the powerhouse in 2009, compared to other years. In 2009, we deployed deep hydrophones on towers located $60 \mathrm{~m}$ in front of the powerhouse on the forebay floor, rather than using divers to mount the hydrophones directly to the powerhouse on the pier noses. This change was implemented at the request of the U.S. Army Corps of Engineers to reduce installation costs. In addition to reducing the cost, this change in deployment also reduced the amount of noise detected by the monitoring system and improved the performance of the system. 


\section{Transmitters}

We used acoustic transmitters that operated at a frequency of $307.5 \mathrm{kHz}$ with a $1.0-2.0 \mathrm{~ms}$ pulse width. Transmitter size and weight varied depending on the year of study and model of tag used (table 3). Each transmitter emitted a unique acoustic signal (encoded by pulse rate), allowing simultaneous monitoring of multiple transmitters by a single hydrophone. In addition to the acoustic transmitter, we inserted a PIT-tag (Destron-Fearing ${ }^{\mathrm{TM}}$ model TX1411ST) into each yearling and subyearling Chinook salmon and juvenile steelhead to enable determination of fish passage through the juvenile fish bypass system at McNary Dam. Sockeye salmon released by the mid-Columbia public utility districts (PUDs) were not implanted with PIT-tags. Each PIT-tag emitted a unique digitally encoded signal at $134.2 \mathrm{kHz}$ when activated by an electromagnetic field from a PIT-tag detector. Each PIT-tag weighed about $0.1 \mathrm{~g}$ in air. The additional weight and volume from the PIT-tag added a negligible amount of weight and volume to the fish relative to the acoustic transmitter.

Studies of the lifespan of acoustic tags were conducted by USGS in 2006, 2007, 2008, and 2009; CPUD in 2006, 2007, and 2008; and both CPUD and GPUD in 2009 (Adams and others, 2008; Adams and Counihan, 2009; Adams and Liedtke, 2009, 2010; Steig and others, 2007, 2008, 2009, 2010; Timko and others, 2010).These studies indicated the average lifespan was between 18 and $28 \mathrm{~d}$ for tags implanted in juvenile steelhead and yearling Chinook salmon and between 13 and $24 \mathrm{~d}$ for tags implanted in subyearling Chinook salmon, depending on tag model and year (table 3).

Table 3. Specifications of transmitters surgically implanted in juvenile salmonids, 2006-09.

[NA, not applicable]

\begin{tabular}{|c|c|c|c|c|c|c|}
\hline Year & Site & $\begin{array}{c}\text { Acoustic } \\
\text { transmitter model }\end{array}$ & $\begin{array}{c}\text { Average tag } \\
\text { dimensions } \\
\text { (millimeters) }\end{array}$ & $\begin{array}{l}\text { Average tag } \\
\text { weight in air } \\
\text { (grams) }\end{array}$ & $\begin{array}{l}\text { Average tag life } \\
\text { (days) }\end{array}$ & $\begin{array}{l}\text { PIT tag } \\
\text { model }\end{array}$ \\
\hline \multicolumn{7}{|c|}{ Yearling Chinook salmon and juvenile steelhead } \\
\hline 2006 & Columbia & $795-\mathrm{E}$ & $6.8 \times 21.0$ & 1.5 & 21 & TX1411ST \\
\hline 2007 & Columbia & $795-\mathrm{E}$ & $6.8 \times 21.0$ & 1.5 & 21 & TX1411ST \\
\hline 2008 & Columbia & 795-E & $7.1 \times 21.9$ & 1.6 & 18 & TX1411ST \\
\hline 2009 & Columbia & 795-LE & $6.7 \times 21.1$ & 1.4 & 28 & TX1411ST \\
\hline \multicolumn{7}{|c|}{ Subyearling Chinook salmon } \\
\hline 2006 & Columbia & 795-M & $6.8 \times 16.5$ & 0.8 & 17 & TX1411ST \\
\hline 2007 & Columbia & 795-M & $6.8 \times 16.5$ & 0.8 & 17 & TX1411ST \\
\hline 2008 & Columbia & 795-S & $6.5 \times 22.2$ & 0.7 & 13 & TX1411ST \\
\hline 2009 & Columbia & 795-LM & $6.5 \times 16.3$ & 0.7 & 24 & TX1411ST \\
\hline \multicolumn{7}{|c|}{ Sockeye salmon } \\
\hline 2006 & Mid-Columbia & 795-M & $6.8 \times 16.5$ & 0.8 & 14 & NA \\
\hline 2007 & Mid-Columbia & 795-M & $6.8 \times 16.5$ & 0.8 & 14 & NA \\
\hline 2008 & Mid-Columbia & 795-M & $6.8 \times 16.5$ & 0.8 & 17 & NA \\
\hline 2009 & Mid-Columbia & 795-Lm & $5.0 \times 17.5$ & 0.7 & 22 & NA \\
\hline
\end{tabular}




\section{Fish Tagging and Release}

All fish were tagged and released by personnel from USGS using methodology and protocols described by Adams and others (1998). The source, collection, and release sites for each species and release group are briefly documented in this report but detailed descriptions of collection, transport, and tagging procedures can be found in Adams and others (2008), Adams and Counihan (2009), and Adams and Liedtke $(2009,2010)$. Yearling and subyearling Chinook salmon and juvenile steelhead were collected, tagged, and held at the McNary Dam smolt monitoring facility operated by the Washington Department of Fish and Wildlife. For all experimental groups, handling protocols (regarding collection, transport, tagging, holding, and release) were standardized as much as possible among release groups to reduce the potential for bias arising from differences in handling methods and time. All acoustic transmitters were surgically implanted. Fish were held for 18 to $36 \mathrm{~h}$ before and after tagging to minimize stress associated with handling. The treatment release location was approximately $10 \mathrm{rkm}$ upstream of McNary Dam at Hat Rock State Park, Oregon; a distance upstream of the dam considered sufficient for allowing fish to mix naturally in the river before reaching the dam. Control groups were released in the tailrace of McNary Dam, directly out from the downstream tip of the navigation wall. Both treatment and control groups were released across the main channel in three locations (north, middle, and south of main river channel) to allow greater distribution in the river. To distribute fish arrival times at the dam, we released fish throughout the 24-h diel cycle. Species, release dates, release sites, passage dates, and percent spill during dates of passage are documented in tables 4 and 5 .

\section{Signal Processing and Verification}

Passage routes, approach distributions, and travel times were determined from acoustic transmitter signals collected by hydrophones at the dam and in the reservoir. Valid acoustic signals were separated from ambient noise using the HTIC MarkTags software. Files were then compiled and the auto-marking software identified individual tags to be verified by data technicians. Tracking parameters were set in the software to minimize the marking of false detections caused by noise or overlap of individual tags and to maximize detections of available fish (based on a tag list of all possible tags). Tag lists were generated for each batch based on a search duration determined by the estimated travel time information. Once fish records were verified by technicians, a second round of processing occurred with a wider parameter set and search duration and a smaller tag list to look for remaining undetected fish. All verified fish records were then compiled and detections of individual fish were identified and given to data technicians for manual marking of the individual tracks. After manual marking, the MarkTags software was used to assign a date and time for the beginning and end of each valid acoustic track. The detections were then used to estimate the proximity of an acoustic transmitter to hydrophones in the array and to estimate the 2-D and 3-D locations of the acoustic transmitters. 


\section{Results}

Results from the one-step Markov analysis will be presented first, followed by results from the two-step analysis. Within these sections, results will be presented for all fish regardless of where they first approached the dam, followed by all fish that first approached the powerhouse and then all fish that first approached the spillway. Differences between fish species and years will be presented within these sections. This report is the second report published in 2012 that utilizes this analytical method. The first report included only fish released as part of the annual studies conducted at McNary Dam in 2006-09. This second report includes sockeye salmon that were released as part of studies conducted by the Chelan and Grant County PUDs at mid-Columbia River dams. The studies conducted in the midColumbia used the same transmitters as were used for McNary Dam studies, but transmitter pulse width was different between studies. Additionally, no PIT tags were implanted in sockeye salmon. Differences in transmitter pulse width resulted in lower detection probabilities for sockeye salmon at McNary Dam. The absence of PIT tags prevented us from determining if fish passed the powerhouse through the JBS or turbines. To facilitate comparison among species in this report, we combined JBS and turbine passage for yearling Chinook salmon, steelhead, and subyearling Chinook salmon even though we were able to differentiate between passage through the JBS or turbines for these three species. Information on passage proportions through the JBS and turbines can be found in the first report.

A basic understanding of how the data are arranged in the tables will help interpret the results. Table 6 is an example of the how the results for the one-step analysis are presented. Particular attention should be given to the table caption to determine the year (2006, 2007, 2008, or 2009) and approach criteria (regardless of approach, first approach in the powerhouse, and first approach in the spillway) that is represented in the table. The "Area of Passage" in the first row of the table represents the states upstream of the dam starting in the southern powerhouse area (PH\#1) and continuing north to the end of the spillway. Within each area, the probability of passing the dam is shown for each species. In the example shown in table 6, 0.21 yearling Chinook salmon that entered the PH\#1 area passed the dam and the remaining 0.79 transitioned to other areas. Within the spillway area, the probabilities are cumulative, so the passage proportions can be summed to represent the proportion of fish that passed through all the routes within the spillway. It is important to understand that the probabilities are not cumulative across adjoining areas. For example, it is not appropriate to sum the passage proportions across the three powerhouse areas (the sum of $\mathrm{PH \# 1}$ at 0.21 , $\mathrm{PH} \# 2$ at 0.24 , and $\mathrm{PH} \# 3$ at 0.28 equaling 0.73 ) to represent a total proportion of fish passing the entire powerhouse. The superscript letters associated with each of the probabilities in the table represent the robustness of the estimate, with the letter "a" being the most robust (greater than 100 transitions were used to estimate the probability) and the letter "c" being the least (10-50 transitions were used to estimate the probabilities). Probabilities based on less than 10 transitions are represented by an asterisk (*) and were not presented in the tables. A back slash (/) is used to show that a passage alternative (for example, TSW) was not installed and therefore unavailable for fish to pass during that year. 
Table 4. Summary statistics of fork length and weight for acoustic-tagged juvenile salmonids released in the Columbia River by release site, 2006-09.

[Species: Y. Chinook, yearling Chinook salmon; Steelhead, juvenile steelhead; S. Chinook, subyearling Chinook salmon. Release site: HAT, Near Hat Rock State Park, Oregon, approximately $10 \mathrm{~km}$ upstream of McNary Dam; TAIL, 0.5 km downstream of McNary Dam in the tailrace directly out from the downstream tip of the navigation wall; SAC, intentionally sacrificed fish released at the TAIL release site; RC, Rocky Reach Collector; RR, Rocky Reach Dam; RH, Rock Island Hydro Park; RI, Rock Island Dam; WA, Wanapum Dam; WE, Wells Dam. N, number of fish; Min, minimum; Max, maximum]

\begin{tabular}{|c|c|c|c|c|c|c|c|c|c|}
\hline \multirow{2}{*}{$\begin{array}{l}\text { Species/ } \\
\text { age class }\end{array}$} & \multirow{2}{*}{$\begin{array}{l}\text { Release } \\
\text { site }\end{array}$} & \multirow{2}{*}{$\begin{array}{l}\text { Release } \\
\text { dates }\end{array}$} & \multirow[t]{2}{*}{$N$} & \multicolumn{3}{|c|}{$\begin{array}{c}\text { Fork length, } \\
\text { in millimeters }\end{array}$} & \multicolumn{3}{|c|}{ Weight, in grams } \\
\hline & & & & Mean & Min & Max & Mean & Min & Max \\
\hline \multicolumn{10}{|c|}{2006} \\
\hline Y. Chinook & HAT & $4 / 27-6 / 4$ & 1,797 & 149 & 125 & 179 & 31.7 & 23.0 & 59.5 \\
\hline Y. Chinook & TAIL & $4 / 27-6 / 4$ & 1,213 & 148 & 133 & 175 & 31.3 & 22.6 & 49.8 \\
\hline Y. Chinook & $\mathrm{SAC}$ & $4 / 30-6 / 1$ & 49 & 148 & 134 & 174 & 31.7 & 23.0 & 48.7 \\
\hline Steelhead & HAT & $4 / 27-6 / 1$ & 1,005 & 209 & 122 & 290 & 78.6 & 31.0 & 236.5 \\
\hline Steelhead & SAC & $5 / 4-5 / 31$ & 50 & 205 & 158 & 267 & 73.3 & 30.1 & 152.6 \\
\hline S. Chinook & HAT & $6 / 20-7 / 19$ & 1,794 & 120 & 104 & 155 & 17.5 & 12.5 & 44.8 \\
\hline S. Chinook & TAIL & $6 / 20-7 / 19$ & 1,191 & 120 & 108 & 158 & 17.4 & 13.5 & 44.9 \\
\hline S. Chinook & SAC & $6 / 22-7 / 11$ & 50 & 118 & 112 & 133 & 16.7 & 13.6 & 25.1 \\
\hline \multicolumn{10}{|c|}{2007} \\
\hline Y. Chinook & HAT & $4 / 19-6 / 7$ & 1,973 & 151 & 130 & 222 & 33.4 & 23.0 & 108.4 \\
\hline Y. Chinook & TAIL & $4 / 19-6 / 7$ & 1,310 & 151 & 133 & 206 & 33.5 & 23.0 & 78.8 \\
\hline Y. Chinook & SAC & $4 / 27-6 / 4$ & 53 & 151 & 135 & 179 & 33.2 & 23.7 & 49.9 \\
\hline Steelhead & HAT & $4 / 21-6 / 6$ & 1,118 & 215 & 160 & 292 & 84.6 & 27.4 & 207.7 \\
\hline Steelhead & $\mathrm{SAC}$ & $4 / 28-6 / 2$ & 50 & 223 & 178 & 279 & 93.4 & 43.7 & 166.8 \\
\hline S. Chinook & HAT & $6 / 20-7 / 25$ & 1,771 & 118 & 105 & 166 & 17.8 & 13.2 & 55.2 \\
\hline S. Chinook & TAIL & $6 / 20-7 / 25$ & 1,182 & 118 & 105 & 168 & 17.6 & 12.8 & 59.9 \\
\hline S. Chinook & $\mathrm{SAC}$ & $6 / 24-7 / 24$ & 50 & 118 & 110 & 136 & 17.8 & 13.5 & 32.5 \\
\hline \multicolumn{10}{|c|}{2008} \\
\hline Y. Chinook & HAT & $4 / 19-6 / 3$ & 1,424 & 154 & 131 & 206 & 36.0 & 23.0 & 147.6 \\
\hline Y. Chinook & TAIL & $4 / 20-6 / 4$ & 949 & 153 & 130 & 200 & 35.5 & 23.0 & 76.7 \\
\hline Y. Chinook & $\mathrm{SAC}$ & $4 / 22-5 / 31$ & 50 & 151 & 134 & 189 & 34.2 & 24.1 & 63.6 \\
\hline Steelhead & HAT & $4 / 19-6 / 2$ & 1,186 & 211 & 136 & 289 & 82.8 & 27.5 & 224.0 \\
\hline Steelhead & TAIL & $4 / 20-6 / 3$ & 785 & 210 & 135 & 294 & 81.7 & 25.0 & 232.7 \\
\hline Steelhead & SAC & $4 / 22-5 / 31$ & 50 & 213 & 171 & 270 & 87.2 & 38.3 & 179.2 \\
\hline S. Chinook & HAT & $6 / 19-7 / 28$ & 1,752 & 116 & 102 & 158 & 17.1 & 11.8 & 46.8 \\
\hline S. Chinook & TAIL & $6 / 20-7 / 29$ & 1,176 & 117 & 103 & 155 & 17.1 & 11.8 & 40.7 \\
\hline S. Chinook & SAC & $6 / 22-7 / 27$ & 50 & 117 & 107 & 142 & 17.4 & 12.4 & 33.3 \\
\hline \multicolumn{10}{|c|}{2009} \\
\hline Y. Chinook & HAT & $4 / 18-6 / 4$ & 1,411 & 164 & 134 & 240 & 44.4 & 29.0 & 119.0 \\
\hline Y. Chinook & TAIL & $4 / 18-6 / 4$ & 935 & 164 & 137 & 255 & 44.7 & 29.0 & 174.0 \\
\hline Y. Chinook & SAC & $4 / 20-5 / 29$ & 51 & 161 & 143 & 195 & 41.9 & 30.4 & 75.2 \\
\hline Steelhead & HAT & $4 / 18-6 / 4$ & 1,176 & 220 & 111 & 280 & 93.8 & 32.6 & 215.4 \\
\hline Steelhead & TAIL & $4 / 18-6 / 4$ & 785 & 220 & 158 & 283 & 94.7 & 32.4 & 218.0 \\
\hline Steelhead & SAC & $4 / 23-5 / 29$ & 51 & 216 & 156 & 254 & 87.4 & 31.5 & 130.0 \\
\hline S. Chinook & HAT & $6 / 20-7 / 30$ & 1,784 & 121 & 105 & 158 & 20.2 & 13.5 & 47.0 \\
\hline S. Chinook & TAIL & $6 / 20-7 / 30$ & 1,187 & 122 & 102 & 172 & 20.4 & 13.5 & 57.8 \\
\hline S. Chinook & $\mathrm{SAC}$ & $6 / 25-7 / 28$ & 51 & 118 & 109 & 148 & 18.8 & 14.0 & 38.2 \\
\hline
\end{tabular}


Table 5. Number of acoustic-tagged juvenile salmonids released in the Columbia River, number (and percent of those released) that passed McNary Dam, range of passage dates, and corresponding percent spill of total project discharge over dates of passage at McNary Dam, by species, 2006-09.

[Y. Chinook, yearling Chinook salmon; Steelhead, juvenile steelhead; S. Chinook, subyearling Chinook salmon]

\begin{tabular}{|c|c|c|c|c|c|}
\hline Species & $\begin{array}{l}\text { Number } \\
\text { released }\end{array}$ & $\begin{array}{c}\text { Number (\%) } \\
\text { passed }\end{array}$ & $\begin{array}{c}\text { First passage } \\
\text { date }\end{array}$ & $\begin{array}{l}\text { Last passage } \\
\text { date }\end{array}$ & Percent spill $^{1}$ \\
\hline \multicolumn{6}{|c|}{2006} \\
\hline Y. Chinook & 1,797 & $1,717(96)$ & $4 / 27 / 2006$ & $6 / 5 / 2006$ & 50 \\
\hline Steelhead & 1,005 & $944(94)$ & $4 / 27 / 2006$ & $6 / 2 / 2006$ & 48 \\
\hline S. Chinook & 1,791 & $1,638(91)$ & $6 / 20 / 2006$ & $7 / 30 / 2006$ & 49 \\
\hline Sockeye & 3,493 & $1,339(38)$ & $5 / 10 / 2006$ & $6 / 11 / 2006$ & 52 \\
\hline \multicolumn{6}{|l|}{2007} \\
\hline Y. Chinook & 1,974 & $1,911(97)$ & $4 / 20 / 2007$ & $6 / 9 / 2007$ & 43 \\
\hline Steelhead & 1,118 & $1,086(97)$ & $4 / 22 / 2007$ & 6/9/2007 & 41 \\
\hline S. Chinook & 1,771 & $1,631(92)$ & $6 / 21 / 2007$ & $8 / 7 / 2007$ & 52 \\
\hline Sockeye & 2,500 & $1,224(49)$ & $5 / 11 / 2007$ & $6 / 14 / 2007$ & 41 \\
\hline \multicolumn{6}{|c|}{2008} \\
\hline Y. Chinook & 1,424 & $1,396(98)$ & $4 / 19 / 2008$ & $6 / 8 / 2008$ & 46 \\
\hline Steelhead & 1,186 & $1,186(100)$ & $4 / 19 / 2008$ & $6 / 3 / 2008$ & 47 \\
\hline S. Chinook & 1,752 & $1,646(94)$ & $6 / 20 / 2008$ & $8 / 8 / 2008$ & 51 \\
\hline Sockeye & 2,002 & $1,084(54)$ & $5 / 18 / 2008$ & $6 / 21 / 2008$ & 57 \\
\hline \multicolumn{6}{|c|}{2009} \\
\hline Y. Chinook & 1,403 & $1,351(96)$ & $4 / 18 / 2009$ & $6 / 8 / 2009$ & 44 \\
\hline Steelhead & 1,170 & $1,107(95)$ & 4/19/2009 & $6 / 4 / 2009$ & 43 \\
\hline S. Chinook & 1,772 & $1,602(90)$ & $6 / 20 / 2009$ & $8 / 7 / 2009$ & 51 \\
\hline Sockeye & 3,974 & $3,578(90)$ & $5 / 18 / 2009$ & $6 / 20 / 2009$ & 50 \\
\hline
\end{tabular}

${ }^{1}$ The percentage of project discharge spilled includes the water discharged through the temporary spillway weirs.

Table 6. Percentage of fish passing McNary Dam during day and night periods in 2006 based on a one-step Markov Chain analysis.

[Data represent all fish regardless of where they first approached the dam and include both day and night periods. Species: YCH, Yearling Chinook salmon; STH, juvenile steelhead; SCH, subyearling Chinook salmon; SOC, Sockeye salmon; Area of Passage: PH\#1, turbine units 1-5; PH\#2, turbine units 6-10; PH\#3, turbine units 11-14; Spillway, spill bays 1-22; TSW, temporary spillway weir; ( () denotes the TSW was not installed; Superscripts denote number of transitions used to calculate percentage: ${ }^{\mathrm{a}}$, greater than $100 ;{ }^{\mathrm{b}}, 50-100 ;^{\mathrm{c}}, 10$ to $50 ;(*)$, less than 10 , which was insufficient sample size to calculate percentage]

\begin{tabular}{cc|c|c|cccc}
\hline & & \multicolumn{9}{c}{ Area of Passage } \\
Species & PH \#1 & PH \#2 & PH \#3 & \multicolumn{4}{c}{ Spillway } \\
\cline { 2 - 7 } YCH & $21^{\mathrm{a}}$ & $24^{\mathrm{a}}$ & $28^{\mathrm{a}}$ & $\underline{\text { TSW 22 }}$ & $\underline{\text { TSW 20 }}$ & $\underline{\text { Bays }}$ & $\underline{\text { TSW 4 }}$ \\
STH & $14^{\mathrm{a}}$ & $7^{\mathrm{a}}$ & $7^{\mathrm{a}}$ & $\backslash$ & $\backslash$ & $96^{\mathrm{a}}$ & $\backslash$ \\
SCH & $21^{\mathrm{a}}$ & $17^{\mathrm{a}}$ & $14^{\mathrm{a}}$ & $\backslash$ & $\backslash$ & $85^{\mathrm{a}}$ & $\backslash$ \\
SOC & $28^{\mathrm{a}}$ & $44^{\mathrm{a}}$ & $47^{\mathrm{b}}$ & $\backslash$ & 1 & $83^{\mathrm{c}}$ & $\backslash$ \\
\hline
\end{tabular}


The presentation of results for the two-step analysis is very similar to that of the one-step analysis. The main difference is where the fish was located before it either passed through an area or transitioned to the next area. For example, table 7 shows that 0.66 of steelhead passed through the spillway area after transitioning to the spillway from the PH\#3. Slightly less, 0.61, of steelhead passed the spillway after transitioning directly from the forebay into the spillway. When interpreting the results from the two-step analysis, it also is important to note from the table title where the fish first approached the dam. For example, for fish that first approached the powerhouse, there will be no data in the tables for fish that passed the spillway after transitioning from the forebay because only the fish that were first detected in the powerhouse are included in the table. The same is true for fish that first approached the spillway. There are no data in the tables for fish that passed any of the powerhouse areas after transitioning from the forebay because only the fish that first approached the spillway are included in the table. For completeness, the tables include all columns for fish approaching from the forebay but table cells have an "NA" (not applicable) for passage areas different than approach area. The two-step analysis allowed us to investigate how the transitions from one state depended on which state the fish was in previously.

\section{One-Step Markov Chain Results}

\section{Transition Probabilities Regardless of Area of First Detection}

In 2006, the highest percentage of fish transitioning through a passage route occurred in the spillway (table 6). For yearling Chinook salmon, 0.96 of fish that entered the spillway area passed through the spillway and the remaining 0.04 of the fish transitioned to other areas upstream of the dam before passing. For steelhead, 0.65 of the fish that entered the spillway area passed the spillway. About the same proportion of subyearling Chinook salmon (0.80) and sockeye salmon (0.83) that entered the spillway area also passed the spillway with the remainder transitioning to other areas upstream of the dam before passing.

Within the powerhouse, transitions into passage routes were lowest for steelhead compared to the other three species. Only $0.07-0.14$ of steelhead that entered one of the three areas in the powerhouse passed into either the JBS or turbines. The remaining $0.86-0.93$ of steelhead transitioned to an adjoining area before passing the dam. Compared to steelhead, more yearling Chinook salmon (0.210.28) passed the powerhouse through either the JBS or turbines. Similarly, 0.14-0.21 of subyearling Chinook salmon passed the powerhouse. Compared to the other three species, sockeye salmon had the highest passage proportions through all three areas in the powerhouse $(0.28-0.47)$

The operation of the TSWs in bays 22 and 20 during 2007 influenced passage probabilities in the spillway (table 8). After entering the spillway area, the proportion of fish passing through all routes in the spillway area remained nearly the same for yearling Chinook salmon in 2007 (0.92), compared to 2006 (0.96), however, their route of passage within the spillway area changed substantially. After entering the spillway area, the proportion of fish that passed though the bays in this area decreased from 0.96 in 2006 to 0.41 in 2007, but the proportion that passed through both TSWs was 0.51 . The proportion of steelhead passing through all routes in the spillway area increased from 0.65 in 2006 to 0.83 in 2007 for steelhead. Likewise, passage for Subyearling Chinook salmon in the spillway increased from 0.80 in 2006 to 0.87 in 2007 . However, passage for sockeye salmon for all routes combined in the spillway decreased from 0.83 in 2006 to 0.64 in 2007. Of the two TSWs, the one in bay 22 passed a higher proportion of fish, thereby decreasing the proportion of fish that transitioned to other areas of the dam before passing. 
Table 7. Percentage of fish passing McNary Dam during day and night periods in 2006 based on a two-step Markov Chain analysis.

[Data represent all fish regardless of where they first approached the dam and include both day and night periods. Species: YCH, Yearling Chinook salmon; STH, juvenile steelhead; SCH, subyearling Chinook salmon; SOC, Sockeye salmon; Area of Passage: PH\#1, turbine units 1-5; PH\#2, turbine units 6-10; PH\#3, turbine units 11-14; Spillway, spill bays 1-22; TSW, temporary spillway weir; ( ) denotes the TSW was not installed; Superscripts denote number of transitions used to calculate percentage: ${ }^{\text {a }}$, greater than $100 ;{ }^{b}, 50-100 ;{ }^{c}, 10$ to $50 ;(*)$, less than 10 , which was insufficient sample size to calculate percentage]

\begin{tabular}{|c|c|c|c|c|c|c|c|c|c|c|c|c|c|c|c|c|c|}
\hline $\begin{array}{c}\text { Area of } \\
\text { Passage: }\end{array}$ & \multicolumn{3}{|c|}{$\mathrm{PH} \# 1$} & \multicolumn{3}{|c|}{$\mathrm{PH} \# 2$} & \multicolumn{3}{|c|}{$\mathrm{PH} \# 3$} & \multicolumn{8}{|c|}{ Spillway } \\
\hline \multirow[b]{2}{*}{$\underline{\text { Species }}$} & $\begin{array}{l}\text { passing } \\
\text { PH\#1 } \\
\text { after } \\
\text { coming } \\
\text { from }\end{array}$ & $\begin{array}{l}\text { passing } \\
\mathrm{PH \# 1} \\
\text { after } \\
\text { coming } \\
\text { from }\end{array}$ & $\begin{array}{l}\text { passing } \\
\text { PH\#1 } \\
\text { after } \\
\text { coming } \\
\text { from }\end{array}$ & $\begin{array}{l}\text { passing } \\
\text { PH\#2 } \\
\text { after } \\
\text { coming } \\
\text { from }\end{array}$ & $\begin{array}{l}\text { passing } \\
\text { PH\#2 } \\
\text { after } \\
\text { coming } \\
\text { from }\end{array}$ & $\begin{array}{l}\text { passing } \\
\text { PH\#2 } \\
\text { after } \\
\text { coming } \\
\text { from }\end{array}$ & $\begin{array}{l}\text { passing } \\
\text { PH\#3 } \\
\text { after } \\
\text { coming } \\
\text { from }\end{array}$ & $\begin{array}{l}\text { passing } \\
\text { PH\#3 } \\
\text { after } \\
\text { coming } \\
\text { from }\end{array}$ & $\begin{array}{l}\text { passing } \\
\text { PH\#3 } \\
\text { after } \\
\text { coming } \\
\text { from }\end{array}$ & $\begin{array}{l}\text { passi } \\
\text { comir }\end{array}$ & $\begin{array}{l}\text { spillv } \\
\text { from }\end{array}$ & $\begin{array}{l}\text { y after } \\
\text { H\#3 }\end{array}$ & & $\begin{array}{l}\text { passi } \\
\text { comir }\end{array}$ & $\begin{array}{l}\text { g spillw } \\
\text { from } f\end{array}$ & $\begin{array}{l}\text { yy after } \\
\text { rebay }\end{array}$ & \\
\hline & & & & & & & & & & $\frac{\text { TSW }}{\underline{22}}$ & $\frac{\text { TSW }}{\underline{20}}$ & Bays & $\frac{\text { TSW }}{\underline{4}}$ & $\frac{\text { TSW }}{\underline{22}}$ & $\frac{\text { TSW }}{\underline{20}}$ & Bays & $\frac{\mathrm{TSW}}{\underline{4}}$ \\
\hline $\mathrm{YCH}$ & $24^{\mathrm{a}}$ & $39^{\mathrm{a}}$ & $11^{\mathrm{a}}$ & $16^{\mathrm{a}}$ & $48^{\mathrm{a}}$ & $17^{\mathrm{a}}$ & $21^{\mathrm{a}}$ & $44^{\mathrm{a}}$ & $6^{\mathrm{c}}$ & 1 & 1 & $95^{\mathrm{a}}$ & 1 & 1 & 1 & $96^{\mathrm{a}}$ & 1 \\
\hline STH & $12^{\mathrm{b}}$ & $26^{\mathrm{a}}$ & $9^{a}$ & $5^{a}$ & $20^{\mathrm{a}}$ & $4^{\mathrm{a}}$ & $4^{\mathrm{a}}$ & $22^{\mathrm{a}}$ & $8^{\mathrm{a}}$ & 1 & 1 & $66^{\mathrm{a}}$ & 1 & 1 & 1 & $61^{\mathrm{a}}$ & 1 \\
\hline $\mathrm{SCH}$ & $23^{\mathrm{a}}$ & $33^{\mathrm{a}}$ & $16^{\mathrm{a}}$ & $16^{\mathrm{a}}$ & $26^{\mathrm{a}}$ & $14^{\mathrm{a}}$ & $11^{\mathrm{a}}$ & $23^{\mathrm{a}}$ & $6^{\mathrm{b}}$ & 1 & 1 & $92^{\mathrm{a}}$ & 1 & 1 & 1 & $46^{\mathrm{b}}$ & 1 \\
\hline $\mathrm{SOC}$ & $*$ & $14^{\mathrm{b}}$ & $51^{\mathrm{c}}$ & $46^{\mathrm{b}}$ & $46^{\mathrm{b}}$ & $34^{\mathrm{c}}$ & $49^{b}$ & $43^{c}$ & $*$ & 1 & 1 & $100^{c}$ & 1 & 1 & 1 & $*$ & 1 \\
\hline
\end{tabular}


Table 8. Percentage of fish passing McNary Dam during day and night periods in 2007 based on a one-step Markov Chain analysis.

[Data represent all fish regardless of where they first approached the dam and include both day and night periods. Species: YCH, Yearling Chinook salmon; STH, juvenile steelhead; SCH, subyearling Chinook salmon; SOC, Sockeye salmon. Area of Passage: PH\#1, turbine units 1-5; PH\#2, turbine units 6-10; PH\#3, turbine units 11-14; Spillway, spill bays 1-22; TSW, temporary spillway weir; ( () denotes the TSW was not installed; Superscripts denote number of transitions used to calculate percentage: ${ }^{\mathrm{a}}$, greater than $100 ;{ }^{\mathrm{b}}, 50-100 ;{ }^{\mathrm{c}}, 10$ to $50 ;(*)$, less than 10 , which was insufficient sample size to calculate percentage]

\begin{tabular}{cc|c|c|cccc}
\hline & & \multicolumn{9}{c}{ Area of Passage } \\
Species & PH \#1 & PH \#2 & PH \#3 & \multicolumn{4}{c}{ Spillway } \\
\cline { 2 - 7 } YCH & $22^{\mathrm{a}}$ & $27^{\mathrm{a}}$ & $18^{\mathrm{a}}$ & $\frac{\text { TSW 22 }}{37^{\mathrm{a}}}$ & $\underline{\text { TSW 20 }}$ & $\frac{\text { Bays }}{44^{\mathrm{a}}}$ & $\underline{\text { TSW 4 }}$ \\
STH & $6^{\mathrm{a}}$ & $4^{\mathrm{a}}$ & $4^{\mathrm{a}}$ & $51^{\mathrm{a}}$ & $18^{\mathrm{a}}$ & $14^{\mathrm{a}}$ & $\backslash$ \\
SCH & $22^{\mathrm{a}}$ & $21^{\mathrm{a}}$ & $14^{\mathrm{a}}$ & $42^{\mathrm{a}}$ & $19^{\mathrm{a}}$ & $26^{\mathrm{a}}$ & $\backslash$ \\
SOC & $37^{\mathrm{a}}$ & $39^{\mathrm{a}}$ & $24^{\mathrm{a}}$ & $36^{\mathrm{b}}$ & $19^{\mathrm{b}}$ & $9^{\mathrm{b}}$ & $\backslash$ \\
\hline
\end{tabular}

After entering one of the three areas upstream of the powerhouse, the probability of passing the powerhouse in 2007 was similar to 2006 for all species (table 8). Once again, the probability of passing the powerhouse was lower for steelhead compared to the other species. As was the case in 2006, sockeye salmon had the highest passage probabilities in the powerhouse areas compared to the other three species.

The relocation of the TSW during 2008 from bay 22 to bay 19 affected passage probabilities in the spillway area. After fish entered the spillway area, overall passage proportions through this area decreased by about 0.05 to 0.64 and the proportions passing through both TSWs combined decreased in 2008 compared to 2007 (table 9). The combined passage probabilities for the two TSWs decreased from 0.51 to 0.47 for yearling Chinook salmon, from 0.69 to 0.47 for steelhead, from 0.61 to 0.38 for subyearling Chinook salmon, and from 0.55 to 0.00 for sockeye salmon. Detection probabilities were low for sockeye salmon in the spillway due to differences in the way the signal was coded for the tags released as part of the mid-Columbia studies. The coding of the tags was not optimized for passage at McNary Dam and likely accounted for the dramatic reduction in TSW passage observed in 2008. Of the yearling Chinook salmon that entered the spillway area, the proportion that passed through the bays decreased from 0.41 in 2007 to 0.33 in 2008 . For steelhead, passage through the bays increased from 0.14 to 0.22 . Similarly, subyearling Chinook salmon had higher passage proportions through the bays in 2008 (0.44) compared to 2007 (0.26). Passage proportions through the bays for sockeye salmon remained consistently low in 2007 (0.09) and 2008 (0.10), likely due to low detection probabilities of the tags used in this species, especially when fish were in the spillway. Trends in passage probabilities in the powerhouse remained constant in 2008 compared to the two previous years.

In 2009, changes in the locations of the TSWs resulted in changes in the passage proportions in the spillway. During the spring study period, one TSW was located in bay 20, and the other was located in bay 4. With only one TSW in the southern part of the spillway, the area closest to the powerhouse, the combined passage probability through both TSWs decreased and the passage through the bays increased. For yearling Chinook salmon, 0.47 passed through the two TSWs in 2008 compared to only 0.23 in 2009. Passage through the bays increased for yearling Chinook salmon from 0.33 in 2008 to 
0.64 in 2009 (table 10). A similar trend was observed for steelhead. Less of the steelhead passed through the two TSWs combined in 2009 (0.39) compared to 2008 (0.47). Like yearling Chinook salmon, more steelhead passed through the bays in 2009 compared to 2008 and contributed to an overall increase in spillway passage in 2009 (0.76) compared to 2008 (0.69). During the summer study period, the TSW located in bay 4 was moved to bay 19 resulting in two TSWs within the southern spillway area, similar to 2007 and 2008. Passage probability through all routes in the spillway area remained relatively high for subyearling Chinook salmon in 2009 (0.91), which was similar to 2008 (0.82) and 2007 (0.87). Passage probabilities for sockeye salmon were variable across the study years, likely due to the differences in the way tags were programmed to emit the signal. Passage probability in the spillway was high in 2009 (0.97), low in 2008 (0.10), and moderately high in 2007 (0.64).

Regardless of where fish first approached the dam, there were differences in passage probabilities during the day and night, especially after fish entered one of the three areas upstream of the powerhouse. The trends varied among the three species and across the 4 years included in the analysis. The passage trends in the spillway remained about the same during the day and night. The results of the one-step analysis for all fish, regardless of where they first approached the dam, during the day and night are presented in appendix B. The effect of diel period on passage probabilities is discussed in more detail in the section describing transition probabilities during day and night for fish that first approached the powerhouse and first approached the spillway.

Table 9. Percentage of fish passing McNary Dam during day and night periods in 2008 based on a one-step Markov Chain analysis.

[Data represent all fish regardless of where they first approached the dam and include both day and night periods. Species: YCH, Yearling Chinook salmon; STH, juvenile steelhead; SCH, subyearling Chinook salmon; SOC, Sockeye salmon. Area of Passage: PH\#1, turbine units 1-5; PH\#2, turbine units 6-10; PH\#3, turbine units 11-14; Spillway, spill bays 1-22; TSW, temporary spillway weir; ( $($ ) denotes the TSW was not installed; Superscripts denote number of transitions used to calculate percentage: ${ }^{\mathrm{a}}$, greater than $100 ;{ }^{\mathrm{b}}, 50-100 ;{ }^{\mathrm{c}}, 10$ to $50 ;(*)$, less than 10 , which was insufficient sample size to calculate percentage]

\begin{tabular}{cc|c|c|cccc}
\hline & & \multicolumn{9}{c}{ Area of Passage } \\
Species & PH \#1 & PH \#2 & PH \#3 & \multicolumn{4}{c}{ Spillway } \\
\cline { 2 - 7 } & & & & $\underline{T S W} 19$ & $\underline{\text { Bays }}$ & $\underline{\text { TSW 4 }}$ \\
YCH & $20^{\mathrm{a}}$ & $21^{\mathrm{a}}$ & $23^{\mathrm{a}}$ & $23^{\mathrm{a}}$ & $24^{\mathrm{a}}$ & $33^{\mathrm{a}}$ & $\backslash$ \\
STH & $12^{\mathrm{a}}$ & $7^{\mathrm{a}}$ & $10^{\mathrm{a}}$ & $30^{\mathrm{a}}$ & $17^{\mathrm{a}}$ & $22^{\mathrm{a}}$ & $\backslash$ \\
SCH & $22^{\mathrm{a}}$ & $16^{\mathrm{a}}$ & $16^{\mathrm{a}}$ & $20^{\mathrm{a}}$ & $18^{\mathrm{a}}$ & $44^{\mathrm{a}}$ & $\backslash$ \\
SOC & $39^{\mathrm{c}}$ & $83^{\mathrm{b}}$ & $35^{\mathrm{c}}$ & $0^{\mathrm{c}}$ & $0^{\mathrm{c}}$ & $100^{\mathrm{c}}$ & $\backslash$ \\
\hline
\end{tabular}


Table 10. Percentage of fish passing McNary Dam during day and night periods in 2009 based on a one-step Markov Chain analysis.

[Data represent all fish regardless of where they first approached the dam and include both day and night periods. Species: YCH, Yearling Chinook salmon; STH, juvenile steelhead; SCH, subyearling Chinook salmon; SOC, Sockeye salmon. Area of Passage: PH\#1, turbine units 1-5; PH\#2, turbine units 6-10; PH\#3, turbine units 11-14; Spillway, spill bays 1-22; TSW, temporary spillway weir; ( () denotes the TSW was not installed; Superscripts denote number of transitions used to calculate percentage: ${ }^{\mathrm{a}}$, greater than $100 ;{ }^{\mathrm{b}}, 50-100 ;{ }^{\mathrm{c}}, 10$ to $50 ;(*)$, less than 10 , which was insufficient sample size to calculate percentage]

\begin{tabular}{|c|c|c|c|c|c|c|c|}
\hline \multicolumn{8}{|c|}{ Area of Passage } \\
\hline \multirow[b]{2}{*}{ Species } & $\mathrm{PH} \# 1$ & $\mathrm{PH} \# 2$ & $\mathrm{PH} \# 3$ & \multicolumn{4}{|c|}{ Spillway } \\
\hline & & & & $\underline{\text { TSW } 20}$ & $\underline{\text { TSW } 19}$ & $\underline{\text { Bays }}$ & $\underline{\text { TSW } 4}$ \\
\hline $\mathrm{YCH}$ & $20^{\mathrm{a}}$ & $17^{\mathrm{a}}$ & $28^{\mathrm{a}}$ & $16^{\mathrm{a}}$ & 1 & $64^{\mathrm{a}}$ & $7^{\mathrm{a}}$ \\
\hline STH & $11^{\mathrm{a}}$ & $8^{\mathrm{a}}$ & $9^{\mathrm{a}}$ & $28^{\mathrm{a}}$ & 1 & $37^{\mathrm{a}}$ & $11^{\mathrm{a}}$ \\
\hline $\mathrm{SCH}$ & $16^{\mathrm{a}}$ & $11^{\mathrm{a}}$ & $29^{\mathrm{a}}$ & $19^{\mathrm{a}}$ & $16^{\mathrm{a}}$ & $56^{\mathrm{a}}$ & 1 \\
\hline SOC & $30^{\mathrm{a}}$ & $31^{\mathrm{a}}$ & $26^{\mathrm{a}}$ & $28^{\mathrm{a}}$ & 1 & $63^{\mathrm{a}}$ & $6^{\mathrm{a}}$ \\
\hline
\end{tabular}

\section{Transition Probabilities after First Approaching the Powerhouse}

The area in which a fish first approached the dam influenced passage probabilities. During 2006, fish that first approached the powerhouse and subsequently entered one of the three areas upstream of the powerhouse had passage probabilities between 0.06 and 0.48 through the JBS and turbines combined, with the remaining 0.52 to 0.94 of the fish transitioning to adjoining areas (table 11). Between 0.66 and 1.00 of the fish that transitioned to the spillway after approaching the powerhouse passed through the bays in the spillway area.

The installation of the TSWs in 2007 increased passage probabilities in the spillway area. After first approaching the powerhouse, passage probabilities in the spillway increased by 0.03 for yearling Chinook salmon and 0.23 for steelhead, but decreased 0.01 for subyearling Chinook salmon and 0.15 for sockeye salmon (table 12). The majority of the yearling Chinook salmon that passed the dam in 2007 after entering the spillway area did so through the TSW in bay 22 (0.78). Relatively few (0.07) passed through the TSW in bay 20 or the other bays in the spillway area (0.13). Passage for steelhead increased from 0.66 in 2006 to 0.89 in 2007 with the majority (0.69) passing through the TSW in bay 22. A similar pattern was observed for subyearling Chinook salmon. Total passage through all routes in the spillway area was about the same in 2006 (0.92) and 2007 (0.91) and the majority (0.56) of fish passed through the TSW in bay 22 but a smaller proportion passed through the TSW in bay $20(0.14)$. As previously mentioned, results for sockeye salmon were variable across the study years. However, passage through the TSWs for sockeye salmon was similar to the other species. In 2007, the passage probability for sockeye salmon was higher for TSW 22 (0.73) compared to TSW 20 (0.19). Moving the TSW in 2008 from bay 22 to bay 19 had an affected on passage probabilities in the spillway area for fish that were first detected in the powerhouse. Passage probabilities were relatively high in 2008 compared to 2006, but not as high as the probabilities observed in 2007 (table 13). 


\section{Table 11. Percentage of fish passing McNary Dam during day and night periods in 2006 based on a one-step Markov Chain analysis.}

[Data represent all fish that first approached the powerhouse and include both day and night periods. Species: YCH, Yearling Chinook salmon; STH, juvenile steelhead; SCH, subyearling Chinook salmon; SOC, Sockeye salmon. Area of Passage: PH\#1, turbine units 1-5; PH\#2, turbine units 6-10; PH\#3, turbine units 11-14; Spillway, spill bays 1-22; TSW, temporary spillway weir; $(\backslash)$ denotes the TSW was not installed; Superscripts denote number of transitions used to calculate percentage: ${ }^{\mathrm{a}}$, greater than $100 ;{ }^{\mathrm{b}}, 50-100 ;{ }^{\mathrm{c}}, 10$ to $50 ;\left(^{*}\right)$, less than 10, which was insufficient sample size to calculate percentage]

\begin{tabular}{|c|c|c|c|c|c|c|c|}
\hline \multicolumn{8}{|c|}{ Area of Passage } \\
\hline \multirow[b]{2}{*}{ Species } & $\mathrm{PH} \# 1$ & $\mathrm{PH} \# 2$ & $\mathrm{PH} \# 3$ & \multicolumn{4}{|c|}{ Spillway } \\
\hline & & & & $\underline{\text { TSW } 22}$ & $\underline{\text { TSW } 20}$ & $\underline{\text { Bays }}$ & $\underline{\text { TSW } 4}$ \\
\hline $\mathrm{YCH}$ & $21^{\mathrm{a}}$ & $24^{\mathrm{a}}$ & $29^{\mathrm{a}}$ & 1 & 1 & $95^{\mathrm{a}}$ & 1 \\
\hline STH & $13^{\mathrm{a}}$ & $7^{\mathrm{a}}$ & $6^{\mathrm{a}}$ & 1 & 1 & $66^{\mathrm{a}}$ & 1 \\
\hline $\mathrm{SCH}$ & $21^{\mathrm{a}}$ & $18^{\mathrm{a}}$ & $15^{\mathrm{a}}$ & 1 & 1 & $92^{\mathrm{a}}$ & 1 \\
\hline SOC & $28^{\mathrm{a}}$ & $45^{\mathrm{a}}$ & $48^{\mathrm{b}}$ & 1 & 1 & $100^{\mathrm{c}}$ & 1 \\
\hline
\end{tabular}

Table 12. Percentage of fish passing McNary Dam during 2007 based on a one-step Markov Chain analysis.

[Data represent all fish that first approached the powerhouse and include both day and night periods. Species: YCH, Yearling Chinook salmon; STH, juvenile steelhead; SCH, subyearling Chinook salmon; SOC, Sockeye salmon. Area of Passage: PH\#1, turbine units 1-5; PH\#2, turbine units 6-10; PH\#3, turbine units 11-14; Spillway, spill bays 1-22; TSW, Temporary spillway weir; ( $\backslash$ denotes the TSW was not installed; Superscripts denote number of transitions used to calculate percentage: ${ }^{\mathrm{a}}$, greater than $100 ;{ }^{\mathrm{b}}, 50-100 ;{ }^{\mathrm{c}}, 10$ to $50 ;(*)$, less than 10 , which was insufficient sample size to calculate percentage]

\begin{tabular}{|c|c|c|c|c|c|c|c|}
\hline \multicolumn{8}{|c|}{ Area of Passage } \\
\hline \multirow[b]{2}{*}{ Species } & \multirow[t]{2}{*}{$\mathrm{PH} \# 1$} & \multirow[t]{2}{*}{$\mathrm{PH} \# 2$} & \multirow[t]{2}{*}{$\mathrm{PH} \# 3$} & \multicolumn{4}{|c|}{ Spillway } \\
\hline & & & & TSW 22 & $\underline{\text { TSW } 20}$ & Bays & TSW 4 \\
\hline $\mathrm{YCH}$ & $22^{\mathrm{a}}$ & $27^{\mathrm{a}}$ & $19^{\mathrm{a}}$ & $78^{\mathrm{a}}$ & $7^{\mathrm{a}}$ & $13^{\mathrm{a}}$ & 1 \\
\hline STH & $6^{\mathrm{a}}$ & $4^{a}$ & $4^{a}$ & $69^{\mathrm{a}}$ & $13^{\mathrm{a}}$ & $7^{\mathrm{a}}$ & 1 \\
\hline $\mathrm{SCH}$ & $22^{\mathrm{a}}$ & $22^{\mathrm{a}}$ & $14^{\mathrm{a}}$ & $56^{\mathrm{a}}$ & $14^{\mathrm{a}}$ & $21^{\mathrm{a}}$ & 1 \\
\hline $\mathrm{SOC}$ & $37^{\mathrm{a}}$ & $39^{\mathrm{a}}$ & $19^{\mathrm{a}}$ & $54^{\mathrm{c}}$ & $19^{\mathrm{c}}$ & $12^{\mathrm{c}}$ & 1 \\
\hline
\end{tabular}


Table 13. Percentage of fish passing McNary Dam during day and night periods in 2008 based on a one-step Markov Chain analysis.

[Data represent all fish that first approached the powerhouse and include both day and night periods. Species: YCH, Yearling Chinook salmon; STH, juvenile steelhead; SCH, subyearling Chinook salmon; SOC, Sockeye salmon. Area of Passage: PH\#1, turbine units 1-5; PH\#2, turbine units 6-10; PH\#3, turbine units 11-14; Spillway, spill bays 1-22; TSW, temporary spillway weir; ( () denotes the TSW was not installed; Superscripts denote number of transitions used to calculate percentage: ${ }^{\mathrm{a}}$, greater than $100 ;^{\mathrm{b}}, 50-100 ;{ }^{\mathrm{c}}, 10$ to $50 ;\left({ }^{*}\right)$, less than 10 , which was insufficient sample size to calculate percentage]

\begin{tabular}{|c|c|c|c|c|c|c|c|}
\hline \multicolumn{8}{|c|}{ Area of Passage } \\
\hline \multirow[b]{2}{*}{ Species } & $\mathrm{PH} \# 1$ & $\mathrm{PH} \# 2$ & $\mathrm{PH} \# 3$ & \multicolumn{4}{|c|}{ Spillway } \\
\hline & & & & TSW 20 & $\underline{\text { TSW } 19}$ & Bays & TSW 4 \\
\hline $\mathrm{YCH}$ & $20^{\mathrm{a}}$ & $22^{\mathrm{a}}$ & $20^{\mathrm{a}}$ & $36^{\mathrm{a}}$ & $16^{\mathrm{a}}$ & $36^{\mathrm{a}}$ & 1 \\
\hline STH & $14^{\mathrm{a}}$ & $9^{\mathrm{a}}$ & $10^{\mathrm{a}}$ & $39^{\mathrm{a}}$ & $15^{\mathrm{a}}$ & $21^{\mathrm{a}}$ & 1 \\
\hline $\mathrm{SCH}$ & $23^{\mathrm{a}}$ & $16^{\mathrm{a}}$ & $15^{\mathrm{a}}$ & $20^{\mathrm{a}}$ & $16^{\mathrm{a}}$ & $51^{\mathrm{a}}$ & 1 \\
\hline SOC & $39^{c}$ & $83^{b}$ & $36^{\mathrm{c}}$ & $*$ & $*$ & $*$ & 1 \\
\hline
\end{tabular}

Of the fish that first approached the dam in the powerhouse area and transitioned into the spillway area, the proportion of steelhead that passed the dam remained high in $2008(0.75)$. This was an increase compared to 2006 (0.66), but a decrease from what was observed in $2007(0.89)$. The pattern was similar for subyearling Chinook salmon. Of the subyearling Chinook salmon that entered the spillway area, passage probabilities through all routes combined in the spillway area remained high in 2008 (0.87) compared to 2006 (0.92), and was about the same compared to 2007 (0.91). Passage probability in the spillway area was relatively high for yearling Chinook salmon in 2006 (0.95) and increased in 2007 (0.98), but decreased in 2008 (0.88). Detection probabilities in the spillway for sockeye salmon were too low to examine the effect of moving the location of the TSW in 2008 compared to 2007.

The decrease in passage probabilities in the southern portion of the spillway observed in 2008 also was observed in 2009, likely a result of having only one TSW in this area during the spring study period. As was the case in previous years, after first being detected in the powerhouse areas, greater than 0.69 of all species transitioned out of the powerhouse areas into adjoining areas (table 14). After fish entered the spillway area, passage probabilities were high in 2009 compared to 2006, but lower for some species compared to what was observed during the other 2 years (2007 and 2008) when TSWs were tested (table 15). During the 2009 spring study season, the addition of the TSW to the northern portion of the spillway area increased passage probabilities in that area for fish that were first detected in the powerhouse. 


\section{Table 14. Percentage of fish passing McNary Dam during day and night periods in 2009 based on a one-step Markov Chain analysis.}

[Data represent all fish that first approached the powerhouse and include both day and night periods. Species: YCH, Yearling Chinook salmon; STH, juvenile steelhead; SCH, subyearling Chinook salmon; SOC, Sockeye salmon. Area of Passage: PH\#1, turbine units 1-5; PH\#2, turbine units 6-10; PH\#3, turbine units 11-14; Spillway, spill bays 1-22; TSW, temporary spillway weir; $(\backslash)$ denotes the TSW was not installed; Superscripts denote number of transitions used to calculate percentage: ${ }^{\mathrm{a}}$, greater than $100 ;{ }^{\mathrm{b}}, 50-100 ;{ }^{\mathrm{c}}, 10$ to $50 ;\left(^{*}\right)$, less than 10, which was insufficient sample size to calculate percentage]

\begin{tabular}{|c|c|c|c|c|c|c|c|}
\hline \multicolumn{8}{|c|}{ Area of Passage } \\
\hline \multirow[b]{2}{*}{ Species } & PH \#1 & PH \#2 & $\mathrm{PH} \# 3$ & \multicolumn{4}{|c|}{ Spillway } \\
\hline & & & & TSW 20 & $\underline{\text { TSW } 19}$ & Bays & TSW 4 \\
\hline $\mathrm{YCH}$ & $20^{\mathrm{a}}$ & $17^{\mathrm{a}}$ & $27^{\mathrm{a}}$ & $23^{\mathrm{a}}$ & 1 & $64^{\mathrm{a}}$ & $4^{\mathrm{a}}$ \\
\hline STH & $10^{\mathrm{a}}$ & $9^{\mathrm{a}}$ & $7^{\mathrm{a}}$ & $37^{\mathrm{a}}$ & 1 & $33^{\mathrm{a}}$ & $8^{\mathrm{a}}$ \\
\hline $\mathrm{SCH}$ & $16^{\mathrm{a}}$ & $11^{\mathrm{a}}$ & $30^{\mathrm{a}}$ & $34^{\mathrm{a}}$ & $9^{\mathrm{a}}$ & $49^{\mathrm{a}}$ & 1 \\
\hline SOC & $30^{\mathrm{a}}$ & $31^{\mathrm{a}}$ & $26^{\mathrm{a}}$ & $31^{\mathrm{a}}$ & 1 & $64^{\mathrm{a}}$ & $1^{\mathrm{a}}$ \\
\hline
\end{tabular}

Table 15. Percentage of fish passing McNary Dam through all routes combined (TSW and standard bays) within the spillway area by species and study year during day and night periods based on a one-step Markov Chain analysis.

[Data represent all fish that first approached the powerhouse and include both day and night periods. Superscripts denote number of transitions used to calculate percentage: ${ }^{\mathrm{a}}$, greater than $100 ;^{\mathrm{b}}, 50-100 ;{ }^{\mathrm{c}}, 10$ to $50 ;\left(^{*}\right)$, less than 10 , which was insufficient sample size to calculate percentage; TSWs were not installed during 2006 and only one of the two TSWs was installed in the southern portion of the spillway area during the spring of 2009 when yearling Chinook salmon and steelhead passed the dam]

\begin{tabular}{lcccc}
\hline \multicolumn{5}{c}{ Passage through the spillway area by study year } \\
\hline \multirow{2}{*}{ Species } & 2006 & 2007 & 2008 & 2009 \\
\cline { 2 - 5 } Yearling Chinook Salmon & $95^{\mathrm{a}}$ & $98^{\mathrm{a}}$ & $88^{\mathrm{a}}$ & $91^{\mathrm{a}}$ \\
Steelhead & $66^{\mathrm{a}}$ & $89^{\mathrm{a}}$ & $75^{\mathrm{a}}$ & $78^{\mathrm{a}}$ \\
Subyearling Chinook Salmon & $92^{\mathrm{a}}$ & $91^{\mathrm{a}}$ & $87^{\mathrm{a}}$ & $92^{\mathrm{a}}$ \\
Sockeye & $100^{\mathrm{c}}$ & $85^{\mathrm{c}}$ & $*$ & $96^{\mathrm{a}}$ \\
\hline
\end{tabular}




\section{Transition Probabilities after First Approaching the Spillway}

During 2006, between 0.56 and 0.96 fish that first approached the spillway passed through the spillway; the remaining 0.44 to 0.04 transitioning to an adjoining area before passing (table 16). Compared to fish that were first detected in the powerhouse in 2006, we observed lower passage probabilities in the $\mathrm{PH \# 2}$ and $\mathrm{PH \# 3}$ powerhouse areas for all species that were first detected in the spillway. This indicated that a lower proportion of fish that were first detected in the spillway transitioned to the powerhouse before passing the dam compared to the proportion of fish that passed the dam through the powerhouse after first being detected in the powerhouse. This trend continued in 2007 for steelhead (table 17). After fish entered the spillway area, passage of yearling Chinook salmon through this area decreased in 2007 (0.88) compared to $2006(0.96)$. This was not the case for the other two species. Passage probabilities for steelhead first detected in the spillway increased in the spillway area from 0.63 in 2006 to 0.74 in 2007 and from 0.56 in 2006 to 0.82 in 2007 for subyearling Chinook salmon. Detection efficiencies for sockeye salmon in 2006 were too low to compare passage probabilities through the spillway area to what was observed in 2007 (0.49).

Moving the TSWs during 2008 impacted passage probabilities for fish that were first detected in the spillway. Of the fish that entered the spillway area, passage probabilities decreased from 0.88 in 2007 to 0.73 in 2008 for yearling Chinook salmon (table 18). The proportion of steelhead that passed through the spillway also decreased from 0.74 in 2007 to 0.58 in 2008 and much of the decrease was attributed to the relatively low passage probabilities through TSW 20 in $2008(0.16)$ compared to TSW 22 in 2007 (0.26). Passage probabilities through the spillway area decreased from 0.82 in 2007 to 0.73 in 2008 for subyearling Chinook salmon with much of the decrease attributed to passage through the TSWs. Once again, variable detection efficiencies for sockeye salmon across the study years hindered our ability to make annual comparisons for this species.

Passage probabilities in the southern spillway area during 2009 for fish that were first detected in the spillway were affected by having only one TSW as a passage alternative in this area. The overall passage through the spillway area increased for all species compared to 2008, but much of the increased passage occurred through the standard bays, not through the TSW in bay 20 (table 19). Across all years, with the exception of yearling Chinook salmon, the configuration that resulted in more fish passing the TSW in the southern spillway area after first being detected in the spillway was during 2007 (table 20). 


\section{Table 16. Percentage of fish passing McNary Dam during day and night periods in 2006 based on a one-step Markov Chain analysis.}

[Data represent all fish that first approached the spillway and include both day and night periods. Species: YCH, Yearling Chinook salmon; STH, juvenile steelhead; SCH, subyearling Chinook salmon; SOC, Sockeye salmon. Area of Passage: PH\#1, turbine units 1-5; PH\#2, turbine units 6-10; PH\#3, turbine units 11-14; Spillway, spill bays 1-22; TSW, temporary spillway weir; $(\backslash)$ denotes the TSW was not installed; Superscripts denote number of transitions used to calculate percentage: ${ }^{a}$, greater than $100 ;{ }^{b}, 50-100 ;{ }^{c}, 10$ to $50 ;(*)$, less than 10 , which was insufficient sample size to calculate percentage]

\begin{tabular}{|c|c|c|c|c|c|c|c|}
\hline \multicolumn{8}{|c|}{ Area of Passage } \\
\hline \multirow[b]{2}{*}{ Species } & PH \#1 & PH \#2 & $\mathrm{PH} \# 3$ & \multicolumn{4}{|c|}{ Spillway } \\
\hline & & & & TSW 22 & $\underline{\text { TSW } 20}$ & Bays & TSW 4 \\
\hline $\mathrm{YCH}$ & $*$ & $26^{\mathrm{c}}$ & $9^{c}$ & 1 & 1 & $96^{\mathrm{a}}$ & 1 \\
\hline STH & $17^{\mathrm{b}}$ & $6^{\mathrm{a}}$ & $7^{\mathrm{a}}$ & 1 & 1 & $63^{\mathrm{a}}$ & 1 \\
\hline $\mathrm{SCH}$ & $20^{\mathrm{b}}$ & $6^{\mathrm{b}}$ & $2^{\mathrm{b}}$ & 1 & 1 & $56^{\mathrm{b}}$ & 1 \\
\hline $\mathrm{SOC}$ & * & * & $*$ & 1 & 1 & $*$ & 1 \\
\hline
\end{tabular}

\section{Table 17. Percentage of fish passing McNary Dam during day and night periods in 2007 based on a} one-step Markov Chain analysis.

[Data represent all fish that first approached the spillway and include both day and night periods. Species: YCH, Yearling Chinook salmon; STH, juvenile steelhead; SCH, subyearling Chinook salmon; SOC, Sockeye salmon. Area of Passage: PH\#1, turbine units 1-5; PH\#2, turbine units 6-10; PH\#3, turbine units 11-14; Spillway, spill bays 1-22; TSW, temporary spillway weir; $(\backslash)$ denotes the TSW was not installed; Superscripts denote number of transitions used to calculate percentage: ${ }^{a}$, greater than $100 ;{ }^{b}, 50-100 ;{ }^{c}, 10$ to $50 ;(*)$, less than 10 , which was insufficient sample size to calculate percentage]

\begin{tabular}{|c|c|c|c|c|c|c|c|}
\hline \multicolumn{8}{|c|}{ Area of Passage } \\
\hline \multirow[b]{2}{*}{ Species } & \multirow[t]{2}{*}{ PH \#1 } & \multirow[t]{2}{*}{ PH \#2 } & \multirow[t]{2}{*}{$\mathrm{PH} \# 3$} & \multicolumn{4}{|c|}{ Spillway } \\
\hline & & & & TSW 22 & TSW 20 & $\underline{\text { Bays }}$ & TSW 4 \\
\hline YCH & $16^{\mathrm{c}}$ & $35^{\mathrm{c}}$ & $22^{\mathrm{b}}$ & $16^{\mathrm{a}}$ & $16^{\mathrm{a}}$ & $56^{\mathrm{a}}$ & 1 \\
\hline STH & $6^{\mathrm{a}}$ & $5^{\mathrm{a}}$ & $4^{\mathrm{a}}$ & $26^{\mathrm{a}}$ & $25^{\mathrm{a}}$ & $23^{\mathrm{a}}$ & 1 \\
\hline $\mathrm{SCH}$ & $21^{\mathrm{c}}$ & $11^{\mathrm{c}}$ & $16^{c}$ & $24^{\mathrm{a}}$ & $26^{\mathrm{a}}$ & $32^{\mathrm{a}}$ & 1 \\
\hline SOC & $*$ & $*$ & $62^{c}$ & $22^{c}$ & $19^{c}$ & $8^{c}$ & 1 \\
\hline
\end{tabular}




\section{Table 18. Percentage of fish passing McNary Dam during day and night periods in 2008 based on a one-step Markov Chain analysis.}

[Data represent all fish that first approached the spillway and include both day and night periods. Species: YCH, Yearling Chinook salmon; STH, juvenile steelhead; SCH, subyearling Chinook salmon; SOC, Sockeye salmon. Area of Passage: PH\#1, turbine units 1-5; PH\#2, turbine units 6-10; PH\#3, turbine units 11-14; Spillway, spill bays 1-22; TSW, temporary spillway weir; $(\backslash)$ denotes the TSW was not installed; Superscripts denote number of transitions used to calculate percentage: a, greater than 100; b , 50-100; c , 10 to 50; (*), less than 10, which was insufficient sample size to calculate percentage]

\begin{tabular}{|c|c|c|c|c|c|c|c|}
\hline \multicolumn{8}{|c|}{ Area of Passage } \\
\hline \multirow[b]{2}{*}{ Species } & PH \#1 & PH \#2 & $\mathrm{PH} \# 3$ & \multicolumn{4}{|c|}{ Spillway } \\
\hline & & & & TSW 20 & $\underline{\text { TSW } 19}$ & Bays & TSW 4 \\
\hline $\mathrm{YCH}$ & $12^{\mathrm{c}}$ & $14^{\mathrm{c}}$ & $36^{\mathrm{b}}$ & $14^{\mathrm{a}}$ & $28^{\mathrm{a}}$ & $31^{\mathrm{a}}$ & 1 \\
\hline STH & $8^{\mathrm{c}}$ & $1^{\mathrm{b}}$ & $9^{\mathrm{a}}$ & $16^{\mathrm{a}}$ & $20^{\mathrm{a}}$ & $22^{\mathrm{a}}$ & 1 \\
\hline $\mathrm{SCH}$ & $3^{c}$ & $3^{c}$ & $23^{\mathrm{c}}$ & $18^{\mathrm{a}}$ & $20^{\mathrm{a}}$ & $35^{\mathrm{a}}$ & 1 \\
\hline $\mathrm{SOC}$ & * & $*$ & 1 & * & * & $*$ & 1 \\
\hline
\end{tabular}

Table 19. Percentage of fish passing McNary Dam during day and night periods in 2009 based on a one-step Markov Chain analysis.

[Data represent all fish that first approached the spillway and include both day and night periods. Species: YCH, Yearling Chinook salmon; STH, juvenile steelhead; SCH, subyearling Chinook salmon; SOC, Sockeye salmon. Area of Passage: PH\#1, turbine units 1-5; PH\#2, turbine units 6-10; PH\#3, turbine units 11-14; Spillway, spill bays 1-22; TSW, temporary spillway weir; $(\backslash)$ denotes the TSW was not installed; Superscripts denote number of transitions used to calculate percentage: a, greater than 100; b , 50-100; c , 10 to 50; $\left(^{*}\right)$, less than 10, which was insufficient sample size to calculate percentage]

\begin{tabular}{cc|c|c|cccc}
\hline & & \multicolumn{9}{c}{ Area of Passage } \\
Species & PH \#1 & PH \#2 & PH \#3 & \multicolumn{4}{c}{ Spillway } \\
\cline { 2 - 8 } YCH & $32^{\mathrm{c}}$ & $27^{\mathrm{c}}$ & $36^{\mathrm{b}}$ & $\underline{\text { TSW 20 }}$ & $\underline{\text { TSW 19 }}$ & $\underline{\text { Bays }}$ & $\underline{\text { TSW 4 }}$ \\
STH & $8^{\mathrm{a}}$ & $7^{\mathrm{a}}$ & $15^{\mathrm{a}}$ & $20^{\mathrm{a}}$ & $\backslash$ & $64^{\mathrm{a}}$ & $8^{\mathrm{a}}$ \\
$\mathrm{SCH}$ & $4^{\mathrm{c}}$ & $11^{\mathrm{c}}$ & $31^{\mathrm{b}}$ & $11^{\mathrm{a}}$ & $21^{\mathrm{a}}$ & $51^{\mathrm{a}}$ & $13^{\mathrm{a}}$ \\
SOC & $*$ & $27^{\mathrm{c}}$ & $36^{\mathrm{b}}$ & $24^{\mathrm{a}}$ & $\backslash$ & $61^{\mathrm{a}}$ & $12^{\mathrm{a}}$ \\
\hline
\end{tabular}


Table 20. Percentage of fish passing McNary Dam through the TSWs in the southern portion of the spillway area by species and study year during day and night periods from 2006 to 2009 based on a one-step Markov Chain analysis.

[Data represent all fish that first approached the spillway and include both day and night periods. Superscripts denote number of transitions used to calculate percentage: a, greater than 100; b , 50-100; c , 10 to 50; (*), less than 10, which was insufficient sample size to calculate percentage; $(\backslash)$ denotes the TSW was not installed; only one of the two TSWs was installed in the southern spillway area during the spring of 2009 when yearling Chinook salmon and steelhead passed the dam.]

\begin{tabular}{|c|c|c|c|c|}
\hline \multicolumn{5}{|c|}{ Passage through the spillway area by study year } \\
\hline Species & 2006 & 2007 & 2008 & 2009 \\
\hline Yearling Chinook Salmon & 1 & $32^{\mathrm{a}}$ & $42^{\mathrm{a}}$ & $21^{\mathrm{a}}$ \\
\hline Steelhead & 1 & $51^{\mathrm{a}}$ & $36^{\mathrm{a}}$ & $33^{\mathrm{a}}$ \\
\hline Subyearling Chinook Salmon & 1 & $50^{\mathrm{a}}$ & $38^{\mathrm{a}}$ & $32^{\mathrm{a}}$ \\
\hline Sockeye & 1 & $41^{\mathrm{c}}$ & $*$ & $36^{\mathrm{a}}$ \\
\hline
\end{tabular}

\section{Transition Probabilities during Day and Night for Fish that First Approached the Powerhouse}

Passage probabilities during the day and night periods varied among species and study years. The results for fish that first approached the powerhouse during the day and night are presented first, followed by the results for fish that first approached the spillway and passed the dam during the day and night.

In 2006, daytime passage for steelhead and subyearling Chinook salmon was higher than nighttime passage in the spillway for fish that first approached the powerhouse (tables 21 and 22).

Passage probabilities for yearling Chinook salmon were nearly the same for day and night. Results were mixed in the powerhouse areas. Passage probabilities were higher at night for yearling Chinook salmon, higher during the day for subyearling Chinook salmon and sockeye salmon (except in PH\#1 area), and about the same during the day and night for steelhead.

During 2007, a higher proportion of steelhead passed through the spillway area during the day compared to the night, primarily through the two TSWs in bays 20 and 22 (0.88) (tables 23 and 24). The passage probability for steelhead through all passage routes in the spillway area was 0.81 during the night and 0.91 during the day. Passage probability for subyearling Chinook salmon was about the same during the night (0.91) and day (0.90). Similarly, passage probabilities for yearling Chinook salmon remained about the same during the night (0.99) and day (0.98). Sockeye salmon had higher passage probabilities during the night (0.87) compared to the day (0.80), but sample size was low. If only fish that passed through the two TSW were considered, passage probabilities were higher during the day compared to night for all species except sockeye salmon. The probability of passing the powerhouse in 2007 during the day or night was variable among the species and no clear pattern could be identified among the four species. 


\section{Table 21. Percentage of fish passing McNary Dam during day period in 2006 based on a one-step Markov Chain analysis.}

Data represent all fish that first approached the powerhouse during the day period. [Species: YCH, Yearling Chinook salmon; STH, juvenile steelhead; SCH, subyearling Chinook salmon; SOC, Sockeye salmon. Area of Passage: PH\#1, turbine units 1-5; PH\#2, turbine units 6-10; PH\#3, turbine units 11-14; Spillway, spill bays 122; TSW, temporary spillway weir; $(\backslash)$ denotes the TSW was not installed; Superscripts denote number of transitions used to calculate percentage: ${ }^{a}$, greater than $100 ;{ }^{b}, 50-100 ;{ }^{c}, 10$ to $50 ;(*)$, less than 10 , which was insufficient sample size to calculate percentage]

\begin{tabular}{cc|c|c|cccc}
\hline & & \multicolumn{9}{c}{ Area of Passage } \\
Species & PH \#1 & PH \#2 & PH \#3 & \multicolumn{4}{c}{ Spillway } \\
\cline { 2 - 7 } YCH & $14^{\mathrm{a}}$ & $20^{\mathrm{a}}$ & $24^{\mathrm{a}}$ & $\underline{\text { TSW 22 }}$ & $\underline{\text { TSW 20 }}$ & $\underline{\text { Bays }}$ & $\underline{\text { TSW 4 }}$ \\
STH & $10^{\mathrm{a}}$ & $9^{\mathrm{a}}$ & $7^{\mathrm{a}}$ & $\backslash$ & $\backslash$ & $95^{\mathrm{b}}$ & $\backslash$ \\
$\mathrm{SCH}$ & $25^{\mathrm{a}}$ & $22^{\mathrm{a}}$ & $20^{\mathrm{a}}$ & $\backslash$ & $\backslash$ & $98^{\mathrm{b}}$ & $\backslash$ \\
SOC & $23^{\mathrm{b}}$ & $54^{\mathrm{a}}$ & $56^{\mathrm{b}}$ & $\backslash$ & $\backslash$ & $*$ & $\backslash$ \\
\hline
\end{tabular}

\section{Table 22. Percentage of fish passing McNary Dam during night period in 2006 based on a one-step} Markov Chain analysis.

[Data represent all fish that first approached the powerhouse during the night period. Species: YCH, Yearling Chinook salmon; STH, juvenile steelhead; SCH, subyearling Chinook salmon; SOC, Sockeye salmon. Area of Passage: PH\#1, turbine units 1-5; PH\#2, turbine units 6-10; PH\#3, turbine units 11-14; Spillway, spill bays 122; TSW, temporary spillway weir; $(\backslash)$ denotes the TSW was not installed; Superscripts denote number of transitions used to calculate percentage: a, greater than 100 ; b , 50-100; c , 10 to 50; (*), less than 10, which was insufficient sample size to calculate percentage]

\begin{tabular}{cc|c|c|cccc}
\hline & & \multicolumn{9}{c}{ Area of Passage } \\
Species & PH \#1 & PH \#2 & PH \#3 & \multicolumn{4}{c}{ Spillway } \\
\cline { 2 - 7 } YCH & $33^{\mathrm{a}}$ & $31^{\mathrm{a}}$ & $36^{\mathrm{a}}$ & $\underline{\text { TSW 22 }}$ & $\underline{\text { TSW 20 }}$ & $\underline{\text { Bays }}$ & $\underline{\text { TSW 4 }}$ \\
STH & $15^{\mathrm{a}}$ & $6^{\mathrm{a}}$ & $6^{\mathrm{a}}$ & $\backslash$ & $\backslash$ & $66^{\mathrm{c}}$ & $\backslash$ \\
$\mathrm{SCH}$ & $16^{\mathrm{a}}$ & $14^{\mathrm{a}}$ & $8^{\mathrm{a}}$ & $\backslash$ & $\backslash$ & $89^{\mathrm{b}}$ & $\backslash$ \\
SOC & $36^{\mathrm{c}}$ & $31^{\mathrm{b}}$ & $35^{\mathrm{c}}$ & $\backslash$ & $\backslash$ & $*$ & $\backslash$ \\
\hline
\end{tabular}




\section{Table 23. Percentage of fish passing McNary Dam during day period in 2007 based on a one-step Markov Chain analysis.}

[Data represent all fish that first approached the powerhouse during the day period. Species: YCH, Yearling Chinook salmon; STH, juvenile steelhead; SCH, subyearling Chinook salmon; SOC, Sockeye salmon. Area of Passage: PH\#1, turbine units 1-5; PH\#2, turbine units 6-10; PH\#3, turbine units 11-14; Spillway, spill bays 122; TSW, temporary spillway weir; $(\backslash)$ denotes the TSW was not installed; Superscripts denote number of transitions used to calculate percentage: a, greater than 100; b , 50-100; c , 10 to 50; (*), less than 10, which was insufficient sample size to calculate percentage]

\begin{tabular}{cc|c|c|cccc}
\hline & & \multicolumn{9}{c}{ Area of Passage } \\
Species & PH \#1 & PH \#2 & PH \#3 & \multicolumn{4}{c}{ Spillway } \\
\cline { 2 - 7 } & & & & $\underline{\text { TSW 22 }}$ & $\underline{\text { TSW 20 }}$ & $\underline{\text { Bays }}$ & $\underline{\text { TSW 4 }}$ \\
YCH & $21^{\mathrm{a}}$ & $28^{\mathrm{a}}$ & $19^{\mathrm{a}}$ & $78^{\mathrm{a}}$ & $9^{\mathrm{a}}$ & $11^{\mathrm{a}}$ & $\backslash$ \\
$\mathrm{STH}$ & $3^{\mathrm{a}}$ & $2^{\mathrm{a}}$ & $2^{\mathrm{a}}$ & $77^{\mathrm{a}}$ & $11^{\mathrm{a}}$ & $3^{\mathrm{a}}$ & $\backslash$ \\
$\mathrm{SCH}$ & $29^{\mathrm{a}}$ & $27^{\mathrm{a}}$ & $16^{\mathrm{a}}$ & $63^{\mathrm{a}}$ & $12^{\mathrm{a}}$ & $15^{\mathrm{a}}$ & $\backslash$ \\
SOC & $34^{\mathrm{a}}$ & $39^{\mathrm{a}}$ & $20^{\mathrm{b}}$ & $50^{\mathrm{c}}$ & $10^{\mathrm{c}}$ & $20^{\mathrm{c}}$ & $\backslash$ \\
\hline
\end{tabular}

Table 24. Percentage of fish passing McNary Dam during night period in 2007 based on a one-step Markov Chain analysis.

[Data represent all fish that first approached the powerhouse during the night period. Species: YCH, Yearling Chinook salmon; STH, juvenile steelhead; SCH, subyearling Chinook salmon; SOC, Sockeye salmon. Area of Passage: PH\#1, turbine units 1-5; PH\#2, turbine units 6-10; PH\#3, turbine units 11-14; Spillway, spill bays 122; TSW, temporary spillway weir; $(\backslash)$ denotes the TSW was not installed; Superscripts denote number of transitions used to calculate percentage: a, greater than 100 ; b , 50-100; c , 10 to 50; (*), less than 10, which was insufficient sample size to calculate percentage]

\begin{tabular}{|c|c|c|c|c|c|c|c|}
\hline \multicolumn{8}{|c|}{ Area of Passage } \\
\hline \multirow[b]{2}{*}{ Species } & PH \#1 & $\mathrm{PH} \# 2$ & $\mathrm{PH} \# 3$ & \multicolumn{4}{|c|}{ Spillway } \\
\hline & & & & TSW 22 & TSW 20 & $\underline{\text { Bays }}$ & TSW 4 \\
\hline YCH & $25^{\mathrm{a}}$ & $26^{\mathrm{a}}$ & $17^{\mathrm{a}}$ & $78^{\mathrm{b}}$ & $5^{\mathrm{b}}$ & $16^{\mathrm{b}}$ & 1 \\
\hline STH & $9^{a}$ & $6^{\mathrm{a}}$ & $7^{\mathrm{a}}$ & $49^{\mathrm{a}}$ & $16^{\mathrm{a}}$ & $16^{\mathrm{a}}$ & 1 \\
\hline $\mathrm{SCH}$ & $15^{\mathrm{a}}$ & $15^{\mathrm{a}}$ & $10^{\mathrm{a}}$ & $48^{\mathrm{b}}$ & $16^{\mathrm{b}}$ & $27^{\mathrm{b}}$ & 1 \\
\hline SOC & $39^{\mathrm{a}}$ & $39^{\mathrm{a}}$ & $18^{\mathrm{b}}$ & $56^{\mathrm{c}}$ & $25^{\mathrm{c}}$ & $6^{\mathrm{c}}$ & 1 \\
\hline
\end{tabular}


After fish entered the spillway area in 2008, passage probabilities for all routes combined in this area were consistently higher during the day compared to the night for yearling Chinook salmon, steelhead, and subyearling Chinook salmon (tables 25 and 26). Passage probabilities during the day for all routes in the spillway area combined increased by 0.18 for yearling Chinook salmon ( 0.95 day, 0.77 night), by 0.14 for steelhead ( 0.82 day, 0.68 night), and by 0.11 for subyearling Chinook salmon (0.91 day, 0.80 night). Low detection efficiency for sockeye salmon in the spillway during 2008 prevented us from examining differences in day and night passage probabilities. If only fish that passed through the two TSWs combined are considered, daytime passage remained higher than nighttime passage for steelhead, remained about the same for yearling Chinook salmon, and was higher during the night for subyearling Chinook salmon compared to day. Passage through the powerhouse routes remained about the same during the day and night for yearling Chinook salmon and subyearling Chinook salmon but was noticeably higher during the night for steelhead. Similar patterns in passage probabilities were observed during 2009. Passage probabilities within the spillway area remained higher during the day compared to night for yearling Chinook salmon and steelhead and were about the same for subyearling Chinook salmon (tables 27 and 28).

\section{Transition Probabilities during Day and Night for Fish that First Approached the Spillway.}

There were no consistent patterns between day and night passage probabilities for fish that first approached the spillway. In 2006, passage proportions in the spillway for yearling Chinook salmon and subyearling Chinook salmon were higher during night compared to day and the opposite was observed for steelhead (tables 29 and 30). The relatively low number of transitions used to calculate the passage probabilities in 2006 for subyearling Chinook salmon in the spillway area could have contributed to these inconsistent results. Similarly, low detection probabilities for sockeye salmon in the spillway during 2006 preclude day and night comparisons.

In 2007, sample sizes were higher, and the results were more consistent, perhaps because of the installation of the TSWs. With the exception of sockeye salmon, of the fish that entered the spillway area, a higher proportion of fish passed this area during the day compared to night, especially for steelhead (tables 31 and 32). This same pattern was observed during 2008 and 2009 (tables 33, 34, 35, and 36).

For the fish that first approached the spillway, the proportion that subsequently passed the powerhouse areas during the day versus the night did not reveal consistent trends. The relatively low number of transitions (10-50) used to generate the passage probabilities in the powerhouse areas likely contributed to the variability in the results.

\section{Two-Step Markov Chain Results}

The results from the two-step analysis are presented in the following sections. The main difference between the one-step and two-step analysis is where the fish was located before it transitioned and passed the dam. For example, table 37 shows the passage probabilities of fish passing McNary Dam during 2006 based on a two-step analysis. In this example, 0.92 of the subyearling Chinook salmon that entered the spillway area passed through the spillway area after first transitioning from the PH\#3 area. Only 0.46 of the subyearling Chinook salmon that entered the spillway area passed through that area after first transitioning from the forebay. The two-step analysis allowed us to investigate how passage probabilities were influenced by where the fish was located before it transitioned into and passed one of the four areas upstream of the dam. 


\section{Table 25. Percentage of fish passing McNary Dam during day period in 2008 based on a one-step Markov Chain analysis.}

[Data represent all fish that first approached the powerhouse during the day period. Species: YCH, Yearling Chinook salmon; STH, juvenile steelhead; SCH, subyearling Chinook salmon; SOC, Sockeye salmon. Area of Passage: PH\#1, turbine units 1-5; PH\#2, turbine units 6-10; PH\#3, turbine units 11-14; Spillway, spill bays 122; TSW, temporary spillway weir; $(\backslash)$ denotes the TSW was not installed; Superscripts denote number of transitions used to calculate percentage: a, greater than 100 ; b , 50-100; c , 10 to 50; (*), less than 10, which was insufficient sample size to calculate percentage]

\begin{tabular}{cc|c|c|cccc}
\hline & & \multicolumn{9}{c}{ Area of Passage } \\
& PH \#1 & PH \#2 & PH \#3 & \multicolumn{4}{c}{ Spillway } \\
\cline { 2 - 7 } & & & & $\underline{\text { TSW 20 }}$ & $\underline{\text { TSW 19 }}$ & $\underline{\text { Bays }}$ & $\underline{\text { TSW 4 }}$ \\
YCH & $17^{\mathrm{a}}$ & $25^{\mathrm{a}}$ & $21^{\mathrm{a}}$ & $36^{\mathrm{b}}$ & $16^{\mathrm{b}}$ & $43^{\mathrm{b}}$ & $\backslash$ \\
$\mathrm{STH}$ & $8^{\mathrm{a}}$ & $4^{\mathrm{a}}$ & $8^{\mathrm{a}}$ & $46^{\mathrm{a}}$ & $19^{\mathrm{a}}$ & $17^{\mathrm{a}}$ & $\backslash$ \\
$\mathrm{SCH}$ & $22^{\mathrm{a}}$ & $19^{\mathrm{a}}$ & $15^{\mathrm{a}}$ & $19^{\mathrm{a}}$ & $14^{\mathrm{a}}$ & $58^{\mathrm{a}}$ & $\backslash$ \\
$\mathrm{SOC}$ & $36^{\mathrm{c}}$ & $82^{\mathrm{b}}$ & $36^{\mathrm{c}}$ & $*$ & $*$ & $*$ & $\backslash$ \\
\hline
\end{tabular}

\section{Table 26. Percentage of fish passing McNary Dam during night period in 2008 based on a one-step} Markov Chain analysis.

[Data represent all fish that first approached the powerhouse during the night period. Species: YCH, Yearling Chinook salmon; STH, juvenile steelhead; SCH, subyearling Chinook salmon; SOC, Sockeye salmon. Area of Passage: PH\#1, turbine units 1-5; PH\#2, turbine units 6-10; PH\#3, turbine units 11-14; Spillway, spill bays 122; TSW, temporary spillway weir; $(\backslash)$ denotes the TSW was not installed; Superscripts denote number of transitions used to calculate percentage: a, greater than 100 ; b , 50-100; c , 10 to 50; (*), less than 10, which was insufficient sample size to calculate percentage]

\begin{tabular}{|c|c|c|c|c|c|c|c|}
\hline \multicolumn{8}{|c|}{ Area of Passage } \\
\hline \multirow[b]{2}{*}{$\underline{\text { Species }}$} & PH \#1 & $\mathrm{PH} \# 2$ & $\mathrm{PH} \# 3$ & \multicolumn{4}{|c|}{ Spillway } \\
\hline & & & & TSW 20 & TSW 19 & Bays & TSW 4 \\
\hline $\mathrm{YCH}$ & $26^{\mathrm{b}}$ & $17^{\mathrm{a}}$ & $18^{\mathrm{b}}$ & $35^{\mathrm{c}}$ & $16^{\mathrm{c}}$ & $26^{\mathrm{c}}$ & 1 \\
\hline STH & $17^{\mathrm{a}}$ & $11^{\mathrm{a}}$ & $12^{\mathrm{a}}$ & $31^{\mathrm{a}}$ & $10^{\mathrm{a}}$ & $27^{\mathrm{a}}$ & 1 \\
\hline $\mathrm{SCH}$ & $24^{\mathrm{a}}$ & $12^{\mathrm{a}}$ & $14^{\mathrm{b}}$ & $26^{\mathrm{c}}$ & $21^{\mathrm{c}}$ & $33^{\mathrm{c}}$ & 1 \\
\hline $\mathrm{SOC}$ & $*$ & $90^{\mathrm{c}}$ & * & * & $*$ & $*$ & 1 \\
\hline
\end{tabular}




\section{Table 27. Percentage of fish passing McNary Dam during day period in 2009 based on a one-step Markov Chain analysis.}

[Data represent all fish that first approached the powerhouse during the day period. Species: YCH, Yearling Chinook salmon; STH, juvenile steelhead; SCH, subyearling Chinook salmon; SOC, Sockeye salmon. Area of Passage: PH\#1, turbine units 1-5; PH\#2, turbine units 6-10; PH\#3, turbine units 11-14; Spillway, spill bays 122; TSW, temporary spillway weir; $(\backslash)$ denotes the TSW was not installed; Superscripts denote number of transitions used to calculate percentage: a, greater than 100 ; b , 50-100; c , 10 to 50; (*), less than 10, which was insufficient sample size to calculate percentage]

\begin{tabular}{cc|c|c|cccc}
\hline & & \multicolumn{9}{c}{ Area of Passage } \\
Species & PH \#1 & PH \#2 & PH \#3 & \multicolumn{4}{c}{ Spillway } \\
\cline { 2 - 7 } & & & & $\underline{T S W} 20$ & $\underline{T S W} 19$ & $\underline{\text { Bays }}$ & $\underline{\text { TSW 4 }}$ \\
YCH & $21^{\mathrm{a}}$ & $16^{\mathrm{a}}$ & $29^{\mathrm{a}}$ & $20^{\mathrm{a}}$ & $\backslash$ & $69^{\mathrm{a}}$ & $4^{\mathrm{a}}$ \\
$\mathrm{STH}$ & $7^{\mathrm{a}}$ & $7^{\mathrm{a}}$ & $5^{\mathrm{a}}$ & $49^{\mathrm{a}}$ & $\backslash$ & $27^{\mathrm{a}}$ & $7^{\mathrm{a}}$ \\
$\mathrm{SCH}$ & $18^{\mathrm{a}}$ & $11^{\mathrm{a}}$ & $28^{\mathrm{a}}$ & $33^{\mathrm{a}}$ & $6^{\mathrm{a}}$ & $54^{\mathrm{a}}$ & $\backslash$ \\
SOC & $26^{\mathrm{a}}$ & $31^{\mathrm{a}}$ & $25^{\mathrm{a}}$ & $30^{\mathrm{a}}$ & $\backslash$ & $66^{\mathrm{a}}$ & $1^{\mathrm{a}}$ \\
\hline
\end{tabular}

Table 28. Percentage of fish passing McNary Dam during night period in 2009 based on a one-step Markov Chain analysis.

[Data represent all fish that first approached the powerhouse during the night period. Species: YCH, Yearling Chinook salmon; STH, juvenile steelhead; SCH, subyearling Chinook salmon; SOC, Sockeye salmon. Area of Passage: PH\#1, turbine units 1-5; PH\#2, turbine units 6-10; PH\#3, turbine units 11-14; Spillway, spill bays 122; TSW, temporary spillway weir; $(\backslash)$ denotes the TSW was not installed; Superscripts denote number of transitions used to calculate percentage: a, greater than 100; b , 50-100; c , 10 to 50; (*), less than 10, which was insufficient sample size to calculate percentage]

\begin{tabular}{cc|c|c|cccc}
\hline & & \multicolumn{9}{c}{ Area of Passage } \\
Species & PH \#1 & PH \#2 & PH \#3 & \multicolumn{4}{c}{ Spillway } \\
\cline { 2 - 7 } & & & & $\underline{\text { TSW 20 }}$ & $\underline{\text { TSW 19 }}$ & $\underline{\text { Bays }}$ & $\underline{\text { TSW 4 }}$ \\
YCH & $18^{\mathrm{a}}$ & $18^{\mathrm{a}}$ & $25^{\mathrm{a}}$ & $26^{\mathrm{b}}$ & $\backslash$ & $57^{\mathrm{b}}$ & $3^{\mathrm{b}}$ \\
$\mathrm{STH}$ & $12^{\mathrm{a}}$ & $10^{\mathrm{a}}$ & $9^{\mathrm{a}}$ & $26^{\mathrm{a}}$ & $\backslash$ & $39^{\mathrm{a}}$ & $9^{\mathrm{a}}$ \\
$\mathrm{SCH}$ & $15^{\mathrm{a}}$ & $12^{\mathrm{a}}$ & $31^{\mathrm{a}}$ & $34^{\mathrm{a}}$ & $13^{\mathrm{a}}$ & $43^{\mathrm{a}}$ & $\backslash$ \\
SOC & $35^{\mathrm{a}}$ & $33^{\mathrm{a}}$ & $26^{\mathrm{a}}$ & $31^{\mathrm{a}}$ & 1 & $60^{\mathrm{a}}$ & $2^{\mathrm{a}}$ \\
\hline
\end{tabular}




\section{Table 29. Percentage of fish passing McNary Dam during day period in 2006 based on a one-step Markov Chain analysis.}

[Data represent all fish that first approached the spillway during the day period. Species: YCH, Yearling Chinook salmon; STH, juvenile steelhead; SCH, subyearling Chinook salmon; SOC, Sockeye salmon. Area of Passage: PH\#1, turbine units 1-5; PH\#2, turbine units 6-10; PH\#3, turbine units 11-14; Spillway, spill bays 122; TSW, temporary spillway weir; $(\backslash)$ denotes the TSW was not installed; Superscripts denote number of transitions used to calculate percentage: a, greater than 100; b , 50-100; c , 10 to 50; (*), less than 10, which was insufficient sample size to calculate percentage]

\begin{tabular}{|c|c|c|c|c|c|c|c|}
\hline \multicolumn{8}{|c|}{ Area of Passage } \\
\hline \multirow[b]{2}{*}{ Species } & PH \#1 & $\mathrm{PH} \# 2$ & $\mathrm{PH} \# 3$ & \multicolumn{4}{|c|}{ Spillway } \\
\hline & & & & $\underline{\text { TSW } 22}$ & $\underline{\text { TSW } 20}$ & Bays & TSW 4 \\
\hline YCH & * & $31^{\mathrm{c}}$ & $11^{\mathrm{c}}$ & 1 & 1 & $94^{\mathrm{a}}$ & 1 \\
\hline STH & $14^{\mathrm{c}}$ & $6^{c}$ & $3^{c}$ & 1 & 1 & $70^{\mathrm{b}}$ & 1 \\
\hline $\mathrm{SCH}$ & $16^{\mathrm{c}}$ & $6^{\mathrm{b}}$ & $4^{\mathrm{b}}$ & 1 & 1 & $54^{\mathrm{b}}$ & 1 \\
\hline $\mathrm{SOC}$ & $*$ & $*$ & $*$ & 1 & 1 & $*$ & 1 \\
\hline
\end{tabular}

\section{Table 30. Percentage of fish passing McNary Dam during night period in 2006 based on a one-step} Markov Chain analysis.

[Data represent all fish that first approached the spillway during the night period. Species: YCH, Yearling Chinook salmon; STH, juvenile steelhead; SCH, subyearling Chinook salmon; SOC, Sockeye salmon. Area of Passage: PH\#1, turbine units 1-5; PH\#2, turbine units 6-10; PH\#3, turbine units 11-14; Spillway, spill bays 122; TSW, temporary spillway weir; $(\backslash)$ denotes the TSW was not installed; Superscripts denote number of transitions used to calculate percentage: a, greater than 100 ; b , 50-100; c , 10 to 50; (*), less than 10, which was insufficient sample size to calculate percentage]

\begin{tabular}{cc|c|c|cccc}
\hline & & \multicolumn{9}{c}{ Area of Passage } \\
Species & PH \#1 & PH \#2 & PH \#3 & \multicolumn{4}{c}{ Spillway } \\
\cline { 2 - 7 } YCH & $*$ & $*$ & $*$ & $\underline{\text { TSW 22 }}$ & $\underline{\text { TSW 20 }}$ & $\underline{\text { Bays }}$ & $\underline{\text { TSW 4 }}$ \\
STH & $18^{\mathrm{c}}$ & $5^{\mathrm{b}}$ & $8^{\mathrm{b}}$ & $\backslash$ & $\backslash$ & $58^{\mathrm{a}}$ & $\backslash$ \\
$\mathrm{SCH}$ & $24^{\mathrm{c}}$ & $6^{\mathrm{c}}$ & $0^{\mathrm{c}}$ & $\backslash$ & $\backslash$ & $59^{\mathrm{c}}$ & $\backslash$ \\
$\mathrm{SOC}$ & $*$ & $*$ & $*$ & $\backslash$ & $\backslash$ & $*$ & $\backslash$ \\
\hline
\end{tabular}




\section{Table 31. Percentage of fish passing McNary Dam during day period in 2007 based on a one-step Markov Chain analysis.}

[Data represent all fish that first approached the spillway during the day period. Species: YCH, Yearling Chinook salmon; STH, juvenile steelhead; SCH, subyearling Chinook salmon; SOC, Sockeye salmon. Area of Passage: PH\#1, turbine units 1-5; PH\#2, turbine units 6-10; PH\#3, turbine units 11-14; Spillway, spill bays 122; TSW, temporary spillway weir; $(\backslash)$ denotes the TSW was not installed; Superscripts denote number of transitions used to calculate percentage: a, greater than 100; b , 50-100; c , 10 to 50; (*), less than 10, which was insufficient sample size to calculate percentage]

\begin{tabular}{|c|c|c|c|c|c|c|c|}
\hline \multicolumn{8}{|c|}{ Area of Passage } \\
\hline \multirow[b]{2}{*}{ Species } & $\mathrm{PH} \# 1$ & $\mathrm{PH} \# 2$ & $\mathrm{PH} \# 3$ & \multicolumn{4}{|c|}{ Spillway } \\
\hline & & & & TSW 22 & $\underline{\text { TSW } 20}$ & Bays & TSW 4 \\
\hline $\mathrm{YCH}$ & $10^{\mathrm{c}}$ & $38^{\mathrm{c}}$ & $19^{c}$ & $14^{\mathrm{a}}$ & $16^{\mathrm{a}}$ & $59^{\mathrm{a}}$ & 1 \\
\hline STH & $10^{\mathrm{b}}$ & $1^{\mathrm{b}}$ & $2^{\mathrm{a}}$ & $26^{\mathrm{a}}$ & $30^{\mathrm{a}}$ & $22^{\mathrm{a}}$ & 1 \\
\hline $\mathrm{SCH}$ & $36^{\mathrm{c}}$ & $21^{\mathrm{c}}$ & $17^{\mathrm{c}}$ & $19^{\mathrm{b}}$ & $26^{\mathrm{b}}$ & $37^{\mathrm{b}}$ & 1 \\
\hline SOC & $*$ & $*$ & $50^{\mathrm{c}}$ & $15^{\mathrm{c}}$ & $20^{\mathrm{c}}$ & $5^{\mathrm{c}}$ & 1 \\
\hline
\end{tabular}

Table 32. Percentage of fish passing McNary Dam during night period in 2007 based on a one-step Markov Chain analysis.

[Data represent all fish that first approached the spillway during the night period. Species: YCH, Yearling Chinook salmon; STH, juvenile steelhead; SCH, subyearling Chinook salmon; SOC, Sockeye salmon. Area of Passage: PH\#1, turbine units 1-5; PH\#2, turbine units 6-10; PH\#3, turbine units 11-14; Spillway, spill bays 122; TSW, temporary spillway weir; ( $\backslash$ denotes the TSW was not installed; Superscripts denote number of transitions used to calculate percentage: a, greater than 100 ; b , 50-100; c , 10 to 50; (*), less than 10, which was insufficient sample size to calculate percentage]

\begin{tabular}{|c|c|c|c|c|c|c|c|}
\hline \multicolumn{8}{|c|}{ Area of Passage } \\
\hline \multirow[b]{2}{*}{ Species } & $\mathrm{PH} \# 1$ & $\mathrm{PH} \# 2$ & $\mathrm{PH} \# 3$ & \multicolumn{4}{|c|}{ Spillway } \\
\hline & & & & TSW 22 & TSW 20 & Bays & TSW 4 \\
\hline $\mathrm{YCH}$ & $*$ & $28^{\mathrm{c}}$ & $26^{c}$ & $20^{\mathrm{a}}$ & $16^{\mathrm{a}}$ & $48^{\mathrm{a}}$ & 1 \\
\hline STH & $5^{\mathrm{b}}$ & $9^{\mathrm{a}}$ & $5^{\mathrm{b}}$ & $25^{\mathrm{a}}$ & $13^{\mathrm{a}}$ & $27^{\mathrm{a}}$ & 1 \\
\hline $\mathrm{SCH}$ & $11^{\mathrm{c}}$ & $4^{c}$ & $14^{\mathrm{c}}$ & $30^{\mathrm{b}}$ & $25^{\mathrm{b}}$ & $26^{\mathrm{b}}$ & 1 \\
\hline SOC & $*$ & $*$ & $*$ & $29^{c}$ & $18^{\mathrm{c}}$ & $12^{\mathrm{c}}$ & 1 \\
\hline
\end{tabular}




\section{Table 33. Percentage of fish passing McNary Dam during day period in 2008 based on a one-step Markov Chain analysis.}

[Data represent all fish that first approached the spillway during the day period. Species: YCH, Yearling Chinook salmon; STH, juvenile steelhead; SCH, subyearling Chinook salmon; SOC, Sockeye salmon. Area of Passage: PH\#1, turbine units 1-5; PH\#2, turbine units 6-10; PH\#3, turbine units 11-14; Spillway, spill bays 122; TSW, temporary spillway weir; $(\backslash)$ denotes the TSW was not installed; Superscripts denote number of transitions used to calculate percentage: a, greater than 100; b , 50-100; c , 10 to 50; (*), less than 10, which was insufficient sample size to calculate percentage]

\begin{tabular}{|c|c|c|c|c|c|c|c|}
\hline \multicolumn{8}{|c|}{ Area of Passage } \\
\hline \multirow[b]{2}{*}{ Species } & PH \#1 & PH \#2 & $\mathrm{PH} \# 3$ & \multicolumn{4}{|c|}{ Spillway } \\
\hline & & & & TSW 20 & $\underline{\text { TSW } 19}$ & Bays & TSW 4 \\
\hline $\mathrm{YCH}$ & $0^{\mathrm{c}}$ & $11^{\mathrm{c}}$ & $29^{c}$ & $15^{\mathrm{b}}$ & $28^{\mathrm{b}}$ & $31^{\mathrm{b}}$ & 1 \\
\hline STH & $3^{c}$ & $0^{\mathrm{c}}$ & $5^{\mathrm{b}}$ & $20^{\mathrm{a}}$ & $23^{\mathrm{a}}$ & $20^{\mathrm{a}}$ & 1 \\
\hline $\mathrm{SCH}$ & $4^{c}$ & $0^{\mathrm{c}}$ & $23^{\mathrm{c}}$ & $19^{\mathrm{b}}$ & $17^{\mathrm{b}}$ & $37^{\mathrm{b}}$ & 1 \\
\hline $\mathrm{SOC}$ & * & * & $*$ & $*$ & $*$ & $*$ & 1 \\
\hline
\end{tabular}

Table 34. Percentage of fish passing McNary Dam during night period in 2008 based on a one-step Markov Chain analysis.

[Data represent all fish that first approached the spillway during the night period. Species: YCH, Yearling Chinook salmon; STH, juvenile steelhead; SCH, subyearling Chinook salmon; SOC, Sockeye salmon. Area of Passage: PH\#1, turbine units 1-5; PH\#2, turbine units 6-10; PH\#3, turbine units 11-14; Spillway, spill bays 122; TSW, temporary spillway weir; ( $\backslash$ denotes the TSW was not installed; Superscripts denote number of transitions used to calculate percentage: a, greater than 100 ; b , 50-100; c , 10 to 50; (*), less than 10, which was insufficient sample size to calculate percentage]

\begin{tabular}{|c|c|c|c|c|c|c|c|}
\hline \multicolumn{8}{|c|}{ Area of Passage } \\
\hline \multirow[b]{2}{*}{$\underline{\text { Species }}$} & \multirow[t]{2}{*}{ PH \#1 } & \multirow[t]{2}{*}{$\mathrm{PH} \# 2$} & \multirow[t]{2}{*}{$\mathrm{PH} \# 3$} & \multicolumn{4}{|c|}{ Spillway } \\
\hline & & & & TSW 20 & TSW 19 & Bays & TSW 4 \\
\hline $\mathrm{YCH}$ & $*$ & $*$ & $51^{\mathrm{c}}$ & $11^{\mathrm{c}}$ & $28^{\mathrm{c}}$ & $30^{c}$ & 1 \\
\hline STH & $17^{\mathrm{c}}$ & $3^{c}$ & $16^{\mathrm{b}}$ & $11^{\mathrm{b}}$ & $16^{\mathrm{b}}$ & $26^{\mathrm{b}}$ & 1 \\
\hline $\mathrm{SCH}$ & $0^{\mathrm{c}}$ & $8^{c}$ & $24^{\mathrm{c}}$ & $16^{\mathrm{c}}$ & $27^{\mathrm{c}}$ & $31^{\mathrm{c}}$ & 1 \\
\hline $\mathrm{SOC}$ & * & * & $*$ & * & $*$ & * & 1 \\
\hline
\end{tabular}




\section{Table 35. Percentage of fish passing McNary Dam during day period in 2009 based on a one-step Markov Chain analysis.}

[Data represent all fish that first approached the spillway during the day period. Species: YCH, Yearling Chinook salmon; STH, juvenile steelhead; SCH, subyearling Chinook salmon; SOC, Sockeye salmon. Area of Passage: PH\#1, turbine units 1-5; PH\#2, turbine units 6-10; PH\#3, turbine units 11-14; Spillway, spill bays 122; TSW, temporary spillway weir; $(\backslash)$ denotes the TSW was not installed; Superscripts denote number of transitions used to calculate percentage: a, greater than 100; b , 50-100; c , 10 to 50; (*), less than 10, which was insufficient sample size to calculate percentage]

\begin{tabular}{|c|c|c|c|c|c|c|c|}
\hline \multicolumn{8}{|c|}{ Area of Passage } \\
\hline \multirow[b]{2}{*}{ Species } & $\mathrm{PH} \# 1$ & $\mathrm{PH} \# 2$ & $\mathrm{PH} \# 3$ & \multicolumn{4}{|c|}{ Spillway } \\
\hline & & & & TSW 20 & TSW 19 & Bays & TSW 4 \\
\hline $\mathrm{YCH}$ & $23^{\mathrm{c}}$ & $24^{\mathrm{c}}$ & $31^{\mathrm{b}}$ & $13^{\mathrm{a}}$ & 1 & $64^{\mathrm{a}}$ & $7^{\mathrm{a}}$ \\
\hline STH & $11^{\mathrm{c}}$ & $10^{\mathrm{b}}$ & $12^{\mathrm{b}}$ & $27^{\mathrm{a}}$ & 1 & $33^{\mathrm{a}}$ & $15^{\mathrm{a}}$ \\
\hline $\mathrm{SCH}$ & $0^{\mathrm{c}}$ & $8^{\mathrm{c}}$ & $18^{\mathrm{c}}$ & $12^{\mathrm{a}}$ & $21^{\mathrm{a}}$ & $59^{\mathrm{a}}$ & 1 \\
\hline SOC & $*$ & $24^{\mathrm{c}}$ & $33^{\mathrm{c}}$ & $22^{\mathrm{a}}$ & 1 & $64^{\mathrm{a}}$ & $11^{\mathrm{a}}$ \\
\hline
\end{tabular}

\section{Table 36. Percentage of fish passing McNary Dam during night period in 2009 based on a one-step Markov Chain analysis.}

[Data represent all fish that first approached the spillway during the night period. Species: YCH, Yearling Chinook salmon; STH, juvenile steelhead; SCH, subyearling Chinook salmon; SOC, Sockeye salmon. Area of Passage: PH\#1, turbine units 1-5; PH\#2, turbine units 6-10; PH\#3, turbine units 11-14; Spillway, spill bays 122; TSW, temporary spillway weir; $(\backslash)$ denotes the TSW was not installed; Superscripts denote number of transitions used to calculate percentage: a, greater than 100 ; b , 50-100; c , 10 to 50; (*), less than 10, which was insufficient sample size to calculate percentage]

\begin{tabular}{|c|c|c|c|c|c|c|c|}
\hline \multirow[b]{3}{*}{ Species } & \multicolumn{6}{|c|}{ Area of Passage } & \\
\hline & \multirow[t]{2}{*}{ PH \#1 } & \multirow[t]{2}{*}{ PH \#2 } & \multirow[t]{2}{*}{$\mathrm{PH} \# 3$} & \multicolumn{4}{|c|}{ Spillway } \\
\hline & & & & TSW 20 & TSW 19 & Bays & TSW 4 \\
\hline $\mathrm{YCH}$ & $*$ & $40^{\mathrm{c}}$ & $43^{\mathrm{c}}$ & $12^{\mathrm{a}}$ & 1 & $65^{\mathrm{a}}$ & $9^{\mathrm{a}}$ \\
\hline STH & $7^{\mathrm{b}}$ & $5^{\mathrm{a}}$ & $16^{\mathrm{a}}$ & $14^{\mathrm{a}}$ & 1 & $47^{\mathrm{a}}$ & $12^{\mathrm{a}}$ \\
\hline $\mathrm{SCH}$ & $9^{c}$ & $17^{\mathrm{c}}$ & $49^{c}$ & $10^{\mathrm{a}}$ & $20^{\mathrm{a}}$ & $60^{\mathrm{a}}$ & 1 \\
\hline SOC & $*$ & $31^{\mathrm{c}}$ & $39^{c}$ & $25^{\mathrm{a}}$ & 1 & $59^{\mathrm{a}}$ & $13^{\mathrm{a}}$ \\
\hline
\end{tabular}


Table 37. Percentage of fish passing McNary Dam during day and night periods in 2006 based on a two-step Markov Chain analysis.

[Data represent all fish regardless of where they first approached the dam and include both day and night periods. Species: YCH, Yearling Chinook salmon; STH, juvenile steelhead; SCH, subyearling Chinook salmon; SOC, Sockeye salmon. Area of Passage: PH\#1, turbine units 1-5; PH\#2, turbine units 6-10; PH\#3, turbine units 11-14; Spillway, spill bays 1-22; Service Bay, equipment service bay on the south end of powerhouse; TSW, temporary spillway weir; (I) denotes the TSW was not installed; Superscripts denote number of transitions used to calculate percentage: a, greater than 100; b , 50-100; c , 10 to 50; $(*)$, less than 10 , which was insufficient sample size to calculate percentage]

\begin{tabular}{|c|c|c|c|c|c|c|c|c|c|c|c|c|c|c|c|c|c|}
\hline $\begin{array}{c}\text { Area of } \\
\text { Passage }\end{array}$ & \multicolumn{3}{|c|}{$\mathrm{PH} \# 1$} & \multicolumn{3}{|c|}{$\mathrm{PH} \# 2$} & \multicolumn{3}{|c|}{$\mathrm{PH} \# 3$} & \multicolumn{8}{|c|}{ Spillway } \\
\hline \multirow[b]{2}{*}{ Species } & $\begin{array}{l}\text { passing } \\
\text { PH\#1 } \\
\text { after } \\
\text { coming } \\
\text { from }\end{array}$ & $\begin{array}{l}\text { passing } \\
\text { PH\#1 } \\
\text { after } \\
\text { coming } \\
\text { from }\end{array}$ & $\begin{array}{l}\text { passing } \\
\text { PH\#1 } \\
\text { after } \\
\text { coming } \\
\text { from }\end{array}$ & $\begin{array}{l}\text { passing } \\
\text { PH\#2 } \\
\text { after } \\
\text { coming } \\
\text { from }\end{array}$ & $\begin{array}{l}\text { passing } \\
\text { PH\#2 } \\
\text { after } \\
\text { coming } \\
\text { from }\end{array}$ & $\begin{array}{l}\text { passing } \\
\text { PH\#2 } \\
\text { after } \\
\text { coming } \\
\text { from }\end{array}$ & $\begin{array}{l}\text { passing } \\
\mathrm{PH \# 3} \\
\text { after } \\
\text { coming } \\
\text { from }\end{array}$ & $\begin{array}{l}\text { passing } \\
\text { PH\#3 } \\
\text { after } \\
\text { coming } \\
\text { from }\end{array}$ & $\begin{array}{l}\text { passing } \\
\text { PH\#3 } \\
\text { after } \\
\text { coming } \\
\text { from }\end{array}$ & $\begin{array}{l}\text { passi } \\
\text { comir }\end{array}$ & $\begin{array}{l}\text { spillv } \\
\text { from }\end{array}$ & $\begin{array}{l}\text { ay afte } \\
\mathrm{H} \# 3\end{array}$ & & $\begin{array}{l}\text { passi } \\
\text { comir }\end{array}$ & $\begin{array}{l}g \text { spilly } \\
\text { from }\end{array}$ & $\begin{array}{l}\text { yy after } \\
\text { rebay }\end{array}$ & \\
\hline & & & & & & & & & & $\frac{\text { TSW }}{\underline{22}}$ & $\frac{\text { TSW }}{\underline{20}}$ & Bays & $\frac{\mathrm{TSW}}{\underline{4}}$ & $\frac{\text { TSW }}{\underline{22}}$ & $\frac{\text { TSW }}{\underline{20}}$ & Bays & $\frac{\text { TSW }}{\underline{4}}$ \\
\hline $\mathrm{YCH}$ & $24^{\mathrm{a}}$ & $39^{\mathrm{a}}$ & $11^{\mathrm{a}}$ & $16^{\mathrm{a}}$ & $48^{\mathrm{a}}$ & $17^{\mathrm{a}}$ & $21^{\mathrm{a}}$ & $44^{\mathrm{a}}$ & $6^{c}$ & 1 & 1 & $95^{\mathrm{a}}$ & 1 & 1 & 1 & $96^{\mathrm{a}}$ & 1 \\
\hline STH & $12^{\mathrm{b}}$ & $26^{\mathrm{a}}$ & $9^{a}$ & $5^{\mathrm{a}}$ & $20^{\mathrm{a}}$ & $4^{\mathrm{a}}$ & $4^{\mathrm{a}}$ & $22^{\mathrm{a}}$ & $8^{\mathrm{a}}$ & 1 & 1 & $66^{\mathrm{a}}$ & 1 & 1 & 1 & $61^{\mathrm{a}}$ & 1 \\
\hline $\mathrm{SCH}$ & $23^{\mathrm{a}}$ & $33^{\mathrm{a}}$ & $16^{\mathrm{a}}$ & $16^{\mathrm{a}}$ & $26^{\mathrm{a}}$ & $14^{\mathrm{a}}$ & $11^{\mathrm{a}}$ & $23^{a}$ & $6^{\mathrm{b}}$ & 1 & 1 & $92^{\mathrm{a}}$ & 1 & 1 & 1 & $46^{\mathrm{b}}$ & 1 \\
\hline SOC & $*$ & $14^{\mathrm{b}}$ & $51^{\mathrm{c}}$ & $46^{\mathrm{b}}$ & $46^{\mathrm{b}}$ & $34^{\mathrm{c}}$ & $49^{b}$ & $43^{c}$ & $*$ & 1 & 1 & 100 & 1 & 1 & 1 & $*$ & 1 \\
\hline
\end{tabular}




\section{Transition Probabilities Regardless of where Fish First Approached the Dam}

During 2006, the highest passage probabilities within each of the three powerhouse areas were observed for fish that had transitioned into each area from the forebay, not the adjoining areas to the north or south. The exception was sockeye salmon, and the inconsistent results were likely caused by the relatively low detection efficiency for this species in 2006 (table 37). In the spillway area, the highest passage proportions were observed for steelhead and subyearling Chinook salmon that had transitioned from the PH\#3 area. About the same proportion of yearling Chinook salmon passed the spillway area after transitioning from the forebay or the PH\#3 areas.

The addition of the TSWs during 2007 in the spillway area changed the trends that were observed in the powerhouse and spillway. For yearling Chinook salmon, the highest passage probabilities within each of the three powerhouse areas were observed for fish that had transitioned into each area from the forebay (table 38). This trend was not observed for the other three species. For steelhead, the passage probabilities for fish that passed one of the three powerhouse areas was about the same, and relatively low (0.03-0.09) compared to yearling Chinook salmon (0.09-0.36), regardless of which area they were in before passing the powerhouse. For sockeye and subyearling Chinook salmon, the results were inconsistent and no clear pattern was evident in the powerhouse areas. Within the spillway area, the highest passage probabilities were for fish that passed after transitioning from the PH\#3 area. The two-step analysis of the 2007 data also revealed some interesting trends in the passage probabilities through the two TSWs. Of the fish that passed TSW 22, the largest proportion had transitioned from the PH\#3 area before passing. The PH\#3 area is the area closest to the north and adjacent to the area where TSW 22 was located. Of the fish that passed through TSW 20, very few had been previously observed in the PH\#3 area. Instead, of the fish that passed TSW 20 the greatest proportion had transitioned from the forebay area.

The trends in passage probabilities observed in 2007 also were evident in 2008; however, moving the location of the TSWs within the spillway area had a noticeable effect on the proportion of fish passing through the TSWs (table 39). Passage through the spillway area was still relatively high compared to 2006, but within the spillway area, the proportion of fish passing through the two TSWs decreased and the proportion passing the standard spill bays increased. There was variability in the results among species, but in general, the proportions of fish that passed the southernmost TSW (previously TSW 22 but now TSW 20) after transitioning from the PH\#3 area decreased. We also observed a general decrease in the proportion of fish passing TSW 20 after transitioning from the forebay area. The proportion of fish passing the PH\#3 area after transitioning from the spillway area increased in 2008, indicating that less fish passed the spillway area and instead transitioned into the $\mathrm{PH \# 3}$ area before passing the dam.

The proportion of fish that passed the TSWs after transitioning from either the $\mathrm{PH \# 3}$ or the forebay area was affected by having only one TSW located in the southern portion of the spillway area during the spring study period of 2009 (table 40). Having only one TSW available on the southern end of the spillway, rather than two, likely contributed to the differences in passage proportion observed in 2009 compared to 2007 and 2008. An additional contributing factor to differences in passage proportion observed in 2009 compared to 2007 was likely the increased distance between the powerhouse and the southernmost TSW. For yearling Chinook salmon and steelhead, the proportion of fish that passed through TSW 20 after transitioning from the PH\#3 area in 2009 was less than what was observed in 2008 for TSW 20. 
Table 38. Percentage of fish passing McNary Dam during day and night periods in 2007 based on a two-step Markov Chain analysis.

[Data represent all fish regardless of where they first approached the dam and includes both day and night periods. Species: YCH, Yearling Chinook salmon; STH, juvenile steelhead; SCH, subyearling Chinook salmon; SOC, Sockeye salmon. Area of Passage: PH\#1, turbine units 1-5; PH\#2, turbine units 6-10; PH\#3, turbine units 11-14; Spillway, spill bays 1-22; Service Bay, equipment service bay on the south end of powerhouse; TSW, temporary spillway weir; ( ) denotes the TSW was not installed; Superscripts denote number of transitions used to calculate percentage: a, greater than 100; b , 50100 ; c 10 to $50 ;(*)$, less than 10 , which was insufficient sample size to calculate percentage]

\begin{tabular}{|c|c|c|c|c|c|c|c|c|c|c|c|c|c|c|c|c|c|}
\hline $\begin{array}{c}\text { Area of } \\
\text { Passage. }\end{array}$ & \multicolumn{3}{|c|}{$\mathrm{PH} \# 1$} & \multicolumn{3}{|c|}{$\mathrm{PH} \# 2$} & \multicolumn{3}{|c|}{$\mathrm{PH} \# 3$} & \multicolumn{8}{|c|}{ Spillway } \\
\hline \multirow[b]{2}{*}{ Species } & $\begin{array}{l}\text { passing } \\
\text { PH\#1 } \\
\text { after } \\
\text { coming } \\
\text { from }\end{array}$ & $\begin{array}{l}\text { passing } \\
\text { PH\#1 } \\
\text { after } \\
\text { coming } \\
\text { from }\end{array}$ & $\begin{array}{l}\text { passing } \\
\text { PH\#1 } \\
\text { after } \\
\text { coming } \\
\text { from }\end{array}$ & $\begin{array}{l}\text { passing } \\
\text { PH\#2 } \\
\text { after } \\
\text { coming } \\
\text { from }\end{array}$ & $\begin{array}{l}\text { passing } \\
\text { PH\#2 } \\
\text { after } \\
\text { coming } \\
\text { from }\end{array}$ & $\begin{array}{l}\text { passing } \\
\text { PH\#2 } \\
\text { after } \\
\text { coming } \\
\text { from }\end{array}$ & $\begin{array}{l}\text { passing } \\
\text { PH\#3 } \\
\text { after } \\
\text { coming } \\
\text { from }\end{array}$ & $\begin{array}{l}\text { passing } \\
\text { PH\#3 } \\
\text { after } \\
\text { coming } \\
\text { from }\end{array}$ & $\begin{array}{l}\text { passing } \\
\text { PH\#3 } \\
\text { after } \\
\text { coming } \\
\text { from }\end{array}$ & $\begin{array}{l}\text { passir } \\
\text { comin }\end{array}$ & $\begin{array}{l}\text { spillv } \\
\text { from }\end{array}$ & $\begin{array}{l}y \text { afte } \\
\text { H\#3 }\end{array}$ & & $\begin{array}{l}\text { passi } \\
\text { comir }\end{array}$ & $\begin{array}{l}g \text { spilly } \\
\text { from }\end{array}$ & $\begin{array}{l}\text { y after } \\
\text { rebay }\end{array}$ & \\
\hline & & & & & & & & & & $\frac{\text { TSW }}{\underline{22}}$ & $\frac{\text { TSW }}{\underline{20}}$ & Bays & $\frac{\mathrm{TSW}}{\underline{4}}$ & $\frac{\text { TSW }}{\underline{22}}$ & $\frac{\text { TSW }}{\underline{20}}$ & Bays & $\frac{\text { TSW }}{\underline{4}}$ \\
\hline $\mathrm{YCH}$ & $24^{\mathrm{a}}$ & $32^{\mathrm{a}}$ & $15^{\mathrm{a}}$ & $23^{a}$ & $36^{\mathrm{a}}$ & $26^{\mathrm{a}}$ & $9^{a}$ & $30^{\mathrm{a}}$ & $25^{\mathrm{b}}$ & $76^{\mathrm{a}}$ & $9^{a}$ & $12^{\mathrm{a}}$ & 1 & $13^{\mathrm{a}}$ & $16^{\mathrm{a}}$ & $58^{\mathrm{a}}$ & 1 \\
\hline STH & $9^{a}$ & $7^{\mathrm{a}}$ & $4^{a}$ & $4^{\mathrm{a}}$ & $5^{\mathrm{a}}$ & $5^{\mathrm{a}}$ & $3^{\mathrm{a}}$ & $7^{\mathrm{a}}$ & $3^{a}$ & $68^{\mathrm{a}}$ & $12^{\mathrm{a}}$ & $7^{\mathrm{a}}$ & 1 & $18^{\mathrm{a}}$ & $28^{\mathrm{a}}$ & $27^{\mathrm{a}}$ & $\backslash$ \\
\hline $\mathrm{SCH}$ & $20^{\mathrm{a}}$ & $33^{\mathrm{a}}$ & $17^{\mathrm{a}}$ & $18^{\mathrm{a}}$ & $27^{\mathrm{a}}$ & $21^{\mathrm{a}}$ & $13^{\mathrm{a}}$ & $15^{\mathrm{a}}$ & $18^{\mathrm{b}}$ & $56^{\mathrm{a}}$ & $13^{\mathrm{a}}$ & $22^{\mathrm{a}}$ & 1 & $22^{\mathrm{a}}$ & $27^{\mathrm{a}}$ & $31^{\mathrm{a}}$ & 1 \\
\hline SOC & $38^{\mathrm{b}}$ & $40^{\mathrm{a}}$ & $33^{\mathrm{a}}$ & $33^{\mathrm{a}}$ & $41^{\mathrm{b}}$ & $47^{\mathrm{b}}$ & $19^{\mathrm{b}}$ & $16^{\mathrm{b}}$ & $70^{\mathrm{c}}$ & $59^{c}$ & $17^{\mathrm{c}}$ & $10^{\mathrm{c}}$ & 1 & $17^{\mathrm{c}}$ & $20^{\mathrm{c}}$ & $9^{c}$ & 1 \\
\hline
\end{tabular}


Table 39. Percentage of fish passing McNary Dam during day and night periods in 2008 based on a two-step Markov Chain analysis.

[Data represent all fish regardless of where they first approached the dam and includes both day and night periods. Species: YCH, Yearling Chinook salmon; STH, juvenile steelhead; SCH, subyearling Chinook salmon; SOC, Sockeye salmon. Area of Passage: PH\#1, turbine units 1-5; PH\#2, turbine units 6-10; PH\#3, turbine units 11-14; Spillway, spill bays 1-22; Service Bay, equipment service bay on the south end of powerhouse; TSW, temporary spillway weir; ( ) denotes the TSW was not installed; Superscripts denote number of transitions used to calculate percentage: a, greater than 100; b , 50$100 ;$ c, 10 to $50 ;(*)$, less than 10 , which was insufficient sample size to calculate percentage]

\begin{tabular}{|c|c|c|c|c|c|c|c|c|c|c|c|c|c|c|c|c|c|}
\hline $\begin{array}{c}\text { Area of } \\
\text { Passage: }\end{array}$ & \multicolumn{3}{|c|}{$\mathrm{PH} \# 1$} & \multicolumn{3}{|c|}{$\mathrm{PH} \# 2$} & \multicolumn{3}{|c|}{$\mathrm{PH} \# 3$} & \multicolumn{8}{|c|}{ Spillway } \\
\hline \multirow[b]{2}{*}{ Species } & $\begin{array}{l}\text { passing } \\
\text { PH\#1 } \\
\text { after } \\
\text { coming } \\
\text { from }\end{array}$ & $\begin{array}{l}\text { passing } \\
\mathrm{PH \# 1} \\
\text { after } \\
\text { coming } \\
\text { from }\end{array}$ & $\begin{array}{l}\text { passing } \\
\text { PH\#1 } \\
\text { after } \\
\text { coming } \\
\text { from }\end{array}$ & $\begin{array}{l}\text { passing } \\
\text { PH\#2 } \\
\text { after } \\
\text { coming } \\
\text { from }\end{array}$ & $\begin{array}{l}\text { passing } \\
\text { PH\#2 } \\
\text { after } \\
\text { coming } \\
\text { from }\end{array}$ & $\begin{array}{l}\text { passing } \\
\text { PH\#2 } \\
\text { after } \\
\text { coming } \\
\text { from }\end{array}$ & $\begin{array}{l}\text { passing } \\
\text { PH\#3 } \\
\text { after } \\
\text { coming } \\
\text { from }\end{array}$ & $\begin{array}{l}\text { passing } \\
\text { PH\#3 } \\
\text { after } \\
\text { coming } \\
\text { from }\end{array}$ & $\begin{array}{l}\text { passing } \\
\text { PH\#3 } \\
\text { after } \\
\text { coming } \\
\text { from }\end{array}$ & $\begin{array}{l}\text { passir } \\
\text { comin }\end{array}$ & $\begin{array}{l}\text { spilln } \\
\text { from }\end{array}$ & $\begin{array}{l}y \text { after } \\
\text { H\#3 }\end{array}$ & & $\begin{array}{l}\text { passi } \\
\text { comir }\end{array}$ & $\begin{array}{l}\text { spilly } \\
\text { from } f\end{array}$ & $\begin{array}{l}\text { y after } \\
\text { rebay }\end{array}$ & \\
\hline & & & & & & & & & & $\frac{\text { TSW }}{\underline{20}}$ & $\frac{\text { TSW }}{\underline{19}}$ & Bays & $\frac{\text { TSW }}{\underline{4}}$ & $\frac{\text { TSW }}{\underline{20}}$ & $\frac{\text { TSW }}{\underline{19}}$ & Bays & $\frac{\text { TSW }}{\underline{4}}$ \\
\hline $\mathrm{YCH}$ & $18^{\mathrm{c}}$ & $22^{\mathrm{b}}$ & $18^{\mathrm{a}}$ & $19^{\mathrm{a}}$ & $26^{\mathrm{b}}$ & $19^{\mathrm{b}}$ & $21^{\mathrm{a}}$ & $15^{b}$ & $39^{b}$ & $34^{\mathrm{a}}$ & $17^{\mathrm{a}}$ & $34^{\mathrm{a}}$ & 1 & $13^{\mathrm{a}}$ & $30^{\mathrm{a}}$ & $32^{\mathrm{a}}$ & 1 \\
\hline STH & $9^{b}$ & $21^{\mathrm{a}}$ & $10^{\mathrm{a}}$ & $9^{a}$ & $2^{\mathrm{b}}$ & $5^{\mathrm{a}}$ & $6^{\mathrm{a}}$ & $7^{\mathrm{a}}$ & $18^{\mathrm{a}}$ & $38^{\mathrm{a}}$ & $16^{\mathrm{a}}$ & $21^{\mathrm{a}}$ & 1 & $10^{\mathrm{a}}$ & $21^{\mathrm{a}}$ & $22^{\mathrm{a}}$ & 1 \\
\hline $\mathrm{SCH}$ & $17^{\mathrm{a}}$ & $31^{\mathrm{a}}$ & $18^{\mathrm{a}}$ & $17^{\mathrm{a}}$ & $22^{\mathrm{a}}$ & $3^{b}$ & $14^{\mathrm{a}}$ & $13^{\mathrm{b}}$ & $28^{\mathrm{b}}$ & $21^{\mathrm{a}}$ & $16^{\mathrm{a}}$ & $51^{\mathrm{a}}$ & 1 & $18^{\mathrm{a}}$ & $21^{\mathrm{a}}$ & $32^{\mathrm{a}}$ & 1 \\
\hline $\mathrm{SOC}$ & $*$ & $40^{\mathrm{c}}$ & $*$ & $88^{c}$ & $84^{c}$ & $*$ & $*$ & $33^{c}$ & $*$ & $0^{\mathrm{c}}$ & $0^{\mathrm{c}}$ & $100^{c}$ & 1 & $*$ & $*$ & $*$ & 1 \\
\hline
\end{tabular}


Table 40. Percentage of fish passing McNary Dam during day and night periods in 2009 based on a two-step Markov Chain analysis.

[Data represent all fish regardless of where they first approached the dam and includes both day and night periods. Species: YCH, Yearling Chinook salmon; STH, juvenile steelhead; SCH, subyearling Chinook salmon; SOC, Sockeye salmon. Area of Passage: PH\#1, turbine units 1-5; PH\#2, turbine units 6-10; PH\#3, turbine units 11-14; Spillway, spill bays 1-22; Service Bay, equipment service bay on the south end of powerhouse; TSW, temporary spillway weir; ( ) denotes the TSW was not installed; Superscripts denote number of transitions used to calculate percentage: a, greater than 100; b , 50$100 ;$ c, 10 to $50 ;(*)$, less than 10 , which was insufficient sample size to calculate percentage]

\begin{tabular}{|c|c|c|c|c|c|c|c|c|c|c|c|c|c|c|c|c|c|}
\hline $\begin{array}{c}\text { Area of } \\
\text { Passage: }\end{array}$ & \multicolumn{3}{|c|}{$\mathrm{PH} \# 1$} & \multicolumn{3}{|c|}{$\mathrm{PH} \# 2$} & \multicolumn{3}{|c|}{$\mathrm{PH} \# 3$} & \multicolumn{8}{|c|}{ Spillway } \\
\hline \multirow[b]{2}{*}{ Species } & $\begin{array}{l}\text { passing } \\
\text { PH\#1 } \\
\text { after } \\
\text { coming } \\
\text { from }\end{array}$ & $\begin{array}{l}\text { passing } \\
\mathrm{PH \# 1} \\
\text { after } \\
\text { coming } \\
\text { from }\end{array}$ & $\begin{array}{l}\text { passing } \\
\text { PH\#1 } \\
\text { after } \\
\text { coming } \\
\text { from }\end{array}$ & $\begin{array}{l}\text { passing } \\
\text { PH\#2 } \\
\text { after } \\
\text { coming } \\
\text { from }\end{array}$ & $\begin{array}{l}\text { passing } \\
\text { PH\#2 } \\
\text { after } \\
\text { coming } \\
\text { from }\end{array}$ & $\begin{array}{l}\text { passing } \\
\text { PH\#2 } \\
\text { after } \\
\text { coming } \\
\text { from }\end{array}$ & $\begin{array}{l}\text { passing } \\
\text { PH\#3 } \\
\text { after } \\
\text { coming } \\
\text { from }\end{array}$ & $\begin{array}{l}\text { passing } \\
\text { PH\#3 } \\
\text { after } \\
\text { coming } \\
\text { from }\end{array}$ & $\begin{array}{l}\text { passing } \\
\text { PH\#3 } \\
\text { after } \\
\text { coming } \\
\text { from }\end{array}$ & $\begin{array}{l}\text { passi } \\
\text { comir }\end{array}$ & $\begin{array}{l}\text { spillw } \\
\text { from } F\end{array}$ & $\begin{array}{l}y \text { after } \\
-\# 33\end{array}$ & & $\begin{array}{l}\text { passi } \\
\text { comir }\end{array}$ & $\begin{array}{l}9 \text { spillw } \\
\text { from } f\end{array}$ & $\begin{array}{l}\text { y after } \\
\text { rebay }\end{array}$ & \\
\hline & & & & & & & & & & $\frac{\text { TSW }}{\underline{20}}$ & $\frac{\text { TSW }}{\underline{19}}$ & Bays & $\frac{\text { TSW }}{\underline{4}}$ & $\frac{\text { TSW }}{\underline{20}}$ & $\frac{\text { TSW }}{\underline{19}}$ & Bays & $\frac{\text { TSW }}{\underline{4}}$ \\
\hline $\mathrm{YCH}$ & $23^{\mathrm{a}}$ & $27^{\mathrm{a}}$ & $15^{\mathrm{a}}$ & $14^{\mathrm{a}}$ & $30^{\mathrm{a}}$ & $15^{\mathrm{a}}$ & $21^{\mathrm{a}}$ & $40^{\mathrm{a}}$ & $35^{\mathrm{b}}$ & $23^{\mathrm{a}}$ & 1 & $64^{\mathrm{a}}$ & $3^{\mathrm{a}}$ & $12^{\mathrm{a}}$ & 1 & $65^{\mathrm{a}}$ & $8^{\mathrm{a}}$ \\
\hline STH & $10^{\mathrm{a}}$ & $11^{\mathrm{a}}$ & $10^{\mathrm{a}}$ & $7^{\mathrm{a}}$ & $18^{\mathrm{a}}$ & $7^{\mathrm{a}}$ & $7^{\mathrm{a}}$ & $15^{\mathrm{a}}$ & $11^{\mathrm{a}}$ & $37^{\mathrm{a}}$ & 1 & $32^{\mathrm{a}}$ & $8^{\mathrm{a}}$ & $16^{\mathrm{a}}$ & 1 & $43^{\mathrm{a}}$ & $14^{\mathrm{a}}$ \\
\hline $\mathrm{SCH}$ & $14^{\mathrm{a}}$ & $27^{\mathrm{a}}$ & $12^{\mathrm{a}}$ & $9^{\mathrm{a}}$ & $16^{\mathrm{a}}$ & $12^{\mathrm{a}}$ & $22^{\mathrm{a}}$ & $44^{\mathrm{a}}$ & $36^{\mathrm{b}}$ & $33^{\mathrm{a}}$ & $10^{\mathrm{a}}$ & $49^{\mathrm{a}}$ & 1 & $11^{\mathrm{a}}$ & $21^{\mathrm{a}}$ & $60^{\mathrm{a}}$ & 1 \\
\hline $\mathrm{SOC}$ & $*$ & $96^{\mathrm{a}}$ & $13^{\mathrm{a}}$ & $16^{\mathrm{a}}$ & $96^{\mathrm{a}}$ & $22^{\mathrm{a}}$ & $12^{\mathrm{a}}$ & $64^{\mathrm{a}}$ & $63^{c}$ & $30^{\mathrm{a}}$ & 1 & $64^{\mathrm{a}}$ & $1^{\mathrm{a}}$ & $24^{\mathrm{a}}$ & 1 & $61^{\mathrm{a}}$ & $12^{\mathrm{a}}$ \\
\hline
\end{tabular}


However, the proportions that passed through TSW 20 during 2009 (this was the TSW closest to the powerhouse) were not as high as what was observed in 2007 for TSW 22 (located two bays closer to the powerhouse). Passage of sockeye salmon through TSWs appeared to be also dependent on the proximity of the TSW to the powerhouse. In 2007, 0.59 of the sockeye salmon that passed through TSW 22 had transitioned from the PH\#3 area in the powerhouse. In 2008, very few sockeye salmon that passed TSW 20 had transitioned from the PH\#3 area (10 to 50 transitions) and the probability of passing was 0.00 . In 2009, detection efficiency increased for sockeye salmon and the number of transitions from the powerhouse to the spillway increased to more than 100. The proportion of fish that passed TSW 20 after transitioning from the PH\#3 area was 0.30 in 2009. This was 0.29 less than the proportion that passed TSW 22 in 2007 after transitioning from the PH\#3 area.

We conducted further analysis using the two-step methods to investigate how passage proportions might be influenced if the fish passed during the day compared to the night. The overall trends in passage proportions were similar to those observed for fish regardless of the time of day they passed. The results are presented in appendix $\mathrm{C}$.

\section{Transition Probabilities after First Approaching the Powerhouse}

In 2006, a high proportion of fish first approached the powerhouse and passed through the spillway area during the day and night periods combined after transitioning from the PH\#3 area in the powerhouse. Of the fish that passed the spillway after first approaching the powerhouse, 0.95 of the yearling Chinook salmon, 0.66 of the steelhead, 0.92 of the subyearling Chinook salmon, and 1.00 of the sockeye salmon transitioned from PH\#3 (table 41). There were very few fish that first approached the powerhouse and then passed the spillway area after transitioning from the forebay. This result indicates that few fish approached the powerhouse and swam back upstream and over to the spillway area before passing the dam. Instead, fish likely approached the powerhouse and moved laterally along the powerhouse and transitioned into the spillway area before passing the dam. The proportion of fish (with the exception of sockeye salmon) that passed within each of the areas in the powerhouse (PH\#1, $\mathrm{PH} 22$ and $\mathrm{PH \# 3}$ ) after first approaching the powerhouse was higher for fish that transitioned from the forebay compared to fish that transitioned from adjoining areas across the face of the dam before passing. This result indicated that fish passing the powerhouse did so during their first approach to the dam and fewer fish passing the powerhouse did so after moving laterally across the powerhouse. If fish moved laterally, they appeared to continue to move to the spillway where a large portion then passed the dam. The passage proportions for sockeye salmon were variable across the powerhouse, likely due to lower detection efficiencies during 2006 for this species compared to the other species.

Similar trends were observed in the powerhouse during 2007 when the TSWs were installed in the spillway area. In the spillway, similar to the results of the one-step analysis, the addition of the TSWs increased the proportion of fish passing the spillway area, especially for steelhead. The two-step analysis showed a majority of the fish passing the spillway area after transitioning from the PH\#3 area in the powerhouse (table 42). Once again, there were very few fish that first approached the powerhouse and then passed the spillway area after transitioning from the forebay. This result indicates that few fish approached the powerhouse and traveled back upstream and over to the spillway area before passing the dam. Instead, fish likely approached the powerhouse and moved laterally along the powerhouse and transitioned into the spillway area before passing the dam. As was observed in 2006, the proportion of fish that first approached the powerhouse and passed the PH\#3 area after transitioning from the spillway was relatively low. This result indicates that once fish transitioned into the spillway, the majority of them passed the dam and very few transitioned back into the powerhouse. 
Table 41. Percentage of fish passing McNary Dam during day and night periods in 2006 based on a two-step Markov Chain analysis.

[Data represent all fish that first approached the powerhouse and includes both day and night periods. Species: YCH, Yearling Chinook salmon; STH, juvenile steelhead; SCH, subyearling Chinook salmon; SOC, Sockeye salmon. Area of Passage: PH\#1, turbine units 1-5; PH\#2, turbine units 6-10; PH\#3, turbine units 11-14; Spillway, spill bays 1-22; Service Bay, equipment service bay on the south end of powerhouse; TSW, temporary spillway weir; (\) denotes the TSW was not installed; Superscripts denote number of transitions used to calculate percentage: a, greater than 100; b , 50-100; c, 10 to 50; $(*)$, less than 10 , which was insufficient sample size to calculate percentage

\begin{tabular}{|c|c|c|c|c|c|c|c|c|c|c|c|c|c|c|c|c|c|}
\hline $\begin{array}{c}\text { Area of } \\
\text { Passage }\end{array}$ & \multicolumn{3}{|c|}{$\mathrm{PH} \# 1$} & \multicolumn{3}{|c|}{$\mathrm{PH} \# 2$} & \multicolumn{3}{|c|}{$\mathrm{PH} \# 3$} & \multicolumn{8}{|c|}{ Spillway } \\
\hline \multirow[b]{2}{*}{ Species } & $\begin{array}{l}\text { passing } \\
\mathrm{PH \# 1} \\
\text { after } \\
\text { coming } \\
\text { from }\end{array}$ & $\begin{array}{l}\text { passing } \\
\text { PH\#1 } \\
\text { after } \\
\text { coming } \\
\text { from }\end{array}$ & $\begin{array}{l}\text { passing } \\
\text { PH\#1 } \\
\text { after } \\
\text { coming } \\
\text { from }\end{array}$ & $\begin{array}{l}\text { passing } \\
\text { PH\#2 } \\
\text { after } \\
\text { coming } \\
\text { from }\end{array}$ & $\begin{array}{l}\text { passing } \\
\text { PH\#2 } \\
\text { after } \\
\text { coming } \\
\text { from }\end{array}$ & $\begin{array}{l}\text { passing } \\
\text { PH\#2 } \\
\text { after } \\
\text { coming } \\
\text { from }\end{array}$ & $\begin{array}{l}\text { passing } \\
\mathrm{PH \# 3} \\
\text { after } \\
\text { coming } \\
\text { from }\end{array}$ & $\begin{array}{l}\text { passing } \\
\text { PH\#3 } \\
\text { after } \\
\text { coming } \\
\text { from }\end{array}$ & $\begin{array}{l}\text { passing } \\
\text { PH\#3 } \\
\text { after } \\
\text { coming } \\
\text { from }\end{array}$ & $\begin{array}{l}\text { passi } \\
\text { comin }\end{array}$ & $\begin{array}{l}\text { spillw } \\
\text { from } F\end{array}$ & $\begin{array}{l}\text { y afte } \\
\text { H\#3 }\end{array}$ & & $\begin{array}{l}\text { passi } \\
\text { comir }\end{array}$ & $\begin{array}{l}g \text { spillu } \\
\text { from }\end{array}$ & $\begin{array}{l}\text { y after } \\
\text { rebay }\end{array}$ & \\
\hline & & & & & & & & & & $\frac{\text { TSW }}{\underline{22}}$ & $\frac{\text { TSW }}{\underline{20}}$ & Bays & $\frac{\mathrm{TSW}}{\underline{4}}$ & $\frac{\text { TSW }}{\underline{22}}$ & $\frac{\text { TSW }}{\underline{20}}$ & Bays & $\frac{\text { TSW }}{\underline{4}}$ \\
\hline $\mathrm{YCH}$ & $24^{\mathrm{a}}$ & $39^{\mathrm{a}}$ & $10^{\mathrm{a}}$ & $16^{\mathrm{a}}$ & $48^{\mathrm{a}}$ & $16^{\mathrm{a}}$ & $20^{\mathrm{a}}$ & $44^{\mathrm{a}}$ & $*$ & 1 & 1 & $95^{\mathrm{a}}$ & 1 & 1 & 1 & $*$ & 1 \\
\hline STH & $14^{\mathrm{b}}$ & $26^{\mathrm{a}}$ & $7^{\mathrm{a}}$ & $6^{\mathrm{a}}$ & $20^{\mathrm{a}}$ & $4^{\mathrm{a}}$ & $4^{\mathrm{a}}$ & $22^{\mathrm{a}}$ & $6^{\mathrm{b}}$ & 1 & 1 & $66^{\mathrm{a}}$ & 1 & 1 & 1 & $*$ & $\backslash$ \\
\hline $\mathrm{SCH}$ & $22^{\mathrm{a}}$ & $33^{\mathrm{a}}$ & $15^{\mathrm{a}}$ & $16^{\mathrm{a}}$ & $26^{\mathrm{a}}$ & $16^{\mathrm{a}}$ & $12^{\mathrm{a}}$ & $23^{a}$ & $16^{\mathrm{c}}$ & 1 & 1 & $92^{\mathrm{a}}$ & 1 & 1 & 1 & $*$ & 1 \\
\hline SOC & $*$ & $14^{\mathrm{b}}$ & $51^{\mathrm{c}}$ & $47^{\mathrm{b}}$ & $46^{\mathrm{b}}$ & $38^{\mathrm{c}}$ & $51^{\mathrm{c}}$ & $43^{c}$ & $*$ & 1 & 1 & 100 & 1 & 1 & 1 & $*$ & 1 \\
\hline
\end{tabular}


Table 42. Percentage of fish passing McNary Dam during day and night periods in 2007 based on a two-step Markov Chain analysis.

[Data represent all fish that first approached the powerhouse and includes both day and night periods. Species: YCH, Yearling Chinook salmon; STH, juvenile steelhead; SCH, subyearling Chinook salmon; SOC, Sockeye salmon. Area of Passage: PH\#1, turbine units 1-5; PH\#2, turbine units 6-10; PH\#3, turbine units 11-14; Spillway, spill bays 1-22; Service Bay, equipment service bay on the south end of powerhouse; TSW, temporary spillway weir; (\) denotes the TSW was not installed; Superscripts denote number of transitions used to calculate percentage: a, greater than 100; b , 50-100; c , 10 to 50; $(*)$, less than 10 , which was insufficient sample size to calculate percentage]

\begin{tabular}{|c|c|c|c|c|c|c|c|c|c|c|c|c|c|c|c|c|c|}
\hline $\begin{array}{c}\text { Area of } \\
\text { Passage: }\end{array}$ & \multicolumn{3}{|c|}{$\mathrm{PH} \# 1$} & \multicolumn{3}{|c|}{$\mathrm{PH} \# 2$} & \multicolumn{3}{|c|}{$\mathrm{PH} \# 3$} & \multicolumn{8}{|c|}{ Spillway } \\
\hline \multirow[b]{2}{*}{ Species } & $\begin{array}{l}\text { passing } \\
\text { PH\#1 } \\
\text { after } \\
\text { coming } \\
\text { from }\end{array}$ & $\begin{array}{l}\text { passing } \\
\mathrm{PH \# 1} \\
\text { after } \\
\text { coming } \\
\text { from }\end{array}$ & $\begin{array}{l}\text { passing } \\
\text { PH\#1 } \\
\text { after } \\
\text { coming } \\
\text { from }\end{array}$ & $\begin{array}{l}\text { passing } \\
\text { PH\#2 } \\
\text { after } \\
\text { coming } \\
\text { from }\end{array}$ & $\begin{array}{l}\text { passing } \\
\text { PH\#2 } \\
\text { after } \\
\text { coming } \\
\text { from }\end{array}$ & $\begin{array}{l}\text { passing } \\
\text { PH\#2 } \\
\text { after } \\
\text { coming } \\
\text { from }\end{array}$ & $\begin{array}{l}\text { passing } \\
\text { PH\#3 } \\
\text { after } \\
\text { coming } \\
\text { from }\end{array}$ & $\begin{array}{l}\text { passing } \\
\text { PH\#3 } \\
\text { after } \\
\text { coming } \\
\text { from }\end{array}$ & $\begin{array}{l}\text { passing } \\
\text { PH\#3 } \\
\text { after } \\
\text { coming } \\
\text { from }\end{array}$ & $\begin{array}{l}\text { passir } \\
\text { comin }\end{array}$ & $\begin{array}{l}\text { spilln } \\
\text { from }\end{array}$ & $\begin{array}{l}y \text { after } \\
\text { H\#3 }\end{array}$ & & $\begin{array}{l}\text { passi } \\
\text { comir }\end{array}$ & $\begin{array}{l}\text { spilly } \\
\text { from } f\end{array}$ & $\begin{array}{l}\text { y after } \\
\text { rebay }\end{array}$ & \\
\hline & & & & & & & & & & $\frac{\text { TSW }}{\underline{22}}$ & $\frac{\text { TSW }}{\underline{20}}$ & Bays & $\frac{\text { TSW }}{\underline{4}}$ & $\frac{\text { TSW }}{\underline{22}}$ & $\frac{\text { TSW }}{\underline{20}}$ & Bays & $\frac{\text { TSW }}{\underline{4}}$ \\
\hline $\mathrm{YCH}$ & $24^{\mathrm{a}}$ & $32^{\mathrm{a}}$ & $16^{\mathrm{a}}$ & $23^{\mathrm{a}}$ & $36^{\mathrm{a}}$ & $26^{\mathrm{a}}$ & $9^{\mathrm{a}}$ & $30^{\mathrm{a}}$ & $*$ & $78^{\mathrm{a}}$ & $7^{\mathrm{a}}$ & $13^{\mathrm{a}}$ & 1 & $*$ & * & $*$ & 1 \\
\hline STH & $8^{\mathrm{a}}$ & $7^{\mathrm{a}}$ & $4^{\mathrm{a}}$ & $3^{a}$ & $5^{\mathrm{a}}$ & $4^{\mathrm{a}}$ & $3^{\mathrm{a}}$ & $7^{\mathrm{a}}$ & $3^{b}$ & $69^{a}$ & $13^{\mathrm{a}}$ & $7^{\mathrm{a}}$ & 1 & $*$ & $*$ & $*$ & 1 \\
\hline $\mathrm{SCH}$ & $21^{\mathrm{a}}$ & $33^{\mathrm{a}}$ & $17^{\mathrm{a}}$ & $19^{\mathrm{a}}$ & $27^{\mathrm{a}}$ & $22^{\mathrm{a}}$ & $13^{\mathrm{a}}$ & $15^{\mathrm{a}}$ & $25^{\mathrm{c}}$ & $56^{\mathrm{a}}$ & $14^{\mathrm{a}}$ & $21^{\mathrm{a}}$ & 1 & $*$ & $*$ & $*$ & 1 \\
\hline $\mathrm{SOC}$ & $38^{\mathrm{b}}$ & $40^{\mathrm{a}}$ & $33^{\mathrm{a}}$ & $32^{\mathrm{a}}$ & $41^{b}$ & $47^{\mathrm{b}}$ & $20^{\mathrm{b}}$ & $15^{\mathrm{b}}$ & $*$ & $54^{\mathrm{c}}$ & $19^{c}$ & $12^{\mathrm{c}}$ & 1 & $*$ & $*$ & * & 1 \\
\hline
\end{tabular}


The overall passage trends observed in 2007 also were observed in 2008 and 2009 for fish that first approached the powerhouse (tables 43 and 44). Similar to the results of the one-step analysis, moving the locations of the TSWs in 2008 and 2009 influenced passage within the spillway area. Of the fish that first approached the powerhouse and then passed the spillway during 2007, 0.85 of the yearling Chinook salmon, 0.82 of the steelhead, 0.70 of the subyearling Chinook salmon, and 0.73 of the sockeye salmon passed through the two TSWs in bays 20 and 22 after transitioning from the PH\#3 area. Less than 0.21 of the fish passing through the spillway after transitioning from the PH\#3 area did so through the other bays within the spillway. In 2008, 0.52 of the yearling Chinook salmon, 0.54 of the steelhead, and 0.36 of the subyearling Chinook salmon that had transitioned from the PH\#3 area passed the two TSWs in bays 20 and 19. The proportion of fish passing through the other bays in the spillway after transitioning from the PH\#3 area during 2008 increased to 0.36 for yearling Chinook salmon, 0.21 for steelhead, and 0.51 for subyearling Chinook salmon. In 2009, when one TSW was present in the southern portion of the spillway, the number of fish first detected in the powerhouse that entered and passed through the spillway was again high for fish that transitioned from the PH\#3 area, but the proportion of fish passing through the TSW decreased and the proportion of fish passing through the other bays increased.

We conducted further analysis using the two-step methods to investigate how passage proportions for fish that first approach the powerhouse might be influenced if the fish passed during the day compared to the night. The overall trends in passage proportions were similar to those observed for fish regardless of the time of day they passed. The results are presented in appendix D.

\section{Transition Probabilities after First Approaching the Spillway}

The two-step analysis of fish that first approached the spillway during the day and night periods combined indicated that powerhouse passage after lateral movement of fish from the spillway to $\mathrm{PH \# 3}$ was relatively low for all species. During 2006, for fish that first approached the spillway, 0.11 (or less depending on species) passed the PH\#3 area after transitioning from the spillway (table 45). During 2007, lateral movement from the spillway to the powerhouse for fish that passed the PH\#3 area was still relatively low at 0.25 or less (except for sockeye salmon; table 46). In contrast, the number of fish that passed the spillway area after transitioning from the powerhouse area (PH\#3) was generally higher in 2007 than in 2006. In 2006, 0.68 of juvenile steelhead and 0.94 of subyearling Chinook salmon (other species had insufficient sample size) passed the spillway after transitioning from the PH\#3 area. With the addition of the TSWs in 2007, 0.89 of the yearling Chinook salmon, 0.78 of the steelhead, and 0.93 of the subyearling Chinook salmon passed the spillway after transitioning from the PH\#3 area. During 2008, the proportion of fish that passed the spillway after transitioning from the powerhouse was about the same as in 2006, but less than what was observed in 2007 (table 47). This was likely the result of moving the TSW from bay 22 to bay 19, farther from the powerhouse, for the 2008 study. Having only one TSW in the southern portion of the spillway during the spring of 2009 may have resulted in more lateral movement within and between the powerhouse and spillway before fish passed. During 2009, the number of fish passing the spillway area after transitioning from the PH\#3 area increased for yearling Chinook salmon, steelhead, and sockeye salmon, but decreased for subyearling Chinook salmon compared to 2008 (table 48). We also observed that the proportion of fish passing the PH\#1 and PH\#2 area after moving from one of the adjoining powerhouse areas increased in 2009 compared to 2008. 
Table 43. Percentage of fish passing McNary Dam during day and night periods in 2008 based on a two-step Markov Chain analysis.

[Data represent all fish that first approached the powerhouse and include both day and night periods. Species: YCH, Yearling Chinook salmon; STH, juvenile steelhead; SCH, subyearling Chinook salmon; SOC, Sockeye salmon. Area of Passage: PH\#1, turbine units 1-5; PH\#2, turbine units 6-10; PH\#3, turbine units 11-14; Spillway, spill bays 1-22; Service Bay, equipment service bay on the south end of powerhouse; TSW, temporary spillway weir; ( $)$ denotes the TSW was not installed; Superscripts denote number of transitions used to calculate percentage: a, greater than 100; b , 50-100; c , 10 to 50; $(*)$, less than 10 , which was insufficient sample size to calculate percentage]

\begin{tabular}{|c|c|c|c|c|c|c|c|c|c|c|c|c|c|c|c|c|c|}
\hline $\begin{array}{c}\text { Area of } \\
\text { Passage: }\end{array}$ & \multicolumn{3}{|c|}{$\mathrm{PH} \# 1$} & \multicolumn{3}{|c|}{$\mathrm{PH} \# 2$} & \multicolumn{3}{|c|}{$\mathrm{PH} \# 3$} & \multicolumn{8}{|c|}{ Spillway } \\
\hline \multirow[b]{2}{*}{ Species } & $\begin{array}{l}\text { passing } \\
\text { PH\#1 } \\
\text { after } \\
\text { coming } \\
\text { from }\end{array}$ & $\begin{array}{l}\text { passing } \\
\text { PH\#1 } \\
\text { after } \\
\text { coming } \\
\text { from }\end{array}$ & $\begin{array}{l}\text { passing } \\
\text { PH\#1 } \\
\text { after } \\
\text { coming } \\
\text { from }\end{array}$ & $\begin{array}{l}\text { passing } \\
\mathrm{PH} 22 \\
\text { after } \\
\text { coming } \\
\text { from }\end{array}$ & $\begin{array}{l}\text { passing } \\
\text { PH\#2 } \\
\text { after } \\
\text { coming } \\
\text { from }\end{array}$ & $\begin{array}{l}\text { passing } \\
\text { PH\#2 } \\
\text { after } \\
\text { coming } \\
\text { from }\end{array}$ & $\begin{array}{l}\text { passing } \\
\text { PH\#3 } \\
\text { after } \\
\text { coming } \\
\text { from }\end{array}$ & $\begin{array}{l}\text { passing } \\
\text { PH\#3 } \\
\text { after } \\
\text { coming } \\
\text { from }\end{array}$ & $\begin{array}{l}\text { passing } \\
\text { PH\#3 } \\
\text { after } \\
\text { coming } \\
\text { from }\end{array}$ & $\begin{array}{l}\text { passir } \\
\text { from } F\end{array}$ & $\begin{array}{l}\text { spillw } \\
\text { H33 }\end{array}$ & after & ming & $\begin{array}{l}\text { passi } \\
\text { from } f\end{array}$ & $\begin{array}{l}\text { spillwa } \\
\text { ebay }\end{array}$ & $y$ after & oming \\
\hline & & & & & & & & & & $\frac{\text { TSW }}{\underline{20}}$ & $\frac{\text { TSW }}{\underline{19}}$ & Bays & $\frac{\text { TSW }}{\underline{4}}$ & $\frac{\text { TSW }}{\underline{20}}$ & $\frac{\text { TSW }}{\underline{19}}$ & Bays & $\frac{\text { TSW }}{\underline{4}}$ \\
\hline $\mathrm{YCH}$ & $19^{c}$ & $22^{\mathrm{b}}$ & $19^{\mathrm{b}}$ & $19^{\mathrm{a}}$ & $26^{\mathrm{b}}$ & $22^{\mathrm{b}}$ & $21^{\mathrm{a}}$ & $16^{\mathrm{b}}$ & $38^{\mathrm{c}}$ & $36^{\mathrm{a}}$ & $16^{\mathrm{a}}$ & $36^{\mathrm{a}}$ & 1 & NA & NA & NA & 1 \\
\hline STH & $8^{b}$ & $21^{\mathrm{a}}$ & $11^{\mathrm{a}}$ & $12^{\mathrm{a}}$ & $2^{\mathrm{b}}$ & $6^{\mathrm{a}}$ & $7^{\mathrm{a}}$ & $7^{\mathrm{a}}$ & $25^{\mathrm{b}}$ & $39^{\mathrm{a}}$ & $15^{\mathrm{a}}$ & $21^{\mathrm{a}}$ & 1 & NA & NA & NA & 1 \\
\hline $\mathrm{SCH}$ & $18^{\mathrm{a}}$ & $31^{\mathrm{a}}$ & $20^{\mathrm{a}}$ & $18^{\mathrm{a}}$ & $22^{\mathrm{a}}$ & $5^{\mathrm{b}}$ & $15^{\mathrm{a}}$ & $14^{\mathrm{b}}$ & $25^{\mathrm{c}}$ & $20^{\mathrm{a}}$ & $16^{\mathrm{a}}$ & $51^{\mathrm{a}}$ & 1 & NA & NA & NA & 1 \\
\hline SOC & $*$ & $40^{\mathrm{c}}$ & $*$ & $88^{\mathrm{c}}$ & $84^{\mathrm{c}}$ & $*$ & $*$ & $35^{\mathrm{c}}$ & $*$ & $*$ & $*$ & $*$ & 1 & NA & NA & NA & 1 \\
\hline
\end{tabular}


Table 44. Percentage of fish passing McNary Dam during day and night periods in 2009 based on a two-step Markov Chain analysis..

[Data represent all fish that first approached the powerhouse and include both day and night periods. Species: YCH, Yearling Chinook salmon; STH, juvenile steelhead; SCH, subyearling Chinook salmon; SOC, Sockeye salmon. Area of Passage: PH\#1, turbine units 1-5; PH\#2, turbine units 6-10; PH\#3, turbine units 11-14; Spillway, spill bays 1-22; Service Bay, equipment service bay on the south end of powerhouse; TSW, Temporary spillway weir; ( $)$ denotes the TSW was not installed; Superscripts denote number of transitions used to calculate percentage: a, greater than 100; b , 50-100; c , 10 to 50; $(*)$, less than 10 , which was insufficient sample size to calculate percentage]

\begin{tabular}{|c|c|c|c|c|c|c|c|c|c|c|c|c|c|c|c|c|c|}
\hline $\begin{array}{l}\text { Area of } \\
\text { Passage }\end{array}$ & \multicolumn{3}{|c|}{$\mathrm{PH} \# 1$} & \multicolumn{3}{|c|}{$\mathrm{PH} \# 2$} & \multicolumn{3}{|c|}{$\mathrm{PH} \# 3$} & \multicolumn{8}{|c|}{ Spillway } \\
\hline \multirow[b]{2}{*}{ Species } & $\begin{array}{l}\text { passing } \\
\text { PH\#1 } \\
\text { after } \\
\text { coming } \\
\text { from }\end{array}$ & $\begin{array}{l}\text { passing } \\
\text { PH\#1 } \\
\text { after } \\
\text { coming } \\
\text { from }\end{array}$ & $\begin{array}{l}\text { passing } \\
\text { PH\#1 } \\
\text { after } \\
\text { coming } \\
\text { from }\end{array}$ & $\begin{array}{l}\text { passing } \\
\text { PH\#2 } \\
\text { after } \\
\text { coming } \\
\text { from }\end{array}$ & $\begin{array}{l}\text { passing } \\
\text { PH\#2 } \\
\text { after } \\
\text { coming } \\
\text { from }\end{array}$ & $\begin{array}{l}\text { passing } \\
\text { PH\#2 } \\
\text { after } \\
\text { coming } \\
\text { from }\end{array}$ & $\begin{array}{l}\text { passing } \\
\text { PH\#3 } \\
\text { after } \\
\text { coming } \\
\text { from }\end{array}$ & $\begin{array}{l}\text { passing } \\
\text { PH\#3 } \\
\text { after } \\
\text { coming } \\
\text { from }\end{array}$ & $\begin{array}{l}\text { passing } \\
\text { PH\#3 } \\
\text { after } \\
\text { coming } \\
\text { from }\end{array}$ & $\begin{array}{l}\text { pass } \\
\text { comi }\end{array}$ & $\begin{array}{l}\text { spillw } \\
\text { from } F\end{array}$ & $\begin{array}{l}y \text { afte } \\
\text { H\#3 }\end{array}$ & & $\begin{array}{l}\text { pass } \\
\text { comi }\end{array}$ & $\begin{array}{l}\text { spillv } \\
\text { from }\end{array}$ & $\begin{array}{l}\text { y afte } \\
\text { rebay }\end{array}$ & \\
\hline & & & & & & & & & & $\frac{\text { TSW }}{\underline{20}}$ & $\frac{\text { TSW }}{\underline{19}}$ & Bays & $\frac{\text { TSW }}{\underline{4}}$ & $\frac{\frac{\text { TSW }}{\underline{20}}}{\underline{n}}$ & $\frac{\text { TSW }}{\underline{19}}$ & Bays & $\frac{\text { TSW }}{\underline{4}}$ \\
\hline $\mathrm{YCH}$ & $22^{\mathrm{a}}$ & $27^{\mathrm{a}}$ & $15^{\mathrm{a}}$ & $14^{\mathrm{a}}$ & $30^{\mathrm{a}}$ & $13^{\mathrm{a}}$ & $20^{\mathrm{a}}$ & $40^{\mathrm{a}}$ & $37^{\mathrm{c}}$ & $23^{\mathrm{a}}$ & 1 & $64^{\mathrm{a}}$ & $4^{\mathrm{a}}$ & NA & 1 & NA & NA \\
\hline STH & $11^{\mathrm{a}}$ & $11^{\mathrm{a}}$ & $10^{\mathrm{a}}$ & $6^{\mathrm{a}}$ & $18^{\mathrm{a}}$ & $7^{\mathrm{a}}$ & $6^{\mathrm{a}}$ & $14^{\mathrm{a}}$ & $4^{b}$ & $37^{\mathrm{a}}$ & 1 & $33^{\mathrm{a}}$ & $8^{a}$ & NA & 1 & NA & NA \\
\hline $\mathrm{SCH}$ & $14^{\mathrm{a}}$ & $27^{\mathrm{a}}$ & $12^{\mathrm{a}}$ & $9^{\mathrm{a}}$ & $16^{\mathrm{a}}$ & $11^{\mathrm{a}}$ & $21^{\mathrm{a}}$ & $44^{\mathrm{a}}$ & $31^{\mathrm{c}}$ & $34^{\mathrm{a}}$ & $9^{a}$ & $49^{\mathrm{a}}$ & 1 & NA & NA & NA & 1 \\
\hline SOC & * & $96^{\mathrm{a}}$ & $12^{\mathrm{a}}$ & $16^{\mathrm{a}}$ & $96^{\mathrm{a}}$ & $21^{\mathrm{a}}$ & $13^{\mathrm{a}}$ & $64^{\mathrm{a}}$ & $48^{\mathrm{c}}$ & $30^{\mathrm{a}}$ & 1 & $64^{\mathrm{a}}$ & $2^{\mathrm{a}}$ & NA & 1 & NA & NA \\
\hline
\end{tabular}


Table 45. Percentage of fish passing McNary Dam during day and night periods in 2006 based on a two-step Markov Chain analysis.

[Data represent all fish that first approached the spillway and include both day and night periods. Species: YCH, Yearling Chinook salmon; STH, juvenile steelhead; SCH, subyearling Chinook salmon; SOC, Sockeye salmon. Area of Passage: PH\#1, turbine units 1-5; PH\#2, turbine units 6-10; PH\#3, turbine units 11-14; Spillway, spill bays 1-22; Service Bay, equipment service bay on the south end of powerhouse; TSW, temporary spillway weir; ( () denotes the TSW was not installed; Superscripts denote number of transitions used to calculate percentage: a, greater than 100; b , 50-100; c , 10 to 50; $(*)$, less than 10, which was insufficient sample size to calculate percentage]

\begin{tabular}{|c|c|c|c|c|c|c|c|c|c|c|c|c|c|c|c|c|c|}
\hline $\begin{array}{c}\text { Area of } \\
\text { Passage: }\end{array}$ & \multicolumn{3}{|c|}{$\mathrm{PH} \# 1$} & \multicolumn{3}{|c|}{$\mathrm{PH} \# 2$} & \multicolumn{3}{|c|}{$\mathrm{PH} \# 3$} & \multicolumn{8}{|c|}{ Spillway } \\
\hline \multirow[b]{2}{*}{ Species } & $\begin{array}{l}\text { passing } \\
\text { PH\#1 } \\
\text { after } \\
\text { coming } \\
\text { from }\end{array}$ & $\begin{array}{l}\text { passing } \\
\mathrm{PH \# 1} \\
\text { after } \\
\text { coming } \\
\text { from }\end{array}$ & $\begin{array}{l}\text { passing } \\
\text { PH\#1 } \\
\text { after } \\
\text { coming } \\
\text { from }\end{array}$ & $\begin{array}{l}\text { passing } \\
\text { PH\#2 } \\
\text { after } \\
\text { coming } \\
\text { from }\end{array}$ & $\begin{array}{l}\text { passing } \\
\text { PH\#2 } \\
\text { after } \\
\text { coming } \\
\text { from }\end{array}$ & $\begin{array}{l}\text { passing } \\
\text { PH\#2 } \\
\text { after } \\
\text { coming } \\
\text { from }\end{array}$ & $\begin{array}{l}\text { passing } \\
\text { PH\#3 } \\
\text { after } \\
\text { coming } \\
\text { from }\end{array}$ & $\begin{array}{l}\text { passing } \\
\text { PH\#3 } \\
\text { after } \\
\text { coming } \\
\text { from }\end{array}$ & $\begin{array}{l}\text { passing } \\
\text { PH\#3 } \\
\text { after } \\
\text { coming } \\
\text { from }\end{array}$ & $\begin{array}{l}\text { passi } \\
\text { comir }\end{array}$ & $\begin{array}{l}\text { spillw } \\
\text { from } F\end{array}$ & $\begin{array}{l}y \text { after } \\
\text { H\#3 }\end{array}$ & & $\begin{array}{l}\text { passi } \\
\text { comir }\end{array}$ & $\begin{array}{l}9 \text { spillw } \\
\text { from } f\end{array}$ & $\begin{array}{l}\text { y after } \\
\text { rebay }\end{array}$ & \\
\hline & & & & & & & & & & $\frac{\text { TSW }}{\underline{22}}$ & $\frac{\text { TSW }}{\underline{20}}$ & Bays & $\frac{\text { TSW }}{\underline{4}}$ & $\frac{\text { TSW }}{\underline{22}}$ & $\frac{\text { TSW }}{\underline{20}}$ & Bays & $\frac{\text { TSW }}{\underline{4}}$ \\
\hline $\mathrm{YCH}$ & $*$ & NA & $*$ & $*$ & NA & $31^{\mathrm{c}}$ & $20^{c}$ & NA & $0^{\mathrm{c}}$ & 1 & 1 & $*$ & 1 & 1 & 1 & $96^{\mathrm{a}}$ & 1 \\
\hline STH & $0^{\mathrm{c}}$ & NA & $21^{\mathrm{c}}$ & $5^{c}$ & NA & $5^{\mathrm{b}}$ & $3^{b}$ & NA & $11^{\mathrm{b}}$ & 1 & 1 & $68^{c}$ & 1 & 1 & 1 & $61^{\mathrm{a}}$ & 1 \\
\hline $\mathrm{SCH}$ & $20^{\mathrm{c}}$ & NA & $20^{\mathrm{c}}$ & $6^{\mathrm{c}}$ & NA & $6^{\mathrm{b}}$ & $3^{c}$ & NA & $3^{c}$ & 1 & 1 & $94^{\mathrm{c}}$ & 1 & 1 & 1 & $46^{\mathrm{b}}$ & 1 \\
\hline SOC & $*$ & NA & $*$ & $*$ & NA & $*$ & $*$ & NA & $*$ & 1 & 1 & $*$ & 1 & 1 & 1 & $*$ & 1 \\
\hline
\end{tabular}


Table 46. Percentage of fish passing McNary Dam during day and night periods in 2007 based on a two-step Markov Chain analysis.

[Data represent all fish that first approached the spillway and include both day and night periods. Species: YCH, Yearling Chinook salmon; STH, juvenile steelhead; SCH, subyearling Chinook salmon; SOC, Sockeye salmon. Area of Passage: PH\#1, turbine units 1-5; PH\#2, turbine units 6-10; PH\#3, turbine units 11-14; Spillway, spill bays 1-22; Service Bay, equipment service bay on the south end of powerhouse; TSW, temporary spillway weir; ( () denotes the TSW was not installed; Superscripts denote number of transitions used to calculate percentage: a, greater than 100; b , 50-100; c, 10 to 50; $(*)$, less than 10 , which was insufficient sample size to calculate percentage]

\begin{tabular}{|c|c|c|c|c|c|c|c|c|c|c|c|c|c|c|c|c|c|}
\hline $\begin{array}{c}\text { Area of } \\
\text { Passage }\end{array}$ & \multicolumn{3}{|c|}{$\mathrm{PH} \# 1$} & \multicolumn{3}{|c|}{$\mathrm{PH} \# 2$} & \multicolumn{3}{|c|}{$\mathrm{PH} \# 3$} & \multicolumn{8}{|c|}{ Spillway } \\
\hline \multirow[b]{2}{*}{ Species } & $\begin{array}{l}\text { passing } \\
\text { PH\#1 } \\
\text { after } \\
\text { coming } \\
\text { from }\end{array}$ & $\begin{array}{l}\text { passing } \\
\text { PH\#1 } \\
\text { after } \\
\text { coming } \\
\text { from }\end{array}$ & $\begin{array}{l}\text { passing } \\
\text { PH\#1 } \\
\text { after } \\
\text { coming } \\
\text { from }\end{array}$ & $\begin{array}{l}\text { passing } \\
\text { PH\#2 } \\
\text { after } \\
\text { coming } \\
\text { from }\end{array}$ & $\begin{array}{l}\text { passing } \\
\text { PH\#2 } \\
\text { after } \\
\text { coming } \\
\text { from }\end{array}$ & $\begin{array}{l}\text { passing } \\
\text { PH\#2 } \\
\text { after } \\
\text { coming } \\
\text { from }\end{array}$ & $\begin{array}{l}\text { passing } \\
\mathrm{PH \# 3} \\
\text { after } \\
\text { coming } \\
\text { from }\end{array}$ & $\begin{array}{l}\text { passing } \\
\text { PH\#3 } \\
\text { after } \\
\text { coming } \\
\text { from }\end{array}$ & $\begin{array}{l}\text { passing } \\
\text { PH\#3 } \\
\text { after } \\
\text { coming } \\
\text { from }\end{array}$ & $\begin{array}{l}\text { pass } \\
\text { comi }\end{array}$ & $\begin{array}{l}\text { spillw } \\
\text { from } F\end{array}$ & $\begin{array}{l}\text { y afte } \\
\text { H\#3 }\end{array}$ & & $\begin{array}{l}\text { passir } \\
\text { comin }\end{array}$ & $\begin{array}{l}\text { spillu } \\
\text { from }\end{array}$ & $\begin{array}{l}\text { yy after } \\
\text { rebay }\end{array}$ & \\
\hline & & & & & & & & & & $\frac{\frac{\text { TSW }}{\underline{22}}}{\underline{n}}$ & $\frac{\text { TSW }}{\underline{20}}$ & Bays & $\frac{\mathrm{TSW}}{\underline{4}}$ & $\frac{\text { TSW }}{\underline{22}}$ & $\frac{\text { TSW }}{\underline{20}}$ & Bays & $\frac{\text { TSW }}{\underline{4}}$ \\
\hline $\mathrm{YCH}$ & * & NA & $0^{\mathrm{c}}$ & $*$ & NA & $40^{\mathrm{c}}$ & $8^{c}$ & NA & $25^{\mathrm{c}}$ & $72^{c}$ & $6^{\mathrm{c}}$ & $11^{\mathrm{c}}$ & 1 & $13^{\mathrm{a}}$ & $17^{\mathrm{a}}$ & $58^{\mathrm{a}}$ & 1 \\
\hline STH & $15^{\mathrm{c}}$ & NA & $4^{\mathrm{a}}$ & $5^{b}$ & NA & $5^{\mathrm{a}}$ & $5^{\mathrm{b}}$ & NA & $2^{\mathrm{a}}$ & $60^{\mathrm{b}}$ & $11^{\mathrm{b}}$ & $7^{\mathrm{b}}$ & 1 & $18^{\mathrm{a}}$ & $28^{\mathrm{a}}$ & $27^{\mathrm{a}}$ & 1 \\
\hline $\mathrm{SCH}$ & $*$ & NA & $19^{c}$ & $10^{\mathrm{c}}$ & NA & $13^{\mathrm{c}}$ & $18^{\mathrm{c}}$ & NA & $15^{\mathrm{c}}$ & $53^{c}$ & $7^{\mathrm{c}}$ & $33^{c}$ & 1 & $22^{\mathrm{a}}$ & $27^{\mathrm{a}}$ & $31^{\mathrm{a}}$ & 1 \\
\hline SOC & $*$ & NA & $*$ & $*$ & NA & $*$ & $*$ & NA & $68^{c}$ & $*$ & $*$ & $*$ & 1 & $17^{\mathrm{c}}$ & $20^{\mathrm{c}}$ & $9^{c}$ & 1 \\
\hline
\end{tabular}


Table 47. Percentage of fish passing McNary Dam during day and night periods in 2008 based on a two-step Markov Chain analysis.

[Data represent all fish that first approached the spillway and includes both day and night periods. Species: YCH, Yearling Chinook salmon; STH, juvenile steelhead; SCH, subyearling Chinook salmon; SOC, Sockeye salmon. Area of Passage: PH\#1, turbine units 1-5; PH\#2, turbine units 6-10; PH\#3, turbine units 11-14; Spillway, spill bays 1-22; Service Bay, equipment service bay on the south end of powerhouse; TSW, temporary spillway weir; ( () denotes the TSW was not installed; Superscripts denote number of transitions used to calculate percentage: a, greater than 100; b , 50-100; c, 10 to 50; $(*)$, less than 10 , which was insufficient sample size to calculate percentage]

\begin{tabular}{|c|c|c|c|c|c|c|c|c|c|c|c|c|c|c|c|c|c|}
\hline $\begin{array}{c}\text { Area of } \\
\text { Passage }\end{array}$ & \multicolumn{3}{|c|}{$\mathrm{PH} \# 1$} & \multicolumn{3}{|c|}{$\mathrm{PH} \# 2$} & \multicolumn{3}{|c|}{$\mathrm{PH} \# 3$} & \multicolumn{8}{|c|}{ Spillway } \\
\hline \multirow[b]{2}{*}{ Species } & $\begin{array}{l}\text { passing } \\
\text { PH\#1 } \\
\text { after } \\
\text { coming } \\
\text { from }\end{array}$ & $\begin{array}{l}\text { passing } \\
\text { PH\#1 } \\
\text { after } \\
\text { coming } \\
\text { from }\end{array}$ & $\begin{array}{l}\text { passing } \\
\text { PH\#1 } \\
\text { after } \\
\text { coming } \\
\text { from }\end{array}$ & $\begin{array}{l}\text { passing } \\
\text { PH\#2 } \\
\text { after } \\
\text { coming } \\
\text { from }\end{array}$ & $\begin{array}{l}\text { passing } \\
\text { PH\#2 } \\
\text { after } \\
\text { coming } \\
\text { from }\end{array}$ & $\begin{array}{l}\text { passing } \\
\text { PH\#2 } \\
\text { after } \\
\text { coming } \\
\text { from }\end{array}$ & $\begin{array}{l}\text { passing } \\
\mathrm{PH \# 3} \\
\text { after } \\
\text { coming } \\
\text { from }\end{array}$ & $\begin{array}{l}\text { passing } \\
\text { PH\#3 } \\
\text { after } \\
\text { coming } \\
\text { from }\end{array}$ & $\begin{array}{l}\text { passing } \\
\text { PH\#3 } \\
\text { after } \\
\text { coming } \\
\text { from }\end{array}$ & $\begin{array}{l}\text { passi } \\
\text { comir }\end{array}$ & $\begin{array}{l}\text { spillw } \\
\text { from } F\end{array}$ & $\begin{array}{l}y \text { afte } \\
\text { H\#3 }\end{array}$ & & $\begin{array}{l}\text { passir } \\
\text { comin }\end{array}$ & $\begin{array}{l}\text { spilly } \\
\text { from } f\end{array}$ & $\begin{array}{l}\text { y after } \\
\text { rebay }\end{array}$ & \\
\hline & & & & & & & & & & $\frac{\text { TSW }}{\underline{20}}$ & $\frac{\text { TSW }}{\underline{19}}$ & Bays & $\frac{\mathrm{TSW}}{\underline{4}}$ & $\frac{\text { TSW }}{\underline{20}}$ & $\frac{\text { TSW }}{\underline{19}}$ & Bays & $\frac{\text { TSW }}{\underline{4}}$ \\
\hline $\mathrm{YCH}$ & $*$ & NA & $13^{c}$ & $23^{c}$ & NA & $9^{c}$ & $28^{c}$ & NA & $38^{\mathrm{c}}$ & $23^{c}$ & $15^{\mathrm{c}}$ & $23^{\mathrm{c}}$ & 1 & $13^{\mathrm{a}}$ & $30^{\mathrm{a}}$ & $32^{\mathrm{a}}$ & 1 \\
\hline STH & $20^{\mathrm{c}}$ & NA & $5^{c}$ & $0^{\mathrm{c}}$ & NA & $2^{\mathrm{b}}$ & $5^{c}$ & NA & $13^{\mathrm{b}}$ & $29^{\mathrm{b}}$ & $18^{\mathrm{b}}$ & $23^{b}$ & 1 & $10^{\mathrm{a}}$ & $21^{\mathrm{a}}$ & $22^{\mathrm{a}}$ & 1 \\
\hline $\mathrm{SCH}$ & $5^{c}$ & NA & $0^{\mathrm{c}}$ & $6^{\mathrm{c}}$ & NA & $0^{\mathrm{c}}$ & $14^{\mathrm{c}}$ & NA & $27^{\mathrm{c}}$ & $16^{\mathrm{c}}$ & $16^{\mathrm{c}}$ & $53^{c}$ & 1 & $18^{\mathrm{a}}$ & $21^{\mathrm{a}}$ & $32^{\mathrm{a}}$ & 1 \\
\hline SOC & $*$ & NA & $*$ & $*$ & NA & * & $*$ & NA & $*$ & $*$ & $*$ & $*$ & 1 & $*$ & $*$ & $*$ & 1 \\
\hline
\end{tabular}


Table 48. Percentage of fish passing McNary Dam during day and night periods in 2009 based on a two-step Markov Chain analysis.

[Data represent all fish that first approached the spillway and includes both day and night periods. Species: YCH, Yearling Chinook salmon; STH, juvenile steelhead; SCH, subyearling Chinook salmon; SOC, Sockeye salmon. Area of Passage: PH\#1, turbine units 1-5; PH\#2, turbine units 6-10; PH\#3, turbine units 11-14; Spillway, spill bays 1-22; Service Bay, equipment service bay on the south end of powerhouse; TSW, temporary spillway weir; ( () denotes the TSW was not installed; Superscripts denote number of transitions used to calculate percentage: a, greater than 100; b , 50-100; c, 10 to 50; $(*)$, less than 10 , which was insufficient sample size to calculate percentage]

\begin{tabular}{|c|c|c|c|c|c|c|c|c|c|c|c|c|c|c|c|c|c|}
\hline $\begin{array}{c}\text { Area of } \\
\text { Passage: }\end{array}$ & \multicolumn{3}{|c|}{$\mathrm{PH} \# 1$} & \multicolumn{3}{|c|}{$\mathrm{PH} \# 2$} & \multicolumn{3}{|c|}{$\mathrm{PH} \# 3$} & \multicolumn{8}{|c|}{ Spillway } \\
\hline \multirow[b]{2}{*}{ Species } & $\begin{array}{l}\text { passing } \\
\text { PH\#1 } \\
\text { after } \\
\text { coming } \\
\text { from }\end{array}$ & $\begin{array}{l}\text { passing } \\
\mathrm{PH \# 1} \\
\text { after } \\
\text { coming } \\
\text { from }\end{array}$ & $\begin{array}{l}\text { passing } \\
\text { PH\#1 } \\
\text { after } \\
\text { coming } \\
\text { from }\end{array}$ & $\begin{array}{l}\text { passing } \\
\text { PH\#2 } \\
\text { after } \\
\text { coming } \\
\text { from }\end{array}$ & $\begin{array}{l}\text { passing } \\
\text { PH\#2 } \\
\text { after } \\
\text { coming } \\
\text { from }\end{array}$ & $\begin{array}{l}\text { passing } \\
\text { PH\#2 } \\
\text { after } \\
\text { coming } \\
\text { from }\end{array}$ & $\begin{array}{l}\text { passing } \\
\text { PH\#3 } \\
\text { after } \\
\text { coming } \\
\text { from }\end{array}$ & $\begin{array}{l}\text { passing } \\
\text { PH\#3 } \\
\text { after } \\
\text { coming } \\
\text { from }\end{array}$ & $\begin{array}{l}\text { passing } \\
\text { PH\#3 } \\
\text { after } \\
\text { coming } \\
\text { from }\end{array}$ & $\begin{array}{l}\text { passi } \\
\text { comir }\end{array}$ & $\begin{array}{l}\text { spillw } \\
\text { from } F\end{array}$ & $\begin{array}{l}y \text { after } \\
-\# 33\end{array}$ & & $\begin{array}{l}\text { passi } \\
\text { comir }\end{array}$ & $\begin{array}{l}9 \text { spillw } \\
\text { from } f\end{array}$ & $\begin{array}{l}\text { y after } \\
\text { rebay }\end{array}$ & \\
\hline & & & & & & & & & & $\frac{\text { TSW }}{\underline{20}}$ & $\frac{\text { TSW }}{\underline{19}}$ & Bays & $\frac{\text { TSW }}{\underline{4}}$ & $\frac{\text { TSW }}{\underline{20}}$ & $\frac{\text { TSW }}{\underline{19}}$ & Bays & $\frac{\text { TSW }}{\underline{4}}$ \\
\hline $\mathrm{YCH}$ & $*$ & NA & $30^{\mathrm{c}}$ & $9^{c}$ & NA & $32^{\mathrm{c}}$ & $39^{c}$ & NA & $34^{\mathrm{b}}$ & $31^{\mathrm{c}}$ & 1 & $56^{\mathrm{c}}$ & $0^{\mathrm{c}}$ & $12^{\mathrm{a}}$ & 1 & $65^{\mathrm{a}}$ & $8^{\mathrm{a}}$ \\
\hline STH & $7^{\mathrm{c}}$ & NA & $9^{b}$ & $7^{\mathrm{b}}$ & NA & $7^{\mathrm{a}}$ & $13^{b}$ & NA & $16^{\mathrm{a}}$ & $39^{b}$ & 1 & $28^{\mathrm{b}}$ & $5^{b}$ & $16^{\mathrm{a}}$ & 1 & $43^{\mathrm{a}}$ & $14^{\mathrm{a}}$ \\
\hline $\mathrm{SCH}$ & $0^{\mathrm{c}}$ & NA & $9^{c}$ & $10^{\mathrm{c}}$ & NA & $11^{\mathrm{c}}$ & $17^{\mathrm{c}}$ & NA & $38^{\mathrm{c}}$ & $14^{\mathrm{c}}$ & $24^{\mathrm{c}}$ & $52^{\mathrm{c}}$ & 1 & $11^{\mathrm{a}}$ & $21^{\mathrm{a}}$ & $60^{\mathrm{a}}$ & 1 \\
\hline $\mathrm{SOC}$ & $*$ & NA & $*$ & $*$ & NA & $25^{\mathrm{c}}$ & $0^{\mathrm{c}}$ & NA & $87^{\mathrm{c}}$ & $33^{c}$ & 1 & $67^{\mathrm{c}}$ & $0^{\mathrm{c}}$ & $24^{\mathrm{a}}$ & 1 & $61^{\mathrm{a}}$ & $12^{\mathrm{a}}$ \\
\hline
\end{tabular}


We conducted further analysis using the two-step methods to investigate how passage proportions for fish that first approached the spillway might be influenced if the fish passed during the day compared to the night. The overall trends in passage proportions were similar to those observed for fish regardless of the time of day they passed. The results are presented in appendix E.

\section{Evaluation of a Virtual Fish Collector}

Results of the simulation of a virtual fish collector (VFC) indicated that a VFC would have a relatively localized effect on passage probabilities at McNary Dam, especially during years when TSWs also were installed. The results of the simulation are presented in tables 49-52 for the study years 20062009 , respectively. For each study year, the percent passage of 1,000 fish was simulated with a VFC in the PH\#2 area that had an assumed efficiency of 0, 30, and 50 percent. During 2006, with no TSWs and a VFC efficiency of 0 percent, 0.48 of the 1000 yearling Chinook salmon and 0.28 of the 1000 subyearling Chinook salmon would pass through the spill bays. Between 0.11 and 0.32 of the fish (depending on species) would pass through the powerhouse (through either the JBS or turbine intakes) in one of the three areas in the powerhouse (table 49). If a VFC was installed in the PH\#2 area and had an efficiency of 30 percent, 0.23 of the yearling Chinook salmon and 0.39 of the subyearling Chinook salmon would pass through the VFC. Under this scenario, passage in the spillway would be reduced by 0.05-0.08 and passage through the powerhouse in the PH\#2 area would be reduced by $0.9-0.14$, assuming fish that entered the VFC would be routed through the dam through a route other than the turbine intakes. If the VFC had an efficiency of 50 percent, passage through the powerhouse in the PH\#2 area would be reduced by $0.14-0.20$.

The effect of the VFC on passage probabilities during 2007 was similar to 2006 (table 50). However, the presence of the TSWs in the spillway reduced the number of fish available to enter and pass through the VFC, thereby diminishing the potential benefit of the VFC. During 2007, with TSWs in the spillway and a VFC efficiency of 30 percent, passage through the spillway was reduced by $0.01-$ 0.03 compared to a VFC with 0 percent efficiency and passage through the powerhouse in the $\mathrm{PH \# 2}$ area was reduced by $0.10-0.12$. If the VFC had an efficiency of 50 percent, passage through the powerhouse in the PH\#2 area would be reduced by 0.16-0.18. Similar trends were observed when the VFC was simulated in the PH\#2 area during 2008 (table 51) and 2009 (table 52).

There were two instances when the results of the simulation using the 2006 data indicated that more than 30 percent or 50 percent of the fish entered the VFC. These outcomes were a result of the way fish were distributed across the forebay of the dam. When the simulations were initiated, the number of fish entering each of the four areas upstream of the dam was based on the actual distribution of fish observed in 2006, not based on an arbitrary assignment of fish. For example, the outcome of the simulations would have been different if we assigned 250 fish as entering each of the four areas upstream of the dam. In 2006, the majority of the fish first approached the powerhouse. As a result, a higher proportion of the 1,000 simulated fish were assigned to first approach the powerhouse. Because more fish transitioned across the face of the powerhouse, the probability of having more than a 30 percent or 50 percent chance of passing through the VFC increased. Each time fish made the transition passed the VFC, the probability of passing was similar to that of the probability of flipping a coin and having it be heads or tails. If you flip a coin 10 times, there is a chance that you will get 6 heads and 4 tails even though the probability of getting heads or tails is 50 percent. 
Table 49. Simulated passage percentage of 1,000 fish at McNary Dam during day and night periods in 2006 based on a one-step Markov Chain analysis.

[Virtual fish collector (VFC) is located in PH \#2 area of passage. Maximum VFC efficiency set at 0, 30and 50 percent. Data represent proportions of all fish regardless of where they first approached the dam and include both day and night periods Species: $\mathrm{YCH}$, Yearling Chinook salmon; $\mathrm{SCH}$, subyearling Chinook salmon; Area of Passage: $\mathrm{PH} \# 1$, turbine units 1-5; PH\#2, turbine units 6-10; PH\#3, turbine units 11-14; Spillway, spill bays 1-22; TSW, temporary spillway weir; VFC, virtual modeled fish collector in PH \#2; ( ) denotes the TSW was not installed at this time]

\begin{tabular}{|c|c|c|c|c|c|c|c|c|}
\hline \multicolumn{9}{|c|}{ Area of Passage - VFC Maximum Efficiency $=0$ percent } \\
\hline \multirow[b]{2}{*}{ Species } & \multirow[t]{2}{*}{$\mathrm{PH} \# 1$} & \multirow[t]{2}{*}{$\mathrm{PH} \# 2$} & \multirow[t]{2}{*}{ VFC } & \multirow[t]{2}{*}{$\mathrm{PH} \# 3$} & \multicolumn{4}{|c|}{ Spillway } \\
\hline & & & & & TSW 22 & TSW 20 & Bays & TSW 4 \\
\hline $\mathrm{YCH}$ & 14 & 22 & 0 & 16 & 1 & 1 & 48 & 1 \\
\hline $\mathrm{SCH}$ & 32 & 29 & 0 & 11 & 1 & 1 & 28 & 1 \\
\hline
\end{tabular}

\begin{tabular}{|c|c|c|c|c|c|c|c|c|}
\hline \multicolumn{9}{|c|}{ Area of Passage - VFC Maximum Efficiency $=30$ percent } \\
\hline \multirow[b]{2}{*}{ Species } & \multirow[t]{2}{*}{$\mathrm{PH} \# 1$} & \multirow[t]{2}{*}{$\mathrm{PH} \# 2$} & \multirow[t]{2}{*}{ VFC } & \multirow[t]{2}{*}{$\mathrm{PH} \# 3$} & \multicolumn{4}{|c|}{ Spillway } \\
\hline & & & & & $\underline{\text { TSW } 22}$ & $\underline{\text { TSW } 20}$ & $\underline{\text { Bays }}$ & TSW 4 \\
\hline $\mathrm{YCH}$ & 10 & 13 & 23 & 11 & 1 & 1 & 43 & 1 \\
\hline $\mathrm{SCH}$ & 19 & 15 & 39 & 7 & 1 & 1 & 20 & 1 \\
\hline
\end{tabular}

\begin{tabular}{|c|c|c|c|c|c|c|c|c|}
\hline \multicolumn{9}{|c|}{ Area of Passage - VFC Maximum Efficiency $=50$ percent } \\
\hline \multirow[b]{2}{*}{ Species } & PH \#1 & $\mathrm{PH} \# 2$ & VFC & $\mathrm{PH} \# 3$ & \multicolumn{4}{|c|}{ Spillway } \\
\hline & & & & & TSW 22 & TSW 20 & Bays & TSW 4 \\
\hline $\mathrm{YCH}$ & 8 & 8 & 33 & 8 & 1 & 1 & 43 & 1 \\
\hline $\mathrm{SCH}$ & 13 & 9 & 56 & 5 & 1 & 1 & 17 & 1 \\
\hline
\end{tabular}


Table 50. Simulated passage percentage of 1,000 fish at McNary Dam during day and night periods in 2007 based on a one-step Markov Chain analysis.

[Virtual fish collector (VFC) is located in PH \#2 area of passage. Maximum VFC efficiency set at 0,30, and 50 percent. Data represent proportions of all fish regardless of where they first approached the dam and include both day and night periods. Species: YCH, Yearling Chinook salmon; SCH, subyearling Chinook salmon; Area of Passage: PH\#1, turbine units 1-5; PH\#2, turbine units 6-10; PH\#3, turbine units 11-14; Spillway, spill bays 1-22; TSW, temporary spillway weir; VFC, virtual modeled fish collector in PH \#2; ( ) denotes the TSW was not installed at this time]

\begin{tabular}{|c|c|c|c|c|c|c|c|c|}
\hline \multirow[b]{3}{*}{ Species } & \multicolumn{7}{|c|}{ Area of Passage - VFC Maximum Efficiency $=0$ percent } & \\
\hline & \multirow[t]{2}{*}{ PH \#1 } & \multirow[t]{2}{*}{$\mathrm{PH} \# 2$} & \multirow[t]{2}{*}{ VFC } & \multirow[t]{2}{*}{$\mathrm{PH} \# 3$} & \multicolumn{4}{|c|}{ Spillway } \\
\hline & & & & & TSW 20 & TSW 19 & Bays & TSW 4 \\
\hline $\mathrm{YCH}$ & 15 & 29 & 0 & 11 & 18 & 7 & 20 & 1 \\
\hline $\mathrm{SCH}$ & 25 & 26 & 0 & 8 & 20 & 9 & 12 & 1 \\
\hline
\end{tabular}

\begin{tabular}{|c|c|c|c|c|c|c|c|c|}
\hline \multicolumn{9}{|c|}{ Area of Passage - VFC Maximum Efficiency $=30$ percent } \\
\hline \multirow[b]{2}{*}{ Species } & \multirow[t]{2}{*}{$\mathrm{PH} \# 1$} & \multirow[t]{2}{*}{$\mathrm{PH} \# 2$} & \multirow[t]{2}{*}{ VFC } & \multirow[t]{2}{*}{$\mathrm{PH} \# 3$} & \multicolumn{4}{|c|}{ Spillway } \\
\hline & & & & & TSW 20 & $\underline{\text { TSW } 19}$ & Bays & TSW 4 \\
\hline $\mathrm{YCH}$ & 10 & 17 & 23 & 8 & 16 & 6 & 20 & 1 \\
\hline $\mathrm{SCH}$ & 17 & 16 & 26 & 6 & 17 & 8 & 10 & 1 \\
\hline
\end{tabular}

\begin{tabular}{|c|c|c|c|c|c|c|c|c|}
\hline \multicolumn{9}{|c|}{ Area of Passage - VFC Maximum Efficiency $=50$ percent } \\
\hline \multirow[b]{2}{*}{ Species } & \multirow[t]{2}{*}{$\mathrm{PH} \# 1$} & \multirow[t]{2}{*}{$\mathrm{PH} \# 2$} & \multirow[t]{2}{*}{ VFC } & \multirow[t]{2}{*}{$\mathrm{PH} \# 3$} & \multicolumn{4}{|c|}{ Spillway } \\
\hline & & & & & $\underline{\text { TSW } 20}$ & $\underline{\text { TSW } 19}$ & $\underline{\text { Bays }}$ & $\underline{\text { TSW } 4}$ \\
\hline $\mathrm{YCH}$ & 8 & 11 & 35 & 7 & 14 & 6 & 19 & 1 \\
\hline $\mathrm{SCH}$ & 13 & 10 & 39 & 4 & 15 & 8 & 11 & 1 \\
\hline
\end{tabular}


Table 51. Simulated passage percentage of 1000 fish at McNary Dam during day and night periods in 2008 based on a one-step Markov Chain analysis.

[Virtual fish collector (VFC) is located in PH \#2 area of passage. Maximum VFC efficiency set at 0, 30, and 50 percent. Data represent proportions of all fish regardless of where they first approached the dam and include both day and night periods. Species: YCH, Yearling Chinook salmon; SCH, subyearling Chinook salmon; Area of Passage: PH\#1, turbine units 1-5; PH\#2, turbine units 6-10; PH\#3, turbine units 11-14; Spillway, spill bays 1-22; TSW, temporary spillway weir; VFC, virtual modeled fish collector in PH \#2; ( ) denotes the TSW was not installed at this time]

\begin{tabular}{|c|c|c|c|c|c|c|c|c|}
\hline \multirow[b]{3}{*}{ Species } & \multicolumn{7}{|c|}{ Area of Passage - VFC Maximum Efficiency $=0$ percent } & \\
\hline & \multirow[t]{2}{*}{$\mathrm{PH} \# 1$} & \multirow[t]{2}{*}{$\mathrm{PH} \# 2$} & \multirow[t]{2}{*}{ VFC } & \multirow[t]{2}{*}{$\mathrm{PH} \# 3$} & \multicolumn{4}{|c|}{ Spillway } \\
\hline & & & & & TSW 20 & TSW 19 & Bays & TSW 4 \\
\hline $\mathrm{YCH}$ & 13 & 17 & 0 & 16 & 16 & 16 & 22 & 1 \\
\hline $\mathrm{SCH}$ & 26 & 15 & 0 & 11 & 12 & 11 & 25 & 1 \\
\hline
\end{tabular}

\begin{tabular}{|c|c|c|c|c|c|c|c|c|}
\hline \multicolumn{9}{|c|}{ Area of Passage - VFC Maximum Efficiency $=30$ percent } \\
\hline \multirow[b]{2}{*}{ Species } & \multirow[t]{2}{*}{$\mathrm{PH} \# 1$} & \multirow[t]{2}{*}{$\mathrm{PH} \# 2$} & \multirow[t]{2}{*}{ VFC } & \multirow[t]{2}{*}{$\mathrm{PH} \# 3$} & \multicolumn{4}{|c|}{ Spillway } \\
\hline & & & & & TSW 20 & $\underline{\text { TSW } 19}$ & Bays & TSW 4 \\
\hline $\mathrm{YCH}$ & 9 & 10 & 21 & 11 & 13 & 15 & 21 & 1 \\
\hline $\mathrm{SCH}$ & 19 & 9 & 26 & 7 & 10 & 9 & 20 & 1 \\
\hline
\end{tabular}

\begin{tabular}{|c|c|c|c|c|c|c|c|c|}
\hline \multicolumn{9}{|c|}{ Area of Passage - VFC Maximum Efficiency $=50$ percent } \\
\hline \multirow[b]{2}{*}{ Species } & PH \#1 & $\mathrm{PH} \# 2$ & VFC & $\mathrm{PH} \# 3$ & \multicolumn{4}{|c|}{ Spillway } \\
\hline & & & & & TSW 20 & $\underline{\text { TSW } 19}$ & Bays & TSW 4 \\
\hline $\mathrm{YCH}$ & 7 & 7 & 32 & 9 & 12 & 15 & 18 & 1 \\
\hline $\mathrm{SCH}$ & 16 & 6 & 39 & 5 & 10 & 8 & 16 & 1 \\
\hline
\end{tabular}


Table 52. Simulated passage percentage of 1,000 fish at McNary Dam during day and night periods in 2009 based on a one-step Markov Chain analysis.

[Virtual fish collector (VFC) is located in PH \#2 area of passage. Maximum VFC efficiency set at 0, 30, and 50 percent. Data represent proportions of all fish regardless of where they first approached the dam and include both day and night periods. Species: YCH, Yearling Chinook salmon; SCH, subyearling Chinook salmon; Area of Passage: PH\#1, turbine units 1-5; PH\#2, turbine units 6-10; PH\#3, turbine units 11-14; Spillway, spill bays 1-22; TSW, temporary spillway weir; VFC, virtual modeled fish collector in PH \#2; ( ) denotes the TSW was not installed at this time]

\begin{tabular}{|c|c|c|c|c|c|c|c|c|}
\hline \multirow[b]{3}{*}{ Species } & \multicolumn{7}{|c|}{ Area of Passage - VFC Maximum Efficiency $=0$ percent } & \multirow[b]{3}{*}{ TSW 4} \\
\hline & \multirow[t]{2}{*}{$\mathrm{PH} \# 1$} & \multirow[t]{2}{*}{$\mathrm{PH} \# 2$} & \multirow[t]{2}{*}{ VFC } & \multirow[t]{2}{*}{$\mathrm{PH} \# 3$} & \multicolumn{3}{|c|}{ Spillway } & \\
\hline & & & & & $\underline{\text { TSW } 20}$ & $\underline{\text { TSW } 19}$ & Bays & \\
\hline $\mathrm{YCH}$ & 15 & 16 & 0 & 19 & 9 & 1 & 37 & 4 \\
\hline $\mathrm{SCH}$ & 10 & 9 & 0 & 21 & 13 & 11 & 36 & 1 \\
\hline
\end{tabular}

\begin{tabular}{|c|c|c|c|c|c|c|c|c|}
\hline \multicolumn{9}{|c|}{ Area of Passage - VFC Maximum Efficiency $=30$ percent } \\
\hline \multirow[b]{2}{*}{ Species } & \multirow[t]{2}{*}{ PH \#1 } & \multirow[t]{2}{*}{ PH \#2 } & \multirow[t]{2}{*}{ VFC } & \multirow[t]{2}{*}{$\mathrm{PH} \# 3$} & \multicolumn{4}{|c|}{ Spillway } \\
\hline & & & & & TSW 20 & $\underline{\text { TSW } 19}$ & Bays & TSW 4 \\
\hline $\mathrm{YCH}$ & 9 & 9 & 23 & 13 & 8 & 1 & 34 & 4 \\
\hline $\mathrm{SCH}$ & 7 & 5 & 19 & 14 & 11 & 10 & 34 & 1 \\
\hline
\end{tabular}

\begin{tabular}{|c|c|c|c|c|c|c|c|c|}
\hline \multicolumn{9}{|c|}{ Area of Passage - VFC Maximum Efficiency $=50$ percent } \\
\hline \multirow[b]{2}{*}{ Species } & PH \#1 & PH \#2 & VFC & $\mathrm{PH} \# 3$ & \multicolumn{4}{|c|}{ Spillway } \\
\hline & & & & & TSW 20 & $\underline{\text { TSW } 19}$ & Bays & TSW 4 \\
\hline $\mathrm{YCH}$ & 7 & 6 & 33 & 10 & 8 & 1 & 33 & 3 \\
\hline $\mathrm{SCH}$ & 5 & 3 & 29 & 11 & 10 & 10 & 32 & 1 \\
\hline
\end{tabular}




\section{Discussion}

Before conducting the Markov chain analysis there had been no established method for quantifying the qualitative information that had been collected on the behavior of juvenile salmonids passing McNary Dam. In the past, the behavior of fish in the forebay was presented in a format that displayed the movements of each fish in three dimensions within a virtual rendition of the forebay of the dam. Most readers of this report will be familiar with the "fish track movies" using the Eonfusion ${ }^{\mathrm{TM}}$ software used in the past to display this information. That format allowed interested parties to observe visually how fish moved in different areas across the face of the dam and to examine how fish behavior might differ by species, time of day, passage route, or in response to the installation of a new passage alternative like the TSW. While this was, and still is, a useful way to examine the data, there was no convenient way to numerically summarize the information. The Markov chain analysis allowed us to numerically summarize the behavior of fish in the forebay.

Numerically summarizing the behavior of juvenile salmonids in the forebay of McNary Dam using the Markov chain analysis allowed us to confirm what previously had been subjectively evaluated using the Eonfusion ${ }^{\mathrm{TM}}$ visualization software. For example, within the powerhouse region, passage

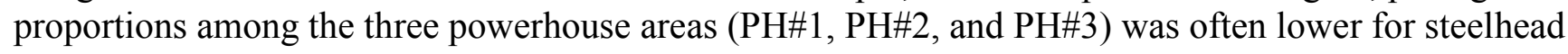
compared to the other three species, and the proportion of steelhead passing through the northern area was consistently lower than the passage proportions in the middle and south areas. These results confirmed that steelhead, which migrate closer to the surface of the water than the other species, did not pass readily into the deeper passage routes in the powerhouse. Similar reasoning can be used to explain why the passage proportions for the other three species in the powerhouse were higher than the passage proportions for steelhead. Chinook and sockeye salmon tend to travel deeper in the water and are more likely to enter the deeper passage routes in the powerhouse. Higher passage proportions in the northern area of the powerhouse for all species except steelhead may have been influenced by turbine operations. In most years, the turbines in this area were operated relatively high compared to the rest of the powerhouse (Adams and Liedtke, 2009) which might have resulted in increased passage proportions for fish that migrate deeper in the $\mathrm{PH} \# 3$ area.

The results of our analysis allowed us to confirm and quantify the extent of milling behavior that was observed for steelhead. For fish that were first detected in the powerhouse region, less than 0.17 (in most cases less than 0.10 ) of the steelhead passed within each of the powerhouse areas. Instead, steelhead appeared to transition to adjoining areas before passing the dam. In comparison, passage proportions in the powerhouse areas for the other three species were often more than double what was observed for steelhead, thus indicating that these species displayed considerably less milling behavior. Milling behavior was not as predominate for all species that first approached the spillway. Compared to the powerhouse areas, a higher proportion of fish, regardless of species, passed the spillway areas and fewer fish transitioned to adjoining areas. This was evident in 2006, when no temporary spillway weir (TSW) was installed in the spillway, and was more pronounced in subsequent years when TSWs were installed in the spillway. The surface oriented passage routes created by the TSWs resulted in more fish passage and less milling in the spillway areas.

In addition to quantifying what had been previously speculated about the behavior of fish in the forebay of McNary Dam, the Markov chain analysis refined our understanding of how fish behavior and passage can be influenced by changes to the operations and structure of McNary Dam. For example, the addition of TSWs to the spillway area clearly influenced the passage of fish. Previous results have been reported showing that TSWs increased passage through non-turbine routes and the fish-track videos indicated, in general, how fish behaved before passing the TSWs. However, the analysis presented in this report allowed us to better understand how fish transitioned across the face of the dam before 
passing the TSWs and resulted in a quantitative way to measure the effect of moving the location of the TSWs from year to year. Installation of the TSWs in bays 22 and 20 clearly increased passage proportions through the spillway area for all species, most significantly for steelhead. When the TSWs were moved to bays 19 and 20 in 2008, the overall passage through the spillway remained high but fewer fish passed through the TSWs and more fish passed through the bays. Shifting the TSWs to the north decreased the proportion of fish passing through the TSWs and increased the number of fish that transitioned to adjoining areas before passing the dam. During the spring of 2009, when only one TSW was installed in the southern spillway area, fewer fish passed through TSW 20 and more fish passed through the bays.

Results presented from the one-step Markov analyses allowed us to confirm and quantify what previously had been reported about the behavior of fish in the forebay of McNary Dam. The two-step analysis, however, resulted in quantitative information about the behavior of fish that has not been previously reported. For example, of the fish that passed the three areas in the powerhouse, the highest passage proportions were observed for fish that had transitioned from the forebay before passing. This indicated that fish were more likely to pass the powerhouse on their first approach and less likely to pass the powerhouse after transitioning laterally along the powerhouse. It is plausible that the depth fish approached the powerhouse contributed to this trend. Perhaps the proportion of the population within each species that migrated deeper passed the powerhouse on their first approach and the fish that migrated shallower tended to approach the powerhouse and move laterally before passing. This theory can be supported by the differences we observed between species. The proportion of steelhead passing the three powerhouse areas after transitioning from the forebay was lower than what was observed for the other three species. If a smaller proportion of the steelhead population is deep in the water column as they approach the dam, then less of the fish would pass through the deeper passage routes in the powerhouse on their first approach to the dam. This passage trend was not consistent in the spillway areas.

In the spillway, the proportion of fish that passed after transitioning from the forebay was nearly equal to the proportion that passed after transitioning from the powerhouse for yearling Chinook salmon and steelhead during 2006. For subyearling Chinook salmon, about one-half as many fish passed the spillway after transitioning from the forebay compared to the proportion that passed after transitioning from the powerhouse area. The two-step analysis also revealed that the addition of the TSWs in 2007, 2008, and 2009 altered passage proportions in the spillway. Unlike what was observed in the powerhouse where no surface oriented passage route existed, the addition of a surface passage route in the spillway decreased the milling behavior of fish as they approach the spillway.

Perhaps the most interesting new information to come out of the two-step analysis relates to how the performance of the TSWs was influenced by their proximity to the powerhouse. During 2007, the highest proportion of fish passing through TSW 22 was for fish that transitioned from the PH\#3 area. In contrast, a relatively low proportion of fish passed through TSW 20 after transitioning from the PH\#3 area. Instead, the proportion of fish that passed TSW 20 after coming from the forebay was sometimes twice as high as the proportion of fish that passed through TSW 20 after transitioning from the PH\#3 area. During 2008, the TSW in bay 22 was moved to bay 19, leaving the TSW in bay 20 as the one closest to the powerhouse. As was the case when a TSW was located in bay 22, the proportion of fish passing TSW 20 after transitioning from the $\mathrm{PH \# 3}$ area was higher than the proportion of fish passing TSW 20 after transitioning from the forebay. Passage proportions for fish passing through the TSW in bay 19, the farthest north of the two TSWs during 2008, was higher for fish that came from the forebay compared to the proportion of fish that passed through TSW 19 after coming from the PH\#3 area. 
The numerical results from the one-step Markov analysis were used to construct simulations to examine how future proposed structural and operational changes at McNary Dam might influence passage of juvenile salmonids. We presented the results of a simulated virtual fish collector (VFC) located in the PH\#2 area of the powerhouse. Results of the simulation indicated that a VFC would have a relatively localized effect on passage probabilities at McNary Dam, especially during years when TSWs also were installed. Simulations of this type can be used to estimate the performance of a VFC or other operational and structural changes before committing the resources to build, install, and test these relatively expensive structures.

This report is the second report published in 2012 that utilizes this analytical method. The first report included only fish released as part of the annual studies conducted at McNary Dam. This second report includes sockeye salmon that were released as part of the studies conducted by the public utility districts at the mid-Columbia River dams. Studies conducted in the mid-Columbia used transmitters with a shorter pulse width and no passive integrated transponder (PIT) tags were implanted in sockeye salmon. Differences in transmitters resulted in lower detection probabilities for sockeye salmon. These low detection probabilities hindered our ability to compare the behavior of sockeye to the behavior of the other three species. Additionally, the absence of PIT tags prevented us from determining if fish passed the powerhouse through the juvenile bypass system (JBS) or turbines. To facilitate comparison among species in this report, we combined JBS and turbine passage for yearling Chinook salmon, steelhead, and subyearling Chinook salmon even though we were able to differentiate between passage through the JBS or turbines for these three species. More detailed information on passage proportions through the JBS, turbines, and spillway can be found in the first report.

\section{Acknowledgments}

We thank Ann Setter, Brad Eby, Bill Prewitt, and individuals in the U.S. Army Corps of Engineers for their cooperation and assistance on the project. We are especially grateful to Rosanna Mensik and individuals working for the Washington Department of Fish and Wildlife for their assistance in collecting fish for the studies. We also greatly appreciate the U.S. Coast Guard, the U.S. Fish and Wildlife Service, the Portland District of the U.S. Army Corps of Engineers, and the Washington Department of Transportation for permission to install acoustic telemetry equipment on their property. We thank all of our colleagues at the Columbia River Research Laboratory for their assistance and dedication. Funding for this project was provided by the U.S. Army Corps of Engineers, Walla Walla District, Washington; Contract W68SBV03082690.

\section{References Cited}

Adams, N.S., and Counihan, T.D., eds., 2009, Survival and migration behavior of juvenile salmonids at McNary Dam, 2007: Final report of research prepared by U.S. Geological Survey, Cook, Washington, for the U.S. Army Corps of Engineers, Walla Walla District, Contract W68SBV70178419, Walla Walla, Washington.

Adams, N.S., and Evans, S.D., eds., 2011, Summary of juvenile salmonid passage and survival at McNary Dam-Acoustic survival studies, 2006-09: U.S. Geological Survey Open-File Report 2011$1179,144 \mathrm{p}$.

Adams, N.S., and Liedtke, T.L., eds., 2009, Juvenile salmonid survival, passage, and egress at McNary Dam during tests of temporary spillway weirs, 2008, Final report of research prepared by U.S. Geological Survey, Cook, Washington, for the U.S. Army Corps of Engineers, Walla Walla District, Contract W68SBV80448890. 
Adams, N.S., and Liedtke, T.L., eds., 2010, Juvenile salmonid survival, passage, and egress at McNary Dam during tests of temporary spillway weirs, 2009, Final report of research prepared by U.S. Geological Survey, Cook, Washington, for the U.S. Army Corps of Engineers, Walla Walla District, Contract W68SBV90070150.

Adams, N.S., Plumb, J.M., Hatton, T.W., Jones, E.C., Swyers, N.M., Sholtis, M.D., Reagan, R.E., and Cash, K.M., 2008, Survival and migration behavior of juvenile salmonids at McNary Dam, 2006: Final report of research prepared by U.S. Geological Survey, Cook, Washington, for the U.S. Army Corps of Engineers, Walla Walla District, Contract W68SBV60478899, Walla Walla, Washington. Adams, N.S., Rondorf, D.W, Evans, S.D., Kelly, J.E., and Perry, R.W., 1998, Effects of surgically and gastrically implanted radio transmitters on growth and feeding behavior of juvenile Chinook salmon: Transactions of the American Fisheries Society, v. 127, p. 128-136.

Adams, N.S., Walker, C.E, and Perry, R.W., 2011, A multi-year analysis of passage and survival at McNary Dam, 2004-09: U.S. Geological Survey Open-File Report 2011-1230, 128 p.

Axel, G.A., Hockersmith, E.E., Eppard, M.B., and Sanford, B.P., 2004a, Passage and survival of hatchery yearling Chinook salmon at McNary Dam, 2002: Report by National Marine Fisheries Service to U.S. Army Corps of Engineers, Walla Walla District, Contract W68SBV92844866, Walla Walla, Washington.

Axel, G.A., Hockersmith, E.E., Eppard, M.B., and Sanford, B.P., 2004b, Passage and survival of hatchery yearling Chinook salmon at McNary Dam, 2003: Report by National Marine Fisheries Service to U.S. Army Corps of Engineers, Walla Walla District, Contract W68SBV92844866, Walla Walla, Washington.

Beeman, J.W., Fielding, S.D., Braatz, A.C., Wilkerson, T.S., Pope, A.C., Walker, C.E., Hardiman, J.M., Perry, R.W., and Counihan, T.D., 2007, Survival and migration behavior of juvenile salmonids at Lower Granite Dam, 2006: Final report of research by the U. S. Geological Survey to the U.S. Army Corps of Engineers, Walla Walla District, Contract W68SBV60378208, Walla Walla, Washington. Johnson, G.E., Hedgepeth, J.B., Skalski, J.R., Giorgi, A.E., 2004, A Markov chain analysis of fish movements to determine entrainment zones: Fisheries Research, v. 69, 349-358

Perry, R.W., Braatz, A.C., Fielding, S.D., Lucchesi, J.N., Plumb, J.M., Adams, N.S., and Rondorf, D.W., 2006, Survival and migration behavior of juvenile salmonids at McNary Dam, 2004: Final report of research prepared by U.S. Geological Survey, Cook, Washington, for the U.S. Army Corps of Engineers, Walla Walla District, Contract W68SBV40271050, Walla Walla, Washington.

Perry, R.W., Braatz, A.C., Novick, M.S., Lucchesi, J.N., Rutz, G.L., Koch, R.C., Schei, J.S., Adams, N.S., and Rondorf, D.W., 2007a, Survival and migration behavior of juvenile salmonids at McNary Dam, 2005: Final report of research prepared by U.S. Geological Survey, Cook, Washington, for the U.S. Army Corps of Engineers, Walla Walla District, W68SBV50407617, Walla Walla, Washington Perry, R.W., Kock, T.J., Novick, M.S., Braatz, A.C., Fielding, S.D., Hansen, G.S., Sprando, J.M., Wilkerson, T.S., George, G.T., Schei, J.L., Adams, N.S., and Rondorf, D.W., 2007b, Survival and migration behavior of juvenile salmonids at Lower Granite Dam, 2005: Final report of research prepared by U.S. Geological Survey, Cook, Washington, for the U.S. Army Corps of Engineers, Walla Walla District, Contract W68SBV50498133, Walla Walla, Washington.

Plumb, J.M., Braatz, A.C., Lucchesi, J.N., Fielding, S.D., Cochran, A.D., Nation, T.K., Sprando, J.M., Schei, J.L., Perry, R.W., Adams, N.S., and Rondorf, D.W., 2004, Behavior and survival of radiotagged juvenile Chinook salmon and steelhead relative to the performance of a removable spillway weir at Lower Granite Dam, Washington, 2003: Final report of research prepared by U.S. Geological Survey, Cook, Washington, for the U.S. Army Corps of Engineers, Walla Walla District, Contract W68SBV00104592, Walla Walla, Washington. 
Puls, A.L., Counihan, T.D, Walker, C.E., Hardiman, J.M., and Duran, I.N., 2008, Survival and migration behavior of subyearling Chinook salmon at Lower Granite Dam, 2007: Final report of research prepared by U.S. Geological Survey, Cook, Washington, for the U.S. Army Corps of Engineers, Walla Walla District, Contract W68SBV70198655, Walla Walla, Washington.

Skalski, J.R., Townsend, R., Lady, J., Giorgi, A.E., Stevenson, J.R., and McDonald, R.S., 2002, Estimating route-specific passage and survival probabilities at a hydroelectric project from smolt radio telemetry studies: Canadian Journal of Fisheries and Aquatic Sciences, v. 59, p. 1385-1393. Steel, E., Guttorp, P., Anderson, J., Caccia, D., 2001, Modeling juvenile salmon migration using a simple Markov chain: Journal of Agriculture, Biological and Environmental Statistics, v. 6, p. 80-88.

Steig, T.W., Nealson, P.A., Kumagai, K.K., Rowdon, B.J., Klein, L.S., and McFadden, B.D., 2007, Route-specific passage of juvenile steelhead and sockeye salmon using acoustic tag methodologies at Rocky Reach and Rock Island Dams in 2006. Final report for Chelan County Public Utility District No. 1 by Hydroacoustic Technology, Inc.

Steig, T.W., Nealson, P.A., Kumagai, K.K., Rowdon, B.J., Klein, L.S., and McFadden, B.D., 2008, Route-specific passage of juvenile Chinook and sockeye salmon using acoustic tag methodologies at Rocky Reach and Rock Island Dams in 2007: Final report for Chelan County Public Utility District No. 1 by Hydroacoustic Technology, Inc..

Steig, T.W., Nealson, P.A., Kumagai, K.K., Rowdon, B.J., Selleck, J.R., and McFadden, B.D., 2009, Route specific passage of juvenile Chinook, sockeye and juvenile steelhead salmon using acoustic tag methodologies at Rocky Reach and Rock Island Dams in 2008: Final report for Chelan County Public Utility District No. 1 by Hydroacoustic Technology, Inc.

Steig, T.W., Nealson, P.A., Kumagai, K.K., Rowdon, B.J., Selleck, J.R., and Tunnicliffe, C., 2010, Route specific passage of juvenile Chinook, sockeye and juvenile steelhead salmon using acoustic tag methodologies at Rocky Reach and Rock Island Dams in 2009: Final report for Chelan County Public Utility District No. 1 by Hydroacoustic Technology, Inc.

Timko, M.A., Sullivan, L.S., Wright, C.D., Rizor, S.E., O’Connor, R.R., Skalski, J.R., Townsend, R.L., Fitzgerald, C.A., Meagher, M.M., Kukes, T.J., and Stephenson, J.D., 2010, Behavior and survival analysis of juvenile steelhead and sockeye through the Priest Rapids Hydroelectric Project in 2009: Final report for Grant County Public Utility District No. 2 by Blue Leaf Environmental. 


\section{Glossary}

\section{Forebay \\ NOAA Fisheries}

Near Dam

PIT

Powerhouse

RKM

Spillway

$\mathrm{SCH}$

SOC

STH

Tailrace

TSW

USACE

USGS

$\mathrm{YCH}$
Area of Columbia River extending from McNary Dam to $2 \mathrm{~km}$ upstream.

National Oceanic and Atmospheric Administration National Marine Fisheries Service.

Area of Columbia River extending from McNary Dam to approximately $160 \mathrm{~m}$ upstream; the area monitored by hydrophones placed from the upstream face of McNary Dam to $60 \mathrm{~m}$ upstream, including an average detection range of $100 \mathrm{~m}$. Passive integrated transponder.

Turbine and Bypass (units 1-14).

River kilometer.

Conventional spill bays (bays 1-22 excluding bays 20 and 22 in 2007, 19 and 20 in 2008, 4 and 20 in spring 2009, and 19 and 20 in summer 2009).

Subyearling Chinook salmon (Oncorhynchus tshawytscha).

Sockeye salmon (Oncorhynchus nerka).

Steelhead (Oncorhynchus mykiss).

Area of Columbia River extending from McNary Dam to $2.4 \mathrm{~km}$ downstream. Temporary Spillway Weir.

United States Army Corps of Engineers.

United States Geological Survey.

Yearling Chinook salmon (Oncorhynchus tshawytscha). 
Appendix A. Locations of Hydrophones in the McNary Dam Forebay, 2006-09.

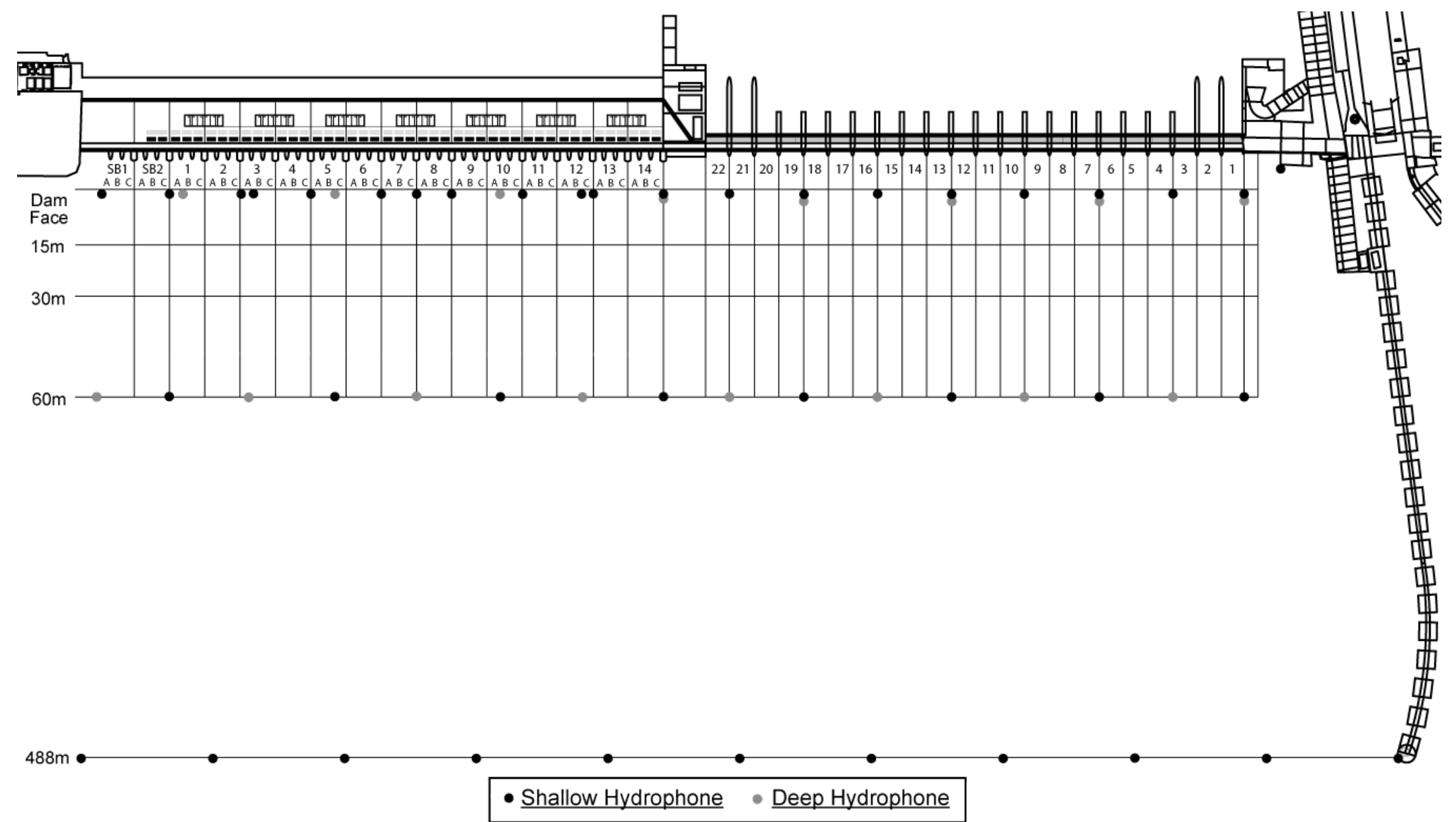

Figure A1. Schematic of hydrophones in the McNary Dam forebay during 2006. 


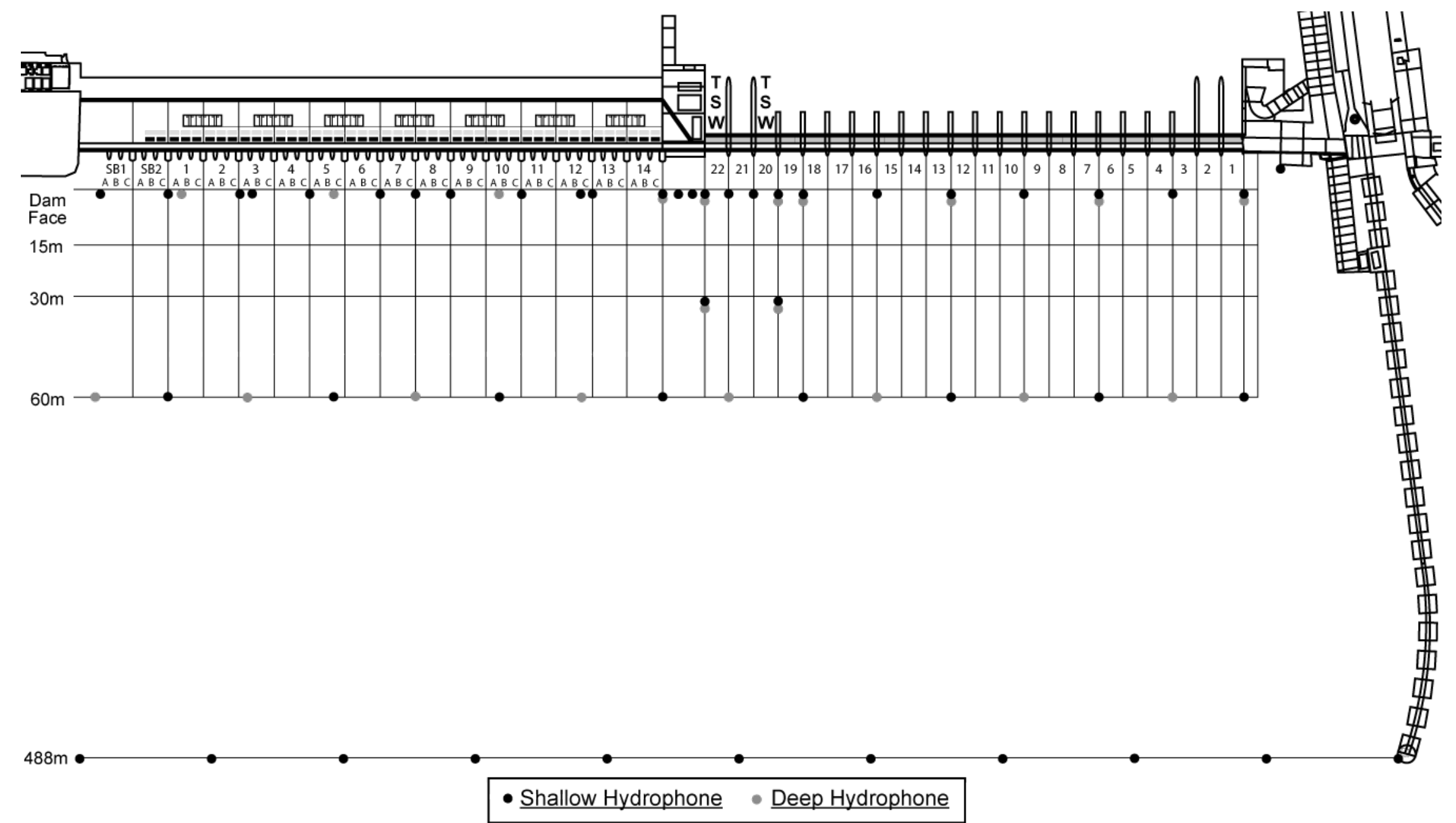

Figure A2. Schematic of hydrophones in the McNary Dam forebay during 2007. 


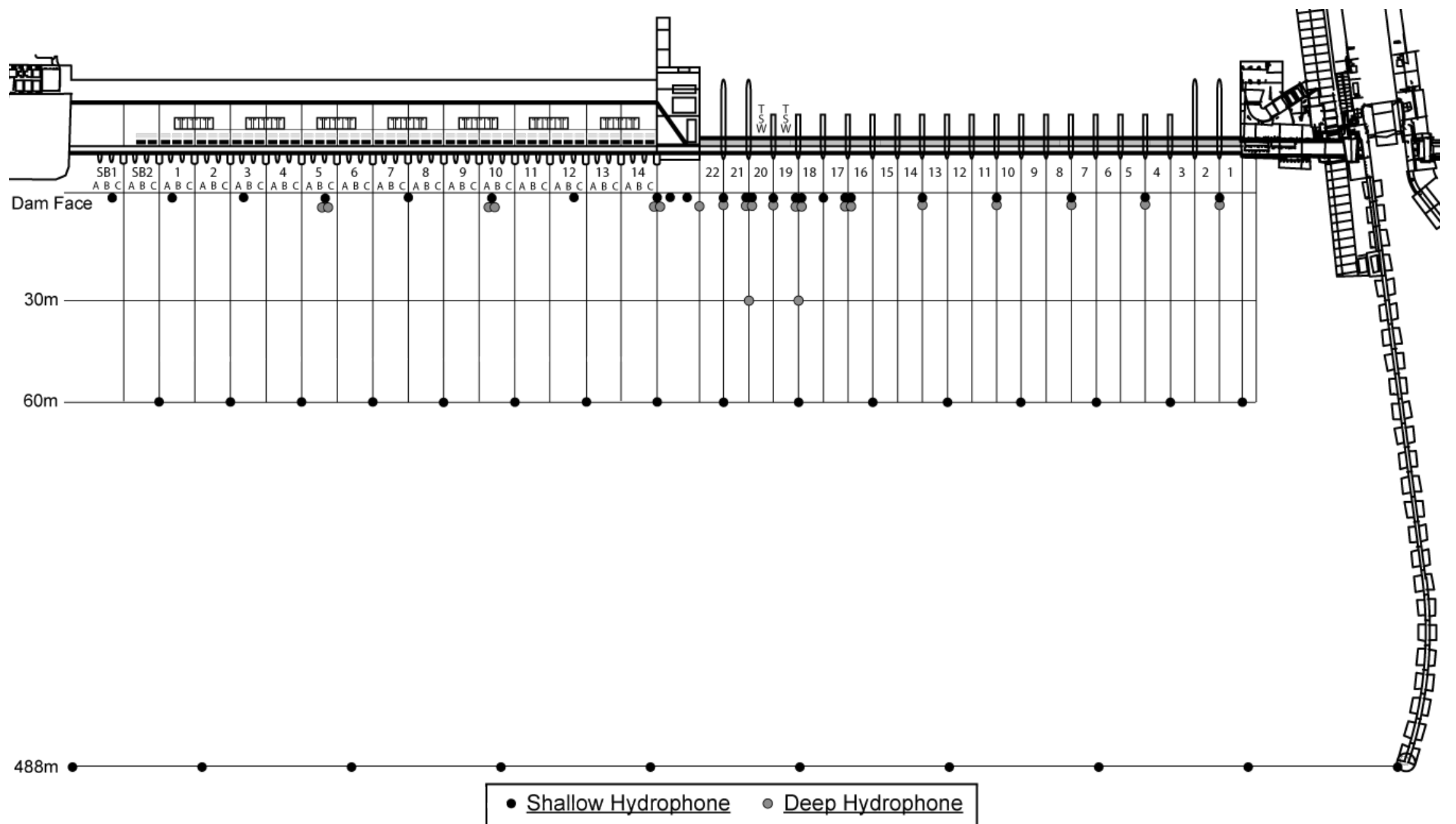

Figure A3. Schematic of hydrophones in the McNary Dam forebay during 2008. 


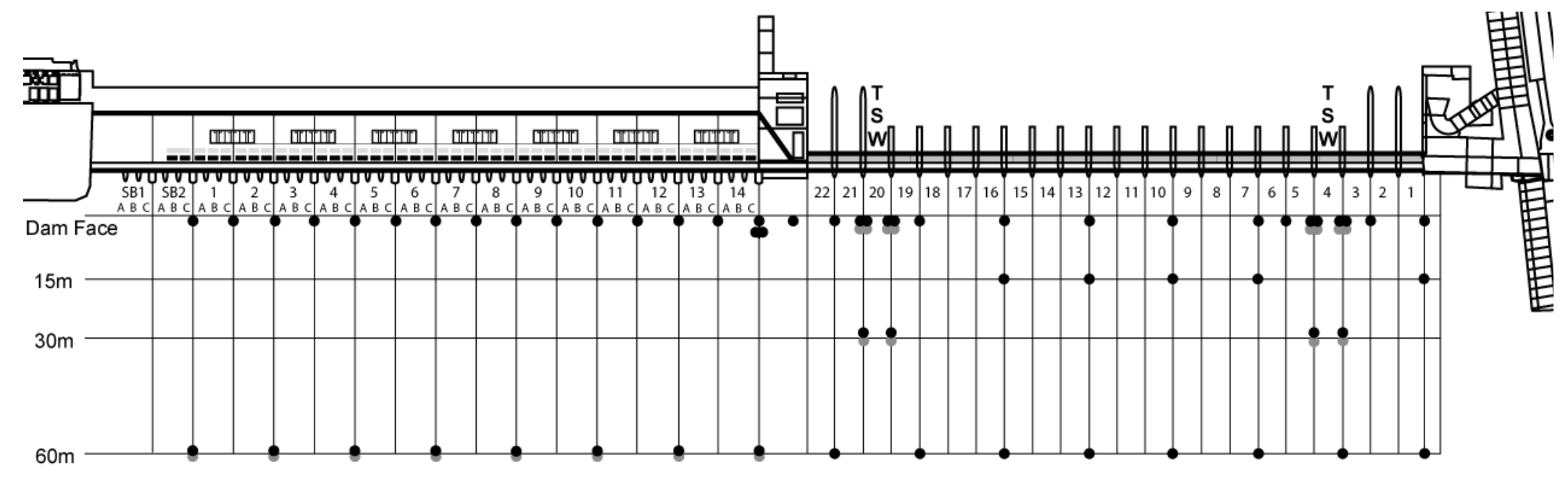

$488 \mathrm{~m} \bullet$

- Shallow Hydrophone - Deep Hydrophone

Figure A4. Schematic of hydrophones in the McNary Dam forebay during spring 2009. 

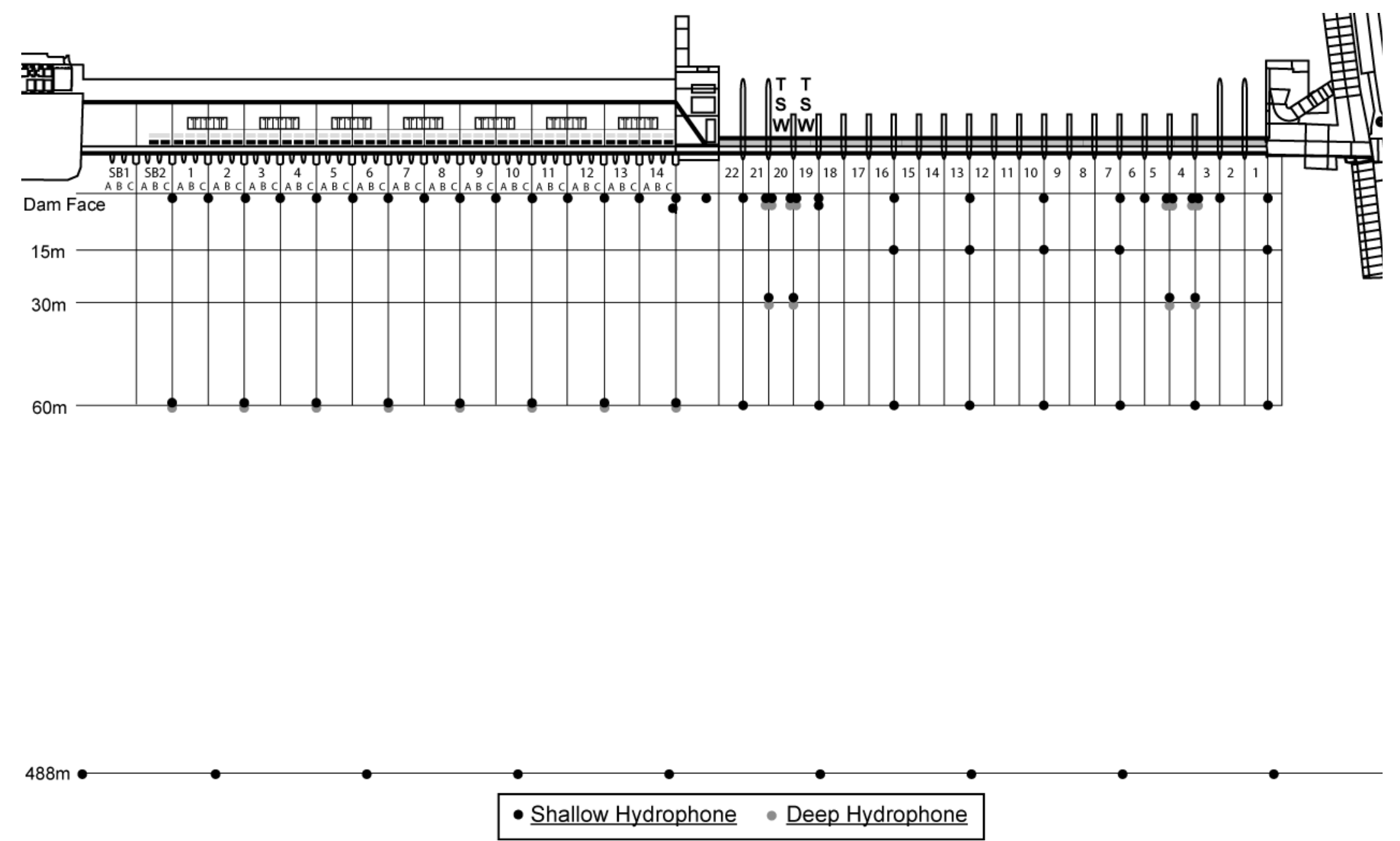

Figure A5. Schematic of hydrophones in the McNary Dam forebay during summer 2009. 


\section{Appendix B: Results from the 2006 to 2009 one-step Markov chain analysis for all fish regardless of where they first approached the dam during the day and night periods.}

Table B1. Percentage of fish passing McNary Dam during day period in 2006 based on a one-step Markov Chain analysis.

[Data represent all fish regardless of where they first approached the dam during the day period. Species: YCH, Yearling Chinook salmon; STH, juvenile steelhead; SCH, subyearling Chinook salmon; SOC, Sockeye salmon. Area of Passage: PH\#1, turbine units 1-5; PH\#2, turbine units 6-10; PH\#3, turbine units 11-14; Spillway, spill bays 1-22; TSW, temporary spillway weir; $(\backslash)$ denotes the TSW was not installed; Superscripts denote number of transitions used to calculate percentage: a, greater than 100; b , 50-100; c , 10 to 50; (*), less than 10, which was insufficient sample size to calculate percentage]

\begin{tabular}{|c|c|c|c|c|c|c|c|}
\hline \multicolumn{8}{|c|}{ Area of Passage } \\
\hline \multirow[b]{2}{*}{ Species } & $\mathrm{PH} \# 1$ & $\mathrm{PH} \# 2$ & $\mathrm{PH} \# 3$ & \multicolumn{4}{|c|}{ Spillway } \\
\hline & & & & $\underline{\text { TSW } 22}$ & TSW 20 & Bays & TSW 4 \\
\hline $\mathrm{YCH}$ & $14^{\mathrm{a}}$ & $20^{\mathrm{a}}$ & $24^{\mathrm{a}}$ & 1 & 1 & $94^{\mathrm{a}}$ & 1 \\
\hline STH & $11^{\mathrm{a}}$ & $8^{\mathrm{a}}$ & $7^{\mathrm{a}}$ & 1 & 1 & $75^{\mathrm{a}}$ & 1 \\
\hline $\mathrm{SCH}$ & $24^{\mathrm{a}}$ & $20^{\mathrm{a}}$ & $19^{\mathrm{a}}$ & 1 & 1 & $80^{\mathrm{a}}$ & 1 \\
\hline SOC & $23^{\mathrm{b}}$ & $54^{\mathrm{a}}$ & $57^{\mathrm{b}}$ & 1 & 1 & $*$ & 1 \\
\hline
\end{tabular}

Table B2. Percentage of fish passing McNary Dam during night period in 2006 based on a one-step Markov Chain analysis.

[Data represent all fish regardless of where they first approached the dam during the night period. Species: YCH, Yearling Chinook salmon; STH, juvenile steelhead; SCH, subyearling Chinook salmon; SOC, Sockeye salmon. Area of Passage: PH\#1, turbine units 1-5; PH\#2, turbine units 6-10; PH\#3, turbine units 11-14; Spillway, spill bays 1-22; TSW, temporary spillway weir; ( $\backslash$ denotes the TSW was not installed; Superscripts denote number of transitions used to calculate percentage: a, greater than $100 ; \mathrm{b}, 50-100 ; \mathrm{c}, 10$ to 50 ; (*), less than 10, which was insufficient sample size to calculate percentage]

\begin{tabular}{|c|c|c|c|c|c|c|c|}
\hline \multicolumn{8}{|c|}{ Area of Passage } \\
\hline \multirow[b]{2}{*}{ Species } & PH \#1 & $\mathrm{PH} \# 2$ & $\mathrm{PH} \# 3$ & \multicolumn{4}{|c|}{ Spillway } \\
\hline & & & & TSW 22 & $\underline{\text { TSW } 20}$ & Bays & TSW 4 \\
\hline $\mathrm{YCH}$ & $33^{\mathrm{a}}$ & $30^{\mathrm{a}}$ & $36^{\mathrm{a}}$ & 1 & 1 & $98^{\mathrm{a}}$ & 1 \\
\hline STH & $15^{\mathrm{a}}$ & $5^{\mathrm{a}}$ & $7^{\mathrm{a}}$ & 1 & 1 & $59^{\mathrm{a}}$ & 1 \\
\hline $\mathrm{SCH}$ & $16^{\mathrm{a}}$ & $13^{\mathrm{a}}$ & $7^{\mathrm{a}}$ & 1 & 1 & $79^{\mathrm{b}}$ & 1 \\
\hline SOC & $37^{\mathrm{c}}$ & $30^{\mathrm{b}}$ & $31^{\mathrm{c}}$ & 1 & 1 & $*$ & 1 \\
\hline
\end{tabular}




\section{Table B3. Percentage of fish passing McNary Dam during day period in 2007 based on a one-step Markov Chain analysis.}

[Data represent all fish regardless of where they first approached the dam during the day period. Species: YCH, Yearling Chinook salmon; STH, juvenile steelhead; SCH, subyearling Chinook salmon; SOC, Sockeye salmon. Area of Passage: PH\#1, turbine units 1-5; PH\#2, turbine units 6-10; PH\#3, turbine units 11-14; Spillway, spill bays 1-22; TSW, temporary spillway weir; $(\backslash)$ denotes the TSW was not installed; Superscripts denote number of transitions used to calculate percentage: a, greater than 100; b , 50-100; c , 10 to 50; (*), less than 10, which was insufficient sample size to calculate percentage]

\begin{tabular}{cc|c|c|cccc}
\hline & & \multicolumn{9}{c}{ Area of Passage } \\
Species & PH \#1 & PH \#2 & PH \#3 & \multicolumn{4}{c}{ Spillway } \\
\cline { 2 - 7 } & & & & $\underline{\text { TSW 22 }}$ & $\underline{\text { TSW 20 }}$ & $\underline{\text { Bays }}$ & $\underline{\text { TSW 4 }}$ \\
YCH & $20^{\mathrm{a}}$ & $28^{\mathrm{a}}$ & $19^{\mathrm{a}}$ & $35^{\mathrm{a}}$ & $14^{\mathrm{a}}$ & $43^{\mathrm{a}}$ & $\backslash$ \\
STH & $3^{\mathrm{a}}$ & $2^{\mathrm{a}}$ & $2^{\mathrm{a}}$ & $56^{\mathrm{a}}$ & $19^{\mathrm{a}}$ & $11^{\mathrm{a}}$ & $\backslash$ \\
SCH & $28^{\mathrm{a}}$ & $27^{\mathrm{a}}$ & $17^{\mathrm{a}}$ & $44^{\mathrm{a}}$ & $18^{\mathrm{a}}$ & $25^{\mathrm{a}}$ & $\backslash$ \\
SOC & $34^{\mathrm{a}}$ & $39^{\mathrm{a}}$ & $25^{\mathrm{b}}$ & $29^{\mathrm{c}}$ & $16^{\mathrm{c}}$ & $10^{\mathrm{c}}$ & $\backslash$ \\
\hline
\end{tabular}

Table B4. Percentage of fish passing McNary Dam during night period in 2007 based on a one-step Markov Chain analysis.

[Data represent all fish regardless of where they first approached the dam during the night period. Species: YCH, Yearling Chinook salmon; STH, juvenile steelhead; SCH, subyearling Chinook salmon; SOC, Sockeye salmon. Area of Passage: PH\#1, turbine units 1-5; PH\#2, turbine units 6-10; PH\#3, turbine units 11-14; Spillway, spill bays 1-22; TSW, temporary spillway weir; $(\backslash)$ denotes the TSW was not installed; Superscripts denote number of transitions used to calculate percentage: a, greater than 100; b , 50-100; c, 10 to 50; (*), less than 10 , which was insufficient sample size to calculate percentage]

\begin{tabular}{cc|c|c|cccc}
\hline & & \multicolumn{9}{c}{ Area of Passage } \\
Species & PH \#1 & PH \#2 & PH \#3 & \multicolumn{4}{c}{ Spillway } \\
\cline { 2 - 7 } & & & & $\underline{\text { TSW 22 }}$ & $\underline{\text { TSW 20 }}$ & $\underline{\text { Bays }}$ & $\underline{\text { TSW 4 }}$ \\
YCH & $25^{\mathrm{a}}$ & $25^{\mathrm{a}}$ & $18^{\mathrm{a}}$ & $41^{\mathrm{a}}$ & $12^{\mathrm{a}}$ & $37^{\mathrm{a}}$ & $\backslash$ \\
$\mathrm{STH}$ & $9^{\mathrm{a}}$ & $7^{\mathrm{a}}$ & $6^{\mathrm{a}}$ & $39^{\mathrm{a}}$ & $15^{\mathrm{a}}$ & $21^{\mathrm{a}}$ & $\backslash$ \\
$\mathrm{SCH}$ & $15^{\mathrm{a}}$ & $14^{\mathrm{a}}$ & $10^{\mathrm{a}}$ & $39^{\mathrm{a}}$ & $20^{\mathrm{a}}$ & $26^{\mathrm{a}}$ & $\backslash$ \\
SOC & $39^{\mathrm{a}}$ & $39^{\mathrm{a}}$ & $24^{\mathrm{b}}$ & $42^{\mathrm{c}}$ & $21^{\mathrm{c}}$ & $9^{\mathrm{c}}$ & $\backslash$ \\
\hline
\end{tabular}




\section{Table B5. Percentage of fish passing McNary Dam during day period in 2008 based on a one-step Markov Chain analysis.}

[Data represent all fish regardless of where they first approached the dam during the day period. Species: YCH, Yearling Chinook salmon; STH, juvenile steelhead; SCH, subyearling Chinook salmon; SOC, Sockeye salmon. Area of Passage: PH\#1, turbine units 1-5; PH\#2, turbine units 6-10; PH\#3, turbine units 11-14; Spillway, spill bays 1-22; TSW, temporary spillway weir; $(\backslash)$ denotes the TSW was not installed; Superscripts denote number of transitions used to calculate percentage: a, greater than 100; b , 50-100; c , 10 to 50; (*), less than 10, which was insufficient sample size to calculate percentage]

\begin{tabular}{|c|c|c|c|c|c|c|c|}
\hline \multicolumn{8}{|c|}{ Area of Passage } \\
\hline \multirow[b]{2}{*}{ Species } & $\mathrm{PH} \# 1$ & $\mathrm{PH} \# 2$ & $\mathrm{PH} \# 3$ & \multicolumn{4}{|c|}{ Spillway } \\
\hline & & & & $\underline{\text { TSW } 20}$ & TSW 19 & $\underline{\text { Bays }}$ & TSW 4 \\
\hline $\mathrm{YCH}$ & $15^{\mathrm{a}}$ & $22^{\mathrm{a}}$ & $23^{\mathrm{a}}$ & $23^{\mathrm{a}}$ & $24^{\mathrm{a}}$ & $35^{\mathrm{a}}$ & 1 \\
\hline STH & $7^{\mathrm{a}}$ & $3^{\mathrm{a}}$ & $7^{\mathrm{a}}$ & $36^{\mathrm{a}}$ & $21^{\mathrm{a}}$ & $18^{\mathrm{a}}$ & 1 \\
\hline $\mathrm{SCH}$ & $21^{\mathrm{a}}$ & $17^{\mathrm{a}}$ & $17^{\mathrm{a}}$ & $19^{\mathrm{a}}$ & $15^{\mathrm{a}}$ & $49^{\mathrm{a}}$ & 1 \\
\hline SOC & $36^{\mathrm{c}}$ & $82^{b}$ & $35^{\mathrm{c}}$ & $0^{c}$ & $0^{c}$ & $100^{c}$ & 1 \\
\hline
\end{tabular}

Table B6. Percentage of fish passing McNary Dam during night period in 2008 based on a one-step Markov Chain analysis.

[Data represent all fish regardless of where they first approached the dam during the night period. Species: YCH, Yearling Chinook salmon; STH, juvenile steelhead; SCH, subyearling Chinook salmon; SOC, Sockeye salmon. Area of Passage: PH\#1, turbine units 1-5; PH\#2, turbine units 6-10; PH\#3, turbine units 11-14; Spillway, spill bays 1-22; TSW, temporary spillway weir; ( $($ ) denotes the TSW was not installed; Superscripts denote number of transitions used to calculate percentage: a, greater than 100; b , 50-100; c , 10 to 50; (*), less than 10 , which was insufficient sample size to calculate percentage]

\begin{tabular}{|c|c|c|c|c|c|c|c|}
\hline \multicolumn{8}{|c|}{ Area of Passage } \\
\hline \multirow[b]{2}{*}{ Species } & $\mathrm{PH} \# 1$ & $\mathrm{PH} \# 2$ & $\mathrm{PH} \# 3$ & \multicolumn{4}{|c|}{ Spillway } \\
\hline & & & & TSW 20 & TSW 19 & Bays & TSW 4 \\
\hline $\mathrm{YCH}$ & $27^{\mathrm{b}}$ & $18^{\mathrm{a}}$ & $24^{\mathrm{a}}$ & $23^{\mathrm{b}}$ & $23^{b}$ & $28^{\mathrm{b}}$ & 1 \\
\hline STH & $17^{\mathrm{a}}$ & $10^{\mathrm{a}}$ & $12^{\mathrm{a}}$ & $23^{\mathrm{a}}$ & $12^{\mathrm{a}}$ & $27^{\mathrm{a}}$ & 1 \\
\hline $\mathrm{SCH}$ & $23^{\mathrm{a}}$ & $11^{\mathrm{a}}$ & $16^{\mathrm{a}}$ & $21^{\mathrm{b}}$ & $24^{\mathrm{b}}$ & $32^{\mathrm{b}}$ & 1 \\
\hline SOC & $*$ & $90^{\mathrm{c}}$ & $*$ & $*$ & $*$ & $*$ & 1 \\
\hline
\end{tabular}




\section{Table B7. Percentage of fish passing McNary Dam during day period in 2009 based on a one-step Markov Chain analysis.}

[Data represent all fish regardless of where they first approached the dam during the day period. Species: YCH, Yearling Chinook salmon; STH, juvenile steelhead; SCH, subyearling Chinook salmon; SOC, Sockeye salmon. Area of Passage: PH\#1, turbine units 1-5; PH\#2, turbine units 6-10; PH\#3, turbine units 11-14; Spillway, spill bays 1-22; TSW, temporary spillway weir; $(\backslash)$ denotes the TSW was not installed; Superscripts denote number of transitions used to calculate percentage: a, greater than 100; b , 50-100; c , 10 to 50; (*), less than 10, which was insufficient sample size to calculate percentage]

\begin{tabular}{cc|c|c|cccc}
\hline & & \multicolumn{9}{c}{ Area of Passage } \\
Species & PH \#1 & PH \#2 & PH \#3 & \multicolumn{4}{c}{ Spillway } \\
\cline { 2 - 7 } & & & & $\underline{\text { TSW 20 }}$ & $\underline{19}$ & $\underline{\text { Bays }}$ & $\underline{\text { TSW 4 }}$ \\
YCH & $21^{\mathrm{a}}$ & $17^{\mathrm{a}}$ & $29^{\mathrm{a}}$ & $15^{\mathrm{a}}$ & $\backslash$ & $66^{\mathrm{a}}$ & $6^{\mathrm{a}}$ \\
$\mathrm{STH}$ & $8^{\mathrm{a}}$ & $8^{\mathrm{a}}$ & $6^{\mathrm{a}}$ & $38^{\mathrm{a}}$ & $\backslash$ & $30^{\mathrm{a}}$ & $11^{\mathrm{a}}$ \\
SCH & $17^{\mathrm{a}}$ & $11^{\mathrm{a}}$ & $27^{\mathrm{a}}$ & $20^{\mathrm{a}}$ & $15^{\mathrm{a}}$ & $57^{\mathrm{a}}$ & $\backslash$ \\
SOC & $26^{\mathrm{a}}$ & $30^{\mathrm{a}}$ & $26^{\mathrm{a}}$ & $27^{\mathrm{a}}$ & 1 & $65^{\mathrm{a}}$ & $4^{\mathrm{a}}$ \\
\hline
\end{tabular}

Table B8. Percentage of fish passing McNary Dam during night period in 2009 based on a one-step Markov Chain analysis.

[Data represent all fish regardless of where they first approached the dam during the night period. Species: YCH, Yearling Chinook salmon; STH, juvenile steelhead; SCH, subyearling Chinook salmon; SOC, Sockeye salmon. Area of Passage: PH\#1, turbine units 1-5; PH\#2, turbine units 6-10; PH\#3, turbine units 11-14; Spillway, spill bays 1-22; TSW, temporary spillway weir; ( $($ ) denotes the TSW was not installed; Superscripts denote number of transitions used to calculate percentage: a, greater than 100; b , 50-100; c , 10 to 50; (*), less than 10 , which was insufficient sample size to calculate percentage]

\begin{tabular}{|c|c|c|c|c|c|c|c|}
\hline \multicolumn{8}{|c|}{ Area of Passage } \\
\hline \multirow[b]{2}{*}{ Species } & PH \#1 & $\mathrm{PH} \# 2$ & $\mathrm{PH} \# 3$ & \multicolumn{4}{|c|}{ Spillway } \\
\hline & & & & TSW 20 & TSW 19 & Bays & TSW 4 \\
\hline $\mathrm{YCH}$ & $19^{\mathrm{a}}$ & $18^{\mathrm{a}}$ & $27^{\mathrm{a}}$ & $16^{\mathrm{a}}$ & 1 & $63^{\mathrm{a}}$ & $8^{\mathrm{a}}$ \\
\hline STH & $12^{\mathrm{a}}$ & $8^{\mathrm{a}}$ & $10^{\mathrm{a}}$ & $19^{\mathrm{a}}$ & 1 & $44^{\mathrm{a}}$ & $11^{\mathrm{a}}$ \\
\hline $\mathrm{SCH}$ & $15^{\mathrm{a}}$ & $12^{\mathrm{a}}$ & $33^{\mathrm{a}}$ & $18^{\mathrm{a}}$ & $18^{\mathrm{a}}$ & $54^{\mathrm{a}}$ & 1 \\
\hline SOC & $35^{\mathrm{a}}$ & $33^{\mathrm{a}}$ & $27^{\mathrm{a}}$ & $28^{\mathrm{a}}$ & 1 & $60^{\mathrm{a}}$ & $8^{\mathrm{a}}$ \\
\hline
\end{tabular}




\section{Appendix C: Results from the 2006 to 2009 two-step Markov chain analysis for all fish regardless of where they first approached the dam during the day and night periods.}

Table C1. Percentage of fish passing McNary Dam during day period in 2006 based on a two-step Markov Chain analysis.

[Data represent all fish regardless of where they first approached the dam during the day period. Species: YCH, Yearling Chinook salmon; STH, juvenile steelhead; SCH, subyearling Chinook salmon; SOC, Sockeye salmon. Area of Passage: PH\#1, turbine units 1-5; PH\#2, turbine units 6-10; PH\#3, turbine units 11-14; Spillway, spill bays 1-22; Service Bay, equipment service bay on the south end of powerhouse; TSW, temporary spillway weir; ( () denotes the

TSW was not installed; Superscripts denote number of transitions used to calculate percentage: a, greater than 100; b , 50-100; c, 10 to 50; $(*)$, less than 10 , which was insufficient sample size to calculate percentage]

\begin{tabular}{|c|c|c|c|c|c|c|c|c|c|c|c|c|c|c|c|c|c|}
\hline $\begin{array}{c}\text { Area of } \\
\text { Passage: }\end{array}$ & \multicolumn{3}{|c|}{$\mathrm{PH} \# 1$} & \multicolumn{3}{|c|}{$\mathrm{PH} \# 2$} & \multicolumn{3}{|c|}{$\mathrm{PH} \# 3$} & \multicolumn{8}{|c|}{ Spillway } \\
\hline \multirow[b]{2}{*}{$\underline{\text { Species }}$} & $\begin{array}{l}\text { passing } \\
\text { PH\#1 } \\
\text { after } \\
\text { coming } \\
\text { from }\end{array}$ & $\begin{array}{l}\text { passing } \\
\text { PH\#1 } \\
\text { after } \\
\text { coming } \\
\text { from }\end{array}$ & $\begin{array}{l}\text { passing } \\
\text { PH\#1 } \\
\text { after } \\
\text { coming } \\
\text { from }\end{array}$ & $\begin{array}{l}\text { passing } \\
\text { PH\#2 } \\
\text { after } \\
\text { coming } \\
\text { from }\end{array}$ & $\begin{array}{l}\text { passing } \\
\text { PH\#2 } \\
\text { after } \\
\text { coming } \\
\text { from }\end{array}$ & $\begin{array}{l}\text { passing } \\
\text { PH\#2 } \\
\text { after } \\
\text { coming } \\
\text { from }\end{array}$ & $\begin{array}{l}\text { passing } \\
\text { PH\#3 } \\
\text { after } \\
\text { coming } \\
\text { from }\end{array}$ & $\begin{array}{l}\text { passing } \\
\text { PH\#3 } \\
\text { after } \\
\text { coming } \\
\text { from }\end{array}$ & $\begin{array}{l}\text { passing } \\
\text { PH\#3 } \\
\text { after } \\
\text { coming } \\
\text { from }\end{array}$ & $\begin{array}{l}\text { passi } \\
\text { comir }\end{array}$ & $\begin{array}{l}\text { spill } \\
\text { from }\end{array}$ & $\begin{array}{l}y \text { after } \\
\text { H3 }\end{array}$ & & $\begin{array}{l}\text { passi } \\
\text { comir }\end{array}$ & $\begin{array}{l}\text { g spillw } \\
\text { from } f\end{array}$ & $\begin{array}{l}\text { yy after } \\
\text { rebay }\end{array}$ & \\
\hline & & & & & & & & & & $\frac{\text { TSW }}{\underline{22}}$ & $\frac{\text { TSW }}{\underline{20}}$ & Bays & $\frac{\text { TSW }}{\underline{4}}$ & $\frac{\text { TSW }}{\underline{22}}$ & $\frac{\text { TSW }}{\underline{20}}$ & Bays & $\frac{\text { TSW }}{\underline{4}}$ \\
\hline $\mathrm{YCH}$ & $16^{\mathrm{b}}$ & $24^{\mathrm{b}}$ & $8^{\mathrm{a}}$ & $17^{\mathrm{a}}$ & $34^{\mathrm{b}}$ & $17^{\mathrm{a}}$ & $20^{\mathrm{a}}$ & $33^{b}$ & $7^{\mathrm{c}}$ & 1 & 1 & $95^{\mathrm{a}}$ & 1 & 1 & 1 & $94^{\mathrm{a}}$ & 1 \\
\hline STH & $5^{\mathrm{c}}$ & $21^{\mathrm{c}}$ & $6^{\mathrm{b}}$ & $7^{\mathrm{a}}$ & $24^{\mathrm{c}}$ & $4^{\mathrm{a}}$ & $4^{\mathrm{a}}$ & $23^{\mathrm{c}}$ & $4^{\mathrm{c}}$ & 1 & 1 & $75^{\mathrm{a}}$ & 1 & 1 & 1 & $73^{b}$ & 1 \\
\hline $\mathrm{SCH}$ & $24^{\mathrm{a}}$ & $37^{\mathrm{a}}$ & $17^{\mathrm{a}}$ & $19^{\mathrm{a}}$ & $30^{\mathrm{a}}$ & $16^{\mathrm{a}}$ & $14^{\mathrm{a}}$ & $30^{\mathrm{a}}$ & $10^{\mathrm{c}}$ & 1 & 1 & $94^{\mathrm{a}}$ & 1 & 1 & 1 & $41^{\mathrm{c}}$ & 1 \\
\hline SOC & $*$ & $16^{\mathrm{c}}$ & $50^{\mathrm{c}}$ & $54^{\mathrm{b}}$ & $50^{\mathrm{c}}$ & $63^{c}$ & $56^{\mathrm{c}}$ & $56^{\mathrm{c}}$ & $*$ & 1 & 1 & * & 1 & 1 & 1 & $*$ & 1 \\
\hline
\end{tabular}


Table C2. Percentage of fish passing McNary Dam during night period in 2006 based on a two-step Markov Chain analysis.

[Data represent all fish regardless of where they first approached the dam during the night period. Species: YCH, Yearling Chinook salmon; STH, juvenile steelhead; SCH, subyearling Chinook salmon; SOC, Sockeye salmon. Area of Passage: PH\#1, turbine units 1-5; PH\#2, turbine units 6-10; PH\#3, turbine units 11-14; Spillway, spill bays 1-22; Service Bay, equipment service bay on the south end of powerhouse; TSW, temporary spillway weir; ( () denotes the TSW was not installed; Superscripts denote number of transitions used to calculate percentage: a, greater than 100; b , 50-100; c , 10 to 50; (*), less than 10, which was insufficient sample size to calculate percentage]

\begin{tabular}{|c|c|c|c|c|c|c|c|c|c|c|c|c|c|c|c|c|c|}
\hline $\begin{array}{c}\text { Area of } \\
\text { Passage: }\end{array}$ & \multicolumn{3}{|c|}{$\mathrm{PH} \# 1$} & \multicolumn{3}{|c|}{$\mathrm{PH} \# 2$} & \multicolumn{3}{|c|}{$\mathrm{PH} \# 3$} & \multicolumn{8}{|c|}{ Spillway } \\
\hline \multirow[b]{2}{*}{ Species } & $\begin{array}{l}\text { passing } \\
\text { PH\#1 } \\
\text { after } \\
\text { coming } \\
\text { from }\end{array}$ & $\begin{array}{l}\text { passing } \\
\text { PH\#1 } \\
\text { after } \\
\text { coming } \\
\text { from }\end{array}$ & $\begin{array}{l}\text { passing } \\
\text { PH\#1 } \\
\text { after } \\
\text { coming } \\
\text { from }\end{array}$ & $\begin{array}{l}\text { passing } \\
\text { PH\#2 } \\
\text { after } \\
\text { coming } \\
\text { from }\end{array}$ & $\begin{array}{l}\text { passing } \\
\text { PH\#2 } \\
\text { after } \\
\text { coming } \\
\text { from }\end{array}$ & $\begin{array}{l}\text { passing } \\
\text { PH\#2 } \\
\text { after } \\
\text { coming } \\
\text { from }\end{array}$ & $\begin{array}{l}\text { passing } \\
\text { PH\#3 } \\
\text { after } \\
\text { coming } \\
\text { from }\end{array}$ & $\begin{array}{l}\text { passing } \\
\text { PH\#3 } \\
\text { after } \\
\text { coming } \\
\text { from }\end{array}$ & $\begin{array}{l}\text { passing } \\
\text { PH\#3 } \\
\text { after } \\
\text { coming } \\
\text { from }\end{array}$ & $\begin{array}{l}\text { passir } \\
\text { comin }\end{array}$ & $\begin{array}{l}\text { spill } \\
\text { from }\end{array}$ & $\begin{array}{l}y \text { afte } \\
\text {-\#3 }\end{array}$ & & $\begin{array}{l}\text { passin } \\
\text { comin }\end{array}$ & $\begin{array}{l}\text { g spilly } \\
\text { from }\end{array}$ & $\begin{array}{l}y \text { after } \\
\text { ebaay }\end{array}$ & \\
\hline & & & & & & & & & & $\frac{\text { TSW }}{\underline{22}}$ & $\frac{\text { TSW }}{\underline{20}}$ & Bays & $\frac{\frac{T S W}{4}}{\underline{4}}$ & $\frac{\text { TSW }}{\underline{22}}$ & $\frac{\text { TSW }}{\underline{20}}$ & Bays & $\frac{\text { TSW }}{\underline{4}}$ \\
\hline $\mathrm{YCH}$ & $34^{\mathrm{b}}$ & $58^{\mathrm{b}}$ & $16^{\mathrm{a}}$ & $17^{\mathrm{a}}$ & $62^{\mathrm{b}}$ & $17^{\mathrm{b}}$ & $20^{\mathrm{b}}$ & $57^{\mathrm{b}}$ & $*$ & 1 & 1 & $97^{\mathrm{c}}$ & 1 & 1 & 1 & $98^{\mathrm{a}}$ & 1 \\
\hline STH & $14^{\mathrm{b}}$ & $28^{\mathrm{b}}$ & $10^{\mathrm{a}}$ & $5^{\mathrm{a}}$ & $18^{\mathrm{b}}$ & $4^{\mathrm{a}}$ & $4^{\mathrm{a}}$ & $20^{\mathrm{b}}$ & $9^{a}$ & 1 & 1 & $62^{\mathrm{a}}$ & 1 & 1 & 1 & $53^{\mathrm{b}}$ & 1 \\
\hline $\mathrm{SCH}$ & $21^{\mathrm{b}}$ & $24^{\mathrm{b}}$ & $13^{\mathrm{a}}$ & $12^{\mathrm{a}}$ & $17^{\mathrm{b}}$ & $11^{\mathrm{a}}$ & $7^{\mathrm{a}}$ & $10^{\mathrm{b}}$ & $0^{c}$ & 1 & 1 & $90^{\mathrm{b}}$ & 1 & 1 & 1 & $54^{\mathrm{c}}$ & 1 \\
\hline SOC & $*$ & $7^{\mathrm{c}}$ & $52^{c}$ & $32^{\mathrm{c}}$ & $40^{\mathrm{c}}$ & $6^{c}$ & $37^{\mathrm{c}}$ & $25^{\mathrm{c}}$ & $*$ & 1 & 1 & $*$ & 1 & 1 & 1 & $*$ & 1 \\
\hline
\end{tabular}


Table C3. Percentage of fish passing McNary Dam during day period in 2007 based on a two-step Markov Chain analysis.

[Data represent all fish regardless of where they first approached the dam during the day period. Species: YCH, Yearling Chinook salmon; STH, juvenile steelhead; SCH, subyearling Chinook salmon; SOC, Sockeye salmon. Area of Passage: PH\#1, turbine units 1-5; PH\#2, turbine units 6-10; PH\#3, turbine units 11-14; Spillway, spill bays 1-22; Service Bay, equipment service bay on the south end of powerhouse; TSW, temporary spillway weir; (l) denotes the TSW was not installed; Superscripts denote number of transitions used to calculate percentage: a, greater than 100; b , 50-100; c, 10 to 50; $(*)$, less than 10, which was insufficient sample size to calculate percentage]

\begin{tabular}{|c|c|c|c|c|c|c|c|c|c|c|c|c|c|c|c|c|c|}
\hline $\begin{array}{c}\text { Area of } \\
\text { Passage: }\end{array}$ & \multicolumn{3}{|c|}{$\mathrm{PH} \# 1$} & \multicolumn{3}{|c|}{$\mathrm{PH} \# 2$} & \multicolumn{3}{|c|}{$\mathrm{PH} \# 3$} & \multicolumn{8}{|c|}{ Spillway } \\
\hline \multirow[b]{2}{*}{ Species } & $\begin{array}{l}\text { passing } \\
\text { PH\#1 } \\
\text { after } \\
\text { coming } \\
\text { from }\end{array}$ & $\begin{array}{l}\text { passing } \\
\text { PH\#1 } \\
\text { after } \\
\text { coming } \\
\text { from }\end{array}$ & $\begin{array}{l}\text { passing } \\
\text { PH\#1 } \\
\text { after } \\
\text { coming } \\
\text { from }\end{array}$ & $\begin{array}{l}\text { passing } \\
\text { PH\#2 } \\
\text { after } \\
\text { coming } \\
\text { from }\end{array}$ & $\begin{array}{l}\text { passing } \\
\text { PH\#2 } \\
\text { after } \\
\text { coming } \\
\text { from }\end{array}$ & $\begin{array}{l}\text { passing } \\
\text { PH\#2 } \\
\text { after } \\
\text { coming } \\
\text { from }\end{array}$ & $\begin{array}{l}\text { passing } \\
\mathrm{PH \# 3} \\
\text { after } \\
\text { coming } \\
\text { from }\end{array}$ & $\begin{array}{l}\text { passing } \\
\text { PH\#3 } \\
\text { after } \\
\text { coming } \\
\text { from }\end{array}$ & $\begin{array}{l}\text { passing } \\
\text { PH\#3 } \\
\text { after } \\
\text { coming } \\
\text { from }\end{array}$ & $\begin{array}{l}\text { passi } \\
\text { comir }\end{array}$ & $\begin{array}{l}\text { spilln } \\
\text { from }\end{array}$ & $\begin{array}{l}y \text { after } \\
\text { H\#3 }\end{array}$ & & $\begin{array}{l}\text { passi } \\
\text { comir }\end{array}$ & $\begin{array}{l}\text { g spillu } \\
\text { g from } \mathrm{f}\end{array}$ & $\begin{array}{l}\text { yy after } \\
\text { rebay }\end{array}$ & \\
\hline & & & & & & & & & & $\frac{\text { TSW }}{\underline{22}}$ & $\frac{\text { TSW }}{\underline{20}}$ & Bays & $\frac{\text { TSW }}{\underline{4}}$ & $\frac{\text { TSW }}{\underline{22}}$ & $\frac{\text { TSW }}{\underline{20}}$ & Bays & $\frac{\text { TSW }}{\underline{4}}$ \\
\hline $\mathrm{YCH}$ & $21^{\mathrm{b}}$ & $29^{\mathrm{a}}$ & $17^{\mathrm{a}}$ & $24^{\mathrm{a}}$ & $39^{\mathrm{a}}$ & $26^{\mathrm{a}}$ & $10^{\mathrm{a}}$ & $30^{\mathrm{a}}$ & $22^{\mathrm{c}}$ & $75^{\mathrm{a}}$ & $11^{\mathrm{a}}$ & $10^{\mathrm{a}}$ & 1 & $11^{\mathrm{a}}$ & $16^{\mathrm{a}}$ & $62^{\mathrm{a}}$ & 1 \\
\hline STH & $5^{a}$ & $3^{\mathrm{a}}$ & $3^{a}$ & $3^{\mathrm{a}}$ & $3^{a}$ & $1^{\mathrm{a}}$ & $2^{\mathrm{a}}$ & $2^{\mathrm{a}}$ & $1^{\mathrm{b}}$ & $75^{\mathrm{a}}$ & $11^{\mathrm{a}}$ & $4^{\mathrm{a}}$ & 1 & $19^{\mathrm{a}}$ & $35^{\mathrm{a}}$ & $25^{\mathrm{a}}$ & 1 \\
\hline $\mathrm{SCH}$ & $25^{\mathrm{a}}$ & $35^{\mathrm{a}}$ & $26^{\mathrm{a}}$ & $25^{\mathrm{a}}$ & $28^{\mathrm{a}}$ & $28^{\mathrm{a}}$ & $15^{\mathrm{a}}$ & $17^{\mathrm{a}}$ & $17^{\mathrm{c}}$ & $62^{\mathrm{a}}$ & $11^{\mathrm{a}}$ & $18^{\mathrm{a}}$ & 1 & $18^{\mathrm{b}}$ & $28^{\mathrm{b}}$ & $35^{\mathrm{b}}$ & 1 \\
\hline SOC & $38^{\mathrm{c}}$ & $34^{\mathrm{b}}$ & $32^{\mathrm{b}}$ & $32^{\mathrm{b}}$ & $42^{\mathrm{b}}$ & $47^{\mathrm{b}}$ & $20^{\mathrm{c}}$ & $17^{\mathrm{c}}$ & $64^{\mathrm{c}}$ & $58^{\mathrm{c}}$ & $8^{c}$ & $17^{\mathrm{c}}$ & 1 & $11^{\mathrm{c}}$ & $21^{\mathrm{c}}$ & $5^{c}$ & 1 \\
\hline
\end{tabular}


Table C4. Percentage of fish passing McNary Dam during night period in 2007 based on a two-step Markov Chain analysis.

[Data represent all fish regardless of where they first approached the dam during the night period. Species: YCH, Yearling Chinook salmon; STH, juvenile steelhead; SCH, subyearling Chinook salmon; SOC, Sockeye salmon. Area of Passage: PH\#1, turbine units 1-5; PH\#2, turbine units 6-10; PH\#3, turbine units 11-14; Spillway, spill bays 1-22; Service Bay, equipment service bay on the south end of powerhouse; TSW, temporary spillway weir; ( () denotes the TSW was not installed; Superscripts denote number of transitions used to calculate percentage: a, greater than 100; b , 50-100; c, 10 to 50; $(*)$, less than 10, which was insufficient sample size to calculate percentage]

\begin{tabular}{|c|c|c|c|c|c|c|c|c|c|c|c|c|c|c|c|c|c|}
\hline $\begin{array}{c}\text { Area of } \\
\text { Passage: }\end{array}$ & \multicolumn{3}{|c|}{$\mathrm{PH} \# 1$} & \multicolumn{3}{|c|}{$\mathrm{PH} \# 2$} & \multicolumn{3}{|c|}{$\mathrm{PH} \# 3$} & \multicolumn{8}{|c|}{ Spillway } \\
\hline \multirow[b]{2}{*}{ Species } & $\begin{array}{l}\text { passing } \\
\text { PH\#1 } \\
\text { after } \\
\text { coming } \\
\text { from }\end{array}$ & $\begin{array}{l}\text { passing } \\
\text { PH\#1 } \\
\text { after } \\
\text { coming } \\
\text { from }\end{array}$ & $\begin{array}{l}\text { passing } \\
\text { PH\#1 } \\
\text { after } \\
\text { coming } \\
\text { from }\end{array}$ & $\begin{array}{l}\text { passing } \\
\mathrm{PH \# 2} \\
\text { after } \\
\text { coming } \\
\text { from }\end{array}$ & $\begin{array}{l}\text { passing } \\
\text { PH\#2 } \\
\text { after } \\
\text { coming } \\
\text { from }\end{array}$ & $\begin{array}{l}\text { passing } \\
\text { PH\#2 } \\
\text { after } \\
\text { coming } \\
\text { from }\end{array}$ & $\begin{array}{l}\text { passing } \\
\text { PH\#3 } \\
\text { after } \\
\text { coming } \\
\text { from }\end{array}$ & $\begin{array}{l}\text { passing } \\
\text { PH\#3 } \\
\text { after } \\
\text { coming } \\
\text { from }\end{array}$ & $\begin{array}{l}\text { passing } \\
\text { PH\#3 } \\
\text { after } \\
\text { coming } \\
\text { from }\end{array}$ & $\begin{array}{l}\text { passi } \\
\text { comir }\end{array}$ & $\begin{array}{l}\text { spillw } \\
\text { from } F\end{array}$ & $\begin{array}{l}y \text { after } \\
\text { H3 }\end{array}$ & & $\begin{array}{l}\text { passi } \\
\text { comir }\end{array}$ & $\begin{array}{l}\text { g spillw } \\
\text { from } f\end{array}$ & $\begin{array}{l}\text { yy after } \\
\text { rebay }\end{array}$ & \\
\hline & & & & & & & & & & $\frac{\text { TSW }}{\underline{22}}$ & $\frac{\text { TSW }}{\underline{20}}$ & Bays & $\frac{\text { TSW }}{\underline{4}}$ & $\frac{\text { TSW }}{\underline{22}}$ & $\frac{\text { TSW }}{\underline{20}}$ & Bays & $\frac{\mathrm{TSW}}{\underline{4}}$ \\
\hline $\mathrm{YCH}$ & $31^{\mathrm{c}}$ & $39^{\mathrm{b}}$ & $14^{\mathrm{a}}$ & $21^{\mathrm{a}}$ & $28^{\mathrm{b}}$ & $29^{\mathrm{a}}$ & $9^{a}$ & $26^{\mathrm{b}}$ & $30^{\mathrm{c}}$ & $79^{\mathrm{b}}$ & $4^{b}$ & $16^{\mathrm{b}}$ & 1 & $17^{\mathrm{a}}$ & $17^{\mathrm{a}}$ & $50^{\mathrm{a}}$ & 1 \\
\hline STH & $12^{\mathrm{a}}$ & $14^{\mathrm{b}}$ & $5^{\mathrm{a}}$ & $5^{\mathrm{a}}$ & $9^{b}$ & $8^{\mathrm{a}}$ & $5^{\mathrm{a}}$ & $16^{\mathrm{b}}$ & $5^{b}$ & $51^{\mathrm{a}}$ & $16^{\mathrm{a}}$ & $16^{\mathrm{a}}$ & 1 & $16^{\mathrm{b}}$ & $12^{\mathrm{b}}$ & $30^{\mathrm{b}}$ & 1 \\
\hline $\mathrm{SCH}$ & $16^{\mathrm{b}}$ & $28^{\mathrm{b}}$ & $8^{\mathrm{a}}$ & $12^{\mathrm{a}}$ & $25^{\mathrm{b}}$ & $11^{\mathrm{b}}$ & $9^{a}$ & $10^{\mathrm{b}}$ & $20^{c}$ & $49^{\mathrm{a}}$ & $15^{\mathrm{a}}$ & $26^{\mathrm{a}}$ & 1 & $27^{\mathrm{b}}$ & $27^{\mathrm{b}}$ & $27^{\mathrm{b}}$ & 1 \\
\hline $\mathrm{SOC}$ & $37^{\mathrm{c}}$ & $44^{\mathrm{b}}$ & $33^{c}$ & $34^{\mathrm{b}}$ & $38^{\mathrm{c}}$ & $49^{c}$ & $19^{c}$ & $15^{\mathrm{c}}$ & $*$ & $59^{c}$ & $24^{\mathrm{c}}$ & $6^{\mathrm{c}}$ & 1 & $25^{\mathrm{c}}$ & $19^{c}$ & $13^{c}$ & 1 \\
\hline
\end{tabular}


Table C5. Percentage of fish passing McNary Dam during day period in 2008 based on a two-step Markov Chain analysis.

[Data represent all fish regardless of where they first approached the dam during the day period. Species: YCH, Yearling Chinook salmon; STH, juvenile steelhead; SCH, subyearling Chinook salmon; SOC, Sockeye salmon. Area of Passage: PH\#1, turbine units 1-5; PH\#2, turbine units 6-10; PH\#3, turbine units 11-14; Spillway, spill bays 1-22; Service Bay, equipment service bay on the south end of powerhouse; TSW, temporary spillway weir; (l) denotes the TSW was not installed; Superscripts denote number of transitions used to calculate percentage: a, greater than 100; b , 50-100; c, 10 to 50; $(*)$, less than 10, which was insufficient sample size to calculate percentage]

\begin{tabular}{|c|c|c|c|c|c|c|c|c|c|c|c|c|c|c|c|c|c|}
\hline $\begin{array}{c}\text { Area of } \\
\text { Passage: }\end{array}$ & \multicolumn{3}{|c|}{$\mathrm{PH} \# 1$} & \multicolumn{3}{|c|}{$\mathrm{PH} \# 2$} & \multicolumn{3}{|c|}{$\mathrm{PH} \# 3$} & \multicolumn{8}{|c|}{ Spillway } \\
\hline \multirow[b]{2}{*}{ Species } & $\begin{array}{l}\text { passing } \\
\text { PH\#1 } \\
\text { after } \\
\text { coming } \\
\text { from }\end{array}$ & $\begin{array}{l}\text { passing } \\
\text { PH\#1 } \\
\text { after } \\
\text { coming } \\
\text { from }\end{array}$ & $\begin{array}{l}\text { passing } \\
\text { PH\#1 } \\
\text { after } \\
\text { coming } \\
\text { from }\end{array}$ & $\begin{array}{l}\text { passing } \\
\text { PH\#2 } \\
\text { after } \\
\text { coming } \\
\text { from }\end{array}$ & $\begin{array}{l}\text { passing } \\
\text { PH\#2 } \\
\text { after } \\
\text { coming } \\
\text { from }\end{array}$ & $\begin{array}{l}\text { passing } \\
\text { PH\#2 } \\
\text { after } \\
\text { coming } \\
\text { from }\end{array}$ & $\begin{array}{l}\text { passing } \\
\mathrm{PH \# 3} \\
\text { after } \\
\text { coming } \\
\text { from }\end{array}$ & $\begin{array}{l}\text { passing } \\
\text { PH\#3 } \\
\text { after } \\
\text { coming } \\
\text { from }\end{array}$ & $\begin{array}{l}\text { passing } \\
\text { PH\#3 } \\
\text { after } \\
\text { coming } \\
\text { from }\end{array}$ & $\begin{array}{l}\text { passi } \\
\text { comir }\end{array}$ & $\begin{array}{l}\text { spillv } \\
\text { from }\end{array}$ & $\begin{array}{l}y \text { after } \\
\text { H\#3 }\end{array}$ & & $\begin{array}{l}\text { passi } \\
\text { comir }\end{array}$ & $\begin{array}{l}\text { g spillu } \\
\text { g from } \mathrm{f}\end{array}$ & $\begin{array}{l}\text { yy after } \\
\text { rebay }\end{array}$ & \\
\hline & & & & & & & & & & $\frac{\text { TSW }}{\underline{20}}$ & $\frac{\text { TSW }}{\underline{19}}$ & Bays & $\frac{\text { TSW }}{\underline{4}}$ & $\frac{\text { TSW }}{\underline{20}}$ & $\frac{\text { TSW }}{\underline{19}}$ & Bays & $\frac{\mathrm{TSW}}{\underline{4}}$ \\
\hline $\mathrm{YCH}$ & $17^{\mathrm{c}}$ & $13^{c}$ & $16^{\mathrm{b}}$ & $21^{\mathrm{a}}$ & $31^{\mathrm{c}}$ & $16^{\mathrm{b}}$ & $23^{b}$ & $14^{\mathrm{c}}$ & $33^{c}$ & $33^{b}$ & $16^{\mathrm{b}}$ & $40^{\mathrm{b}}$ & 1 & $15^{\mathrm{b}}$ & $31^{\mathrm{b}}$ & $32^{\mathrm{b}}$ & 1 \\
\hline STH & $5^{c}$ & $11^{\mathrm{c}}$ & $5^{\mathrm{b}}$ & $4^{\mathrm{a}}$ & $0^{c}$ & $5^{b}$ & $6^{\mathrm{a}}$ & $3^{b}$ & $14^{\mathrm{b}}$ & $44^{\mathrm{a}}$ & $20^{\mathrm{a}}$ & $17^{\mathrm{a}}$ & 1 & $12^{\mathrm{b}}$ & $24^{\mathrm{b}}$ & $20^{\mathrm{b}}$ & 1 \\
\hline $\mathrm{SCH}$ & $13^{\mathrm{a}}$ & $31^{\mathrm{a}}$ & $19^{\mathrm{a}}$ & $18^{\mathrm{a}}$ & $25^{\mathrm{b}}$ & $2^{\mathrm{b}}$ & $15^{\mathrm{a}}$ & $12^{\mathrm{c}}$ & $27^{\mathrm{c}}$ & $20^{\mathrm{a}}$ & $14^{\mathrm{a}}$ & $56^{\mathrm{a}}$ & 1 & $18^{\mathrm{b}}$ & $18^{\mathrm{b}}$ & $36^{\mathrm{b}}$ & 1 \\
\hline $\mathrm{SOC}$ & $*$ & $36^{\mathrm{c}}$ & $*$ & $88^{\mathrm{c}}$ & $81^{\mathrm{c}}$ & $*$ & $*$ & $31^{\mathrm{c}}$ & $*$ & $*$ & $*$ & * & 1 & $*$ & $*$ & $*$ & 1 \\
\hline
\end{tabular}


Table C6. Percentage of fish passing McNary Dam during night period in 2008 based on a two-step Markov Chain analysis.

[Data represent all fish regardless of where they first approached the dam during the night period. Species: YCH, Yearling Chinook salmon; STH, juvenile steelhead; SCH, subyearling Chinook salmon; SOC, Sockeye salmon. Area of Passage: PH\#1, turbine units 1-5; PH\#2, turbine units 6-10; PH\#3, turbine units 11-14; Spillway, spill bays 1-22; Service Bay, equipment service bay on the south end of powerhouse; TSW, temporary spillway weir; ( $($ ) denotes the TSW was not installed; Superscripts denote number of transitions used to calculate percentage: a, greater than 100; b , 50-100; c, 10 to 50; $(*)$, less than 10, which was insufficient sample size to calculate percentage]

\begin{tabular}{|c|c|c|c|c|c|c|c|c|c|c|c|c|c|c|c|c|c|}
\hline $\begin{array}{c}\text { Area of } \\
\text { Passage: }\end{array}$ & \multicolumn{3}{|c|}{$\mathrm{PH} \# 1$} & \multicolumn{3}{|c|}{$\mathrm{PH} \# 2$} & \multicolumn{3}{|c|}{$\mathrm{PH} \# 3$} & \multicolumn{8}{|c|}{ Spillway } \\
\hline \multirow[b]{2}{*}{ Species } & $\begin{array}{l}\text { passing } \\
\mathrm{PH \# 1} \\
\text { after } \\
\text { coming } \\
\text { from }\end{array}$ & $\begin{array}{l}\text { passing } \\
\mathrm{PH \# 1} \\
\text { after } \\
\text { coming } \\
\text { from }\end{array}$ & $\begin{array}{l}\text { passing } \\
\mathrm{PH \# 1} \\
\text { after } \\
\text { coming } \\
\text { from }\end{array}$ & $\begin{array}{l}\text { passing } \\
\mathrm{PH \# 2} \\
\text { after } \\
\text { coming } \\
\text { from }\end{array}$ & $\begin{array}{l}\text { passing } \\
\text { PH\#2 } \\
\text { after } \\
\text { coming } \\
\text { from }\end{array}$ & $\begin{array}{l}\text { passing } \\
\text { PH\#2 } \\
\text { after } \\
\text { coming } \\
\text { from }\end{array}$ & $\begin{array}{l}\text { passing } \\
\mathrm{PH \# 3} \\
\text { after } \\
\text { coming } \\
\text { from }\end{array}$ & $\begin{array}{l}\text { passing } \\
\text { PH\#3 } \\
\text { after } \\
\text { coming } \\
\text { from }\end{array}$ & $\begin{array}{l}\text { passing } \\
\text { PH\#3 } \\
\text { after } \\
\text { coming } \\
\text { from }\end{array}$ & $\begin{array}{l}\text { passi } \\
\text { comir }\end{array}$ & $\begin{array}{l}\text { spillw } \\
\text { from } F\end{array}$ & $\begin{array}{l}y \text { after } \\
\text { H3 }\end{array}$ & & $\begin{array}{l}\text { passi } \\
\text { comir }\end{array}$ & $\begin{array}{l}\text { g spillu } \\
\text { from f }\end{array}$ & $\begin{array}{l}\text { yy after } \\
\text { rebay }\end{array}$ & \\
\hline & & & & & & & & & & $\frac{\text { TSW }}{\underline{20}}$ & $\frac{\text { TSW }}{\underline{19}}$ & Bays & $\frac{\text { TSW }}{\underline{4}}$ & $\frac{\text { TSW }}{\underline{20}}$ & $\frac{\text { TSW }}{\underline{19}}$ & Bays & $\frac{\mathrm{TSW}}{\underline{4}}$ \\
\hline $\mathrm{YCH}$ & $20^{\mathrm{c}}$ & $37^{\mathrm{c}}$ & $22^{c}$ & $16^{\mathrm{b}}$ & $16^{\mathrm{c}}$ & $24^{\mathrm{c}}$ & $18^{\mathrm{c}}$ & $15^{\mathrm{c}}$ & $46^{\mathrm{c}}$ & $36^{\mathrm{c}}$ & $18^{\mathrm{c}}$ & $24^{\mathrm{c}}$ & 1 & $9^{c}$ & $27^{\mathrm{c}}$ & $32^{\mathrm{c}}$ & 1 \\
\hline STH & $12^{\mathrm{b}}$ & $29^{\mathrm{b}}$ & $13^{\mathrm{a}}$ & $15^{\mathrm{a}}$ & $4^{\mathrm{c}}$ & $4^{b}$ & $8^{\mathrm{a}}$ & $11^{\mathrm{b}}$ & $23^{b}$ & $29^{\mathrm{a}}$ & $10^{\mathrm{a}}$ & $28^{\mathrm{a}}$ & 1 & $7^{b}$ & $18^{\mathrm{b}}$ & $25^{\mathrm{b}}$ & 1 \\
\hline $\mathrm{SCH}$ & $21^{\mathrm{b}}$ & $31^{\mathrm{b}}$ & $19^{\mathrm{b}}$ & $13^{b}$ & $12^{\mathrm{c}}$ & $6^{\mathrm{c}}$ & $13^{\mathrm{b}}$ & $13^{\mathrm{c}}$ & $29^{c}$ & $24^{\mathrm{b}}$ & $22^{\mathrm{b}}$ & $37^{\mathrm{b}}$ & 1 & $18^{\mathrm{c}}$ & $26^{\mathrm{c}}$ & $24^{\mathrm{c}}$ & 1 \\
\hline SOC & $*$ & $*$ & $*$ & $*$ & $*$ & $*$ & $*$ & $*$ & $*$ & $*$ & $*$ & $*$ & 1 & $*$ & $*$ & $*$ & 1 \\
\hline
\end{tabular}


Table C7. Percentage of fish passing McNary Dam during day period in 2009 based on a two-step Markov Chain analysis.

[Data represent all fish regardless of where they first approached the dam during the day period. Species: YCH, Yearling Chinook salmon; STH, juvenile steelhead; SCH, subyearling Chinook salmon; SOC, Sockeye salmon. Area of Passage: PH\#1, turbine units 1-5; PH\#2, turbine units 6-10; PH\#3, turbine units 11-14; Spillway, spill bays 1-22; Service Bay, equipment service bay on the south end of powerhouse; TSW, temporary spillway weir; (l) denotes the TSW was not installed; Superscripts denote number of transitions used to calculate percentage: a, greater than 100; b , 50-100; c, 10 to 50; (*), less than 10 , which was insufficient sample size to calculate percentage]

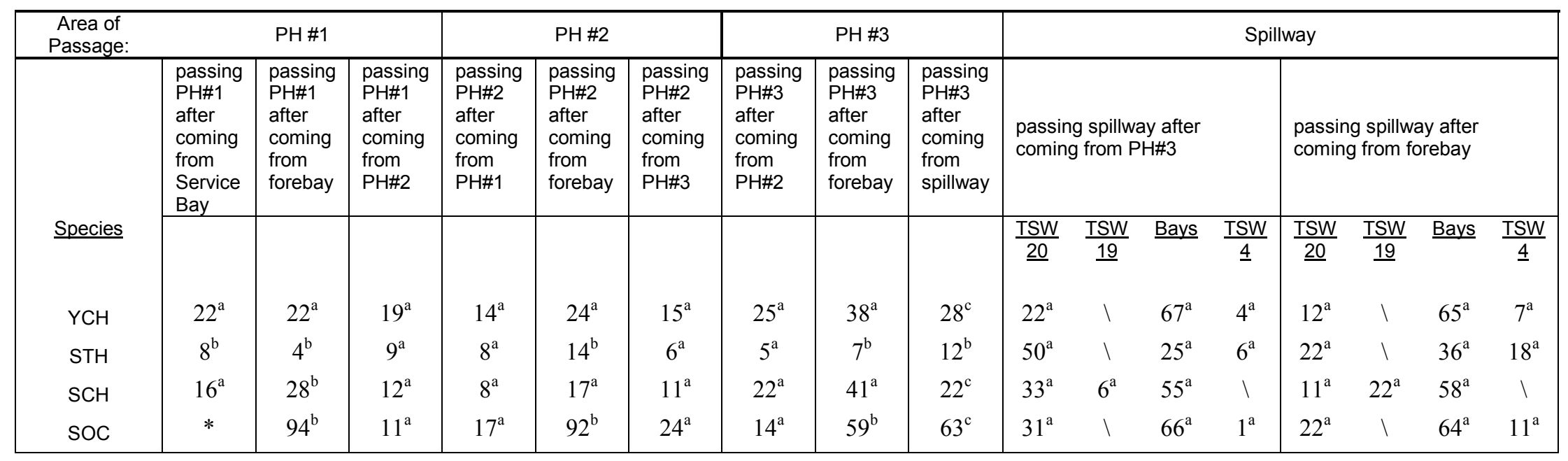


Table C8. Percentage of fish passing McNary Dam during night period in 2009 based on a two-step Markov Chain analysis.

[Data represent all fish regardless of where they first approached the dam during the night period. Species: YCH, Yearling Chinook salmon; STH, juvenile steelhead; SCH, subyearling Chinook salmon; SOC, Sockeye salmon. Area of Passage: PH\#1, turbine units 1-5; PH\#2, turbine units 6-10; PH\#3, turbine units 11-14; Spillway, spill bays 1-22; Service Bay, equipment service bay on the south end of powerhouse; TSW, temporary spillway weir; ( $($ ) denotes the TSW was not installed; Superscripts denote number of transitions used to calculate percentage: a, greater than 100; b , 50-100; c, 10 to 50; $(*)$, less than 10, which was insufficient sample size to calculate percentage]

\begin{tabular}{|c|c|c|c|c|c|c|c|c|c|c|c|c|c|c|c|c|c|}
\hline $\begin{array}{c}\text { Area of } \\
\text { Passage: }\end{array}$ & \multicolumn{3}{|c|}{$\mathrm{PH} \# 1$} & \multicolumn{3}{|c|}{$\mathrm{PH} \# 2$} & \multicolumn{3}{|c|}{$\mathrm{PH} \# 3$} & \multicolumn{8}{|c|}{ Spillway } \\
\hline \multirow[b]{2}{*}{ Species } & $\begin{array}{l}\text { passing } \\
\text { PH\#1 } \\
\text { after } \\
\text { coming } \\
\text { from }\end{array}$ & $\begin{array}{l}\text { passing } \\
\text { PH\#1 } \\
\text { after } \\
\text { coming } \\
\text { from }\end{array}$ & $\begin{array}{l}\text { passing } \\
\text { PH\#1 } \\
\text { after } \\
\text { coming } \\
\text { from }\end{array}$ & $\begin{array}{l}\text { passing } \\
\mathrm{PH \# 2} \\
\text { after } \\
\text { coming } \\
\text { from }\end{array}$ & $\begin{array}{l}\text { passing } \\
\text { PH\#2 } \\
\text { after } \\
\text { coming } \\
\text { from }\end{array}$ & $\begin{array}{l}\text { passing } \\
\text { PH\#2 } \\
\text { after } \\
\text { coming } \\
\text { from }\end{array}$ & $\begin{array}{l}\text { passing } \\
\text { PH\#3 } \\
\text { after } \\
\text { coming } \\
\text { from }\end{array}$ & $\begin{array}{l}\text { passing } \\
\text { PH\#3 } \\
\text { after } \\
\text { coming } \\
\text { from }\end{array}$ & $\begin{array}{l}\text { passing } \\
\text { PH\#3 } \\
\text { after } \\
\text { coming } \\
\text { from }\end{array}$ & $\begin{array}{l}\text { passi } \\
\text { comir }\end{array}$ & $\begin{array}{l}\text { spillw } \\
\text { from } F\end{array}$ & $\begin{array}{l}y \text { after } \\
-\# 3\end{array}$ & & $\begin{array}{l}\text { passi } \\
\text { comir }\end{array}$ & $\begin{array}{l}\text { g spillw } \\
\text { from } f\end{array}$ & $\begin{array}{l}\text { yy after } \\
\text { rebay }\end{array}$ & \\
\hline & & & & & & & & & & $\frac{\text { TSW }}{\underline{20}}$ & $\frac{\text { TSW }}{\underline{19}}$ & Bays & $\frac{\text { TSW }}{\underline{4}}$ & $\frac{\text { TSW }}{\underline{20}}$ & $\frac{\text { TSW }}{\underline{19}}$ & Bays & $\frac{\mathrm{TSW}}{\underline{4}}$ \\
\hline $\mathrm{YCH}$ & $24^{\mathrm{b}}$ & $34^{\mathrm{b}}$ & $10^{\mathrm{a}}$ & $13^{\mathrm{a}}$ & $39^{\mathrm{b}}$ & $15^{\mathrm{a}}$ & $15^{\mathrm{a}}$ & $42^{b}$ & $43^{c}$ & $26^{\mathrm{b}}$ & 1 & $59^{\mathrm{b}}$ & $3^{b}$ & $12^{\mathrm{a}}$ & 1 & $64^{\mathrm{a}}$ & $9^{\mathrm{a}}$ \\
\hline STH & $12^{\mathrm{a}}$ & $16^{\mathrm{a}}$ & $10^{\mathrm{a}}$ & $6^{\mathrm{a}}$ & $21^{b}$ & $8^{\mathrm{a}}$ & $8^{\mathrm{a}}$ & $22^{\mathrm{b}}$ & $11^{\mathrm{a}}$ & $25^{\mathrm{a}}$ & 1 & $39^{\mathrm{a}}$ & $9^{\mathrm{a}}$ & $12^{\mathrm{a}}$ & 1 & $48^{\mathrm{a}}$ & $12^{\mathrm{a}}$ \\
\hline $\mathrm{SCH}$ & $11^{\mathrm{a}}$ & $26^{\mathrm{b}}$ & $11^{\mathrm{a}}$ & $10^{\mathrm{a}}$ & $16^{\mathrm{b}}$ & $12^{\mathrm{a}}$ & $22^{\mathrm{a}}$ & $48^{\mathrm{a}}$ & $49^{c}$ & $32^{\mathrm{a}}$ & $15^{\mathrm{a}}$ & $42^{\mathrm{a}}$ & 1 & $10^{\mathrm{a}}$ & $19^{\mathrm{a}}$ & $61^{\mathrm{a}}$ & 1 \\
\hline $\mathrm{SOC}$ & $*$ & $98^{\mathrm{b}}$ & $15^{\mathrm{a}}$ & $16^{\mathrm{a}}$ & $10^{0} \mathrm{~b}$ & $19^{\mathrm{a}}$ & $10^{\mathrm{a}}$ & $71^{b}$ & $62^{\mathrm{c}}$ & $28^{\mathrm{a}}$ & 1 & $62^{\mathrm{a}}$ & $3^{\mathrm{a}}$ & $26^{\mathrm{a}}$ & 1 & $58^{\mathrm{a}}$ & $14^{\mathrm{a}}$ \\
\hline
\end{tabular}




\section{Appendix D: Results from the 2006 to 2009 two-step Markov chain analysis for all fish that first approached the powerhouse during the day and night periods.}

Table D1. Percentage of fish passing McNary Dam during day period in 2006 based on a two-step Markov Chain analysis.

[Data represent all fish that first approached the powerhouse during the day period. Species: YCH, Yearling Chinook salmon; STH, juvenile steelhead; SCH, subyearling Chinook salmon; SOC, Sockeye salmon. Area of Passage: PH\#1, turbine units 1-5; PH\#2, turbine units 6-10; PH\#3, turbine units 11-14; Spillway, spill bays 1-22; Service Bay, equipment service bay on the south end of powerhouse; TSW, temporary spillway weir; ( $($ ) denotes the TSW was not installed; Superscripts denote number of transitions used to calculate percentage: a, greater than 100; b , 50-100; c , 10 to 50; $(*)$, less than 10, which was insufficient sample size to calculate percentage]

\begin{tabular}{|c|c|c|c|c|c|c|c|c|c|c|c|c|c|c|c|c|c|}
\hline $\begin{array}{c}\text { Area of } \\
\text { Passage: }\end{array}$ & \multicolumn{3}{|c|}{$\mathrm{PH} \# 1$} & \multicolumn{3}{|c|}{$\mathrm{PH} \# 2$} & \multicolumn{3}{|c|}{$\mathrm{PH} \# 3$} & \multicolumn{8}{|c|}{ Spillway } \\
\hline \multirow[b]{2}{*}{ Species } & $\begin{array}{l}\text { passing } \\
\text { PH\#1 } \\
\text { after } \\
\text { coming } \\
\text { from }\end{array}$ & $\begin{array}{l}\text { passing } \\
\text { PH\#1 } \\
\text { after } \\
\text { coming } \\
\text { from }\end{array}$ & $\begin{array}{l}\text { passing } \\
\text { PH\#1 } \\
\text { after } \\
\text { coming } \\
\text { from }\end{array}$ & $\begin{array}{l}\text { passing } \\
\text { PH\#2 } \\
\text { after } \\
\text { coming } \\
\text { from }\end{array}$ & $\begin{array}{l}\text { passing } \\
\text { PH\#2 } \\
\text { after } \\
\text { coming } \\
\text { from }\end{array}$ & $\begin{array}{l}\text { passing } \\
\text { PH\#2 } \\
\text { after } \\
\text { coming } \\
\text { from }\end{array}$ & $\begin{array}{l}\text { passing } \\
\text { PH\#3 } \\
\text { after } \\
\text { coming } \\
\text { from }\end{array}$ & $\begin{array}{l}\text { passing } \\
\text { PH\#3 } \\
\text { after } \\
\text { coming } \\
\text { from }\end{array}$ & $\begin{array}{l}\text { passing } \\
\text { PH\#3 } \\
\text { after } \\
\text { coming } \\
\text { from }\end{array}$ & $\begin{array}{l}\text { passi } \\
\text { comin }\end{array}$ & $\begin{array}{l}\text { spillv } \\
\text { from }\end{array}$ & $\begin{array}{l}y \text { afte } \\
\text { H\#3 }\end{array}$ & & $\begin{array}{l}\text { passi } \\
\text { comir }\end{array}$ & $\begin{array}{l}\text { spillw } \\
\text { from } f\end{array}$ & $\begin{array}{l}\text { yy after } \\
\text { rebay }\end{array}$ & \\
\hline & & & & & & & & & & $\frac{\text { TSW }}{\underline{22}}$ & $\frac{\text { TSW }}{\underline{20}}$ & Bays & $\frac{\mathrm{TSW}}{\underline{4}}$ & $\frac{\text { TSW }}{\underline{22}}$ & $\frac{\text { TSW }}{\underline{20}}$ & Bays & $\frac{\text { TSW }}{\underline{4}}$ \\
\hline $\mathrm{YCH}$ & $16^{\mathrm{b}}$ & $24^{\mathrm{b}}$ & $8^{a}$ & $17^{\mathrm{a}}$ & $34^{\mathrm{b}}$ & $15^{\mathrm{a}}$ & $20^{\mathrm{a}}$ & $33^{\mathrm{b}}$ & $*$ & 1 & 1 & $95^{b}$ & 1 & 1 & 1 & NA & 1 \\
\hline STH & $5^{c}$ & $21^{\mathrm{c}}$ & $4^{b}$ & $8^{a}$ & $24^{\mathrm{c}}$ & $3^{\mathrm{a}}$ & $4^{\mathrm{a}}$ & $23^{c}$ & $5^{c}$ & 1 & 1 & $78^{b}$ & 1 & 1 & 1 & NA & $\backslash$ \\
\hline $\mathrm{SCH}$ & $25^{\mathrm{a}}$ & $37^{\mathrm{a}}$ & $18^{\mathrm{a}}$ & $20^{\mathrm{a}}$ & $30^{\mathrm{a}}$ & $19^{\mathrm{a}}$ & $15^{\mathrm{a}}$ & $30^{\mathrm{a}}$ & $*$ & 1 & 1 & $95^{b}$ & 1 & 1 & 1 & NA & 1 \\
\hline SOC & $*$ & $16^{\mathrm{c}}$ & $50^{c}$ & $54^{b}$ & $50^{\mathrm{c}}$ & $63^{c}$ & $56^{\mathrm{c}}$ & $56^{\mathrm{c}}$ & $*$ & 1 & 1 & $*$ & 1 & 1 & 1 & NA & 1 \\
\hline
\end{tabular}


Table D2. Percentage of fish passing McNary Dam during night period in 2006 based on a two-step Markov Chain analysis.

[Data represent all fish that first approached the powerhouse during the night period. Species: YCH, Yearling Chinook salmon; STH, juvenile steelhead; SCH, subyearling Chinook salmon; SOC, Sockeye salmon. Area of Passage: PH\#1, turbine units 1-5; PH\#2, turbine units 6-10; PH\#3, turbine units 11-14; Spillway, spill bays 1-22; Service Bay, equipment service bay on the south end of powerhouse; TSW, temporary spillway weir; ( $)$ denotes the TSW was not installed; Superscripts denote number of transitions used to calculate percentage: a, greater than $100 ; \mathrm{b}, 50-100 ; \mathrm{c}, 10$ to $50 ;(*)$, less than 10, which was insufficient sample size to calculate percentage]

\begin{tabular}{|c|c|c|c|c|c|c|c|c|c|c|c|c|c|c|c|c|c|}
\hline $\begin{array}{c}\text { Area of } \\
\text { Passage: }\end{array}$ & \multicolumn{3}{|c|}{$\mathrm{PH} \# 1$} & \multicolumn{3}{|c|}{$\mathrm{PH} \# 2$} & \multicolumn{3}{|c|}{$\mathrm{PH} \# 3$} & \multicolumn{8}{|c|}{ Spillway } \\
\hline \multirow[b]{2}{*}{ Species } & $\begin{array}{l}\text { passing } \\
\text { PH\#1 } \\
\text { after } \\
\text { coming } \\
\text { from }\end{array}$ & $\begin{array}{l}\text { passing } \\
\text { PH\#1 } \\
\text { after } \\
\text { coming } \\
\text { from }\end{array}$ & $\begin{array}{l}\text { passing } \\
\text { PH\#1 } \\
\text { after } \\
\text { coming } \\
\text { from }\end{array}$ & $\begin{array}{l}\text { passing } \\
\text { PH\#2 } \\
\text { after } \\
\text { coming } \\
\text { from }\end{array}$ & $\begin{array}{l}\text { passing } \\
\text { PH\#2 } \\
\text { after } \\
\text { coming } \\
\text { from }\end{array}$ & $\begin{array}{l}\text { passing } \\
\text { PH\#2 } \\
\text { after } \\
\text { coming } \\
\text { from }\end{array}$ & $\begin{array}{l}\text { passing } \\
\text { PH\#3 } \\
\text { after } \\
\text { coming } \\
\text { from }\end{array}$ & $\begin{array}{l}\text { passing } \\
\text { PH\#3 } \\
\text { after } \\
\text { coming } \\
\text { from }\end{array}$ & $\begin{array}{l}\text { passing } \\
\text { PH\#3 } \\
\text { after } \\
\text { coming } \\
\text { from }\end{array}$ & $\begin{array}{l}\text { passi } \\
\text { comir }\end{array}$ & $\begin{array}{l}\text { spillv } \\
\text { from }\end{array}$ & $\begin{array}{l}y \text { after } \\
\text { H\#3 }\end{array}$ & & $\begin{array}{l}\text { passi } \\
\text { comir }\end{array}$ & $\begin{array}{l}\text { g spillw } \\
\text { g from } f\end{array}$ & $\begin{array}{l}\text { yy after } \\
\text { rebay }\end{array}$ & \\
\hline & & & & & & & & & & $\frac{\text { TSW }}{\underline{22}}$ & $\frac{\text { TSW }}{\underline{20}}$ & Bays & $\frac{\text { TSW }}{\underline{4}}$ & $\frac{\text { TSW }}{\underline{22}}$ & $\frac{\text { TSW }}{\underline{20}}$ & Bays & $\frac{\text { TSW }}{\underline{4}}$ \\
\hline $\mathrm{YCH}$ & $34^{\mathrm{b}}$ & $58^{\mathrm{b}}$ & $15^{\mathrm{a}}$ & $17^{\mathrm{a}}$ & $62^{b}$ & $17^{\mathrm{b}}$ & $20^{\mathrm{b}}$ & $57^{\mathrm{b}}$ & $*$ & 1 & 1 & $96^{\mathrm{c}}$ & 1 & 1 & 1 & NA & 1 \\
\hline STH & $16^{\mathrm{b}}$ & $28^{\mathrm{b}}$ & $7^{\mathrm{a}}$ & $5^{\mathrm{a}}$ & $18^{\mathrm{b}}$ & $4^{\mathrm{a}}$ & $4^{\mathrm{a}}$ & $20^{\mathrm{b}}$ & $6^{\mathrm{b}}$ & 1 & 1 & $60^{\mathrm{a}}$ & 1 & 1 & 1 & NA & 1 \\
\hline $\mathrm{SCH}$ & $19^{\mathrm{b}}$ & $24^{\mathrm{b}}$ & $13^{\mathrm{a}}$ & $12^{\mathrm{a}}$ & $17^{\mathrm{b}}$ & $13^{\mathrm{a}}$ & $7^{\mathrm{a}}$ & $10^{\mathrm{b}}$ & $*$ & 1 & 1 & $89^{\mathrm{b}}$ & 1 & 1 & 1 & NA & 1 \\
\hline SOC & $*$ & $7^{\mathrm{c}}$ & $52^{\mathrm{c}}$ & $33^{c}$ & $40^{\mathrm{c}}$ & $8^{c}$ & $41^{\mathrm{c}}$ & $25^{\mathrm{c}}$ & $*$ & 1 & 1 & $*$ & 1 & 1 & 1 & NA & 1 \\
\hline
\end{tabular}


Table D3. Percentage of fish passing McNary Dam during day period in 2007 based on a two-step Markov Chain analysis.

[Data represent all fish that first approached the powerhouse during the day period. Species: YCH, Yearling Chinook salmon; STH, juvenile steelhead; SCH, subyearling Chinook salmon; SOC, Sockeye salmon. Area of Passage: PH\#1, turbine units 1-5; PH\#2, turbine units 6-10; PH\#3, turbine units 11-14; Spillway, spill bays 1-22; Service Bay, equipment service bay on the south end of powerhouse; TSW, temporary spillway weir; (\) denotes the TSW was not installed; Superscripts denote number of transitions used to calculate percentage: a, greater than $100 ; \mathrm{b}, 50-100 ; \mathrm{c}, 10$ to 50 ; $\left(*^{*}\right)$, less than 10, which was insufficient sample size to calculate percentage]

\begin{tabular}{|c|c|c|c|c|c|c|c|c|c|c|c|c|c|c|c|c|c|}
\hline $\begin{array}{c}\text { Area of } \\
\text { Passage: }\end{array}$ & \multicolumn{3}{|c|}{$\mathrm{PH} \# 1$} & \multicolumn{3}{|c|}{$\mathrm{PH} \# 2$} & \multicolumn{3}{|c|}{$\mathrm{PH} \# 3$} & \multicolumn{8}{|c|}{ Spillway } \\
\hline \multirow[b]{2}{*}{ Species } & $\begin{array}{l}\text { passing } \\
\mathrm{PH \# 1} \\
\text { after } \\
\text { coming } \\
\text { from }\end{array}$ & $\begin{array}{l}\text { passing } \\
\text { PH\#1 } \\
\text { after } \\
\text { coming } \\
\text { from }\end{array}$ & $\begin{array}{l}\text { passing } \\
\text { PH\#1 } \\
\text { after } \\
\text { coming } \\
\text { from }\end{array}$ & $\begin{array}{l}\text { passing } \\
\text { PH\#2 } \\
\text { after } \\
\text { coming } \\
\text { from }\end{array}$ & $\begin{array}{l}\text { passing } \\
\text { PH\#2 } \\
\text { after } \\
\text { coming } \\
\text { from }\end{array}$ & $\begin{array}{l}\text { passing } \\
\text { PH\#2 } \\
\text { after } \\
\text { coming } \\
\text { from }\end{array}$ & $\begin{array}{l}\text { passing } \\
\mathrm{PH \# 3} \\
\text { after } \\
\text { coming } \\
\text { from }\end{array}$ & $\begin{array}{l}\text { passing } \\
\text { PH\#3 } \\
\text { after } \\
\text { coming } \\
\text { from }\end{array}$ & $\begin{array}{l}\text { passing } \\
\text { PH\#3 } \\
\text { after } \\
\text { coming } \\
\text { from }\end{array}$ & $\begin{array}{l}\text { passi } \\
\text { comir }\end{array}$ & $\begin{array}{l}\text { spillu } \\
\text { from }\end{array}$ & $\begin{array}{l}y \text { after } \\
-\# 3\end{array}$ & & $\begin{array}{l}\text { passi } \\
\text { comir }\end{array}$ & $\begin{array}{l}\text { g spillu } \\
\text { from }\end{array}$ & $\begin{array}{l}\text { y after } \\
\text { rebay }\end{array}$ & \\
\hline & & & & & & & & & & $\frac{\text { TSW }}{\underline{22}}$ & $\frac{\text { TSW }}{\underline{20}}$ & Bays & $\frac{\text { TSW }}{\underline{4}}$ & $\frac{\text { TSW }}{\underline{22}}$ & $\frac{\text { TSW }}{\underline{20}}$ & Bays & $\frac{\text { TSW }}{\underline{4}}$ \\
\hline $\mathrm{YCH}$ & $21^{\mathrm{b}}$ & $29^{\mathrm{a}}$ & $17^{\mathrm{a}}$ & $25^{\mathrm{a}}$ & $39^{\mathrm{a}}$ & $24^{\mathrm{a}}$ & $9^{\mathrm{a}}$ & $32^{\mathrm{a}}$ & $*$ & $78^{\mathrm{a}}$ & $9^{\mathrm{a}}$ & $11^{\mathrm{a}}$ & 1 & NA & NA & NA & 1 \\
\hline STH & $3^{a}$ & $3^{a}$ & $4^{a}$ & $3^{a}$ & $3^{a}$ & $1^{\mathrm{a}}$ & $1^{\mathrm{a}}$ & $2^{a}$ & $0^{c}$ & $77^{\mathrm{a}}$ & $11^{\mathrm{a}}$ & $3^{a}$ & 1 & NA & NA & NA & 1 \\
\hline $\mathrm{SCH}$ & $25^{\mathrm{a}}$ & $35^{\mathrm{a}}$ & $24^{\mathrm{a}}$ & $26^{\mathrm{a}}$ & $28^{\mathrm{a}}$ & $29^{\mathrm{b}}$ & $16^{\mathrm{a}}$ & $18^{\mathrm{a}}$ & $17^{\mathrm{c}}$ & $63^{\mathrm{a}}$ & $12^{\mathrm{a}}$ & $15^{\mathrm{a}}$ & 1 & NA & NA & NA & 1 \\
\hline SOC & $38^{\mathrm{c}}$ & $34^{\mathrm{b}}$ & $32^{\mathrm{b}}$ & $31^{\mathrm{b}}$ & $42^{\mathrm{b}}$ & $46^{\mathrm{b}}$ & $21^{\mathrm{c}}$ & $15^{\mathrm{c}}$ & $*$ & $50^{\mathrm{c}}$ & $10^{\mathrm{c}}$ & $20^{\mathrm{c}}$ & 1 & NA & NA & NA & 1 \\
\hline
\end{tabular}


Table D4. Percentage of fish passing McNary Dam during night period in 2007 based on a two-step Markov Chain analysis.

[Data represent all fish that first approached the powerhouse during the night period. Species: YCH, Yearling Chinook salmon; STH, juvenile steelhead; SCH, subyearling Chinook salmon; SOC, Sockeye salmon. Area of Passage: PH\#1, turbine units 1-5; PH\#2, turbine units 6-10; PH\#3, turbine units 11-14; Spillway, spill bays 1-22; Service Bay, equipment service bay on the south end of powerhouse; TSW, temporary spillway weir; ( $)$ denotes the TSW was not installed; Superscripts denote number of transitions used to calculate percentage: a, greater than $100 ; \mathrm{b}, 50-100 ; \mathrm{c}, 10$ to $50 ;(*)$, less than 10, which was insufficient sample size to calculate percentage]

\begin{tabular}{|c|c|c|c|c|c|c|c|c|c|c|c|c|c|c|c|c|c|}
\hline $\begin{array}{c}\text { Area of } \\
\text { Passage } \\
\end{array}$ & \multicolumn{3}{|c|}{$\mathrm{PH} \# 1$} & \multicolumn{3}{|c|}{$\mathrm{PH} \# 2$} & \multicolumn{3}{|c|}{$\mathrm{PH} \# 3$} & \multicolumn{8}{|c|}{ Spillway } \\
\hline \multirow[b]{2}{*}{ Species } & $\begin{array}{l}\text { passing } \\
\text { PH\#1 } \\
\text { after } \\
\text { coming } \\
\text { from }\end{array}$ & $\begin{array}{l}\text { passing } \\
\text { PH\#1 } \\
\text { after } \\
\text { coming } \\
\text { from }\end{array}$ & $\begin{array}{l}\text { passing } \\
\text { PH\#1 } \\
\text { after } \\
\text { coming } \\
\text { from }\end{array}$ & $\begin{array}{l}\text { passing } \\
\mathrm{PH \# 2} \\
\text { after } \\
\text { coming } \\
\text { from }\end{array}$ & $\begin{array}{l}\text { passing } \\
\text { PH\#2 } \\
\text { after } \\
\text { coming } \\
\text { from }\end{array}$ & $\begin{array}{l}\text { passing } \\
\text { PH\#2 } \\
\text { after } \\
\text { coming } \\
\text { from }\end{array}$ & $\begin{array}{l}\text { passing } \\
\text { PH\#3 } \\
\text { after } \\
\text { coming } \\
\text { from }\end{array}$ & $\begin{array}{l}\text { passing } \\
\text { PH\#3 } \\
\text { after } \\
\text { coming } \\
\text { from }\end{array}$ & $\begin{array}{l}\text { passing } \\
\text { PH\#3 } \\
\text { after } \\
\text { coming } \\
\text { from }\end{array}$ & $\begin{array}{l}\text { passi } \\
\text { comir }\end{array}$ & $\begin{array}{l}\text { spillv } \\
\text { from }\end{array}$ & $\begin{array}{l}y \text { afte } \\
\text { H\#3 }\end{array}$ & & $\begin{array}{l}\text { passi } \\
\text { comir }\end{array}$ & $\begin{array}{l}\text { g spillu } \\
\text { g from } \mathrm{f}\end{array}$ & $\begin{array}{l}\text { yy after } \\
\text { rebay }\end{array}$ & \\
\hline & & & & & & & & & & $\frac{\text { TSW }}{\underline{22}}$ & $\frac{\text { TSW }}{\underline{20}}$ & Bays & $\frac{\text { TSW }}{\underline{4}}$ & $\frac{\text { TSW }}{\underline{22}}$ & $\frac{\text { TSW }}{\underline{20}}$ & Bays & $\frac{\mathrm{TSW}}{\underline{4}}$ \\
\hline $\mathrm{YCH}$ & $29^{c}$ & $39^{b}$ & $15^{\mathrm{a}}$ & $22^{\mathrm{a}}$ & $28^{\mathrm{b}}$ & $29^{\mathrm{b}}$ & $10^{\mathrm{a}}$ & $26^{\mathrm{b}}$ & $*$ & $78^{\mathrm{b}}$ & $5^{\mathrm{b}}$ & $16^{\mathrm{b}}$ & 1 & NA & NA & NA & 1 \\
\hline STH & $13^{\mathrm{a}}$ & $14^{\mathrm{b}}$ & $5^{\mathrm{a}}$ & $4^{\mathrm{a}}$ & $9^{b}$ & $8^{\mathrm{a}}$ & $5^{\mathrm{a}}$ & $17^{\mathrm{b}}$ & $7^{\mathrm{c}}$ & $49^{\mathrm{a}}$ & $16^{\mathrm{a}}$ & $16^{\mathrm{a}}$ & 1 & NA & NA & NA & 1 \\
\hline $\mathrm{SCH}$ & $15^{\mathrm{b}}$ & $28^{\mathrm{b}}$ & $8^{\mathrm{a}}$ & $11^{\mathrm{a}}$ & $25^{\mathrm{b}}$ & $12^{\mathrm{b}}$ & $9^{a}$ & $10^{\mathrm{b}}$ & $*$ & $48^{\mathrm{b}}$ & $16^{\mathrm{b}}$ & $27^{\mathrm{b}}$ & 1 & NA & NA & NA & 1 \\
\hline SOC & $37^{\mathrm{c}}$ & $44^{\mathrm{b}}$ & $33^{c}$ & $34^{\mathrm{b}}$ & $38^{\mathrm{c}}$ & $49^{c}$ & $19^{c}$ & $15^{\mathrm{c}}$ & $*$ & $56^{\mathrm{c}}$ & $25^{\mathrm{c}}$ & $6^{\mathrm{c}}$ & 1 & NA & NA & NA & 1 \\
\hline
\end{tabular}


Table D5. Percentage of fish passing McNary Dam during day period in 2008 based on a two-step Markov Chain analysis.

[Data represent all fish that first approached the powerhouse during the day period. Species: YCH, Yearling Chinook salmon; STH, juvenile steelhead; SCH, subyearling Chinook salmon; SOC, Sockeye salmon. Area of Passage: PH\#1, turbine units 1-5; PH\#2, turbine units 6-10; PH\#3, turbine units 11-14; Spillway, spill bays 1-22; Service Bay, equipment service bay on the south end of powerhouse; TSW, temporary spillway weir; (\) denotes the TSW was not installed; Superscripts denote number of transitions used to calculate percentage: a, greater than $100 ; \mathrm{b}, 50-100 ; \mathrm{c}, 10$ to 50 ; $\left(*^{*}\right)$, less than 10, which was insufficient sample size to calculate percentage]

\begin{tabular}{|c|c|c|c|c|c|c|c|c|c|c|c|c|c|c|c|c|c|}
\hline $\begin{array}{c}\text { Area of } \\
\text { Passage: }\end{array}$ & \multicolumn{3}{|c|}{$\mathrm{PH} \# 1$} & \multicolumn{3}{|c|}{$\mathrm{PH} \# 2$} & \multicolumn{3}{|c|}{$\mathrm{PH} \# 3$} & \multicolumn{8}{|c|}{ Spillway } \\
\hline \multirow[b]{2}{*}{ Species } & $\begin{array}{l}\text { passing } \\
\mathrm{PH \# 1} \\
\text { after } \\
\text { coming } \\
\text { from }\end{array}$ & $\begin{array}{l}\text { passing } \\
\text { PH\#1 } \\
\text { after } \\
\text { coming } \\
\text { from }\end{array}$ & $\begin{array}{l}\text { passing } \\
\text { PH\#1 } \\
\text { after } \\
\text { coming } \\
\text { from }\end{array}$ & $\begin{array}{l}\text { passing } \\
\text { PH\#2 } \\
\text { after } \\
\text { coming } \\
\text { from }\end{array}$ & $\begin{array}{l}\text { passing } \\
\text { PH\#2 } \\
\text { after } \\
\text { coming } \\
\text { from }\end{array}$ & $\begin{array}{l}\text { passing } \\
\text { PH\#2 } \\
\text { after } \\
\text { coming } \\
\text { from }\end{array}$ & $\begin{array}{l}\text { passing } \\
\mathrm{PH \# 3} \\
\text { after } \\
\text { coming } \\
\text { from }\end{array}$ & $\begin{array}{l}\text { passing } \\
\text { PH\#3 } \\
\text { after } \\
\text { coming } \\
\text { from }\end{array}$ & $\begin{array}{l}\text { passing } \\
\text { PH\#3 } \\
\text { after } \\
\text { coming } \\
\text { from }\end{array}$ & $\begin{array}{l}\text { passi } \\
\text { comir }\end{array}$ & $\begin{array}{l}\text { spillu } \\
\text { from }\end{array}$ & $\begin{array}{l}y \text { after } \\
-\# 3\end{array}$ & & $\begin{array}{l}\text { passi } \\
\text { comir }\end{array}$ & $\begin{array}{l}\text { g spillu } \\
\text { from }\end{array}$ & $\begin{array}{l}\text { y after } \\
\text { rebay }\end{array}$ & \\
\hline & & & & & & & & & & $\frac{\text { TSW }}{\underline{20}}$ & $\frac{\text { TSW }}{\underline{19}}$ & Bays & $\frac{\text { TSW }}{\underline{4}}$ & $\frac{\text { TSW }}{\underline{20}}$ & $\frac{\text { TSW }}{\underline{19}}$ & Bays & $\frac{\text { TSW }}{\underline{4}}$ \\
\hline $\mathrm{YCH}$ & $19^{c}$ & $13^{c}$ & $18^{\mathrm{b}}$ & $22^{\mathrm{b}}$ & $31^{\mathrm{c}}$ & $22^{c}$ & $25^{\mathrm{b}}$ & $15^{\mathrm{c}}$ & $*$ & $36^{\mathrm{b}}$ & $16^{\mathrm{b}}$ & $43^{b}$ & 1 & NA & NA & NA & 1 \\
\hline STH & $3^{c}$ & $11^{\mathrm{c}}$ & $7^{\mathrm{b}}$ & $4^{a}$ & $0^{c}$ & $8^{c}$ & $7^{\mathrm{a}}$ & $3^{b}$ & $26^{\mathrm{c}}$ & $46^{\mathrm{a}}$ & $19^{\mathrm{a}}$ & $17^{\mathrm{a}}$ & 1 & NA & NA & NA & 1 \\
\hline $\mathrm{SCH}$ & $15^{\mathrm{a}}$ & $31^{\mathrm{a}}$ & $21^{\mathrm{a}}$ & $20^{\mathrm{a}}$ & $25^{\mathrm{b}}$ & $3^{c}$ & $16^{\mathrm{a}}$ & $13^{\mathrm{c}}$ & $18^{\mathrm{c}}$ & $19^{\mathrm{a}}$ & $14^{\mathrm{a}}$ & $58^{\mathrm{a}}$ & 1 & NA & NA & NA & 1 \\
\hline SOC & $*$ & $36^{\mathrm{c}}$ & $*$ & $88^{c}$ & $81^{\mathrm{c}}$ & $*$ & $*$ & $33^{\mathrm{c}}$ & $*$ & $*$ & $*$ & $*$ & 1 & NA & NA & NA & 1 \\
\hline
\end{tabular}


Table D6. Percentage of fish passing McNary Dam during night period in 2008 based on a two-step Markov Chain analysis.

[Data represent all fish that first approached the powerhouse during the night period. Species: YCH, Yearling Chinook salmon; STH, juvenile steelhead; SCH, subyearling Chinook salmon; SOC, Sockeye salmon. Area of Passage: PH\#1, turbine units 1-5; PH\#2, turbine units 6-10; PH\#3, turbine units 11-14; Spillway, spill bays 1-22; Service Bay, equipment service bay on the south end of powerhouse; TSW, temporary spillway weir; ( $)$ denotes the TSW was not installed; Superscripts denote number of transitions used to calculate percentage: a, greater than $100 ; \mathrm{b}, 50-100 ; \mathrm{c}, 10$ to $50 ;(*)$, less than 10, which was insufficient sample size to calculate percentage]

\begin{tabular}{|c|c|c|c|c|c|c|c|c|c|c|c|c|c|c|c|c|c|}
\hline $\begin{array}{c}\text { Area of } \\
\text { Passage: }\end{array}$ & \multicolumn{3}{|c|}{$\mathrm{PH} \# 1$} & \multicolumn{3}{|c|}{$\mathrm{PH} \# 2$} & \multicolumn{3}{|c|}{$\mathrm{PH} \# 3$} & \multicolumn{8}{|c|}{ Spillway } \\
\hline \multirow[b]{2}{*}{ Species } & $\begin{array}{l}\text { passing } \\
\text { PH\#1 } \\
\text { after } \\
\text { coming } \\
\text { from }\end{array}$ & $\begin{array}{l}\text { passing } \\
\text { PH\#1 } \\
\text { after } \\
\text { coming } \\
\text { from }\end{array}$ & $\begin{array}{l}\text { passing } \\
\text { PH\#1 } \\
\text { after } \\
\text { coming } \\
\text { from }\end{array}$ & $\begin{array}{l}\text { passing } \\
\mathrm{PH \# 2} \\
\text { after } \\
\text { coming } \\
\text { from }\end{array}$ & $\begin{array}{l}\text { passing } \\
\text { PH\#2 } \\
\text { after } \\
\text { coming } \\
\text { from }\end{array}$ & $\begin{array}{l}\text { passing } \\
\text { PH\#2 } \\
\text { after } \\
\text { coming } \\
\text { from }\end{array}$ & $\begin{array}{l}\text { passing } \\
\text { PH\#3 } \\
\text { after } \\
\text { coming } \\
\text { from }\end{array}$ & $\begin{array}{l}\text { passing } \\
\text { PH\#3 } \\
\text { after } \\
\text { coming } \\
\text { from }\end{array}$ & $\begin{array}{l}\text { passing } \\
\text { PH\#3 } \\
\text { after } \\
\text { coming } \\
\text { from }\end{array}$ & $\begin{array}{l}\text { passi } \\
\text { comir }\end{array}$ & $\begin{array}{l}\text { spillv } \\
\text { from }\end{array}$ & $\begin{array}{l}y \text { afte } \\
\text { H\#3 }\end{array}$ & & $\begin{array}{l}\text { passi } \\
\text { comir }\end{array}$ & $\begin{array}{l}\text { g spillu } \\
\text { g from } \mathrm{f}\end{array}$ & $\begin{array}{l}\text { yy after } \\
\text { rebay }\end{array}$ & \\
\hline & & & & & & & & & & $\frac{\text { TSW }}{\underline{20}}$ & $\frac{\text { TSW }}{\underline{19}}$ & Bays & $\frac{\text { TSW }}{\underline{4}}$ & $\frac{\text { TSW }}{\underline{20}}$ & $\frac{\text { TSW }}{\underline{19}}$ & Bays & $\frac{\mathrm{TSW}}{\underline{4}}$ \\
\hline $\mathrm{YCH}$ & $20^{c}$ & $37^{\mathrm{c}}$ & $19^{c}$ & $14^{\mathrm{b}}$ & $16^{\mathrm{c}}$ & $22^{c}$ & $16^{\mathrm{c}}$ & $15^{\mathrm{c}}$ & $40^{\mathrm{c}}$ & $35^{\mathrm{c}}$ & $16^{\mathrm{c}}$ & $26^{\mathrm{c}}$ & 1 & NA & NA & NA & 1 \\
\hline STH & $11^{\mathrm{b}}$ & $29^{b}$ & $13^{\mathrm{a}}$ & $17^{\mathrm{a}}$ & $4^{\mathrm{c}}$ & $5^{b}$ & $7^{\mathrm{a}}$ & $12^{\mathrm{b}}$ & $23^{\mathrm{c}}$ & $31^{\mathrm{a}}$ & $10^{\mathrm{a}}$ & $27^{\mathrm{a}}$ & 1 & NA & NA & NA & 1 \\
\hline $\mathrm{SCH}$ & $23^{b}$ & $31^{\mathrm{b}}$ & $20^{\mathrm{b}}$ & $13^{b}$ & $12^{\mathrm{c}}$ & $8^{c}$ & $12^{\mathrm{b}}$ & $14^{\mathrm{c}}$ & $*$ & $26^{\mathrm{c}}$ & $21^{\mathrm{c}}$ & $33^{\mathrm{c}}$ & 1 & NA & NA & NA & 1 \\
\hline SOC & $*$ & $*$ & $*$ & $*$ & $*$ & $*$ & $*$ & $*$ & $*$ & $*$ & $*$ & $*$ & 1 & NA & NA & NA & 1 \\
\hline
\end{tabular}


Table D7. Percentage of fish passing McNary Dam during day period in 2009 based on a two-step Markov Chain analysis.

[Data represent all fish that first approached the powerhouse during the day period. Species: YCH, Yearling Chinook salmon; STH, juvenile steelhead; $\mathrm{SCH}$, subyearling Chinook salmon; SOC, Sockeye salmon. Area of Passage: PH\#1, turbine units 1-5; PH\#2, turbine units 6-10; PH\#3, turbine units 11-14; Spillway, spill bays 1-22; Service Bay, equipment service bay on the south end of powerhouse; TSW, temporary spillway weir; ( () denotes the TSW was not installed; Superscripts denote number of transitions used to calculate percentage: a, greater than $100 ; \mathrm{b}, 50-100 ; \mathrm{c}, 10$ to $50 ;(*)$, less than 10 , which was insufficient sample size to calculate percentage]

\begin{tabular}{|c|c|c|c|c|c|c|c|c|c|c|c|c|c|c|c|c|c|}
\hline $\begin{array}{c}\text { Area of } \\
\text { Passage: }\end{array}$ & \multicolumn{3}{|c|}{$\mathrm{PH} \# 1$} & \multicolumn{3}{|c|}{$\mathrm{PH} \# 2$} & \multicolumn{3}{|c|}{$\mathrm{PH} \# 3$} & \multicolumn{8}{|c|}{ Spillway } \\
\hline \multirow[b]{2}{*}{ Species } & $\begin{array}{l}\text { passing } \\
\text { PH\#1 } \\
\text { after } \\
\text { coming } \\
\text { from }\end{array}$ & $\begin{array}{l}\text { passing } \\
\text { PH\#1 } \\
\text { after } \\
\text { coming } \\
\text { from }\end{array}$ & $\begin{array}{l}\text { passing } \\
\text { PH\#1 } \\
\text { after } \\
\text { coming } \\
\text { from }\end{array}$ & $\begin{array}{l}\text { passing } \\
\text { PH\#2 } \\
\text { after } \\
\text { coming } \\
\text { from }\end{array}$ & $\begin{array}{l}\text { passing } \\
\text { PH\#2 } \\
\text { after } \\
\text { coming } \\
\text { from }\end{array}$ & $\begin{array}{l}\text { passing } \\
\text { PH\#2 } \\
\text { after } \\
\text { coming } \\
\text { from }\end{array}$ & $\begin{array}{l}\text { passing } \\
\text { PH\#3 } \\
\text { after } \\
\text { coming } \\
\text { from }\end{array}$ & $\begin{array}{l}\text { passing } \\
\text { PH\#3 } \\
\text { after } \\
\text { coming } \\
\text { from }\end{array}$ & $\begin{array}{l}\text { passing } \\
\text { PH\#3 } \\
\text { after } \\
\text { coming } \\
\text { from }\end{array}$ & $\begin{array}{l}\text { passi } \\
\text { comir }\end{array}$ & $\begin{array}{l}\text { spillw } \\
\text { from } F\end{array}$ & $\begin{array}{l}y \text { afte } \\
-\# 33\end{array}$ & & $\begin{array}{l}\text { pass } \\
\text { comi }\end{array}$ & $\begin{array}{l}\text { g spillu } \\
\text { from }\end{array}$ & $\begin{array}{l}\text { y after } \\
\text { rebay }\end{array}$ & \\
\hline & & & & & & & & & & $\frac{\text { TSW }}{\underline{20}}$ & $\frac{\text { TSW }}{\underline{19}}$ & Bays & $\frac{\text { TSW }}{\underline{4}}$ & $\frac{\text { TSW }}{\underline{20}}$ & $\frac{\text { TSW }}{\underline{19}}$ & Bays & $\frac{\text { TSW }}{\underline{4}}$ \\
\hline $\mathrm{YCH}$ & $22^{\mathrm{a}}$ & $22^{\mathrm{a}}$ & $19^{\mathrm{a}}$ & $14^{\mathrm{a}}$ & $24^{\mathrm{a}}$ & $12^{\mathrm{a}}$ & $24^{\mathrm{a}}$ & $38^{\mathrm{a}}$ & $*$ & $20^{\mathrm{a}}$ & 1 & $69^{a}$ & $4^{\mathrm{a}}$ & NA & 1 & NA & NA \\
\hline STH & $9^{b}$ & $4^{b}$ & $8^{a}$ & $8^{\mathrm{a}}$ & $14^{\mathrm{b}}$ & $5^{\mathrm{a}}$ & $5^{\mathrm{a}}$ & $6^{\mathrm{b}}$ & $6^{\mathrm{c}}$ & $49^{\mathrm{a}}$ & 1 & $27^{\mathrm{a}}$ & $7^{\mathrm{a}}$ & NA & 1 & NA & NA \\
\hline $\mathrm{SCH}$ & $16^{\mathrm{a}}$ & $28^{\mathrm{b}}$ & $13^{\mathrm{a}}$ & $8^{\mathrm{a}}$ & $17^{\mathrm{a}}$ & $11^{\mathrm{a}}$ & $22^{\mathrm{a}}$ & $41^{\mathrm{a}}$ & $21^{\mathrm{c}}$ & $33^{\mathrm{a}}$ & $6^{\mathrm{a}}$ & $54^{\mathrm{a}}$ & 1 & NA & NA & NA & 1 \\
\hline SOC & $*$ & $94^{\mathrm{b}}$ & $11^{\mathrm{a}}$ & $17^{\mathrm{a}}$ & $92^{\mathrm{b}}$ & $24^{\mathrm{a}}$ & $14^{\mathrm{a}}$ & $58^{\mathrm{b}}$ & $55^{\mathrm{c}}$ & $30^{\mathrm{a}}$ & 1 & $66^{\mathrm{a}}$ & $1^{\mathrm{a}}$ & NA & 1 & NA & NA \\
\hline
\end{tabular}


Table D8. Percentage of fish passing McNary Dam during night period in 2009 based on a two-step Markov Chain analysis.

[Data represent all fish that first approached the powerhouse during the night period. Species: YCH, Yearling Chinook salmon; STH, juvenile steelhead; SCH, subyearling Chinook salmon; SOC, Sockeye salmon. Area of Passage: PH\#1, turbine units 1-5; PH\#2, turbine units 6-10; PH\#3, turbine units 11-14; Spillway, spill bays 1-22; Service Bay, equipment service bay on the south end of powerhouse; TSW, temporary spillway weir; ( () denotes the TSW was not installed; Superscripts denote number of transitions used to calculate percentage: a, greater than $100 ; \mathrm{b}, 50-100 ; \mathrm{c}, 10$ to $50 ;(*)$, less than 10, which was insufficient sample size to calculate percentage]

\begin{tabular}{|c|c|c|c|c|c|c|c|c|c|c|c|c|c|c|c|c|c|}
\hline $\begin{array}{c}\text { Area of } \\
\text { Passage: }\end{array}$ & \multicolumn{3}{|c|}{$\mathrm{PH} \# 1$} & \multicolumn{3}{|c|}{$\mathrm{PH} \# 2$} & \multicolumn{3}{|c|}{$\mathrm{PH} \# 3$} & \multicolumn{8}{|c|}{ Spillway } \\
\hline \multirow[b]{2}{*}{ Species } & $\begin{array}{l}\text { passing } \\
\text { PH\#1 } \\
\text { after } \\
\text { coming } \\
\text { from }\end{array}$ & $\begin{array}{l}\text { passing } \\
\text { PH\#1 } \\
\text { after } \\
\text { coming } \\
\text { from }\end{array}$ & $\begin{array}{l}\text { passing } \\
\text { PH\#1 } \\
\text { after } \\
\text { coming } \\
\text { from }\end{array}$ & $\begin{array}{l}\text { passing } \\
\text { PH\#2 } \\
\text { after } \\
\text { coming } \\
\text { from }\end{array}$ & $\begin{array}{l}\text { passing } \\
\text { PH\#2 } \\
\text { after } \\
\text { coming } \\
\text { from }\end{array}$ & $\begin{array}{l}\text { passing } \\
\text { PH\#2 } \\
\text { after } \\
\text { coming } \\
\text { from }\end{array}$ & $\begin{array}{l}\text { passing } \\
\text { PH\#3 } \\
\text { after } \\
\text { coming } \\
\text { from }\end{array}$ & $\begin{array}{l}\text { passing } \\
\text { PH\#3 } \\
\text { after } \\
\text { coming } \\
\text { from }\end{array}$ & $\begin{array}{l}\text { passing } \\
\text { PH\#3 } \\
\text { after } \\
\text { coming } \\
\text { from }\end{array}$ & $\begin{array}{l}\text { passi } \\
\text { comir }\end{array}$ & $\begin{array}{l}\text { spillw } \\
\text { from } F\end{array}$ & $\begin{array}{l}y \text { afte } \\
-\# 33\end{array}$ & & $\begin{array}{l}\text { pass } \\
\text { comi }\end{array}$ & $\begin{array}{l}\text { g spilly } \\
\text { from }\end{array}$ & $\begin{array}{l}\text { y after } \\
\text { rebay }\end{array}$ & \\
\hline & & & & & & & & & & $\frac{\text { TSW }}{\underline{20}}$ & $\frac{\text { TSW }}{\underline{19}}$ & Bays & $\frac{\text { TSW }}{\underline{4}}$ & $\frac{\text { TSW }}{\underline{20}}$ & $\frac{\text { TSW }}{\underline{19}}$ & Bays & $\frac{\text { TSW }}{\underline{4}}$ \\
\hline $\mathrm{YCH}$ & $22^{\mathrm{b}}$ & $34^{\mathrm{b}}$ & $9^{a}$ & $13^{\mathrm{a}}$ & $39^{\mathrm{b}}$ & $13^{\mathrm{a}}$ & $15^{\mathrm{a}}$ & $42^{\mathrm{b}}$ & $*$ & $26^{\mathrm{b}}$ & 1 & $57^{b}$ & $3^{b}$ & NA & 1 & NA & NA \\
\hline STH & $11^{\mathrm{a}}$ & $16^{\mathrm{a}}$ & $11^{\mathrm{a}}$ & $6^{\mathrm{a}}$ & $21^{\mathrm{b}}$ & $8^{a}$ & $7^{\mathrm{a}}$ & $22^{\mathrm{b}}$ & $4^{b}$ & $26^{\mathrm{a}}$ & 1 & $39^{a}$ & $9^{a}$ & NA & 1 & NA & NA \\
\hline $\mathrm{SCH}$ & $13^{\mathrm{a}}$ & $26^{\mathrm{b}}$ & $12^{\mathrm{a}}$ & $9^{a}$ & $16^{\mathrm{b}}$ & $12^{\mathrm{a}}$ & $21^{\mathrm{a}}$ & $48^{\mathrm{a}}$ & $41^{\mathrm{c}}$ & $34^{\mathrm{a}}$ & $13^{\mathrm{a}}$ & $43^{\mathrm{a}}$ & 1 & NA & NA & NA & 1 \\
\hline SOC & $*$ & $98^{\mathrm{b}}$ & $14^{\mathrm{a}}$ & $15^{\mathrm{a}}$ & $10^{\circ} \mathrm{b}$ & $19^{\mathrm{a}}$ & $10^{\mathrm{a}}$ & $71^{\mathrm{b}}$ & $43^{c}$ & $28^{\mathrm{a}}$ & 1 & $62^{\mathrm{a}}$ & $3^{\mathrm{a}}$ & NA & 1 & NA & NA \\
\hline
\end{tabular}




\section{Appendix E: Results from the 2006 to 2009 two-step Markov chain analysis for all fish that first approached the spillway during the day and night periods.}

Table E1. Percentage of fish passing McNary Dam during day period in 2006 based on a two-step Markov Chain analysis.

[Data represent all fish that first approached the spillway during the day period. Species: YCH, Yearling Chinook salmon; STH, juvenile steelhead; SCH, subyearling Chinook salmon; SOC, Sockeye salmon. Area of Passage: PH\#1, turbine units 1-5; PH\#2, turbine units 6-10; PH\#3, turbine units 11-14; Spillway, spill bays 1-22; Service Bay, equipment service bay on the south end of powerhouse; TSW, temporary spillway weir; ( $($ ) denotes the TSW was not installed; Superscripts denote number of transitions used to calculate percentage: a, greater than 100; b , 50-100; c , 10 to 50; (*), less than 10, which was insufficient sample size to calculate percentage]

\begin{tabular}{|c|c|c|c|c|c|c|c|c|c|c|c|c|c|c|c|c|c|}
\hline $\begin{array}{c}\text { Area of } \\
\text { Passage: }\end{array}$ & \multicolumn{3}{|c|}{$\mathrm{PH} \# 1$} & \multicolumn{3}{|c|}{$\mathrm{PH} \# 2$} & \multicolumn{3}{|c|}{$\mathrm{PH} \# 3$} & \multicolumn{8}{|c|}{ Spillway } \\
\hline \multirow[b]{2}{*}{$\underline{\text { Species }}$} & $\begin{array}{l}\text { passing } \\
\text { PH\#1 } \\
\text { after } \\
\text { coming } \\
\text { from }\end{array}$ & $\begin{array}{l}\text { passing } \\
\text { PH\#1 } \\
\text { after } \\
\text { coming } \\
\text { from }\end{array}$ & $\begin{array}{l}\text { passing } \\
\text { PH\#1 } \\
\text { after } \\
\text { coming } \\
\text { from }\end{array}$ & $\begin{array}{l}\text { passing } \\
\mathrm{PH \# 2} \\
\text { after } \\
\text { coming } \\
\text { from }\end{array}$ & $\begin{array}{l}\text { passing } \\
\text { PH\#2 } \\
\text { after } \\
\text { coming } \\
\text { from }\end{array}$ & $\begin{array}{l}\text { passing } \\
\text { PH\#2 } \\
\text { after } \\
\text { coming } \\
\text { from }\end{array}$ & $\begin{array}{l}\text { passing } \\
\mathrm{PH \# 3} \\
\text { after } \\
\text { coming } \\
\text { from }\end{array}$ & $\begin{array}{l}\text { passing } \\
\text { PH\#3 } \\
\text { after } \\
\text { coming } \\
\text { from }\end{array}$ & $\begin{array}{l}\text { passing } \\
\text { PH\#3 } \\
\text { after } \\
\text { coming } \\
\text { from }\end{array}$ & $\begin{array}{l}\text { passi } \\
\text { comir }\end{array}$ & $\begin{array}{l}\text { spil } \\
\text { from }\end{array}$ & $\begin{array}{l}\text { ay afte } \\
\mathrm{H} \# 3\end{array}$ & & $\begin{array}{l}\text { passi } \\
\text { comir }\end{array}$ & $\begin{array}{l}g \text { spillu } \\
\text { g from }\end{array}$ & $\begin{array}{l}\text { y after } \\
\text { rebay }\end{array}$ & \\
\hline & & & & & & & & & & $\frac{\text { TSW }}{\underline{22}}$ & $\frac{\text { TSV }}{\underline{20}}$ & Bays & $\frac{\text { TSW }}{\underline{4}}$ & $\frac{\text { TSW }}{\underline{22}}$ & $\frac{\text { TSW }}{\underline{20}}$ & Bays & $\frac{\text { TSW }}{\underline{4}}$ \\
\hline $\mathrm{YCH}$ & $*$ & NA & $*$ & $*$ & NA & $36^{\mathrm{c}}$ & $*$ & NA & $*$ & 1 & 1 & $*$ & 1 & 1 & 1 & $94^{\mathrm{a}}$ & 1 \\
\hline STH & $*$ & NA & $14^{\mathrm{c}}$ & $0^{\mathrm{c}}$ & NA & $10^{\mathrm{c}}$ & $0^{\mathrm{c}}$ & NA & $5^{c}$ & 1 & 1 & $60^{c}$ & 1 & 1 & 1 & $73^{b}$ & 1 \\
\hline $\mathrm{SCH}$ & $*$ & NA & $20^{c}$ & $5^{c}$ & NA & $6^{c}$ & $4^{c}$ & NA & $4^{c}$ & 1 & 1 & $92^{c}$ & 1 & 1 & 1 & $41^{c}$ & 1 \\
\hline SOC & $*$ & NA & $*$ & $*$ & NA & $*$ & $*$ & NA & $*$ & 1 & 1 & $*$ & 1 & 1 & 1 & $*$ & 1 \\
\hline
\end{tabular}


Table E2. Percentage of fish passing McNary Dam during night period in 2006 based on a two-step Markov Chain analysis.

[Data represent all fish that first approached the spillway during the night period. Species: YCH, Yearling Chinook salmon; STH, juvenile steelhead; SCH, subyearling Chinook salmon; SOC, Sockeye salmon. Area of Passage: PH\#1, turbine units 1-5; PH\#2, turbine units 6-10; PH\#3, turbine units 11-14;

Spillway, spill bays 1-22; Service Bay, equipment service bay on the south end of powerhouse; TSW, temporary spillway weir; ( () denotes the TSW was not installed; Superscripts denote number of transitions used to calculate percentage: a, greater than $100 ; \mathrm{b}, 50-100 ; \mathrm{c}, 10$ to 50 ; $(*)$, less than 10, which was insufficient sample size to calculate percentage]

\begin{tabular}{|c|c|c|c|c|c|c|c|c|c|c|c|c|c|c|c|c|c|}
\hline $\begin{array}{c}\text { Area of } \\
\text { Passage: }\end{array}$ & \multicolumn{3}{|c|}{$\mathrm{PH} \# 1$} & \multicolumn{3}{|c|}{$\mathrm{PH} \# 2$} & \multicolumn{3}{|c|}{$\mathrm{PH} \# 3$} & \multicolumn{8}{|c|}{ Spillway } \\
\hline \multirow[b]{2}{*}{ Species } & $\begin{array}{l}\text { passing } \\
\text { PH\#1 } \\
\text { after } \\
\text { coming } \\
\text { from }\end{array}$ & $\begin{array}{l}\text { passing } \\
\text { PH\#1 } \\
\text { after } \\
\text { coming } \\
\text { from }\end{array}$ & $\begin{array}{l}\text { passing } \\
\text { PH\#1 } \\
\text { after } \\
\text { coming } \\
\text { from }\end{array}$ & $\begin{array}{l}\text { passing } \\
\mathrm{PH \# 2} \\
\text { after } \\
\text { coming } \\
\text { from }\end{array}$ & $\begin{array}{l}\text { passing } \\
\text { PH\#2 } \\
\text { after } \\
\text { coming } \\
\text { from }\end{array}$ & $\begin{array}{l}\text { passing } \\
\text { PH\#2 } \\
\text { after } \\
\text { coming } \\
\text { from }\end{array}$ & $\begin{array}{l}\text { passing } \\
\mathrm{PH \# 3} \\
\text { after } \\
\text { coming } \\
\text { from }\end{array}$ & $\begin{array}{l}\text { passing } \\
\text { PH\#3 } \\
\text { after } \\
\text { coming } \\
\text { from }\end{array}$ & $\begin{array}{l}\text { passing } \\
\text { PH\#3 } \\
\text { after } \\
\text { coming } \\
\text { from }\end{array}$ & $\begin{array}{l}\text { passi } \\
\text { comir }\end{array}$ & $\begin{array}{l}\text { spil } \\
\text { from }\end{array}$ & $\begin{array}{l}y \text { afte } \\
\text { H\#3 }\end{array}$ & & $\begin{array}{l}\text { passi } \\
\text { comir }\end{array}$ & g spil & $\begin{array}{l}\text { y after } \\
\text { rebay }\end{array}$ & \\
\hline & & & & & & & & & & $\frac{\text { TSW }}{\underline{22}}$ & $\frac{T S V}{\underline{\text { TSO }}}$ & Bays & $\frac{\text { TSW }}{\underline{4}}$ & $\frac{\text { TSW }}{\underline{22}}$ & $\frac{\text { TSV }}{\underline{20}}$ & Bays & $\frac{\text { TSW }}{\underline{4}}$ \\
\hline $\mathrm{YCH}$ & $*$ & NA & $*$ & $*$ & NA & $*$ & $*$ & NA & $*$ & 1 & 1 & $*$ & 1 & 1 & 1 & $98^{\mathrm{a}}$ & 1 \\
\hline STH & $0^{\mathrm{c}}$ & NA & $24^{\mathrm{c}}$ & $8^{c}$ & NA & $5^{b}$ & $4^{b}$ & NA & $14^{\mathrm{c}}$ & 1 & 1 & $74^{c}$ & 1 & 1 & 1 & $53^{\mathrm{b}}$ & 1 \\
\hline $\mathrm{SCH}$ & $*$ & NA & $20^{\mathrm{c}}$ & $7^{\mathrm{c}}$ & NA & $5^{c}$ & $0^{\mathrm{c}}$ & NA & $0^{\mathrm{c}}$ & 1 & 1 & $*$ & 1 & 1 & 1 & $54^{\mathrm{c}}$ & 1 \\
\hline SOC & $*$ & NA & $*$ & $*$ & NA & $*$ & $*$ & NA & $*$ & 1 & 1 & $*$ & 1 & 1 & 1 & $*$ & 1 \\
\hline
\end{tabular}


Table E3. Percentage of fish passing McNary Dam during day period in 2007 based on a two-step Markov Chain analysis.

[Data represent all fish that first approached the spillway during the day period. Species: YCH, Yearling Chinook salmon; STH, juvenile steelhead; SCH, subyearling Chinook salmon; SOC, Sockeye salmon. Area of Passage: PH\#1, turbine units 1-5; PH\#2, turbine units 6-10; PH\#3, turbine units 11-14; Spillway, spill bays 1-22; Service Bay, equipment service bay on the south end of powerhouse; TSW, temporary spillway weir; ( ) denotes the TSW was not installed; Superscripts denote number of transitions used to calculate percentage: a, greater than 100; b , 50-100; c , 10 to 50; $\left({ }^{*}\right)$, less than 10, which was insufficient sample size to calculate percentage]

\begin{tabular}{|c|c|c|c|c|c|c|c|c|c|c|c|c|c|c|c|c|c|}
\hline $\begin{array}{c}\text { Area of } \\
\text { Passage: }\end{array}$ & \multicolumn{3}{|c|}{$\mathrm{PH} \# 1$} & \multicolumn{3}{|c|}{$\mathrm{PH} \# 2$} & \multicolumn{3}{|c|}{$\mathrm{PH} \# 3$} & \multicolumn{8}{|c|}{ Spillway } \\
\hline \multirow[b]{2}{*}{ Species } & $\begin{array}{l}\text { passing } \\
\text { PH\#1 } \\
\text { after } \\
\text { coming } \\
\text { from }\end{array}$ & $\begin{array}{l}\text { passing } \\
\text { PH\#1 } \\
\text { after } \\
\text { coming } \\
\text { from }\end{array}$ & $\begin{array}{l}\text { passing } \\
\text { PH\#1 } \\
\text { after } \\
\text { coming } \\
\text { from }\end{array}$ & $\begin{array}{l}\text { passing } \\
\text { PH\#2 } \\
\text { after } \\
\text { coming } \\
\text { from }\end{array}$ & $\begin{array}{l}\text { passing } \\
\text { PH\#2 } \\
\text { after } \\
\text { coming } \\
\text { from }\end{array}$ & $\begin{array}{l}\text { passing } \\
\text { PH\#2 } \\
\text { after } \\
\text { coming } \\
\text { from }\end{array}$ & $\begin{array}{l}\text { passing } \\
\text { PH\#3 } \\
\text { after } \\
\text { coming } \\
\text { from }\end{array}$ & $\begin{array}{l}\text { passing } \\
\text { PH\#3 } \\
\text { after } \\
\text { coming } \\
\text { from }\end{array}$ & $\begin{array}{l}\text { passing } \\
\text { PH\#3 } \\
\text { after } \\
\text { coming } \\
\text { from }\end{array}$ & $\begin{array}{l}\text { passir } \\
\text { comir }\end{array}$ & $\begin{array}{l}\text { spillwa } \\
\text { from } F\end{array}$ & $\begin{array}{l}\text { after } \\
\text { \#3 }\end{array}$ & & $\begin{array}{l}\text { passin } \\
\text { comin }\end{array}$ & $\begin{array}{l}\text { spillwe } \\
\text { from fo }\end{array}$ & $\begin{array}{l}\text { after } \\
\text { ebay }\end{array}$ & \\
\hline & & & & & & & & & & $\frac{\text { TSW }}{\underline{22}}$ & $\frac{\text { TSW }}{\underline{20}}$ & Bays & $\frac{\text { TSW }}{\underline{4}}$ & $\frac{\text { TSW }}{\underline{22}}$ & $\frac{\text { TSW }}{\underline{20}}$ & Bays & $\frac{\text { TSW }}{\underline{4}}$ \\
\hline $\mathrm{YCH}$ & * & NA & * & * & NA & $47^{\mathrm{c}}$ & $*$ & NA & $21^{\mathrm{c}}$ & $67^{\mathrm{c}}$ & $8^{c}$ & $8^{c}$ & 1 & $11^{\mathrm{a}}$ & $16^{\mathrm{a}}$ & $62^{\mathrm{a}}$ & 1 \\
\hline STH & $24^{\mathrm{c}}$ & NA & $3^{c}$ & $0^{\mathrm{c}}$ & NA & $2^{b}$ & $2^{c}$ & NA & $2^{b}$ & $58^{\mathrm{b}}$ & $10^{\mathrm{b}}$ & $6^{\mathrm{b}}$ & 1 & $19^{\mathrm{a}}$ & $34^{\mathrm{a}}$ & $25^{\mathrm{a}}$ & 1 \\
\hline $\mathrm{SCH}$ & $*$ & NA & * & $*$ & NA & $21^{\mathrm{c}}$ & $*$ & NA & $17^{\mathrm{c}}$ & $*$ & $*$ & $*$ & 1 & $17^{\mathrm{b}}$ & $28^{\mathrm{b}}$ & $36^{\mathrm{b}}$ & 1 \\
\hline SOC & $*$ & NA & * & * & NA & $*$ & * & NA & $58^{\mathrm{c}}$ & * & $*$ & * & 1 & $11^{\mathrm{c}}$ & $21^{\mathrm{c}}$ & $5^{c}$ & 1 \\
\hline
\end{tabular}


Table E4. Percentage of fish passing McNary Dam during night period in 2007 based on a two-step Markov Chain analysis.

[Data represent all fish that first approached the spillway during the night period. Species: YCH, Yearling Chinook salmon; STH, juvenile steelhead; SCH, subyearling Chinook salmon; SOC, Sockeye salmon. Area of Passage: PH\#1, turbine units 1-5; PH\#2, turbine units 6-10; PH\#3, turbine units 11-14; Spillway, spill bays 1-22; Service Bay, equipment service bay on the south end of powerhouse; TSW, temporary spillway weir; () denotes the TSW was not installed; Superscripts denote number of transitions used to calculate percentage: a, greater than $100 ; \mathrm{b}, 50-100 ; \mathrm{c}, 10$ to 50 ; (*), less than 10, which was insufficient sample size to calculate percentage]

\begin{tabular}{|c|c|c|c|c|c|c|c|c|c|c|c|c|c|c|c|c|c|}
\hline $\begin{array}{c}\text { Area of } \\
\text { Passage: }\end{array}$ & \multicolumn{3}{|c|}{$\mathrm{PH} \# 1$} & \multicolumn{3}{|c|}{$\mathrm{PH} \# 2$} & \multicolumn{3}{|c|}{$\mathrm{PH} \# 3$} & \multicolumn{8}{|c|}{ Spillway } \\
\hline \multirow[b]{2}{*}{$\underline{\text { Species }}$} & $\begin{array}{l}\text { passing } \\
\text { PH\#1 } \\
\text { after } \\
\text { coming } \\
\text { from }\end{array}$ & $\begin{array}{l}\text { passing } \\
\text { PH\#1 } \\
\text { after } \\
\text { coming } \\
\text { from }\end{array}$ & $\begin{array}{l}\text { passing } \\
\text { PH\#1 } \\
\text { after } \\
\text { coming } \\
\text { from }\end{array}$ & $\begin{array}{l}\text { passing } \\
\mathrm{PH} 22 \\
\text { after } \\
\text { coming } \\
\text { from }\end{array}$ & $\begin{array}{l}\text { passing } \\
\text { PH\#2 } \\
\text { after } \\
\text { coming } \\
\text { from }\end{array}$ & $\begin{array}{l}\text { passing } \\
\text { PH\#2 } \\
\text { after } \\
\text { coming } \\
\text { from }\end{array}$ & $\begin{array}{l}\text { passing } \\
\text { PH\#3 } \\
\text { after } \\
\text { coming } \\
\text { from }\end{array}$ & $\begin{array}{l}\text { passing } \\
\text { PH\#3 } \\
\text { after } \\
\text { coming } \\
\text { from }\end{array}$ & $\begin{array}{l}\text { passing } \\
\text { PH\#3 } \\
\text { after } \\
\text { coming } \\
\text { from }\end{array}$ & \multicolumn{4}{|c|}{$\begin{array}{l}\text { passing spillway after } \\
\text { coming from } \mathrm{PH \# 3}\end{array}$} & \multicolumn{4}{|c|}{$\begin{array}{l}\text { passing spillway after } \\
\text { coming from forebay }\end{array}$} \\
\hline & & & & & & & & & & $\frac{\text { TSW }}{\underline{22}}$ & $\frac{\text { TSW }}{\underline{20}}$ & Bays & $\frac{\text { TSW }}{\underline{4}}$ & $\frac{\text { TSW }}{\underline{22}}$ & $\frac{\text { TSW }}{\underline{20}}$ & Bays & $\frac{\text { TSW }}{\underline{4}}$ \\
\hline $\mathrm{YCH}$ & $*$ & NA & $*$ & $*$ & NA & $30^{\mathrm{c}}$ & $*$ & NA & $32^{c}$ & $*$ & $*$ & $*$ & 1 & $17^{\mathrm{a}}$ & $17^{\mathrm{a}}$ & $50^{\mathrm{a}}$ & 1 \\
\hline STH & $6^{\mathrm{c}}$ & NA & $5^{\mathrm{b}}$ & $8^{\mathrm{b}}$ & NA & $9^{b}$ & $8^{c}$ & NA & $3^{c}$ & $65^{\mathrm{c}}$ & $15^{\mathrm{c}}$ & $10^{\mathrm{c}}$ & 1 & $16^{\mathrm{b}}$ & $12^{\mathrm{b}}$ & $30^{\mathrm{b}}$ & 1 \\
\hline $\mathrm{SCH}$ & $*$ & NA & $6^{\mathrm{c}}$ & $7^{\mathrm{c}}$ & NA & $*$ & $*$ & NA & $12^{\mathrm{c}}$ & $*$ & $*$ & $*$ & 1 & $27^{\mathrm{b}}$ & $27^{\mathrm{b}}$ & $27^{\mathrm{b}}$ & 1 \\
\hline SOC & $*$ & NA & $*$ & $*$ & NA & $*$ & $*$ & NA & $*$ & $*$ & $*$ & $*$ & 1 & $25^{\mathrm{c}}$ & $19^{c}$ & $13^{c}$ & 1 \\
\hline
\end{tabular}


Table E5. Percentage of fish passing McNary Dam during day period in 2008 based on a two-step Markov Chain analysis.

[Data represent all fish that first approached the spillway during the day period. Species: YCH, Yearling Chinook salmon; STH, juvenile steelhead; SCH, subyearling Chinook salmon; SOC, Sockeye salmon. Area of Passage: PH\#1, turbine units 1-5; PH\#2, turbine units 6-10; PH\#3, turbine units 11-14; Spillway, spill bays 1-22; Service Bay, equipment service bay on the south end of powerhouse; TSW, temporary spillway weir; ( ) denotes the TSW was not installed; Superscripts denote number of transitions used to calculate percentage: a, greater than 100; b ,50-100; c, 10 to 50; $(*)$, less than 10, which was insufficient sample size to calculate percentage]

\begin{tabular}{|c|c|c|c|c|c|c|c|c|c|c|c|c|c|c|c|c|c|}
\hline $\begin{array}{c}\text { Area of } \\
\text { Passage: }\end{array}$ & \multicolumn{3}{|c|}{$\mathrm{PH} \# 1$} & \multicolumn{3}{|c|}{$\mathrm{PH} \# 2$} & \multicolumn{3}{|c|}{$\mathrm{PH} \# 3$} & \multicolumn{8}{|c|}{ Spillway } \\
\hline \multirow[b]{2}{*}{$\underline{\text { Species }}$} & $\begin{array}{l}\text { passin } \\
\mathrm{g} \mathrm{PH \# 1} \\
\text { after } \\
\text { coming } \\
\text { from }\end{array}$ & $\begin{array}{l}\text { passin } \\
\text { g PH\#1 } \\
\text { after } \\
\text { coming } \\
\text { from }\end{array}$ & $\begin{array}{l}\text { passin } \\
\text { g PH\#1 } \\
\text { after } \\
\text { coming } \\
\text { from }\end{array}$ & $\begin{array}{l}\text { passin } \\
\mathrm{g} \mathrm{PH \# 2} \\
\text { after } \\
\text { coming } \\
\text { from }\end{array}$ & $\begin{array}{l}\text { passin } \\
\mathrm{g} \mathrm{PH \# 2} \\
\text { after } \\
\text { coming } \\
\text { from }\end{array}$ & $\begin{array}{l}\text { passin } \\
\text { g PH\#2 } \\
\text { after } \\
\text { coming } \\
\text { from }\end{array}$ & $\begin{array}{l}\text { passin } \\
\text { g PH\#3 } \\
\text { after } \\
\text { coming } \\
\text { from }\end{array}$ & $\begin{array}{l}\text { passin } \\
\mathrm{g} P H \# 3 \\
\text { after } \\
\text { coming } \\
\text { from }\end{array}$ & $\begin{array}{l}\text { passing } \\
\text { PH\#3 } \\
\text { after } \\
\text { coming } \\
\text { from }\end{array}$ & \multicolumn{4}{|c|}{$\begin{array}{l}\text { passing spillway after } \\
\text { coming from } \mathrm{PH \# 3}\end{array}$} & \multicolumn{4}{|c|}{$\begin{array}{l}\text { passing spillway after } \\
\text { coming from forebay }\end{array}$} \\
\hline & & & & & & & & & & $\frac{\text { TSW }}{\underline{20}}$ & $\begin{array}{l}\frac{\mathrm{TS}}{\mathrm{W}} \\
\underline{19}\end{array}$ & Bays & $\frac{\mathrm{TS}}{\mathrm{W} 4}$ & $\frac{\text { TSW }}{\underline{20}}$ & $\frac{\text { TSW }}{\underline{19}}$ & Bays & $\frac{\mathrm{TS}}{\mathrm{W} 4}$ \\
\hline $\mathrm{YCH}$ & $*$ & NA & $0^{c}$ & $18^{\mathrm{c}}$ & NA & $6^{\mathrm{c}}$ & $25^{\mathrm{c}}$ & NA & $32^{\mathrm{c}}$ & $18^{\mathrm{c}}$ & $9^{c}$ & $27^{\mathrm{c}}$ & 1 & $15^{\mathrm{b}}$ & $31^{\mathrm{b}}$ & $32^{b}$ & 1 \\
\hline STH & $*$ & NA & $0^{\mathrm{c}}$ & $0^{\mathrm{c}}$ & NA & $0^{\mathrm{c}}$ & $4^{c}$ & NA & $5^{\mathrm{c}}$ & $35^{\mathrm{c}}$ & $22^{\mathrm{c}}$ & $19^{c}$ & 1 & $12^{\mathrm{b}}$ & $24^{\mathrm{b}}$ & $20^{\mathrm{b}}$ & 1 \\
\hline $\mathrm{SCH}$ & $8^{c}$ & NA & $0^{\mathrm{c}}$ & $0^{\mathrm{c}}$ & NA & $0^{\mathrm{c}}$ & $10^{\mathrm{c}}$ & NA & $29^{c}$ & $25^{\mathrm{c}}$ & $8^{c}$ & $42^{c}$ & 1 & $18^{\mathrm{b}}$ & $18^{\mathrm{b}}$ & $36^{\mathrm{b}}$ & 1 \\
\hline SOC & $*$ & NA & $*$ & $*$ & NA & $*$ & $*$ & NA & $*$ & $*$ & $*$ & $*$ & 1 & $*$ & $*$ & $*$ & 1 \\
\hline
\end{tabular}


Table E6. Percentage of fish passing McNary Dam during night period in 2008 based on a two-step Markov Chain analysis.

[Data represent all fish that first approached the spillway during the night period. Species: YCH, Yearling Chinook salmon; STH, juvenile steelhead; SCH, subyearling Chinook salmon; SOC, Sockeye salmon. Area of Passage: PH\#1, turbine units 1-5; PH\#2, turbine units 6-10; PH\#3, turbine units 11-14; Spillway, spill bays 1-22; Service Bay, equipment service bay on the south end of powerhouse; TSW, temporary spillway weir; ( () denotes the TSW was not installed; Superscripts denote number of transitions used to calculate percentage: a, greater than 100; b , 50-100; c , 10 to 50; (*), less than 10, which was insufficient sample size to calculate percentage]

\begin{tabular}{|c|c|c|c|c|c|c|c|c|c|c|c|c|c|c|c|c|c|}
\hline $\begin{array}{c}\text { Area of } \\
\text { Passage: }\end{array}$ & \multicolumn{3}{|c|}{$\mathrm{PH} \# 1$} & \multicolumn{3}{|c|}{ PH \#2 } & \multicolumn{3}{|c|}{$\mathrm{PH} \# 3$} & \multicolumn{8}{|c|}{ Spillway } \\
\hline \multirow[b]{2}{*}{$\underline{\text { Species }}$} & $\begin{array}{l}\text { passing } \\
\text { PH\#1 } \\
\text { after } \\
\text { coming } \\
\text { from }\end{array}$ & $\begin{array}{l}\text { passing } \\
\text { PH\#1 } \\
\text { after } \\
\text { coming } \\
\text { from }\end{array}$ & $\begin{array}{l}\text { passing } \\
\text { PH\#1 } \\
\text { after } \\
\text { coming } \\
\text { from }\end{array}$ & $\begin{array}{l}\text { passing } \\
\text { PH\#2 } \\
\text { after } \\
\text { coming } \\
\text { from }\end{array}$ & $\begin{array}{l}\text { passing } \\
\text { PH\#2 } \\
\text { after } \\
\text { coming } \\
\text { from }\end{array}$ & $\begin{array}{l}\text { passing } \\
\text { PH\#2 } \\
\text { after } \\
\text { coming } \\
\text { from }\end{array}$ & $\begin{array}{l}\text { passing } \\
\text { PH\#3 } \\
\text { after } \\
\text { coming } \\
\text { from }\end{array}$ & $\begin{array}{l}\text { passing } \\
\text { PH\#3 } \\
\text { after } \\
\text { coming } \\
\text { from }\end{array}$ & $\begin{array}{l}\text { passing } \\
\text { PH\#3 } \\
\text { after } \\
\text { coming } \\
\text { from }\end{array}$ & $\begin{array}{l}\text { passir } \\
\text { comin }\end{array}$ & $\begin{array}{l}\text { spillwa } \\
\text { from } P\end{array}$ & $\begin{array}{l}\text { after } \\
\text { \#3 }\end{array}$ & & $\begin{array}{l}\text { passin } \\
\text { comin }\end{array}$ & $\begin{array}{l}\text { spillwe } \\
\text { from fo }\end{array}$ & $\begin{array}{l}\text { after } \\
\text { ebay }\end{array}$ & \\
\hline & & & & & & & & & & $\frac{\text { TSW }}{\underline{20}}$ & $\frac{\text { TSW }}{\underline{19}}$ & Bays & $\frac{\text { TSW }}{\underline{4}}$ & $\frac{\text { TSW }}{\underline{20}}$ & $\frac{\text { TSW }}{\underline{19}}$ & Bays & $\frac{\text { TSW }}{\underline{4}}$ \\
\hline $\mathrm{YCH}$ & $*$ & NA & $*$ & $*$ & NA & $*$ & $*$ & NA & $50^{\mathrm{c}}$ & $*$ & $*$ & $*$ & 1 & $9^{c}$ & $27^{\mathrm{c}}$ & $32^{\mathrm{c}}$ & 1 \\
\hline STH & $*$ & NA & $13^{\mathrm{c}}$ & $0^{c}$ & NA & $4^{c}$ & $5^{c}$ & NA & $21^{\mathrm{c}}$ & $20^{\mathrm{c}}$ & $12^{c}$ & $28^{\mathrm{c}}$ & 1 & $7^{\mathrm{b}}$ & $18^{\mathrm{b}}$ & $25^{\mathrm{b}}$ & 1 \\
\hline $\mathrm{SCH}$ & $*$ & NA & $*$ & $*$ & NA & $*$ & $*$ & NA & $25^{\mathrm{c}}$ & $*$ & $*$ & $*$ & 1 & $18^{\mathrm{c}}$ & $26^{\mathrm{c}}$ & $24^{\mathrm{c}}$ & 1 \\
\hline SOC & $*$ & NA & $*$ & $*$ & NA & $*$ & $*$ & NA & $*$ & $*$ & $*$ & $*$ & 1 & $*$ & $*$ & $*$ & 1 \\
\hline
\end{tabular}


Table E7. Percentage of fish passing McNary Dam during day period in 2009 based on a two-step Markov Chain analysis.

[Data represent all fish that first approached the spillway during the day period. Species: YCH, Yearling Chinook salmon; STH, juvenile steelhead; SCH, subyearling Chinook salmon; SOC, Sockeye salmon. Area of Passage: PH\#1, turbine units 1-5; PH\#2, turbine units 6-10; PH\#3, turbine units 11-14; Spillway, spill bays 1-22; Service Bay, equipment service bay on the south end of powerhouse; TSW, temporary spillway weir; ( () denotes the TSW was not installed; Superscripts denote number of transitions used to calculate percentage: a, greater than $100 ; \mathrm{b}, 50-100 ; \mathrm{c}, 10$ to $50 ;(*)$, less than 10 , which was insufficient sample size to calculate percentage]

\begin{tabular}{|c|c|c|c|c|c|c|c|c|c|c|c|c|c|c|c|c|c|}
\hline $\begin{array}{c}\text { Area of } \\
\text { Passage: }\end{array}$ & \multicolumn{3}{|c|}{$\mathrm{PH} \# 1$} & \multicolumn{3}{|c|}{$\mathrm{PH} \# 2$} & \multicolumn{3}{|c|}{$\mathrm{PH} \# 3$} & \multicolumn{8}{|c|}{ Spillway } \\
\hline \multirow[b]{2}{*}{ Species } & $\begin{array}{l}\text { passing } \\
\text { PH\#1 } \\
\text { after } \\
\text { coming } \\
\text { from }\end{array}$ & $\begin{array}{l}\text { passing } \\
\text { PH\#1 } \\
\text { after } \\
\text { coming } \\
\text { from }\end{array}$ & $\begin{array}{l}\text { passing } \\
\text { PH\#1 } \\
\text { after } \\
\text { coming } \\
\text { from }\end{array}$ & $\begin{array}{l}\text { passing } \\
\text { PH\#2 } \\
\text { after } \\
\text { coming } \\
\text { from }\end{array}$ & $\begin{array}{l}\text { passing } \\
\text { PH\#2 } \\
\text { after } \\
\text { coming } \\
\text { from }\end{array}$ & $\begin{array}{l}\text { passing } \\
\text { PH\#2 } \\
\text { after } \\
\text { coming } \\
\text { from }\end{array}$ & $\begin{array}{l}\text { passing } \\
\text { PH\#3 } \\
\text { after } \\
\text { coming } \\
\text { from }\end{array}$ & $\begin{array}{l}\text { passing } \\
\text { PH\#3 } \\
\text { after } \\
\text { coming } \\
\text { from }\end{array}$ & $\begin{array}{l}\text { passing } \\
\text { PH\#3 } \\
\text { after } \\
\text { coming } \\
\text { from }\end{array}$ & $\begin{array}{l}\text { passi } \\
\text { comir }\end{array}$ & $\begin{array}{l}\text { spillw } \\
\text { from } F\end{array}$ & $\begin{array}{l}y \text { after } \\
\text { H\#3 }\end{array}$ & & $\begin{array}{l}\text { passir } \\
\text { comin }\end{array}$ & $\begin{array}{l}\text { spilly } \\
\text { from } f\end{array}$ & $\begin{array}{l}\text { y after } \\
\text { rebay }\end{array}$ & \\
\hline & & & & & & & & & & $\frac{\text { TSW }}{\underline{20}}$ & $\frac{\text { TSW }}{\underline{19}}$ & Bays & $\frac{\text { TSW }}{\underline{4}}$ & $\frac{\text { TSW }}{\underline{20}}$ & $\frac{\text { TSW }}{\underline{19}}$ & Bays & $\frac{\mathrm{TSW}}{\underline{4}}$ \\
\hline $\mathrm{YCH}$ & $*$ & NA & $23^{c}$ & $10^{\mathrm{c}}$ & NA & $28^{\mathrm{c}}$ & $44^{\mathrm{c}}$ & NA & $25^{\mathrm{c}}$ & $*$ & 1 & $*$ & $*$ & $12^{\mathrm{a}}$ & 1 & $65^{\mathrm{a}}$ & $7^{\mathrm{a}}$ \\
\hline STH & $0^{\mathrm{c}}$ & NA & $15^{\mathrm{c}}$ & $7^{\mathrm{c}}$ & NA & $11^{\mathrm{c}}$ & $6^{\mathrm{c}}$ & NA & $17^{\mathrm{c}}$ & $62^{c}$ & 1 & $12^{\mathrm{c}}$ & $0^{\mathrm{c}}$ & $22^{\mathrm{a}}$ & 1 & $36^{\mathrm{a}}$ & $18^{\mathrm{a}}$ \\
\hline $\mathrm{SCH}$ & $*$ & NA & $*$ & $*$ & NA & $10^{\mathrm{c}}$ & $11^{\mathrm{c}}$ & NA & $23^{\mathrm{c}}$ & $23^{\mathrm{c}}$ & $8^{\mathrm{c}}$ & $69^{c}$ & 1 & $11^{\mathrm{a}}$ & $22^{\mathrm{a}}$ & $58^{\mathrm{a}}$ & 1 \\
\hline $\mathrm{SOC}$ & $*$ & NA & $*$ & $*$ & NA & $25^{\mathrm{c}}$ & $*$ & NA & $*$ & $*$ & 1 & $*$ & $*$ & $22^{\mathrm{a}}$ & 1 & $64^{\mathrm{a}}$ & $11^{\mathrm{a}}$ \\
\hline
\end{tabular}


Table E8. Percentage of fish passing McNary Dam during night period in 2009 based on a two-step Markov Chain analysis.

[Data represent all fish that first approached the spillway during the night period. Species: YCH, Yearling Chinook salmon; STH, juvenile steelhead; SCH, subyearling Chinook salmon; SOC, Sockeye salmon. Area of Passage: PH\#1, turbine units 1-5; PH\#2, turbine units 6-10; PH\#3, turbine units 11-14;

Spillway, spill bays 1-22; Service Bay, equipment service bay on the south end of powerhouse; TSW, temporary spillway weir; ( () denotes the TSW was not installed; Superscripts denote number of transitions used to calculate percentage: a, greater than $100 ; \mathrm{b}, 50-100 ; \mathrm{c}, 10$ to $50 ;(*)$, less than 10, which was insufficient sample size to calculate percentage]

\begin{tabular}{|c|c|c|c|c|c|c|c|c|c|c|c|c|c|c|c|c|c|}
\hline $\begin{array}{c}\text { Area of } \\
\text { Passage: }\end{array}$ & \multicolumn{3}{|c|}{$\mathrm{PH} \# 1$} & \multicolumn{3}{|c|}{$\mathrm{PH} \# 2$} & \multicolumn{3}{|c|}{$\mathrm{PH} \# 3$} & \multicolumn{8}{|c|}{ Spillway } \\
\hline \multirow[b]{2}{*}{ Species } & $\begin{array}{l}\text { passing } \\
\text { PH\#1 } \\
\text { after } \\
\text { coming } \\
\text { from }\end{array}$ & $\begin{array}{l}\text { passing } \\
\text { PH\#1 } \\
\text { after } \\
\text { coming } \\
\text { from }\end{array}$ & $\begin{array}{l}\text { passing } \\
\text { PH\#1 } \\
\text { after } \\
\text { coming } \\
\text { from }\end{array}$ & $\begin{array}{l}\text { passing } \\
\mathrm{PH \# 2} \\
\text { after } \\
\text { coming } \\
\text { from }\end{array}$ & $\begin{array}{l}\text { passing } \\
\text { PH\#2 } \\
\text { after } \\
\text { coming } \\
\text { from }\end{array}$ & $\begin{array}{l}\text { passing } \\
\text { PH\#2 } \\
\text { after } \\
\text { coming } \\
\text { from }\end{array}$ & $\begin{array}{l}\text { passing } \\
\text { PH\#3 } \\
\text { after } \\
\text { coming } \\
\text { from }\end{array}$ & $\begin{array}{l}\text { passing } \\
\text { PH\#3 } \\
\text { after } \\
\text { coming } \\
\text { from }\end{array}$ & $\begin{array}{l}\text { passing } \\
\text { PH\#3 } \\
\text { after } \\
\text { coming } \\
\text { from }\end{array}$ & $\begin{array}{l}\text { passi } \\
\text { comir }\end{array}$ & $\begin{array}{l}\text { spillw } \\
\text { from } F\end{array}$ & $\begin{array}{l}y \text { after } \\
\text { H3 }\end{array}$ & & $\begin{array}{l}\text { passi } \\
\text { comir }\end{array}$ & $\begin{array}{l}\text { spillw } \\
\text { from } f\end{array}$ & $\begin{array}{l}\text { y after } \\
\text { rebay }\end{array}$ & \\
\hline & & & & & & & & & & $\frac{\text { TSW }}{\underline{20}}$ & $\frac{\text { TSW }}{\underline{19}}$ & Bays & $\frac{\text { TSW }}{\underline{4}}$ & $\frac{\text { TSW }}{\underline{20}}$ & $\frac{\text { TSW }}{\underline{19}}$ & Bays & $\frac{\mathrm{TSW}}{\underline{4}}$ \\
\hline $\mathrm{YCH}$ & $*$ & NA & $*$ & $*$ & NA & $*$ & $*$ & NA & $46^{\mathrm{c}}$ & $*$ & 1 & $*$ & $*$ & $12^{\mathrm{a}}$ & 1 & $64^{\mathrm{a}}$ & $9^{\mathrm{a}}$ \\
\hline STH & $10^{\mathrm{c}}$ & NA & $6^{\mathrm{b}}$ & $7^{\mathrm{c}}$ & NA & $5^{b}$ & $17^{\mathrm{b}}$ & NA & $15^{\mathrm{b}}$ & $24^{\mathrm{c}}$ & 1 & $40^{\mathrm{c}}$ & $8^{c}$ & $12^{\mathrm{a}}$ & 1 & $48^{\mathrm{a}}$ & $12^{\mathrm{a}}$ \\
\hline $\mathrm{SCH}$ & $*$ & NA & $*$ & $*$ & NA & $*$ & $*$ & NA & $52^{c}$ & $*$ & $*$ & $*$ & 1 & $10^{\mathrm{a}}$ & $19^{\mathrm{a}}$ & $61^{\mathrm{a}}$ & 1 \\
\hline $\mathrm{SOC}$ & $*$ & NA & $*$ & $*$ & NA & $25^{\mathrm{c}}$ & $*$ & NA & $*$ & $*$ & 1 & $*$ & $*$ & $26^{\mathrm{a}}$ & 1 & $58^{\mathrm{a}}$ & $14^{\mathrm{a}}$ \\
\hline
\end{tabular}


Publishing support provided by the U.S. Geological Survey

Publishing Network, Tacoma Publishing Service Center

For more information concerning the research in this report, contact the Director, Western Fisheries Research Center

U.S. Geological Survey

6505 NE 65th Street

Seattle, WA 98115

http://wfrc.usgs.gov/ 


\section{㞭}

을

을

프

을

3

흫

乌ิ

产.

咅

웋

3

罗

院

온

帝

蛋

흥

$\overline{\bar{z}}$

흘

这 